\title{
ESPACIALIDADES DA
}

VIDA PÚBLICA

NOS ESPAÇOS DA

MOBILIDADE METROPOLITANA

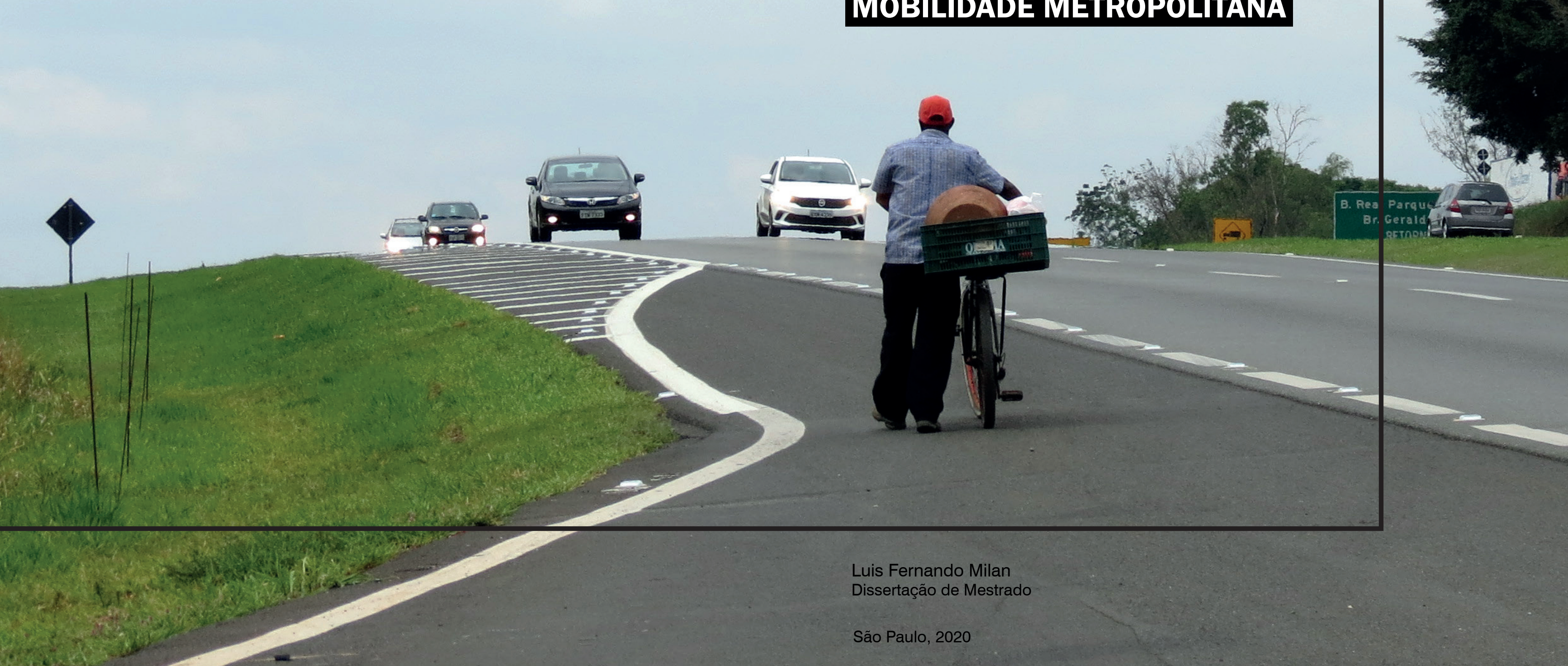




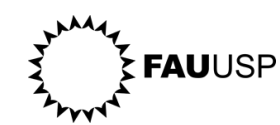

Programa de Pós-Graduação em Arquitetura e Urbanismo

\author{
Luís Fernando Milan
}

\section{ESPACIALIDADES DA VIDA PÚBLICA NOS ESPAÇOS DA MOBILIDADE METROPOLITANA}

Estudo de caso do vetor norte da Região Metropolitana de Campinas: a SP-332

\author{
Dissertação apresentada à Faculdade de Arquitetura e Urbanismo da \\ Universidade de São Paulo para a obtenção do título de Mestre em Arquitetura e \\ Urbanismo. \\ Área de concentração: Paisagem e Ambiente \\ Linha de pesquisa: Paisagem e Sociedade \\ Orientador: Prof. Dr. Fábio Mariz Gonçalves
}

São Paulo 
Faculdade de Arquitetura e Urbanismo da Universidade de São Paulo

Milan, Luis Fernando Espacialidades da vida pública nos espaços da mobilidade
metropolitana: estudo de caso do vetor norte da Região Metropolitana de Campinas, a SP-332/ Luis Fernando Milan; orientador Fábio Mariz Gonçalves. - São Paulo, 2020.

Dissertação (Mestrado) - Faculdade de Arquitetura

Urbanismo da Universidade de são Paulo. Área de
concentração: Paisagem e Ambiente.

1. Mobilidade Urbana. 2. Vida Pública. 3. Região Metropolitana de Campinas. I. Gonçalves, Fábio Mariz, orient. II. Título.

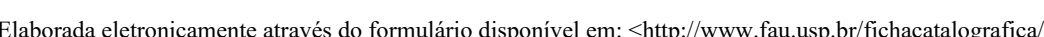


Nome: MILAN, Luís Fernando

Título: Espacialidades da Vida Pública nos Espaços da Mobilidade Metropolitana: Estudo de caso do vetor norte da Região Metropolitana de Campinas: a SP-332

Dissertação apresentada à Faculdade de Arquitetura e Urbanismo da Universidade de São Paulo para a obtenção do título de Mestre em Arquitetura e Urbanismo.

Aprovado em:

Banca Examinadora

Prof. Dr. nstituição:

Julgamento: Assinatura:

Prof. Dr. Instituição:

Julgamento: Assinatura:

Prof. Dr. Instituição:

Julgamento: Assinatura: 


\section{AGRADECIMENTOS}

Ao Prof. Fábio Mariz Gonçalves pela orientação neste trabalho e, principalmente, pela compreensão e sensibilidade ao acolher uma ideia que se mistura muito com minhas experiências pessoais.

Ao Tiago pela paciência, pela ajuda no desembaralhar das ideias e pelas discussões que enriqueceram todo o processo.

À Ana, pela parceria, pela colaboração e pelas sugestões acertadas. À Deborah pela companhia na caminhada.

À Maira pela amizade e dedicação à revisão.

Aos amigos Bia, Sarah, Laís e Leo que estiveram presentes no dia a dia e aos amigos e colegas que indiretamente me deram suporte durante todo o processo.

Ao Henrique e à Ju, que prontamente me abriram caminhos para a construção da cartografia.

E à minha família por todo o apoio, em especial à minha mãe. 
Esta pesquisa tem por objetivo contribuir para os estudos dos processos de metropolização, especialmente na compreensão das formas de habitar as metrópoles contemporâneas, pelo viés dos deslocamentos do homem e das suas formas de vida nos espaços metropolitanos. Para isto, são identificadas e descritas algumas dinâmicas metropolitanas cotidianas pouco evidentes, diante da complexidade do território e do peso dado às relações econômicas, que são fatores preponderantes na estruturação e nos processos de gestão e planejamento das metrópoles, da macrometrópole e da megalópole. A pesquisa busca, assim, caracterizar e analisar as formas urbanas consequentes da ocupação dispersa do território metropolitano, que se desenvolvem em função das rodovias, comuns no interior do Estado de São Paulo. O objeto de estudo é a Região Metropolitana de Campinas, mais especificamente a Rodovia Zefferino Vaz (SP-332) e suas ramificações, classificadas como vias de interesse metropolitano. Dentro deste recorte, são analisadas as relações entre essas vias e as áreas urbanizadas que se formaram próximas às rodovias e estradas vicinais, nas áreas de transição entre áreas rurais e urbanas e fora dos núcleos urbanos consolidados. Os conceitos de mobilidade e permanência são os fios condutores da pesquisa, que busca evidenciar os lugares da vida pública nos espaços de mobilidade em escala metropolitana. Tais conceitos são utilizados nas definições do que são as "ruas" e são, aqui, transportados para a escala da metrópole. As questões que surgem a partir da caracterização dessas dinâmicas e relações estabelecem críticas às formas de tratamento e gestão das vias metropolitanas, como as rodovias, diante das formas de apropriação do espaço metropolitano.

Palavras chave: 1. Mobilidade urbana 2. Vida pública 3. Dispersão urbana 4. Sistema viário metropolitano 5. Região Metropolitana de Campinas
The present research aims to contribute to the studies about the cities metropolization processes, especially about the ways of inhabiting contemporary metropolises, through the study of citizens displacement and their life in metropolitan spaces. For this, some metropolitan everyday dynamics were identified and described, in order to be considered as an additional factor during planning and management processes of metropolises, macro-metropolis and megalopolis, in addition to the most usual factors as the complexity of the territory and economic relations. This research seeks to characterize and analyze urban forms resulted from the urban sprawl occupation process of the metropolitan territory, very common in the countryside of the state of São Paulo, which has its development related to the highways. The object of this study is the Metropolitan Region of Campinas, more specifically the Road Zefferino Vaz (SP-332) and its ramifications, classified as routes of metropolitan interest. Within the area of study, it'll be analyzed the relations between the roads and urbanized areas close to them. These areas were formed between urban and rural areas, far from consolidated urban centers. The concepts of mobility and permanence are the guidelines for this research, which seeks to highlight the places where public life happens in mobility spaces, on metropolitan scale. These concepts are taken to the scale of metropolitan areas and used to define what "streets" are. The issues that arise from the characterization of these dynamics and relations establish criticism of current forms of treatment and management of metropolitan roads, in the face of appropriation of the metropolitan space.

Key words: 1. Urban mobility 2. Public life 3. Urban sprawl 4. Metropolitan road system 5. Campinas Metropolitan Region 


\section{LISTA DE FIGURAS}

Todas as fotografias utilizadas nesta pesquisa são de autoria própria. Para os mapas e tabelas, são indicadas as fontes de dados, ainda que tenham sido elaborados pelo autor.

Figura 1: Vista da Rodovia Zefferino Vaz (SP-332) e os meios de transporte Figura 2: Vista de Barão Geraldo a partir de condomínio em Betel

Figura 3: Vista da Rodovia Zefferino Vaz (SP-332)

Figura 4: Mapa de ações complementares do PITU-RMC 2015

Figura 5: Viagens externas por motivo trabalho e estudo com origem no Centro Metropolitano e destino por vetor de expansão urbana

Figura 6: Mapa da Região Metropolitana de Campinas

Figura 7: Mapa de evolução da mancha urbana da RMC

Figura 8: Tanques de combustível da REPLAN, em Paulínia

Figura 9: Represa e plantação de cana-de-açúcar em Cosmópolis

Figura 10: Mapa de Rodovias da RMC

Figura 11: Mapa dos 8 vetores da RMC

Figura 12: Mapa do Vetor 3 da RMC

Figura 13: Foto aérea do limite de Município entre Paulínia e Cosmópolis

Figura 14: Mapa de Leitura unificada dos Macrozoneamentos e zoneamentos da RMC

Figura 15: Mapa de Uso e Ocupação do Vetor 3 da RMC

Figura 16: Taxas médias de crescimento demográfico por setores censitários - RMC 2010

Figura 17: Principais fluxos de viagens por transporte individual da RMC Figura 18: Principais fluxos de viagens por transporte coletivo da RMC

Figura 19: Ponto de ônibus na SP-332, em Campinas

Figura 20: Mapa de classificação das vias, segundo SIVIM

Figura 21: Pedestre caminha pela rua, dividindo espaço com outros modais

Figura 22: Pedestres caminham pela rua
Figura 23: Passeio próximo ao condomínio

Figura 24: Calçada sem pavimentação

Figura 26: Pedestres caminham em estrada

Figura 25: Pedestres caminham em rodovia

Figura 27: Pedestre em área industrial

Figura 28: Pedestre caminha em calçada na lateral da Rodovia SP-332 Figura 29: Acesso ao ponto de ônibus

Figura 30: Caminho para a escola

Figura 31: Paraciclo próximo ao ponto de ônibus metropolitano

Figura 32: Ciclistas no espaço intraurbano

Figura 33: Ciclistas em via metropolitana

Figura 34: Ciclista em estrada

Figura 36: Ciclista de final de semana

Figura 35: Produtor agrícola pedalando

Figura 37: Trajeto cotidiano na rodovia

Figura 38: Mapa das linhas de ônibus metropolitano da RMC

Figura 39: Mapa das linhas de ônibus metropolitano do Vetor 3

Figura 40: Ônibus metropolitano em espaço intraurbano, em via metropolitana secundária

Figura 41: Ônibus metropolitano em via macrometropolitana

Figura 42: Ônibus escolar circulando pela SP-332, em Paulínia Figura 43: Van fretada, na SP-332, com destino à universidade Figura 44: Ônibus fretado em via do espaço intraurbano

Figura 45: Ônibus fretado utilizando ponto de ônibus metropolitano Figura 46: Ônibus fretado em área industrial, na rodovia SP-332 Figura 47: Ônibus fretado em mesmo trajeto que ônibus metropolitano Figura 48: Treminhão em estrada vicinal

Figura 50: Caminhão petroquímico na SP-332

Figura 49: Caminhão pequeno em avenida

Figura 51: Trem cruzando a SP-332

Figura 52: Congestionamento na Rodovia SP-332

Figura 53: Avenida de Paulínia com estacionamentos ocupados Figura 54: Desembarque de carona na SP-332 
Figura 55: Motociclista na SP-332

Figura 56: Mapa de localização dos condomínios e loteamentos residenciais fechados

Figura 57: Foto aérea de condomínio em Paulínia

Figura 58: Lateral do Condomínio Rio das Pedras na Estrada da Rhodia

Figura 59: Conjunto de condomínios em Betel

Figura 60: Solução para calçadas

Figura 61: Condomínio em área urbana

Figura 62: Condomínio de alto padrão em Engenheiro Coelho

Figura 63: Condomínio em Cosmópolis

Figura 64: Condomínio em Artur Nogueira

Figura 65: Crescimento da ocupação residencial nas vias metropolitanas

Figura 66: Mapa de localização das áreas residenciais

Figura 67: Foto aérea da dispersão urbana em Cosmópolis

Figura 68: Loteamento residencial em área dispersa em Artur Nogueira

Figura 69: Loteamento residencial em Paulínia

Figura 70: Ocupação residencial em Cosmópolis

Figura 71: Verticalização em Paulínia

Figura 72: Relação de residencial com rodovia

Figura 73: Inserção da verticalização

Figura 74: Mapa de localização das atividades comerciais e de prestação de serviços

Figura 75: Borracharias na SP-332

Figura 76: Loja de piscinas na SP-332

Figura 77: Pátio de recolha de veículos

Figura 78: Motel em Barão Geraldo

Figura 79: Motel em via metropolitana

Figura 81: Comércio próximo aos condomínios

Figura 80: Padaria na Estrada da Rhodia

Figura 82: Banca de frutas na Estrada da Rhodia

Figura 83: Restaurante na Estrada da Rhodia

Figura 85: Comércio informal estratégico na via marginal à SP-332

Figura 84: Comércio em via metropolitana
Figura 86: Imagem aérea da REPLAN, em Paulínia

Figura 87: Mapa de localização das indústrias

Figura 88: Distrito industrial de Paulínia

Figura 89: Passarela e grande indústria

Figura 90: Área industrial de Artur Nogueira

Figura 91: Indústrias de pequeno porte

Figura 93: Imagem áerea da área de implantação da UNASP, em Engenheiro

$$
\text { Coelho }
$$

Figura 92: Sambódromo em avenida de Paulínia

Figura 94: Loteamentos de chácaras em Cosmópolis

Figura 95: Chácaras sem acesso direto à rodovia

Figura 96: Chácaras com acesso à rodovia

Figura 97: Mapa de localização dos loteamentos irregulares

Figura 98: Loteamento irregular em Artur Nogueira

Figura 99: Loteamento irregular próximo ao distrito de Betel

Figura 100: O condomínio e a plantação

Figura 102: Área de produção agrícola familiar em Paulínia

Figura 101: Plantação de hortaliças em Barão Geraldo

Figura 103: Área de produção agrícola com área urbana ao fundo

Figura 104: Área urbana com área de produção agrícola ao fundo

Figura 105: Mapa de localização dos pontos de ônibus metropolitano da SP-332

Figura 106: Ponto de ônibus em Campinas

Figura 107: Ponto de ônibus em área industrial

Figura 108: Ponto de ônibus em Paulínia

Figura 109: Ponto de ônibus em Cosmópolis

Figura 110: Ponto de ônibus em Betel

Figura 112: Ponto de ônibus dos condomínios

Figura 111: Acesso precário ao ponto

Figura 113: Ponto de ônibus em estrada

Figura 114: Mapa de localização das travessias da SP-332

Figura 115: Praça de acesso à passarela

Figura 117: Passarela de integração da dispersão 
Figura 116: Acesso precário à passarela

Figura 118: Dispositivo típico de acesso

Figura 119: Passarela em área industrial

Figura 120: Passarela com ocupação unilateral

Figura 121: Passarela em área de uso misto

Figura 122: Travessia da SP-332, em área sem passarela, com pontos de ônibus

Figura 123: Barreiras sob as passarelas

Figura 124: Travessia de ciclistas

Figura 125: Travessia em estradas

Figura 127: Travessia em área urbana

Figura 126: Conflito entre modais

Figura 128: Pessoas caminham em passarela da Rodovia SP-332

Figura 129: Sistema viário na metrópole dispersa

Figura 130: Diferenças de escala na ocupação do território metropolitano

Figura 131: Via macrometropolitana, as rodovias e as relações de uso e ocupação

Figura 132: Via metropolitana secundáris, as ruas e as relações de uso e ocupação

Figura 133: Manchas de ocupação dos pedestres na rodovia

Figura 134: Manchas de ocupação dos pedestres na rua

Figura 135: A brincadeira

Figura 136: O bate papo

Figura 137: A despedida

Figura 138: A conexão

Figura 140: O parque

Figura 139: A praça

Figura 141: As compras

Figura 142: A feira

Figura 143: O passeio

Figura 144: O caminho

Figura 145: Quadro teórico

Figura 146: Esperando no ponto de ônibus

\section{LISTA DE SIGLAS}

$\begin{array}{ll}\text { AGEMCAMP } & \text { Agência Metropolitana de Campinas } \\ \text { CPTM } & \text { Companhia Paulista de Trens Metropolitanos } \\ \text { CTB } & \text { Código de Trânsito Brasileiro } \\ \text { EMPLASA } & \text { Empresa Paulista de Planejamento Metropolitano SA } \\ \text { EMTU } & \text { Empresa Metropolitana de Transportes Urbanos } \\ \text { HCM } & \text { High Capacity Manual } \\ \text { IBGE } & \text { Instituto Brasileiro de Geografia e Estatística } \\ \text { IDE/SP } & \text { Infraestrutura de Dados Espaciais do Estado de São Paulo } \\ \text { PDUI } & \text { Plano de Desenvolvimento Urbano Integrado } \\ \text { PIB } & \text { Produto Interno Bruto } \\ \text { PITU } & \text { Plano Integrado de Transportes Urbanos } \\ \text { PUCC } & \text { Pontifícia Universidade Católica de Campinas } \\ \text { REPLAN } & \text { Refinaria de Paulínia } \\ \text { RMC } & \text { Região Metropolitana de Campinas } \\ \text { RMSP } & \text { Região Metropolitana de São Paulo } \\ \text { SIVIM } & \text { Sistema Viário de Interesse Metropolitano } \\ \text { STM } & \text { Secretaria dos Transportes Metropolitanos } \\ \text { UNASP } & \text { Centro Universitário Adventista de São Paulo } \\ \text { UNICAMP } & \text { Universidade Estadual de Campinas }\end{array}$




\section{SUMÁRIO}

INTRODUÇÃO

1. MOBILIDADE E PERMANÊNCIA NA METRÓPOLE

1.2. METRÓPOLE DISPERSA …….......................................................................

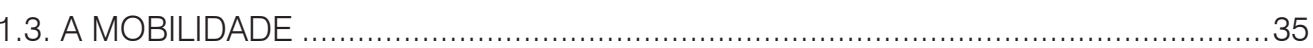

1.4. ESPAÇOS DE VIDA METROPOLITANOS .....................................................39

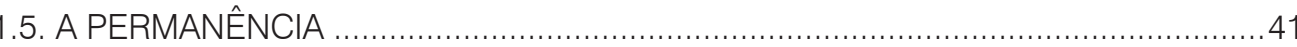

2. A RMC E A MOBILIDADE - A ESCALA METROPOLITANA ................ 49

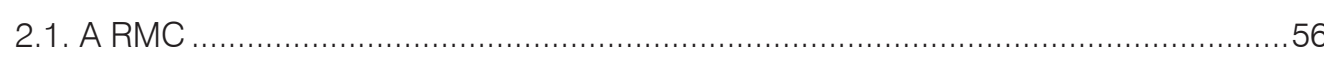

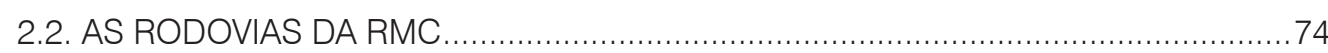

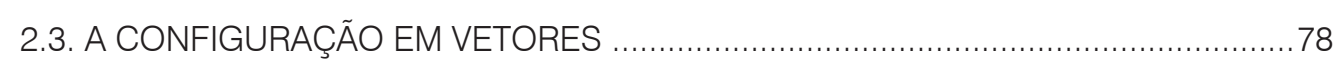

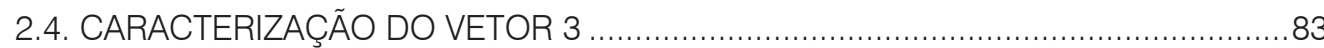

3. LEITURAS E CARACTERIZAÇÃO DO VETOR 3 - ESCALA DO TECIDO URBANO

3.1. A CLASSIFICAÇÃO DAS RODOVIAS...

3.2. A PESQUISA DE CAMPO

3.3. CARACTERIZAÇÃO DO VETOR 3

4. MANIFESTAÇÕES DA VIDA PÚBLICA NO SISTEMA VIÁRIO

METROPOLITANO DO VETOR 3

REFERÊNCIAS 
Assim, a pesquisa estuda as áreas de dispersão urbana, uma vez que este fenômeno gera territórios indefinidos, que aproximam, misturam e sobrepõem os usos urbanos e rurais, as atividades em escala local e regional e as dinâmicas urbanas e metropolitanas, colocando-os em movimento, no mesmo território, ao mesmo tempo. Dessa forma, pretendese identificar formas de habitar a metrópole nestes espaços intersticiais, fora dos núcleos urbanos consolidados, nos quais a vida pública também acontece, seguindo a indicação de Reis (2006, p.151), que aponta que "o estudo das novas configurações do tecido urbano fornece subsídios para a compreensão dos diferentes modos de vida que se desenvolvem nessas áreas".

O interesse, aqui, portanto, não está no espaço intraurbano, mas nos espaços intrametropolitanos, de interação entre as áreas urbanas e rurais, formadas a partir da dispersão urbana e estruturadas, principalmente, pelas rodovias. Ou seja, têm-se como foco as vias de caráter metropolitano, compreendidas não apenas a partir da sua inserção no sistema viário mas considerando todas as relações que se desenvolvem sobre elas e com elas.

A busca pelos espaços da vida pública no sistema viário metropolitano é apresentada em quatro capítulos, descritos a seguir.

No capítulo 1, são feitas as considerações teóricas sobre a metrópole, considerando a mobilidade como fio condutor e a permanência como a questão a ser compreendida, neste contexto. A mobilidade é tratada sob o ponto de vista da dispersão urbana, conforme definida por Nestor Goulart Reis, dada a sua importância, como causa e consequência, na construção da metrópole.

Já a permanência, é compreendida como a representação dos espaços de vida metropolitanos e suas dinâmicas específicas. A complexidade dessas relações da metrópole é, ainda, evidenciada pelo conceito de "homem lento" de Milton Santos, em coexistência com os tempos rápidos, mostrando, ainda, o caráter transescalar das dinâmicas da metrópole.
Diante dessas condições, a questão que se apresenta é onde e como se manifesta a vida pública na metrópole, seja ela em movimento ou na apropriação do espaço pela população.

Na busca por esse reconhecimento, é apresentado, no Capítulo 2, o objeto de estudo deste trabalho, a Região Metropolitana de Campinas, mais especificamente o seu vetor norte, que compreende as cidades de Paulínia Cosmópolis, Artur Nogueira e Engenheiro Coelho. Além da caracterização da região como um todo, são descritas as suas rodovias, os vetores que compõem a região, além de pontuar as principais características do Vetor

Após a caracterização em escala metropolitana, érealizada a caracterização do vetor norte na escala do tecido urbano, no Capítulo 3. A partir das considerações sobre as possibilidades de classificação do sistema viário, fez-se a escolha por trabalhar com as definições do Sistema Viário de Interesse Metropolitano. Foram realizadas análises dos elementos que compõem as vias de caráter metropolitano e suas áreas lindeiras, fora dos núcleos urbanos consolidados, nas áreas de intersecção entre urbano e rural, considerando os movimentos e as permanências que nelas acontecem. Através de levantamento fotográfico, a caracterização se divide em três grupos principais: os meios de transporte, as ocupações e os elementos de integração e transposição dos sistemas de transporte.

Ainda que a consideração desses elementos seja necessária na compreensão das formas de ocupar e de se utilizar da metrópole, não são suficientes para compreender as formas de apropriação efetiva dos espaços. O Capítulo 4 mostra as diversas manifestações da vida pública nas áreas de estudo e levanta questões tanto em relação à aproximação, em termos de ocupações e atividades, entre as vias metropolitanas (representadas pelas rodovias) e as vias urbanas (representadas pela rua) quanto às suas diferenças, principalmente no que se refere aos pactos, regras, desenho e gestão destes espaços. 
CAPÍTULO 1

MOBILIDADE E PERMANÊNCIA NA METRÓPOLE 


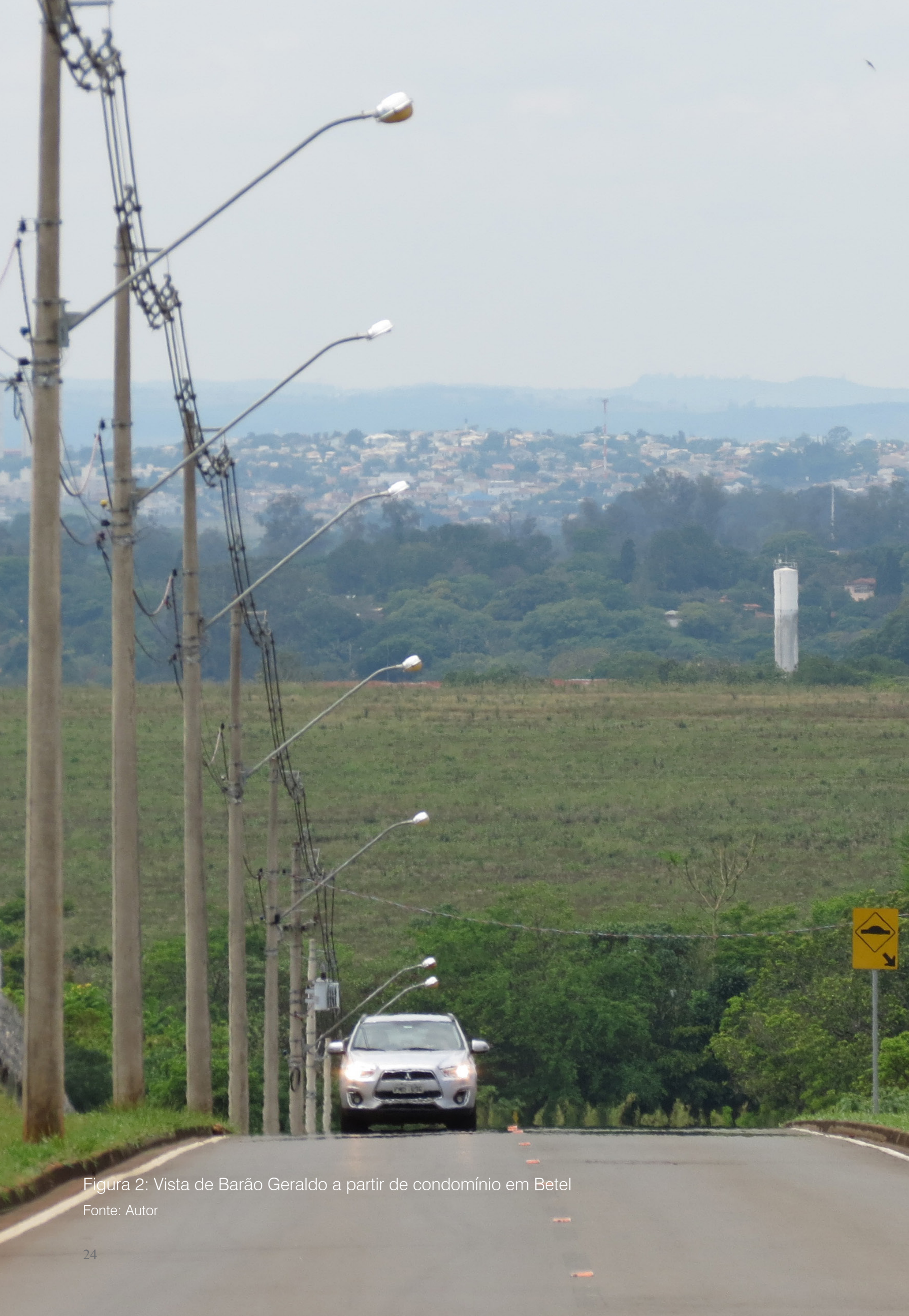

\section{MOBILIDADE E PERMANÊNCIA NA METRÓPOLE}

\subsection{A METRÓPOLE E A REGIÃO METROPOLITANA}

A partir da aceleração do crescimento populacional das cidades brasileiras na década de 1950, as metrópoles passam a ser os principais palcos dinamizadores da vida urbana. Inseridas, como causa e consequência, no meio técnico-científico-informacional, a metropolização pode ser caracterizada por processos concomitantes de concentração e desconcentração, populacionais e econômicos, além de serem os principais polos de difusão cultural, técnica e científica para o território brasileiro, como define Queiroga (2012).

Segundo Milton Santos (1993), o fenômeno da macro-urbanização e da metropolização ganhou importância fundamental nas últimas décadas e apresenta as seguintes características: concentração da população e da pobreza; ao mesmo tempo em que se observa a rarefação rural e a dispersão geográfica das classes médias; e a concentração das atividades relacionais modernas, em conjunto com a dispersão geográfica da produção física.

Diante dessas relações, as metrópoles podem ser definidas lugares complexos, espaços de segregação e conflito, nas quais, segundo Santos (2006) vetores de todas as ordens são entrelaçados pelo espaço comum.

A cidade grande é um enorme espaço banal, o mais significativo dos lugares. Todos os capitais, todos os trabalhos, todas as técnicas e formas de organização podem aí se instalar, conviver, prosperar. (SANTOS, 1996 p.218)

As metrópoles brasileiras cresceram em número, tamanho e importância No final do século XX, muitas cidades têm se tornado sede de regiões 
metropolitanas, que, segundo Queiroga (2012, p. 162), têm "relevância enquanto território urbano em que, via de regra, mais rica é a esfera pública política, devido a seu porte, diversidade e complexidade". A configuração dos territórios em regiões metropolitanas evidencia diferenças estruturais na dinâmica das cidades que as conformam, uma vez que o espaço regional tem características distintas do espaços intraurbano. De acordo com Villaça (2001, p.20):

A estruturação do espaço regional é dominada pelo deslocamento das informações, da energia, do capital constante e das mercadorias em geral - eventualmente até da mercadoria força de trabalho. O espaço intraurbano, ao contrário, é estruturado fundamentalmente pelas condições de deslocamento do ser humano, seja enquanto portador da mercadoria força de trabalho - como no deslocamento casa/trabalho - seja enquanto consumidor - reprodução
da força de trabalho".

Ainda que sejam espaços distintos, com dinâmicas próprias, Reis (2006) indica que as análises dos espaços da metropolização não devem ser pautadas pelas questões regionais, mas pelas questões urbanas, visto que os estes espaços ainda estão diretamente relacionados com as dinâmicas urbanas, eles ainda são cidades. Esta afirmação demonstra que há intersecção de escalas na caracterização das metrópoles e regiões metropolitanas.

Dessa forma, dependendo da forma com que a metrópole é abordada a escala a que se refere pode mudar, conferindo-Ihe caráter multiescalar, dado que, diferentes dinâmicas e relações ocorrem concomitantemente sobre o mesmo território.

Segundo Marandola (2008), o espaço das regiões metropolitanas possui característica não apenas de multiescalaridade, mas, também, de transescalaridade, visto que existe uma transferência de vivências próprias de uma escala para outras. Ou seja, ainda que as relações internas sejam referentes ao intraurbano, diversas são as dinâmicas regionais que influenciam diretamente na configuração da metrópole e vice-versa. As relações internas, cotidianas também são importantes nas dinâmicas regionais e por elas condicionadas.
Para esta pesquisa, reconhecer essa característica de transescalaridade da metrópole é essencial. Na busca pelas relações cotidianas da população que habita a Região Metropolitana de Campinas, é possível reconhecer fatores que se cruzam em situações inesperadas. Dessa forma, Marandola (2008) sugere a classificação do espaço metropolitano como intrametropolitano, ao tratar do seu cotidiano.

\section{A diferença entre intra-urbano, enquanto o espaço da reprodução social e do cotidiano, e regional, o espaço de produção e de trocas (VILLAÇA, 2001) se dilui à medida que os dois se encontram na conformação de um espaço regional de características intraurbanas: intrametropolitano. É este espaço que tem sido vivido pelas pessoas com intensidade cada vez maior, resultando num duplo movimento que precisamos analisar: o que desse modo de vida metropolltano (que éligado ao sistemaglobal) interfere na experiência das pessoas e em que medida as pessoas entram nesse novo sistema, incorporando aos seus modos-de-ser essas interferências. (MARANDOLA 2008, p.96)}

A dispersão urbana tem papel importante nessa configuração do espaço intrametropolitano, já que é através desse processo que as dinâmicas urbanas passam a ser reproduzidas em territórios próprios de outras escalas. Segundo Pires (2007), a expansão urbana tem se caracterizado pelo espraiamento da ocupação urbana, tendo como base empreendimentos imobiliários e de grande porte, o que gera alterações significativas na configuração socioespacial da metrópole. As mudanças principais acontecem tanto na valorização do preço da terra, quanto no aumento da mobilidade da população, por meio do transporte individual o que induz o uso do sistema viário metropolitano para os deslocamentos diários, cotidianos, da população da metrópole, uma vez que está distribuída pelos diversos municípios da metrópole.

Essa condição de dualidade da metrópole, que participa de dinâmicas regionais ao mesmo tempo em que tem suas dinâmicas internas próprias permite que ela seja reconhecida de duas formas diferentes. Segundo Marandola (2008, p.92), o sentido da metrópole pode ser pensado "pela sua materialidade (histórica e geográfica) e pelo papel que desempenha na estruturação do sistema capitalista planetário" ou pelo "modo de vida 
específico, fruto da racionalidade moderna que na metrópole se manifesta de maneira própria", sendo que ambas as formas se "interpenetram e se retroalimentam". Para esta pesquisa, serão investigados os modos de vida específicos da metrópole - modo de vida metropolitano -, ainda que sejam consideradas as relações regionais, de estruturação em maior escala, como forma de compreensão dos processos mais amplos, que influenciam nas questões cotidianas.

Marandola (2008), aponta as metrópoles como centros de comando, a partir das quais acontecem transformações socioespaciais da macroescala, como por exemplo, as inovações tecnológicas, as alterações produtivas, as normas e os estilos de vida. A industrialização, as melhorias dos sistemas de transportes e de comunicação são fatores decisivos para a metropolização, tendo como resultado a integração das diversas regiões com um sistema global-integrado, no qual ocorre uma homogeneização dos estilos de vida, das relações sociais e das pessoas. A tendência portanto, é que o modo de vida metropolitano se torne modelo e traga para o local, o que é característico do global.

Isto posto, a questão que emerge dessa condição é: o que mudou no modo de vida metropolitano, em relação ao modo de vida urbano? Segundo Marandola (2008), Simmel associa a metrópole à intensidade e densidade dos movimentos, à alteração constante, à aceleração do ritmo de vida e à transitoriedade.

"Para Simmel, esses elementos que caracterizam tanto as paisagens quanto os modos de vida e as relaçoees sociais produzem efeitos de origem psíquica que terẫo manifestação nas relações sociais. Ele contrapõe a tranquilidade e continuidade que marca o rural e as cidades menores à velocidade com que as mudanças ocorrem. Tais mudanças não são apenas no tempo, mas também no espaço, já que a concentração e a multiplicidade permitem que tudo esteja na metrópole". (MARANDOLA, 2008, p.94)

Ou seja, as cidades e o rural possuem tempos mais lentos e maior homogeneidade nas relações. Já a metrópole é o lugar das mudanças rápidas, da velocidade e da heterogeneidade das relações. Importante destacar que a diferença não está relacionada apenas no tempo, mas também no espaço, visto que a dimensão física da metrópole é maior que das cidades, impactadas, ainda, pelo fenômeno da dispersão urbana.

Mas é importante ressaltar, aqui, que essa diferença entre tempos e espaços não acontecem de formas separadas, bem delimitadas. Tudo acontece no mesmo espaço, ao mesmo tempo, o que torna a metrópole um território complexo, de dinâmicas que se entrelaçam.

Considerando essa diferença no modo de vida metropolitano em relação ao urbano e que a escala do cotidiano tem como base as próprias cidades, é possível dizer que, na metrópole, as atividades urbanas continuam a existir, sejam elas moradia, trabalho, lazer, compras, mas passam a conviver com outras formas, espaciais e/ou temporais, possíveis pelas tecnologias de comunicação e transporte.

Essa condição dá à metrópole características de unificadora e desagregadora, deslocando o homem do território, do lugar em que vive, uma vez que suas dinâmicas cotidianas parecem estar fora do lugar distribuídas pelo território metropolitano. Segundo Marandola (2008, p.95) a metrópole

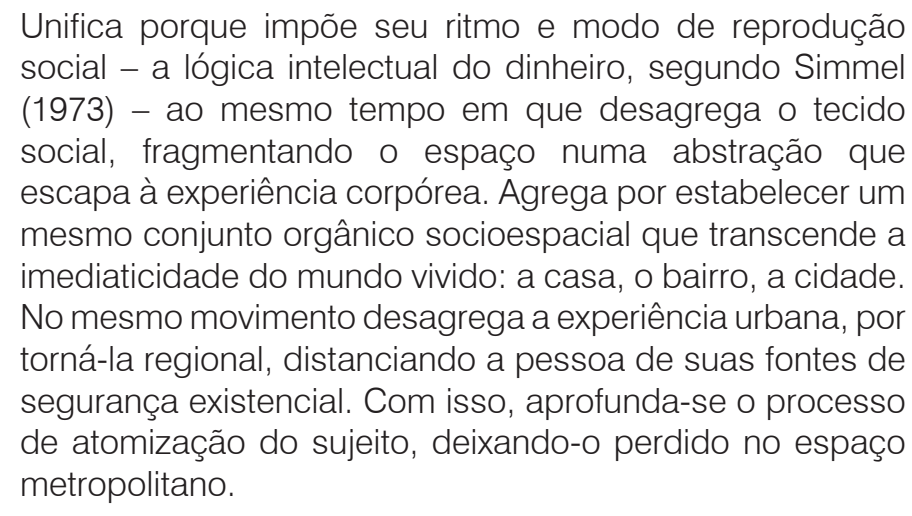

Eéneste contexto, do homem ocupando o espaço intrametropolitano, que o conceito de homem lento, de Milton Santos, faz compreender a importância da mobilidade e da permanência como formas de estudar a metrópole e quem a ocupa, constrói e por ela é influenciado. O intrametropolitano mistura os tempos dos homens no território metropolitana, tornando complexo descrever de apenas uma forma qual o tempo do homem que ele habita. Segundo Milton Santos (2006, p.220), 
Durante séculos, acreditáramos que os homens mais velozes detinham a inteligência do Mundo. A literatura que glorifica a potência incluiu a velocidade como essa força mágica que permitiu à Europa civilizar-se primeiro empurrar, depois, a "sua" civilização para o resto do mundo. Agora, estamos descobrindo que, nas cidades, o tempo que comanda, ou vai comandar, é o tempo dos homens lentos. $\mathrm{Na}$ grande cidade, hoje, o que se dá é tudo ao contrário. A força é dos "lentos" e não dos que detém a velocidade (....). Quem, na cidade, tem mobilidade - e pode percorrê-la e esquadrinhá-la - acaba por ver pouco, da cidade e do mundo. Sua comunhão com as imagens, frequentemente pré-fabricadas, e a sua perdição. Seu conforto, que năo desejam perder, vem, exatamente, do convivio com essas imagens. Os homens "lentos", para quem tais imagens sâo miragens, não podem, por multo tempo, estar em fase com esse imaginário perverso e ir descobrindo as fabulações.

Destaca-se, assim, a segregação espacial e temporal na metrópole, entre os diversos grupos que a habitam. $\mathrm{O}$ acesso à mobilidade e aos diferentes tipos de mobilidade define a condição das pessoas inseridas no contexto metropolitano, ora envolvidas nas dinâmicas do tempo rápido, ora impostas ao tempo lento

Assim, para esta pesquisa, a metrópole se apresenta como território complexo, de dinâmicas heterogêneas e caráter transescalar, no qual a mobilidade e a permanência do homem que a ocupa denunciam novas formas de pensar e viver o urbano. Aqui, as rodovias se apresentam como espaços comuns, livres, o lugar do homem lento, mas o espaço de realização do homem rápido.

\subsection{METRÓPOLE DISPERSA}

Para compreender o papel da mobilidade na estruturação das metrópoles, é preciso tratar da dispersão urbana como um fenômeno que a tem como sua principal aliada na formação do espaço metropolitano. O conceito de dispersão utilizado nesta pesquisa é definido por Caiado e Pires (2006), da seguinte maneira
No que se refere mais especificamente às alterações na configuração espacial, o fenômeno da dispersão da urbanização tem sido estudado no Brasil a partir da constatação da expansão do tecido urbano com ocupação em áreas isoladas da conurbação principal, com predomínio de baixas densidades, apoiadas em diversos sistemas de infraestrutura viária e dotadas de extensos espaços livres. São núcleos de urbanização separados no espaço, mas com a manutenção de vínculos estreitos com as demais areas da cidade, como parte de um único sistema urbano. (CAIADO e PIRES, 2006, p.277)

Coelho (2015) adiciona à essa definição, o fato de a dispersão ser caracterizada como a ocupação de áreas originalmente rurais ou haturais de forma descontínua, com áreas intersticiais entre os núcleos de urbanização contínuos, mas funcionalmente interconectadas. Afirma ainda, que a metrópole dispersa leva para as dinâmicas das áreas rurais o modo de vida urbano

A fragmentação do tecido metropolitano e os espaços de interação esgarçados escondem características que se apresentam pulsantes nas áreas urbanas. Ou seja, o modo de vida metropolitano nas áreas de dispersão urbana apresenta mudanças significativas em relação ao urbano, uma vez que existe desconcentração das atividades em escala regional. O que passa a existir é a mistura de dinâmicas locais e globais como aponta Reis (2006, p.151),

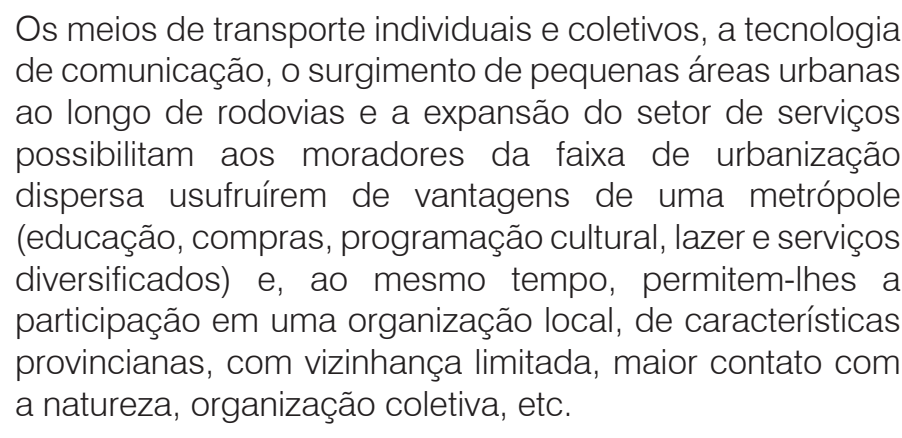

Mas, quando se trata de planejar e projetar sobre a metrópole, essa transescalaridade das dinâmicas dos habitantes da metrópole dispersa, que possibilita a heterogeneidade de atividades e diversidade de possibilidades de modo de vida, esbarra na visão típica de vida urbana com núcleos urbanos centralizados, reduzindo a sua complexidade. A 
mudança de tratamento da metrópole, no entanto, encarando-a como território formado por núcleos especializados que se distribuem na região, possibilita compreender que há, de fato, relações de trocas diversificadas. É por essa razão que se faz importante o estudo destas novas formas de configuração do território, para que seja possível reconhecer e compreender os diferentes modos de vida que se desenvolvem nestas áreas, conforme aponta Reis (2006).

E é exatamente o estudo das dinâmicas que acontecem nas áreas intersticiais, fora dos núcleos urbanos consolidados e que se misturam com as áreas rurais, que interessa a esta pesquisa.

Não apenas compreender a forma urbana, mas também as formas de ocupação e apropriação pela população dos espaços da metrópole dispersa são objetivos desta pesquisa, tratando a questão como um processo complexo e superando a visão restrita ao estudo dos condomínios horizontais e loteamentos fechados. Conforme mostra Reis (2006), os condomínios são os objetos de crítica mais comuns quando se trata de dispersão urbana, mas reduzir as questões da metrópole a eles é simplificá-las e se limitar a discutir as suas consequências, ignorando o conjunto de transformações pelas quais passam as metrópoles.

O objetivo principal deste estudo é, assim, superar a simplificação do que significa o modo de vida metropolitano, geralmente reduzido à análise das ocupações físicas do território ou às questões econômicas e políticas que induzem (ou não) a sua ocupação. O que se propõem é entender as dinâmicas cotidianas da metrópole dispersa, característica presente nas formações metropolitanas do interior de São Paulo. Para isso, é importante compreender como o fenômeno da dispersão urbana se qualifica no desenvolvimento das cidades do interior paulista, especialmente na Região Metropolitana de Campinas.

No interior do estado, o crescimento urbano ocorre, desde o início, através da dispersão urbana, sem formar grandes núcleos, mas através da criação de pequenos polos, ao redor das rodovias.
Segundo Reis (2006, p.68):

Nas áreas polarizadas por cidades de porte médio, como no interior do estado, onde o crescimento urbano fol intenso (...), a configuração do território já se fez com a de núcleos de grande porte. Em seu lugar, ocorre uma crescente integração de um número elevado de pequenos polos e a multiplicação de áreas de dispersão, inclusive ao longo das principais rodovias.

A descentralização da indústria da metrópole de São Paulo, em direção ao interior do estado é um dos fatores responsáveis pela dispersão urbana nestas regiões. Os Planos Nacionais de Desenvolvimento (PND I e II) são políticas públicas que estimularam a descentralização industrial de São Paulo, através do oferecimento de apoio das cidades médias do interior do estado, com a implantação de distritos industriais e melhoria de serviços específicos (TAVARES, 2018)

De acordo com Tavares (2018), este processo de industrialização do interior trouxe diversos benefícios para as cidades médias e pequenas que ali se localizam, como a valorização da terra, a atração de novos investimentos e a consolidação de áreas já ocupadas. No entanto, essas grandes infraestruturas de escala regional, geraram conflitos nas relações entre as diversas escalas, impactando, assim, o desenvolvimento urbano e regional. E uma das respostas a essas deseconomias da aglomeração industrial é a própria dispersão urbana, com a ocupação dos espaços afastados dos núcleos urbanos consolidados, próximos às rodovias que se instalam às margens destas cidades, tornando-se o principal atrativo deste processo.

Esse movimento da indústria foi acompanhado e incentivado pela implantação de um sistema rodoviário eficiente e articulado, em todo o estado. Isso assegurou, como aponta Reis (2006), que São Paulo fosse definida como principal polo de desenvolvimento industrial e de emprego do país e que houvesse gigantescas migrações rural-urbanas e interregionais, que deram origem às áreas metropolitanas. Além disso, esses movimentos deram condições à formação de áreas metropolitanas 
periféricas, que já surgiram com características de dispersão urbana e, ao mesmo tempo, à descentralização industrial.

Dentro deste contexto, segundo Coelho (2015), a Região Metropolitana de Campinas possui uma característica única em relação às outras regiões metropolitanas do país, que é a abrangência, da dispersão, por todo o território metropolitano. Nesse contexto, é possível observar não apenas a dispersão de ocupação física, mas também funcional, na qual as atividades cotidianas, de moradia, trabalho e estudo, por exemplo, acontecem em diversas cidades, mas de forma interconectada.

Todos estes movimentos pelo território metropolitano só são possíveis pela importância das rodovias na construção das metrópoles do interior sendo a mobilidade a característica primordial na sua compreensão. E a mobilidade metropolitana pode aqui ser compreendida, de acordo com Reis (2006), não apenas de pessoas e moradias, mas também em relação às unidades de produção e consumo, que se tornam móveis e atraem dinâmicas populacionais, seja de migração, seja de movimentos pendulares.

Com a mobilidade das unidades de produção, das indústrias e demais atividades econômicas, que se espalham pelo território, ao longo dos eixos rodoviários, teve origem o processo de dispersão e de regionalização do mercado de mão-de-obra industrial (REIS, 2006). Mas, em todo este processo, além dos movimentos dos trabalhadores fabris, houve um movimento de deslocamento de populações de alta renda para as bordas das metrópoles, atualmente muito presente nas dinâmicas da Região Metropolitana de Campinas (RMC).

Ao contrário da objetividade do movimento dos trabalhadores em busca do trabalho nas indústrias, a motivação da população de alta renda em buscar essas áreas tem motivações contraditórias. Segundo Reis (2006), existem duas causas principais, ainda que contrárias. Por um lado, o interesse pelo acesso às condições da vida metropolitana, de integração ao contexto regional. E, de outro lado, a busca pelo contato com a natureza como forma de negação à metrópole ou de rejeição à vida urbana e compensação pelas limitações impostas pela vida nas áreas urbanas mais densas, ou pela complexidade e desgaste da vida metropolitana.

Importante destacar, no entanto, que essas motivações são questionáveis quando se trata da ocupação destas áreas por meio de condomínios e loteamentos fechados. A vida entre iguais e a fuga dos conflitos dos espaços urbanos parecem muito mais importantes para o modo de vida dessa população que a busca pela reconexão com a natureza.

De qualquer forma, esses movimentos de diversos setores econômicos e sociais tornam o espaço da metrópole dispersa mais complexo, por ter que fornecer condições para que as dinâmicas cotidianas de todos esses grupos aconteçam. No entanto, os espaços metropolitanos com essas características geralmente existem sem planejamento e projetos específicos que permitam a sua ocupação de forma ordenada e sem prejuízos. Segundo Reis (2006, p.35), "os estudos de arquitetos tendem a enfatizar as preocupações com as questões de projeto urbanístico e com a ineficácia dos modelos tradicionais de planejamento urbano, para lidar com a nova realidade, e as limitações de algumas das soluções adotadas, em termos de projeto".

Visto, portanto, que a dispersão urbana é causa e consequência do protagonismo do sistema rodoviário na metrópole, procura-se, aqui, contribuir para essa discussão tomando por eixo condutor a mobilidade, atrelada às discussões do cotidiano e da vida pública que se desenvolve no espaço metropolitano, com foco nas áreas lindeiras ao sistema rodoviário.

\subsection{A MOBILIDADE}

Os transportes e as comunicações são fatores imprescindíveis na formação da metrópole dispersa, uma vez que permitem rompimentos de espaço e tempo, ampliando as possibilidades de acessibilidade e localização no 
território. Podem ser consideradas como elementos fundantes, ao mesmo tempo que são parte integrante da metrópole, uma vez que permite e induz a sua forma, como aponta Marandola (2008).

Dada a sua importância, cabe destacar que a mobilidade pode ser considerada como fator potencial, já que mesmo as pessoas com pouca mobilidade a têm como forma de habitar a metrópole. Mas, conforme aponta Marandola (2008), ela também pode ser elemento estruturador das segregações no espaço metropolitano, visto que "mover-se é condição para poder ser e, às vezes, para continuar sendo. A mobilidade deve ser vista como direito, não como bem de consumo" (MARANDOLA, 2008, p.264).

Assim, visto que a mobilidade se configura como elemento de estruturação da metrópole, é através dela que a segregação da população também ocorre, seja ela espacial ou temporal. Espacial pela possibilidade de acesso físico às utilidades proporcionadas pela metrópole e temporal pela desterritorialização do homem em movimento, que não se apropria do seu espaço próximo, condição dada pela velocidade. Segundo Santos (2006, p.222),

Vivemos um tempo de mudanças. Em muitos casos, a sucessão alucinante dos eventos não deixa falar de mudanças apenas, mas de vertigem. O sujeito no lugar estava submetido a uma convivência longa e repetitiva com os mesmos objetos, os mesmos trajetos, as mesmas imagens, de cuja construção participava: uma familiaridade que era fruto de uma história própria, da sociedade local e do lugar, onde cada indivíduo era ativo. Hoje, a mobilidade se tornou praticamente uma regra. O movimento se sobrepõe ao repouso. A circulação é mais criadora que a produção. Os homens mudam de lugar, como turistas ou como imigrantes. Mas também os produtos, as mercadorias, as imagens, as ideias. Tudo voa. Daí a ideia de desterritorialização

No entanto, é possível compreender a territorialidade do homem no meio metropolitano de outra forma, como uma inversão de processos e pensando na participação do homem em duas escalas diferentes, ao mesmo tempo, não apenas em relação ao seu espaço próximo. 'territorializar-se' envolviadefinirfronteirasecontrolarespaços continuos, bem delimitados, agora estas delimitaçoes fixações podem representar mais 'desterritorialização' do que territorialização. Nossos territórios são construídos mais no movimento e na descontinuidade do que na fixação e na continuidade. Quem não participa dos movimentos 'globais' e se situa numa condição mais 'imóvel' - ou numa mobilidade insegura e 'sem controle' - pode estar mais vulnerável à desterritorialização. (HAESBAERT, 2004, apud MARANDOLA, 2008, p.145)

Ou seja, conforme aponta Marandola (2008), é necessário considerar a mobilidade como parte mais significativa do dia-a-dia da população metropolitana, fazendocomquesuasterritorialidades sejam compreendidas pela extrapolação do lugar e da comunidade, e considerando trajetos feitos com frequência ou mesmo pontos distantes da zona de proteção do homem, seja sua casa, seja seu bairro. "Os espaços da mobilidade, portanto, tem que sofrer processos de territorialização para que sejam apropriados, material ou simbolicamente, para promoverem a proteção". (MARANDOLA, 2008, p.180)

Os mecanismos tradicionais de proteção e territorialização não são suficientes no espaço metropolitano, o que não quer dizer que não existam relações humanas nestas áreas. As pessoas continuam se apropriando destes espaços de formas diversas, ainda que eles não estejam preparados para essas dinâmicas. $O$ fato de as pessoas percorrerem trajetos de caráter quase regional, ou utilizarem espaços voltados à essas dinâmicas tornam as relações mais efêmeras, porém não as inibe de acontecer

A percepção dessas relações humanas no espaço da mobilidade metropolitana passa pela observação do cotidiano e da compreensão de que a velocidade, relacionada às dinâmicas globais da metrópole, tem papel fundamental na descoberta da relação corpórea do homem com o meio. De acordo com Santos (2006, p.212) "o mundo da fluidez, a vertigem da velocidade, a frequência dos deslocamentos e a banalidade do movimento e das alusões a lugares e a coisas distantes, revelam, por contraste, no ser humano, o corpo como uma certeza materialmente sensível, diante de um universo difícil de apreender". 
Dado que a metrópole dispersa tem na velocidade seu fator estruturante, esta pesquisa tem como objetivo buscar as relações humanas que emergem no território, que extrapolam as questões relativas apenas ao estudo da configuração do meio físico e compreendendo as múltiplas velocidades presentes no espaço metropolitano.

Assim, a investigação das relações humanas deve passar não apenas pela leitura de dados e estatísticas, mas pela vivência do espaço e pela compreensão de que o estudo da mobilidade não pode ser encarado da forma em que atualmente o tema é tratado, através de dados de origemdestino e do conceito tradicional de pendularidade. Esses estudos já não são mais suficientes para compreender a mobilidade nas metrópoles contemporâneas, como indica Marandola, Guedes e Silva (2010).

As características da metrópole contemporânea, dispersa, são muito distintas das metrópoles da época da industrialização, sendo necessário rever as formas de tratar a mobilidade. Segundo Pires (2007), nas metrópoles industriais o deslocamento casa-trabalho era o principa motivo da mobilidade, estando a expansão do transporte de massa diretamente relacionado à extensão das áreas metropolitanas. $\mathrm{Na}$ metrópole contemporânea, onde a dispersão urbana, populacional e econômica é uma realidade, a flexibilização do trabalho deixou de ser uma referência fundamental na organização da vida do cidadão metropolitano. A amplitude de escolha de onde morar passa a ser uma possibilidade estando atrelada a múltiplas razões.

$$
\begin{aligned}
& \text { O que temos, portanto, são mobilidades pessoais, que } \\
& \text { são desenhadas, segundo Kellerman (2006), tanto pela } \\
& \text { efetividade da mobilidade quanto por sua virtualidade. } \\
& \text { Mesmo que não tenhamos uma mobilidade diária, ter } \\
& \text { potencialmente acesso faz parte de um modo de vida } \\
& \text { metropolitano. Extensão, acessibilidade, velocidade, } \\
& \text { conveniência e fixidez são alguns dos elementos que } \\
& \text { as pessoas levam em consideração e/ou interferem na } \\
& \text { constituição das mobilidades e trajetórias pessoais, } \\
& \text { envolvendo tomadas de decisões e uma biografia (ego) } \\
& \text { que decide. (MARANDOLA; GUEDES; SILVA, 2010, p.182) }
\end{aligned}
$$

Essas múltiplas possibilidades fazem com que os trajetos diários na metrópole sejam irregulares, no tempo e no espaço. Segundo Marandola
Guedes e Silva (2010), portanto, a mobilidade cotidiana intrametropolitana pode ser definida a partir de três elementos principais: as escolhas individuais, as preferências e os valores; a acessibilidade, que depende dos meios de transporte; e a quantidade e qualidade das informações e do envolvimento das pessoas com o lugar.

Sendo assim, é importante compreender que a mobilidade na metrópole trata não apenas dos grandes fluxos, mas das mobilidades cotidianas, dos múltiplos fluxos, com variadas funções e nas diversas escalas de relação. Elas ocorrem de forma irregular, não tendo como foco apenas a sede metropolitana, mas outras áreas que compõem o território metropolitano, como os outros municípios ou mesmo as áreas intersticiais entre núcleos consolidados, resultados da dispersão urbana, como apontam Marandola Guedes e Silva (2010). Esta mobilidade está intimamente ligada ao modo de vida metropolitano e as formas de apropriação deste espaço.

\subsection{ESPAÇOS DE VIDA METROPOLITANOS}

Além da velocidade, do movimento, da mobilidade, é parte da composição do cotidiano da metrópole, dos seus espaços livres, a permanência as relações humanas, a comunidade e a vizinhança. O conceito de "espaços de vida", como utilizado por Marandola (2008), em sua tese sobre as formas de habitar a metrópole será utilizado como uma forma de aproximar a mobilidade da permanência, ultrapassando o lugar comum nas investigações sobre mobilidade, uma vez que o autor utiliza um conceito que se propõe a modificar as formas de medir e considerar os movimentos, incorporando aos dados temporais os dados espaciais, além de hierarquizar as estruturas do território de acordo com a o conjunto de lugares e itinerários de cada pessoa.

Como apontado anteriormente, o reconhecimento de um modo de vida metropolitano é essencial na descoberta das dinâmicas do território, para 
além da informação dos grandes deslocamentos, geralmente atrelados às condições econômicas da população e das relações de dependência entre cidades

Em sua tese, Marandola procura identificar o padrão dos espaços de vida da Região Metropolitana de Campinas através da análise do cotidiano de moradores de cidades do eixo da rodovia Anhanguera. É importante destacar que os espaços de vida são diferentes para cada situação, de cada metrópole, dependendo das condições de sua formação. No caso de Campinas, a dispersão do espaço metropolitano é um fator essencia na sua compreensão, assim como a escala da observação das dinâmicas e relações dentro destes espaços fragmentados. Conforme aponta Marandola (2008), é importante, em Campinas, olhar além das fronteiras dos municípios, a fim de entender como as pessoas desenham seus espaços de vida cotidianamente no espaço metropolitano.

A primeira característica a ser apontada é que os habitantes da RMC têm maior dependência das rodovias do que do núcleo urbano da cidade sede, visto que os movimentos cotidianos geralmente envolvem mais de um ou dois municípios. Segundo Marandola (2008, p. 134),

A mancha metropolitana da RMC (..) parece homogênea a um olhar apressado. No entanto, a forma urbana da região não obedeceu, como nas metrópoles industriais o padrão "mancha de óleo", espalhando-se a partir de um centro polarizador concentrado, de forma gradativa O padrão fragmentado de metrópoles como Campinas é rizomático, fortemente estruturado pelos corredores viários. Estes, além das grandes rodovias estaduais (Anhanguera Dom Pedro I, SP-340, SP-332, SP-101 e Santos Dumont), è complementado por avenidas e ruas que estabelecem as conexões entre os pedaços da metrópole.

Outro fator importante na dinâmica da RMC é a que as relações não são próximas, de conurbação. Os eixos lineares são mais presentes e efetivos, com equipamentos que fazem acontecer alguns fluxos transversais a esses eixos. Como aponta Marandola (2008), as relações não acontecem por grandes áreas de contato entre os municípios, mas através dos fluxos, em linha, que integram as diversas áreas e lugares, visto que os acessos e conexões são reduzidos.
A mobilidade, portanto, tem que ser encarada de outra forma, nesta região. Como as relações de vizinhança são esgarçadas, difusas no território, os espaços da mobilidade assumem outro caráter, uma vez que as distâncias e o tempo de deslocamento aumentam, mantendo os habitantes cada vez mais tempo fora do seu espaço seguro, sua vizinhança imediata, típica do espaço intraurbano. Assim, como aponta Marandola (2008), os recursos de proteção, que no espaço urbano pode ser representado pela casa ou pelo bairro, estão dispersos no espaço regional metropolitano ou, ainda, espalhados pela rede de localidades globais, em uma outra escala de relações, como é o caso de Campinas, que se relaciona diretamente, de diversas formas, com a macrometrópole.

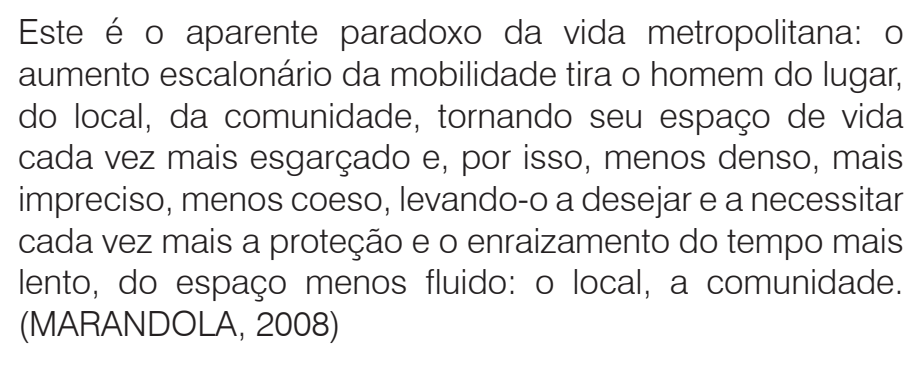

Dessa forma, a questão que se apresenta é: quais são os espaços nos quais estão presentes esses recursos de proteção que substituem a casa e o bairro como elementos de vínculo com a comunidade, em uma escala humana? A observação das dinâmicas singulares cotidianas da metrópole, que ocorrem de diversas formas nos espaços de mobilidade metropolitanos, é uma das formas que esta pesquisa busca para identificar estes espaços, de realização da vida pública.

\subsection{A PERMANÊNCIA}

A perda do sentido de comunidade na metrópole é apontada por Reis (2006), considerando as histórias da construção dos subúrbios americanos do século XIX até as áreas de dispersão do século XX. A essa mesma conclusão chega Marandola (2008), na sua tese sobre os espaços de vida 
da RMC, constatando que existe um afastamento entre o homem e seus espaços de segurança, de reconhecimento, familiar, quando inserido no espaço metropolitano, agravado pelo fenômeno da dispersão, conforme apontado anteriormente.

Casa e bairro são símbolos da segurança e da estabilidade. São o ponto, a pausa, o oposto ao movimento. Esses atributos, no entanto, sáo modficados na fluidez desaregar o lugar e diminuir a aderência às escalas próximas como o bairro A cas parece tornar-se uma iha para a qual vamos para pousar com cada vez menos tempo Tomando a dissociac̃a residência trabaho e aumento da distência entre eles como elementos-chave da mobilidade metropolitana faz-se necessério comprender as novas relações que se estabelecem entre a escala local (a casa, o lugar, o bairro) e as escalas regional e global. Procuram o desviar da noc̃a maniqué́sta de que a virtude é do lugar e o perigo é do espaço. Trata-se, isto sim, de comprender as novas formas de recõa com a casa e o bairro no espaço metropolitano regional enquanto fontes materiais e simbólicas da segurança/insegurança existencial. (Marandola, 2008, p.169)

Neste contexto, quais seriam os espaços que representariam o ponto, a pausa, o oposto ao movimento, como aponta Marandola, quando se trata do espaço metropolitano? Quais as formas de enraizamento e de identidade na metrópole? Se na cidade existe o bairro e a vizinhança, na metrópole devem ser encontradas novas formas de pertencimento e de apropriação do espaço, sendo a própria mobilidade, que representa o movimento, fator de fundamental importância. Segundo Marandola (2008, p.146),

Se o "nós" está disperso pela metrópole, é exatamente pela sua existência e da mobilidade que isso é possível. (...) Se na metrópole esta identidade não está no lugar, no bairro,
nos valemos dos meios necessários para consolidar tais laços. Na metrópole, os laços podem estar dispersos, mas tão presentes quanto em uma pequena cidade ou uma região rural, com diferentes naturezas, mas "enraizando" o homem de alguma forma.

O papel da mobilidade nessa situação é que ela permite a reorganização da vida cotidiana, como aponta Reis (2006), quando uma parcela da população passa a se relacionar em uma escala regional, deixando de ter as cidades como sede da sua vida cotidiana. O fato é que não apenas o homem está disperso no território, em um modo de vida esgarçado, mas também as atividades que dinamizam o espaço metropolitano.

Segundo Reis (2006), existe também um aumento na mobilidade do comércio e dos serviços, dada a regionalização do cotidiano. Assim, as oportunidades de emprego na metrópole são promovidas a partir de dinâmicas em escala regional, assim como as atividades relacionadas ao estudo e ao lazer.

O que se sugere aqui, é que o cotidiano é a chave da compreensão do modo de vida metropolitano, considerando as características dos espaços de vida da metrópole dispersa expostos até o momento, não apenas nas questões de mobilidade (modo de vida metropolitano), mas também na permanência, representada pelas possibilidades de apropriação dos espaços pelo homem que o frequenta. De acordo com Queiroga (2012, p.40)

"a esfera do cotidiano corresponde, em termos espaciais ao que Lefebvre (2009), em sua tríade espacial, denominou
'espaço percebido': o espaço da prática social, o espaço dos sentidos, da produção e da reprodução do trabalho do lazer, definido, em suma, pela vida cotidiana".

Em sua tese de livre docência, Queiroga (2012) define a expressão "esfera de vida cotidiana" como forma de atravessar as noções de comunidade de Sennett e de esferas de vida privada, social e pública, de Arendt dinamizando a caracterização da vida humana pelas suas complexidades.

Mas, para essa pesquisa, dentro da vida cotidiana, o que tem maior relevância é a esfera de vida pública, uma vez que se trata dos espaços públicos e da vivência das dinâmicas intrametropolitanas. Queiroga (2012, p.49) assim denomina esfera pública geral como "toda a vida 'em público', incluindo, portanto, o debate público (político e intelectual), a ação comunicativa, inclusive cotidiana, e qualquer outra ação que se compartilhe 'em público', seja no espaço real, seja no virtual”.

Importante ressaltar que a vida pública que será considerada nesta pesquisa não é somente a vida com intenções políticas, mas cotidianas. 
Ainda segundo Queiroga (2012), é necessário reconhecer as qualidades na vida em público que acontecem em ações cotidianas, que não tenham intenções políticas, como num passeio pelo parque, por exemplo. "O convívio público voluntário ou involuntário, possui um grau de civilidade que, em harmonia ou em conflito, já se constitui parte da vida pública, integrante da esfera pública geral” (QUEIROGA, 2012, p.49).

O que não se pode confundir são os conceitos de espaço público de esfera de vida pública, visto que, segundo Queiroga (2012), o espaço público pode ser definido como uma instância social híbrida entre materialidade e ação, enquanto a esfera de vida pública se define como o campo de relações sociais do mundo vivido, desde a vida familiar à vida pública política.

O que se propõe nesta pesquisa é um estudo que considera não apenas a análise dos espaços públicos metropolitanos, mas das espacialidades da vida pública, considerando as dinâmicas da metrópole.

$$
\begin{aligned}
& \text { As práticas espaciais da esfera pública denominadas } \\
& \text { espacialidades daesfera públicaaindaque majoritariamente } \\
& \text { se deem nos espaços livres públicos, sobretudo nos bens } \\
& \text { de uso comum do povo, podem se realizar em diferentes } \\
& \text { espaços: livres ou edificados, públicos ou privados. A } \\
& \text { esfera pública geral se efetiva, portanto, em um amplo } \\
& \text { sistema de espaços, com maior ou menor intensidade } \\
& \text { neste ou naquele lugar. (QUEIROGA, 2012, p.59) }
\end{aligned}
$$

Ou seja, busca-se identificar os espaços públicos nos quais a vida pública se mostra e se realiza, além de compreender quais as peculiaridades da vida pública quando se insere em um contexto metropolitano, onde a mobilidade é fator preponderante na estruturação dos espaços de vida. Importante destacar que a observação das dinâmicas cotidianas metropolitanas pode revelar a presença de atividades que seriam características dos espaços públicos típicos, por exemplo, bater papo em uma praça, em espaços inesperados, visto que os espaços livres públicos da metrópole dispersa dificilmente serão caracterizados como um espaço urbano tradicional.
Dessa forma, o que se pretende é compreender os espaços além da sua materialidade, sua forma, ou sua classificação tipológica, com a função para qual é designado o espaço, como incentiva Queiroga (2012). Para o autor, também "importa reconhecer as apropriações espaciais realizadas pela população tanto quanto o desempenho do sistema de objetos que suportam (in)determinadas ações da esfera pública" (QUEIROGA, 2012, p.61)

E no contexto metropolitano, identifica-se uma grande variedade de espacialidades da vida pública, visto que ela é mais flexível, variável e complexa que o espaço intraurbano. Na metrópole, por exemplo, é possível listar os empreendimentos fechados com usos não residenciais, como as indústrias, os shoppings centers, as universidades, os polos tecnológicos, por exemplo, que têm caráter regional, não pertencendo a cidades específicas, mas a regiões mais amplas.

Estes novos espaços são exemplos claros das possibilidades de espacialidades inesperadas na metrópole. Mas não são apenas estes que devem ser considerados, principalmente quando tratamos dos espaços livres públicos da metrópole dispersa, em que as rodovias são importantes espaços de realização da vida pública. Segundo Queiroga (2012, p.235), "nesse contexto de aumento das distâncias de deslocamento cotidiano de número já significativo de habitantes, os espaços públicos mais representativos não estão mais na escala da vizinhança: a avenida virou estrada, a praça rotatória".

Essa dissertação se propõe a investigar é a relação contrária, na metrópole dispersa. A estrada virou avenida, a rotatória virou praça? 
CAPÍTULO 2

A RMC E A MOBILIDADE - A ESCALA METROPOLITANA 


\section{A RMC E A MOBILIDADE - A ESCALA METROPOLITANA}

Visto que a mobilidade e a permanência são os conceitos que guiam esta pesquisa, na busca pelas espacialidades da vida pública nos espaços de mobilidade metropolitanos, é importante contextualizar o objeto de estudo escolhido, a Região Metropolitana de Campinas (RMC) e a sua região norte, estruturada pela Rodovia SP-332. Este eixo compreende as cidades de Campinas (cidade sede), Paulínia, Cosmópolis, Artur Nogueira e Engenheiro Coelho.

O primeiro motivo desta escolha é a vivência pessoal da RMC, enquanto morador de uma das cidades pequenas que compõem a metrópole. Os questionamentos e inquietações acerca das dinâmicas ali presentes são o início deste estudo, visto que sempre me senti pertencente muito mais à região metropolitana que à cidade na qual nasci e vivi todo este tempo, mesmo sem saber da existência de um modo de vida metropolitano.

Morei em Cosmópolis, estudei em Artur Nogueira, Holambra e Campinas, cada cidade em uma etapa de vida. Trabalhei e fazia compras em Campinas, passeava por Paulínia, realizava tratamentos de saúde em Barão Geraldo. Tinha amigos em todas essas cidades, entre muitas outras da RMC ou de seu entorno mais próximo, como Limeira. Toda essa vivência me permitiu observar que a mobilidade possui uma importância essencial para a população da RMC e que os espaços destinados a ela têm, geralmente, uma grande mistura de pessoas com objetivos, destinos e condições de vida diferentes. Ser usuário diário da Rodovia SP-332 despertou o interesse na descoberta do seu papel estruturador de um dos eixos da RMC e nas possibilidades da sua construção enquanto elemento não só de circulação, mas de permanência e ocupação.

Desta forma, o objetivo da pesquisa e minha experiência pessoal se aproximam na compreensão dos espaços metropolitanos e no reconhecimento de situações que não se apresentam de forma clara. 
Pretende-se, aqui, construir o cenário do modo de vida desta região, superando, assim, a impressão de que são simples as relações que se estabelecem nas cidades pequenas que pertencem à Região Metropolitana de Campinas, seja pela sua participação intensa nas dinâmicas metropolitanas, seja pela complexidade dos cenários existentes nessa região, principalmente nas áreas de transição entre os espaços urbanos e rurais, intersticiais, que possuem relações próprias, distintas dos espaços intraurbanos.

Assim, a área de estudo escolhida permite compreender o modo de vida peculiar da RMC, tanto pela forma de ocupação do território, por meio da dispersão urbana, quanto pela transescalaridade das dinâmicas da região, principalmente pela presença de atividades de interesse global. A área permite observar, ainda, que o modelo de planejamento e de projetos urbanos baseados nas metrópoles industriais concentram empreendimentos e investimentos que, contudo, não configuram uma região metropolitana realmente integrada.

Portanto, o segundo motivo da escolha pela RMC é a possibilidade e o interesse de descobrir o que significa o seu modo de vida metropolitano, ainda bastante complexo, dividido e sobreposto entre as áreas urbanas e rurais, nos tempos lentos e nos tempos rápidos. O dilema metrópoleinterior, por exemplo, é citado por Marandola (2008, p.119).

O embate metrópole-interior está inscrito na vida tão interior raro metropole para quém ve compinas está meio caminho dos dois. Esses dois atributos que sempre caminharam como dois polos em oposição se uniram em Campinas para compor parte da essência da cidade. Essa ambiguidade é compartilhada com as cidades da região. Mesmo que nenhuma outra cidade chegue perto da escala urbana de Campinas, são vistas como interior no imaginário regional e estadual, mesmo que o ritmo de vida nessas cidades já as coloque em processo de transição. Ser "da região de Campinas" traz a metropolização e os traços metropolitanos, bons e ruins.

Essa proximidade da RMC com o interior é uma das duas principais características. Segundo Reis (2006), Campinas possui uma característica diferenciada, já que áreas urbanizadas dos núcleos urbanos consolidados não se encontram no território, como ocorre na região de São Paulo. Na RMC, formam-se bairros isolados, em meio às áreas rurais, com fábricas, loteamentos fechados, shoppings e universidades, criando áreas de complexa definição, onde "já não se sabe onde é o campo, onde é a cidade" (REIS, 2006, p.79). Existe a proximidade física entre o urbano e o rural, o entrelaçamento de áreas que faz com que as dinâmicas não sejam apreendidas de forma clara. As atividades urbanas e rurais se confundem, mas todos os espaços se integram, principalmente pela forte presença dos elementos que possibilitam a mobilidade da população de forma geral. É um mundo novo, com um modo novo de vida urbana, no
qual muitas pessoas circulam de um setor para outro em
carros particulares ou em ônibus fretados e vans, para ir a
universidades, a shoppings, aos seus locais de trabalho ou
para voltar a seus condomínios e loteamentos fechados.
(REIS, 2006, p.79)

Outra característica importante da RMC, portanto, é a sua desconcentração em relação aos modelos metropolitanos industriais, envolvendo toda a região nos seus processos e dinâmicas e colocando a dependência da sede metropolitana em segundo plano. A dispersão é bastante presente na forma da metrópole campineira e as rodovias aparecem com destaque. Segundo Caiado e Pires (2006), prevalecem os fluxos na organização regional e os corredores viários ganham importância na conexão das áreas dispersas da região metropolitana, o que garante maior permeabilidade dos processos metropolitanos entre todas as cidades que compõem a região.

Assim, a comunicação/conectividade e o transporte/mobilidade são duas condições essenciais para a metrópole dispersa, de dinâmicas não industriais, que estão disponíveis em abundância na RMC. Elas influenciam não apenas na forma metropolitana, nas suas relações internas, mas também nas suas relações externas. Segundo Marandola (2008), o sistema de rodovias, que conecta as cidades da região com a Região Metropolitana de São Paulo, com o aeroporto de Viracopos, o interior do Estado de São Paulo e o porto de Santos, e a presença de uma rede de 
fibra ótica e de outras redes de telecomunicação de grande extensão são elementos destacadamente desenvolvidos na RMC

As relações globais possibilitadas por essa condição da RMC definem, de certa forma, as características da população atraídas por ela e, por consequência, as formas pelas quais será ocupada. No caso da RMC principalmente no eixo estruturado pela SP-332, são os "trabalhadores do conhecimento", atraídos pelos polos tecnológicos e pelas indústrias de alta tecnologia que induzem a forma urbana e a organização socioespacial em conjunto e em contraposição à ocupação de outros eixos da RMC que concentram a população de renda mais baixa, como é o caso do eixo da Rodovia Anhanguera.

Apesar de ser uma região de altíssimo valor econômico, é importante destacar a região apresenta grandes problemas, relacionados à metropolização. Segundo Cunha et al. (2006), ao mesmo tempo que a região de Campinas expandiu, também acumulou questões indesejadas, como a alta concentração de pobreza, desemprego, violência e desigualdade social, que geraram, no território, segregação espacial.

A análise da formação da RMC, composta por eixos radiais definidos pelas rodovias, permite verificar a predominância de determinadas classes sociais em cada um desses eixos, o que demonstra a segregação espacial da região. Segundo Pires (2006), nas regiões sudoeste e noroeste, padrão de urbanização pode ser caracterizado pela precariedade dos assentamentos urbanos. Ao norte, eixo da Rodovia Zefferino Vaz, existe o predomínio das camadas de renda média e alta. À leste, existe variação na predominância nas camadas de renda, sendo mais baixas quanto mais próximas à cidade de Campinas e mais altas em direção aos municípios menores.

Seguindo essa lógica, baseada nas demandas imediatas, o Plano Integrado de Transportes Urbanos (PITU 2015) (FECAMP, 2006), elaborado pela Secretaria dos Transportes Metropolitanos do Estado de São Paulo (STM), prioriza em seus projetos e planos apenas iniciativas para as

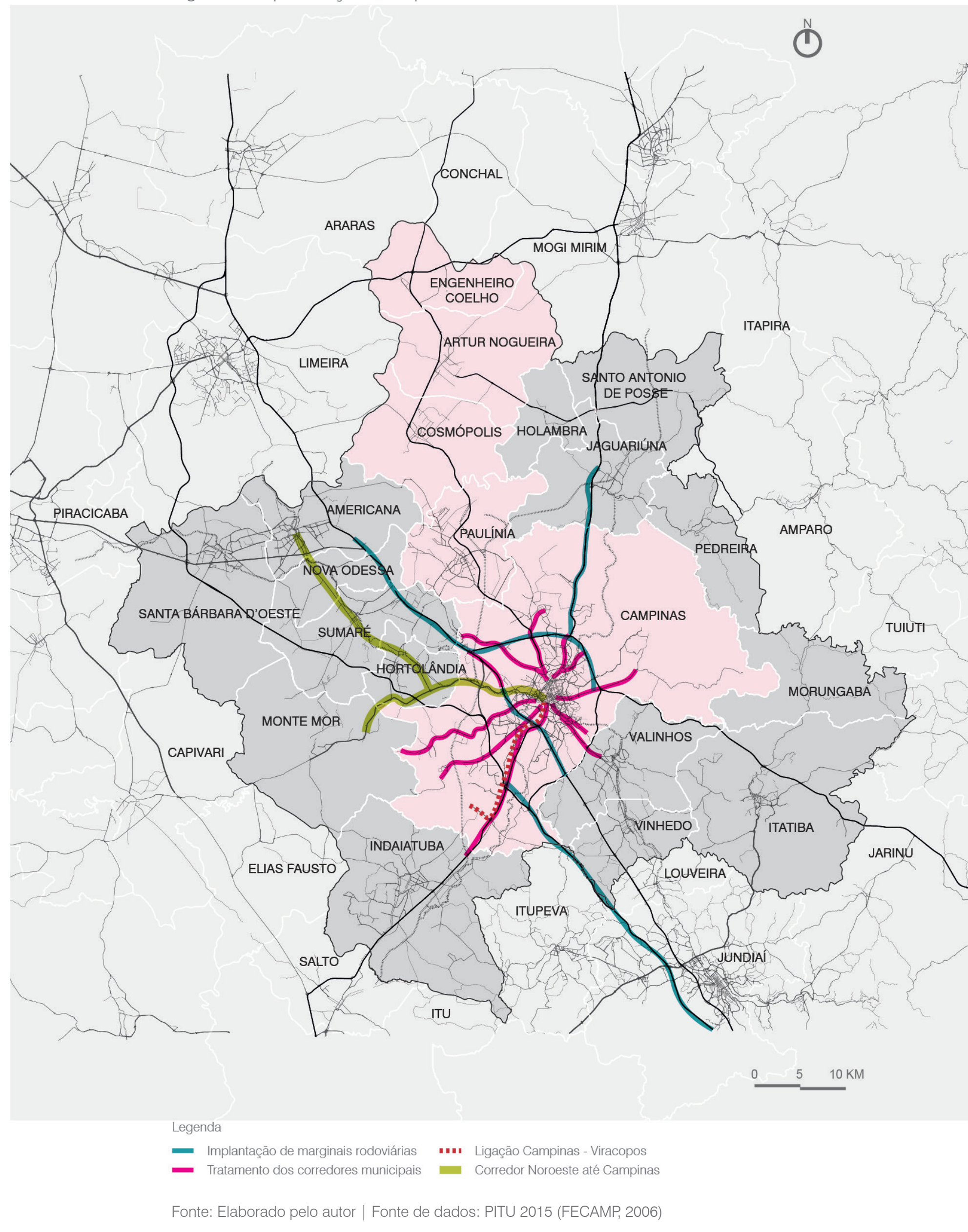


áreas de menor renda, como demonstra a Figura 4. Ainda que esta seja a condição mais óbvia e, de fato, mais necessária, considerando a demanda por transportes públicos coletivos da população mais pobre, é importante ressaltar a falta de iniciativas para as áreas ao norte da RMC

Além de não considerar as necessidades da população mais pobre desta área, este tipo de planejamento de transporte não colabora com a superação da segregação espacial existente. Enquanto a atração da população dependente de transporte público coletivo continua acontecendo apenas no eixo contemplado por projetos específicos de transporte, as áreas não contempladas seguem como espaço exclusivo de usuários de transporte individual. Ainda que exista predominância de classes mais altas ao norte e de ocupações de condomínios de alta renda, é importante perceber que existe população de baixa renda que se encontra desatendida com esses rumos do planejamento.

Para esta pesquisa serão analisadas, portanto, áreas que não são priorizadas em planos e projetos de transporte, com o objetivo de entender o cenário metropolitano para além das respostas às grandes demandas, tratando a metrópole como um sistema, no qual cada uma de suas partes apresenta especificidades válidas de análise e passíveis de intervenção.

Outro motivo pela escolha do eixo da SP-332 como recorte de estudo, é o fato de esta área estar em processo de desenvolvimento, sendo uma das áreas de ocupação mais recentes na RMC, com a implantação de novos loteamentos e condomínios fechados. Os mapas da Pesquisa O/D de 2003 (Figura 5), realizados com base em estudos da Empresa Paulista de Planejamento Metropolitano SA (EMPLASA) mostram um fluxo grande de viagens dos habitantes da cidade de Campinas em direção a este eixo, muito em razão da implantação destas áreas residenciais e das indústrias que compõem o polo tecnológico, mostrando a sua importância atual na configuração da metrópole.

É importante destacar que o eixo norte, que está em processo de ocupação, não apresenta conurbação entre as cidades, nem mesmo entre Paulínia e Campinas, maiores cidades do eixo. Este fator também colaborou na escolha do eixo para análise, visto que os elementos de mobilidade estão em processo de construção e definição. Como será abordado nesta pesquisa, a SP-332, espinha dorsal deste eixo, pode apresentar diversas formas, funções e características que não apenas de via de transporte.

Diante dessas motivações e a partir das considerações teóricas apresentadas no capítulo anterior, será apresentada, neste capítulo, a caracterização da RMC, com foco no eixo norte, da SP-332 e nas questões forma urbana, uso e ocupação e mobilidade.

Figura 5: Viagens externas por motivo trabalho e estudo com origem no Centro Metropolitano e destino por vetor de expansão urbana

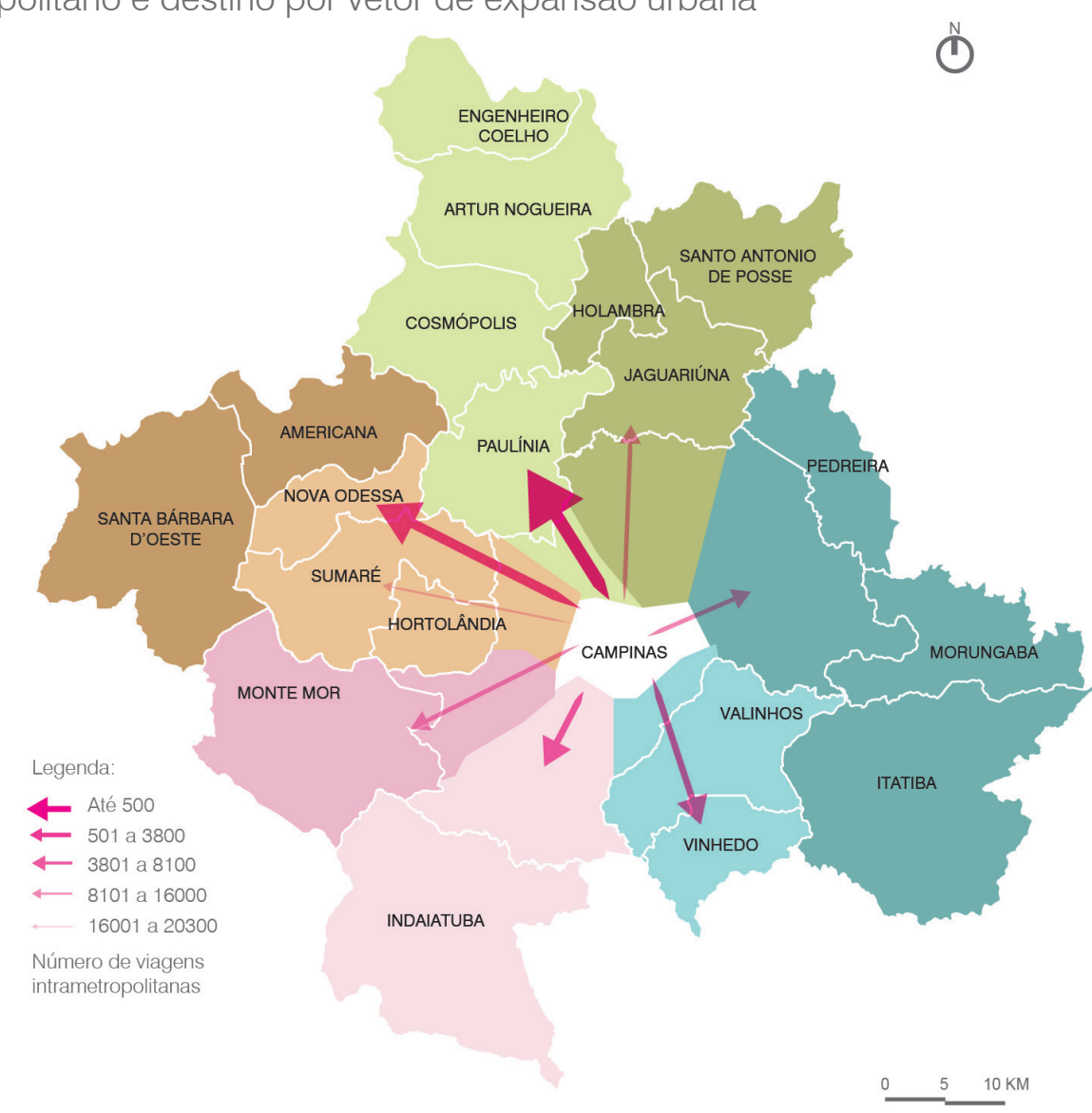

onte: Elaborado pelo autor | Fonte de dados: Pesquisa Origem-Destino 2003 (EMPLASA, 2003) 


\subsection{A RMC}

\subsubsection{DADOS GERAIS DA RMC}

A Região Metropolitana de Campinas foi criada pela Lei Complementar Estadual no 870, de 19 de Junho de 2000, sendo composta, hoje, por 20 municípios, com a inclusão, em 2014, da cidade de Morungaba. Os municípios da RMC são, portanto, os seguintes: Americana, Artur Nogueira Campinas, Cosmópolis, Engenheiro Coelho, Holambra, Hortolândia, Indaiatuba, Itatiba, Jaguariúna, Monte Mor, Morungaba, Nova Odessa, Paulínia, Pedreira, Santa Bárbara d'Oeste, Santo Antônio de Posse Sumaré, Valinhos e Vinhedo. A Figura 6 mostra a Região Metropolitana de Campinas, com seus municípios em destaque.

A população total da RMC é de 3,2 milhões de habitantes, em uma área de $3.791,79$ km² e se configura como a segunda maior região metropolitana do Estado de São Paulo, segundo dados do IBGE. A Tabela 1 apresenta um resumo dos municípios da RMC, mostrando, além das áreas e população de cada município, a sua densidade, o PIB e a Taxa geométrica de crescimento populacional anual entre o período de 2010 e 2018. Em destaque, as cidades do eixo da SP-332.

Seu destaque no cenário nacional baseia-se na sua posição econômica sendo seu PIB comparável a metrópoles estaduais de todo o país (QUEIROGA, 2012), destacando-se a presença do segundo maior aeroporto de cargas do país - Viracopos, localizado em Campinas - e que, segundo dados da EMPLASA foi a maior porta de entrada de mercadorias importadas, em 2015. Também apresenta indústrias de importância nacional - como a Petrobrás, presente em Paulínia - e um parque industria moderno e composto por diversos segmentos, configurando-se como polo tecnológico e científico, segundo dados da AGEMCAMP1. Além disso, a

1 A Agemcamp tem por finalidade integrar a organização, o planejamento e a execução das funçoes publicas de interesse comum na Regiäo Metropolitana de Campinas.

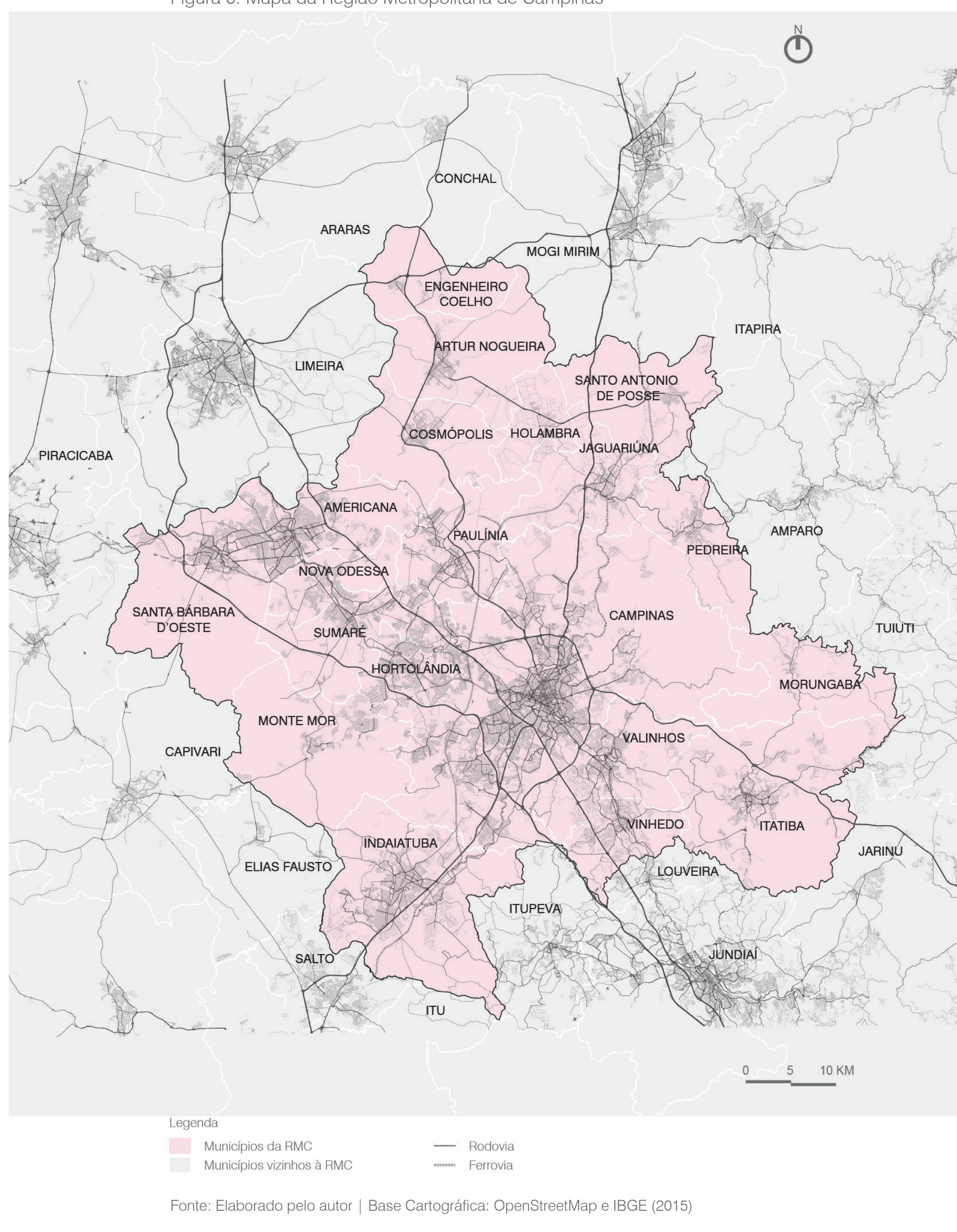


e nacional e de estruturação da megalópole do sudeste brasileiro $^{3}$. Destacam-se, neste sistema, as Rodovias Anhanguera e Bandeirantes que conectam a RMC à capital do estado e ao interior paulista, além da Rodovia D. Pedro I, que faz a sua conexão com o Vale do Paraíba e com a Rodovia Dutra, rumo ao Rio de Janeiro. Além destas rodovias de caráter regional, a RMC é composta por rodovias secundárias que estruturam seu espaço interno, o que permite que as relações entre municípios sejam intensas e que todos se conectem à essa estrutura regional, como é o caso da Rodovia Zefferino Vaz (SP-332).

\subsubsection{CARTOGRAFIA}

A base cartográfica desta pesquisa foi construída em software livre de georreferenciamento (QGIS), a partir de bases de dados disponíveis em plataformas abertas e em dados oficiais disponibilizados por órgãos do governo, nas esferas nacional, estadual e municipal.

No intuito de representar a RMC da forma mais atual possível, para o sistema viário foram utilizados dados da plataforma OpenStreetMap, com dados disponíveis sob a Open Database License (ODbL) e sob controle da OpenStreetMap Foundation, fundação sem fins lucrativos. Os dados são abertos e a plataforma se define como uma iniciativa para criar e fornecer dados geográficos gratuitos, como mapas de ruas, para qualquer pessoa.

Foi realizada a comparação entre os mapas fornecidos pela OpenStreetMap e alguns mapas mais antigos e as bases se mostraram idênticas, com diferenças apenas em áreas de crescimento urbano, como é o caso dos novos loteamentos de Paulínia e Betel. Dessa forma, optou-se por trabalhar com os dados mais atualizados.

3 De acordo com Queiroga (2007), a megalópole "se constitui em uma rede urbana muito densa, conectando de forma bastante complexa diversas entidades urbanas (distritos, cidades, aglomerações urbanas e metrópoles), constituindo uma ampla conurbação funcional, não necessariamente uma conurbação física - ainda que esta seja frequente em vastas porções dos territórios megalopolitanos". E a "Megalópole do Sudeste do Brasil" é composta por São Paulo e as cidades do Rio de Janeiro, Campinas, São José dos Campos, Ribeiräo Preto e Sorocaba. 
Para extração das bases do OpenStreetMap, foi utilizado um plug-in online chamado BBBike Extract Service, que extraiu os dados definidos em shapes, lidos em QGIS e trabalhados em softwares de desenho e edição de imagem, para criação dos mapas temáticos que são utilizados em toda a pesquisa.

Para os limites de município e perímetro da RMC, os dados foram obtidos a partir do DataGEO, infraestrutura de dados espaciais ambientais do Estado de São Paulo. Os dados desta plataforma são provenientes, em sua maioria, dos órgãos públicos que compõem o Sistema Ambiental Paulista. Estes dados também foram comparados com os dados disponíveis do IBGE

Para os dados de uso do solo, foi utilizado o visualizador de informações espaciais da INDE - Infraestrutura Nacional de Dados Espaciais, órgão ligado ao governo federal e que disponibiliza informações municipais, estaduais e federais. Os dados relativos ao uso do solo são originais do IDE/SP - Infraestrutura de Dados Espaciais de São Paulo, vinculado à EMPLASA.

Todas as outras informações temáticas que constam dos mapas foram retiradas de fontes oficiais ou trabalhos acadêmicos e trabalhados sobre as bases cartográficas descritas acima. O principal material, no entanto tem origem nos relatórios que compõem o Plano de Desenvolvimento Integrado da Região Metropolitana de Campinas (PDUI da RMC), de 2018 em processo de elaboração pela EMPLASA (2018a).

\subsubsection{BREVE HISTORICO DA RMC}

Historicamente, o papel articulador da RMC se conforma a partir da cultura cafeeira, que foi o primeiro ciclo econômico a contribuir efetivamente com o desenvolvimento da região de Campinas, impulsionando a ocupação rural e urbana, pela instalação do sistema ferroviário e da promoção da migração estrangeira. Segundo Baeninger (1992, p.109), "desde fins do século XVIII, Campinas destaca-se no contexto estadual em função de seu dinamismo econômico. Sua posição geográfica privilegiada permitiu-lhe em diferentes momentos da história, servir de ligação entre o interior e a capital".

Campinas demonstrou destaque desde a época da cultura açucareira sendo considerada uma das principais produtoras de cana da Capitania (GONÇALVES e BAENINGER, 2000), o que a configurou como receptora de migrantes para trabalhar na lavoura e afirmou seu potencial na economia agrícola. Mas foi durante os períodos de cultura do café que Campinas adquiriu maior notoriedade. Junto com o café, expandiram-se, na região, diversos serviços atrelados a este tipo de economia, inclusive as condições relativas à mobilidade, primeiro com a instalação das ferrovias e depois com a substituição dessas pelas rodovias. Segundo Baeninger (1992), a cultura cafeeira, ao expandir para o oeste do estado, estruturou os centros urbanos articulados pela ferrovia, sendo essa articulação reforçada pelas rodovias, em momento posterior.

Com a crise do café, aproveitando-se das infraestruturas viárias instaladas na região, desenvolveram-se outras atividades agrícolas, além do setor industrial, que se deslocava da capital do estado através de um processo de descentralização desse setor. Essa alteração nos modos de produção intensificou a urbanização da região de Campinas e atraiu mão-de-obra gerando grande fluxo de pessoas vindas das áreas rurais, tanto da região próxima quanto de outros estados.

A instalação de indústrias e agroindústrias na região, na década de 1970 intensificou a conurbação de municípios e a estruturação do processo de metropolização. A política de abertura de novas estradas e a recuperação e melhoria das já existentes, além da localização do aeroporto de Viracopos, contribuíram para a expansão da mancha urbana, com a instalação de indústrias nas principais rodovias. (BAENINGER, 1992)

Segundo Queiroga (2007), este deslocamento do eixo de industrialização, com o apoio da indústria automobilística, forçou a construção de novas rodovias, estabelecendo assim uma nova lógica de localização industrial, 
contribuindo para o sucateamento das malhas ferroviárias.

Nesse contexto, de desenvolvimento, em que ocorre a descentralização da indústria da metrópole de São Paulo e a estruturação do sistema rodoviário, a região de Campinas passa por um processo de metropolização, reconhecendo o potencial de diversos municípios nos arredores da cidade como agentes econômicos importantes e atuantes no desenvolvimento industrial. Além disso, o aglomerado urbano de Campinas tem se destacado por possuir uma área industrial dinâmica, especialmente nos segmentos de indústrias de alta tecnologia, aumentando a sua participação no contexto estadual, com a instalação de novas fábricas nos setores de tecnologia.

O desenvolvimento de Campinas influenciou, assim, o desenvolvimento das cidades do entorno, com a extrapolação da instalação das indústrias na cidade sede. A presença das rodovias tem papel preponderante nesta lógica da RMC

De acordo com Bernardini (2017), os municípios da RMC conformaram uma rede urbana específica, com investimentos em infraestrutura advindas de outras esferas governamentais, como é o caso, por exemplo, da construção da Rodovia Dom Pedro I. Além disso, a partir da década de 70, são instalados parques industriais financiados pelo setor privado. Nessa movimentação, Campinas teve um papel primordial sobre a região, o que atraiu população e novos investimentos, induzindo a um movimento de extrapolação da cidade sede, em direção às cidades do entorno.

Ainda que Campinas tenha esse papel central na formação da região metropolitana, é característica desta região o fato de as cidades do entorno não estarem conurbadas a cidade sede, como ocorre com a Região Metropolitana de São Paulo. A ocupação por dispersão e fragmentação é o padrão da RMC, muito por conta do processo tardio de industrialização. Essa condição, segundo Bernardini (2017), a rede urbana da região de Campinas ganhou um outro caráter, no qual se sobressai a importância das pendularidades na dinâmica dos deslocamentos diários da população.

A utilização das rodovias como eixo de instalação das indústrias, também definiu o fluxo migratório existente na região. A concentração de indústrias nas cidades menores, com um processo de descentralização espacial dos investimentos industriais, acompanhado pela centralização dos serviços especializados nas metrópoles, proporcionou um fluxo de migração que não buscou a cidade sede.

Segundo o PITU 2015 (FECAMP, 2006), no ano 2000, Campinas não havia alcançado a população de um milhão de habitantes, enquanto as cidades do seu entorno já totalizavam 1,4 milhão. Isso demonstra a desconcentração populacional, que contribui para a dinamização e inclusão das cidades menores nas dinâmicas da região metropolitana. Mas, como fatores negativos dessa condição, podem ser apontados o compartilhamento de problemas locais com os municípios vizinhos, de abrangência regional, como, por exemplo, a expansão desordenada das áreas periféricas e, consequentemente, a alocação de população em áreas de riscos ambientais.

Devido aos processos de crescimento da cidade de Campinas, ocorridos anteriormente à sua metropolização, e que estimularam o surgimento de vários problemas relacionados à habitação e outras infraestruturas básicas de qualidade de vida, a população migrante passa a se deslocar para os municípios menores, nos arredores da cidade sede, em busca de algumas vantagens, como menor valor da terra e maior acessibilidade aos locais de trabalho industriais, que se concentram nos arredores das rodovias.

Esse movimento, no território, de ocupação das cidades menores ao redor de Campinas, incentivou a principal dinâmica atual da região, que são os movimentos pendulares e os deslocamentos intrametropolitanos, entre diversas cidades. Segundo Cunha et al. (2006), isso ocorre com a combinação entre a concentração do local de moradia nas cidades do entorno e a concentração das atividades produtivas na cidade sede, em particular aquelas ligadas aos setores de comércio, serviços e construção civil.

Todos esses processos, de descentralização da migração - que vai em 
direção às cidades do entorno da cidade sede -, da estruturação e atração das atividades econômicas por meio das rodovias e da ocupação dos espaços periféricos por diversos segmentos populacionais tiveram impacto na forma urbana, que se desenvolveu de forma dispersa, fragmentada no território da RMC.

\subsubsection{EVOLUÇÃO DA MANCHA URBANA DA RMC}

Segundo Nascimento (2016), a expansão da mancha urbana do município de Campinas tem origem a partir dos anos 1940 e 1950, com a instalação de grandes indústrias na região, fortalecendo a centralidade regional da cidade de Campinas. A partir dos anos 1960, as cidades ao redor passam a crescer com maior rapidez, até a década de 1990, sendo o período entre 1979 e 1989 o mais acelerado. Neste período, as áreas urbanas começam a se aproximar e os usos rurais entre elas passam a ser suprimidos e transformados em vazios, a espera de ocupação, ou seja, houve não apenas um crescimento urbano sobre terras já desocupadas, mas também em substituição das culturas agrícolas, como o café, a cana-de-açúcar e os citros.

Na década de 1950, houve um processo de expulsão da população mais pobre do centro urbano, deslocando-se para áreas mais distantes, incentivado pela aprovação de loteamentos e normas urbanísticas específicas, além da implantação de infraestrutura urbana, o que mostra que esses movimentos foram sancionados pelas ações e pelas omissões do poder público, conforme indica Miranda (2002). Nessa mesma época, nos municípios menores, a mancha urbana ainda se concentrava no núcleo central urbanizado, com alguns bairros ao redor.

Entre os anos de 1965 e 1979, segundo Nascimento (2016), houve um crescimento das áreas urbanizadas nos municípios do entorno de Campinas, motivado pela intensificação das migrações para a região e o progressivo aumento dos preços da terra urbana nas áreas adensadas da cidade sede. Dessa forma, a periferia do município passou a crescer extrapolando os limites municipais e colaborando com os processos de conurbação. No eixo norte da RMC, da SP-332, este período representou a ocupação urbana na porção norte do município de Campinas, na região do distrito de Barão Geraldo, que surge junto com a implantação do campus da Universidade Estadual de Campinas (UNICAMP), além de grandes loteamentos, muitas vezes dispersos pela área rural e pelas chácaras de recreio, que se localizavam ao longo da "Estrada da Rhodia", em direção a Paulínia. Além disso, houve o crescimento da área urbanizada no município de Paulínia, que esteve associado à inauguração da refinaria de petróleo (REPLAN), em 1972

A década de 1980 representou a consolidação dos dois processos principais de ocupação do território metropolitano, que caracterizam a região até os dias atuais. De um lado, a urbanização precária no vetor sudoeste e noroeste. De outro, a urbanização voltada às classes mais altas, no vetor sudeste. No eixo da SP-332, a dinâmica mais expressiva fo o crescimento de algumas cidades menores, com a busca de terras mais baratas

Nas décadas de 1990 e 2000, a implantação de novos loteamentos e dos condomínios foram os maiores impactos para a mancha urbana da RMC como um todo. Segundo Cunha et al. (2006), a expansão condicionada pela implantação de novos loteamentos ocorre em praticamente todos os municípios. Mas é importante destacar a importância dos condomínios residenciais horizontais e dos loteamentos fechados nesse processo, uma vez que eles acentuaram a segregação social, tanto na escala intraurbana quanto na metropolitana.

Além da questão habitacional, é importante ressaltar a implantação de empreendimentos comerciais de grande porte nas rodovias. Como indica Nascimento (2016), houve uma intensificação na instalação de grandes empreendimentos comerciais e multiuso em áreas próximas aos principais eixos rodoviários da região. Essas dinâmicas podem ser observadas na Figura 7, que mostra a evolução da mancha urbana da RMC, desde 1965 até 2015. 
(1)

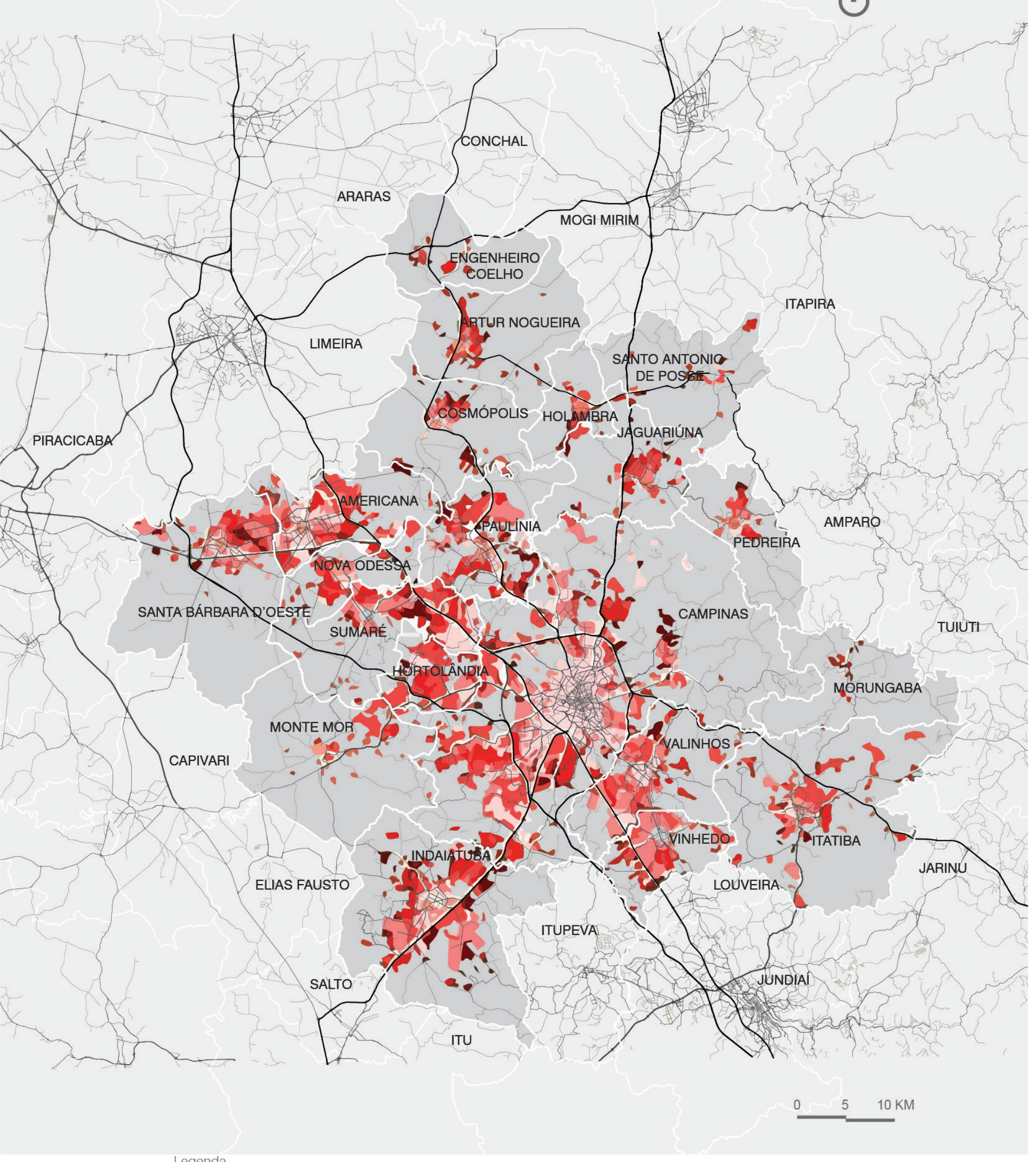

Legenda

1979

Fonte: Elaborado pelo autor | Fonte de dados: Nascimento, 2016

\subsection{ESPAÇOS DE VIDA NA RMC}

Para que seja feita a caracterização da RMC na escala intrametropolitana, é importante compreender como os espaços de vida da população metropolitana são organizados neste território. $\mathrm{Na} \mathrm{RMC}$, as formas de ocupação e o crescimento das cidades menores são fenômenos importantes na definição dos padrões dos espaços de vida. A migração na RMC ocorreu de forma distinta das metrópoles industriais, com a ocupação dos municípios no entorno da cidade de Campinas, o que manteve desconcentradas as dinâmicas populacionais

Assim, segundo Marandola (2008), Campinas possui menor participação relativa na população, na economia e na indústria, em relação à região metropolitana como um todo. A cidade recebe menor quantidade de migrantes que as cidades ao seu redor, o que configura, nesta relação, um saldo negativo de migração. Essas questões são evidenciadas, ainda, pela grande pendularidade da população na região e pela fragmentação dos tecidos urbanos e metropolitano.

Essa condição de dispersão da população gerou uma forma de habitar a metrópole bastante particular. Os espaços de vida da RMC estão dispersos por todas as cidades da região e, segundo Baeninger (2002), são raras as vezes em que as pessoas nascidas e criadas em uma cidade da região se mudem para a sede metropolitana, ainda que não trabalhem ou estudem na sua cidade de origem. Nesse caso, a mobilidade pendular substitui a migração, que é mais comum para a população que chega à região, em direção à cidade de Campinas, mas muda-se, nos anos seguintes para outra cidade da região.

Diante desse cenário, pode-se dizer que os espaços de vida da população metropolitana se localizam, na maior parte do tempo, nas cidades de origem da RMC, além da circulação pela região como um todo, dado que os sistemas de transporte e comunicação existem em grande quantidade na região - ainda que existam grandes problemas relacionados à operação dos transportes públicos coletivos. 
Marandola (2008) descreve a forma característica dos espaços de vida da RMC, em contraste com o tipo ideal para a metrópole industrial, que tem como exemplo a Região Metropolitana de São Paulo.

Diferente do tipo ideal para a metrópole industrial, onde prevalecia a dependência em relação à cidade sede, o que se observa na RMC e uma forte vinculação com a propría cidade natal. Quando e necessario, busca-se trabalho ou estudo em outras cidades, (...) com o estabelecimento de lugares na metropole. Contudo, nota-se (...) que a concentração do espaço de vida está na cidade natal. A gravitação em torno de Campinas ocorre de forma bastante fragmentada e seletiva, não prevalecendo o tipo ideal da metrópole industrial que obrigava a população a recorrer à cidade sede em busca de bens, serviços e lazer. É evidente que a hierarquização da rede urbana organiza as cidades e muitas coisas só serão encontradas em Campinas. Contudo, é menor o grau de dependência orgânica (ou seja, para as tarefas do dia-a-dia) do que se costuma
atribuir. (MARANDOLA, 2008, p.189)

Assim, como exemplo das dinâmicas peculiares da dispersão urbana da RMC, Reis (2006) identifica a existência de um sistema part-time próprio da região, que consiste na multiplicidade de deslocamentos diários pela região. Exemplos dessa condição, são os médicos que possuem consultórios em diversas cidades da região e nelas permanecem por um ou dois dias, revelando que nessa dinâmica não são os pacientes que se deslocam, como seria mais comum, ou, ainda, os professores, que realizam deslocamentos metropolitanos diários, entre várias escolas ou universidades, em cidades diferentes.

Esses exemplos destacam, segundo Reis (2006), a tendência à organização coletiva de serviços para grupos de usuários não estão ligados aos sistemas públicos de transporte, como é o caso dos ônibus e vans fretados. Esses sistemas alternativos acontecem através dos espaços de mobilidade da metrópole, principalmente as rodovias.

Além de servirem como base para os deslocamentos, as rodovias, sobre as quais se estrutura o padrão de urbanização da RMC conectando não apenas as manchas urbanas consolidadas, mas as áreas de espraiamento, também concentram estabelecimentos comerciais e de serviços. Essa situação é um importante índice da metropolização das atividades cotidianas, uma vez que estas passam a servir a toda a população metropolitana, sem necessariamente estar vinculada à cidade sede ou outra cidade específica. Ainda de acordo com Reis (2006), é importante destacar os grandes estabelecimentos de consumo, como os hipermercados, shopping centers e atacadistas, que se localizam próximos às rodovias como forma de garantir a maior acessibilidade dos consumidores das cidades da região e da população que habita as áreas dispersas. Desta forma, conseguem se consolidar como grandes centros de consumo, tanto na escala intraurbana quanto regional.

Mas essa condição de dispersão da população e fragmentação da mancha urbana também traz problemas à RMC, como, por exemplo, a segregação socioespacial da população, representada pela implantação de condomínios de alta renda e dos loteamentos fechados, e a alta especulação imobiliária que ocorre nos vazios entre as áreas de ocupação dispersa, conforme aponta Nascimento (2013).

O Plano de Desenvolvimento Urbano Integrado da RMC (PDUI RMC), desenvolvidopelaEMPLASA(2018a), aponta outras questões problemáticas que acompanham essa forma de ocupação do território e de dinâmica populacional, como a ocupação das áreas de preservação ambiental, a substituição da agricultura por espaços livres de especulação imobiliária e a expulsão da população mais pobre para áreas sem infraestrutura, longe dos núcleos urbanos consolidados, dado acréscimo dos valores da terra nas áreas centrais dos municípios. O plano destaca, ainda, o impacto da Rodovia Anhanguera na configuração do território, que separa a parcela mais estruturada da região das áreas de precariedade, em expansão. Dessa forma, é possível reconhecer um sistema de segregação que extrapola o modelo centro-periferia.

Assim, como aponta o PDUI (EMPLASA, 2018a), as rodovias de forma geral, além de serem os elementos principais na dispersão urbana, são importantes na compreensão da distribuição demográfica no espaço metropolitano. De acordo com Nascimento (2013, p.103), 
Outro importante traço da distribuição demográfica no espaço urbano-metropolitano campineiro é a influência do traçado rodoviário e sua disposição em escala intraurbana que tende, cada vez mais, a consolidar uma "dispersão concentrada" de grandes volumes de população para setores específicos das cidades. Fenômeno iniciado com a ocupação ao longo da Via Anhanguera, atualmente, em um número cada vez maior de municipios, as rodovias vêm sendo utilizadas como vetores de localização de bairros de ocupação urbana adensada, em sua maioria, concentrando populações de médio e baixo status. Entre as provaveis causas desse adensamento em areas perifericas estáo a implementaçăo de medidas para desestimular a implantação de novos loteamentos, realizada a partir dos anos 1990 por algumas prefeituras da RMC, (...) bem como o expressivo aumento, em toda a regiáo, do parcelamento de glebas para a produção de condominios e loteamentos fechados.

As rodovias, portanto, passam a ter uma relevância maior que apenas eixos de deslocamento, tornando-se endereço de grande parte da população que habita a RMC. São, assim, seu lugar de moradia, seu lugar de trabalho, ou apenas espaço de passagem.

\subsubsection{A IMAGEM DA RMC}

No cenário da dispersão e da fragmentação da RMC, descrito anteriormente, faltam imagens que representem as cidades que a compõem, conferindohes identidades ou referências para seus habitantes, o que seria essencial na apropriação dos seus espaços públicos pela sua população. De acordo com Marandola (2008, p.249)

\begin{abstract}
Se não há uma construção simbólica, os pedaços do urbano espalhados tendem a não se conectar à cidade. As cidades da RMC carecem de ícones urbanos, de paisagens reconhecidas como imagem da cidade. O centro não possu espaços públicos com força imagética que extrapole suas cercanias. Embora todas tenham praças que convidam a permanência, a centralidade não é expressiva a ponto de marcar um grande espaço público de encontros. Mesmo para os moradores da cidade, perguntar sobre a imagem da cidade ou sua paisagem nâo colhe muitas expressões significativas. Não há uma imagem forte projetada pelas proprias cidades, mas apenas aquelas que são projetadas de fora dela e que, por serem pejorativas, não são reconhecidas.
\end{abstract}

No entanto, é possível dizer que as rodovias, em certa medida, cumprem com essa função, visto que os espaços de vida da RMC são estruturados por elas, como mostrado anteriormente. O fato de a circulação da população entre cidades (ou entre os espaços fragmentados), acontecerem nestes espaços, transforma as rodovias em elementos que se destacam na imagem do território, ou no imaginário da população que ali habita.

Segundo Marandola (2006), que se debruça sobre a Rodovia Anhanguera, ainda que a rodovia não tenha uma imagem confortável, adquiriu mais funções no cotidiano do que foi previsto na sua construção. Ela não só teve um papel central na estruturação dos espaços urbanos da região mas também, atualmente, compõem e estrutura os espaços de vida da população metropolitana. Essa condição faz com que seu uso extrapole sua função original.

Sua caracteristica de Via não tinha o objetivo de realizar ligaçôes locais, mas a expansáo das cidades e a própila ocupação de suas margens fez com que mais pistas de olagem e marginais fossem necessárias, assim como acessos, viadutos e passarelas. A Anhanguera hoje não apenas a principal rodovia de ligação da capital com 
interior, mas é também a principal "avenida" da RMC. A paisagem é intensa e agressiva. O deslocamento implica riscos constantes. (MARANDOLA, 2008, p.129)

Essa mesma lógica pode ser transferida às outras rodovias que compõem a RMC. Todas são responsáveis pela estruturação original dos seus eixos, mas também são utilizadas como trajetos diários pela população. Nesse sentido, pode-se dizer que suas paisagens são características, principalmente pelas diferentes formas de ocupação do seu entorno. A Rodovia SP-332, por exemplo, tem como peculiaridade a presença da REPLAN, Refinaria da Petrobrás como um ponto de referência, com suas chaminés e os gigantescos dispositivos de armazenamento, conforme mostrado na Figura 7

No entanto, é importante destacar, ainda, que cada trecho de uma mesma rodovia possui uma referência distinta, uma paisagem que a define. $\mathrm{Na}$ própria SP-332, por exemplo, no trecho próximo à cidade de Cosmópolis, a intensa plantação de cana-de-açúcar e a represa do rio Pirapitingui, de abastecimento da cidade, são elementos de destaque da paisagem, como mostrado na Figura 8, que se contrapõe ao cenário industrial da mesma rodovia na região de Paulínia.

Figura 8: Tanques de combustível da REPLAN, em Paulínia
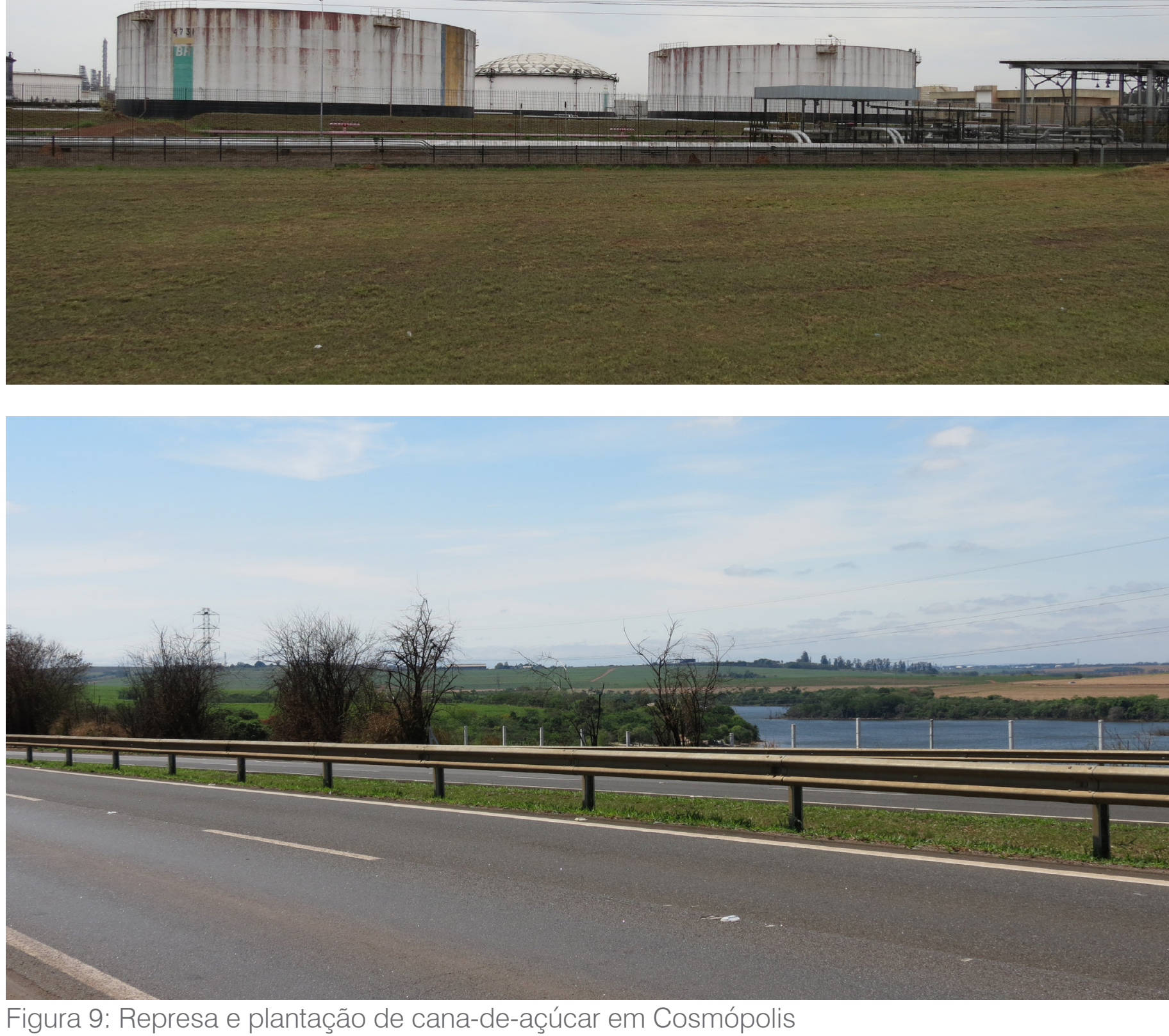


\subsection{AS RODOVIAS DA RMC}

Dada a importância do sistema viário na estrutura das diversas dinâmicas da RMC, nas suas diversas escalas, sejam elas intraurbanas intrametropolitanas ou regionais, a seguir serão apresentadas as rodovias que compõem o cenário da RMC, indicando suas principais funções e conexões, demonstrando as múltiplas relações possíveis. Será destacada a SP-332, que é o eixo de estudo desta pesquisa.

\subsubsection{AS RODOVIAS}

Segundo a EMPLASA (2009) e AGEMCAMP (FUNDAP, 2010), as rodovias da RMC podem ser setorizadas da seguinte forma: sistema viário estruturante, composto pelas rodovias principais e pelas secundárias, e sistema viário complementar.

As vias principais são as que permitem o acesso à RMC por meio da conexão com outros Estados e outros polos importantes para o Estado de São Paulo. As secundárias têm importância regional, dentro da própria região metropolitana, na conexão entre os municípios que a compõem. Já o sistema complementar são as vias que cruzam a RMC, fazendo conexão com municípios menores, próximos à região metropolitana. A Figura 10 mostra a localização de todas as rodovias que compõem a região.

\section{Rodovias principais}

As Rodovias Anhanguera e Bandeirantes são as duas rodovias com maior relevância para a RMC, sua formação e estruturação. Elas permitem a conexão com as Regiões Metropolitanas de São Paulo e da Baixada Santista, com o Rodoanel Mário Covas, e com o interior do Estado de São Paulo, em direção à Ribeirão Preto, até os Estados de Minas Gerais e Goiás.

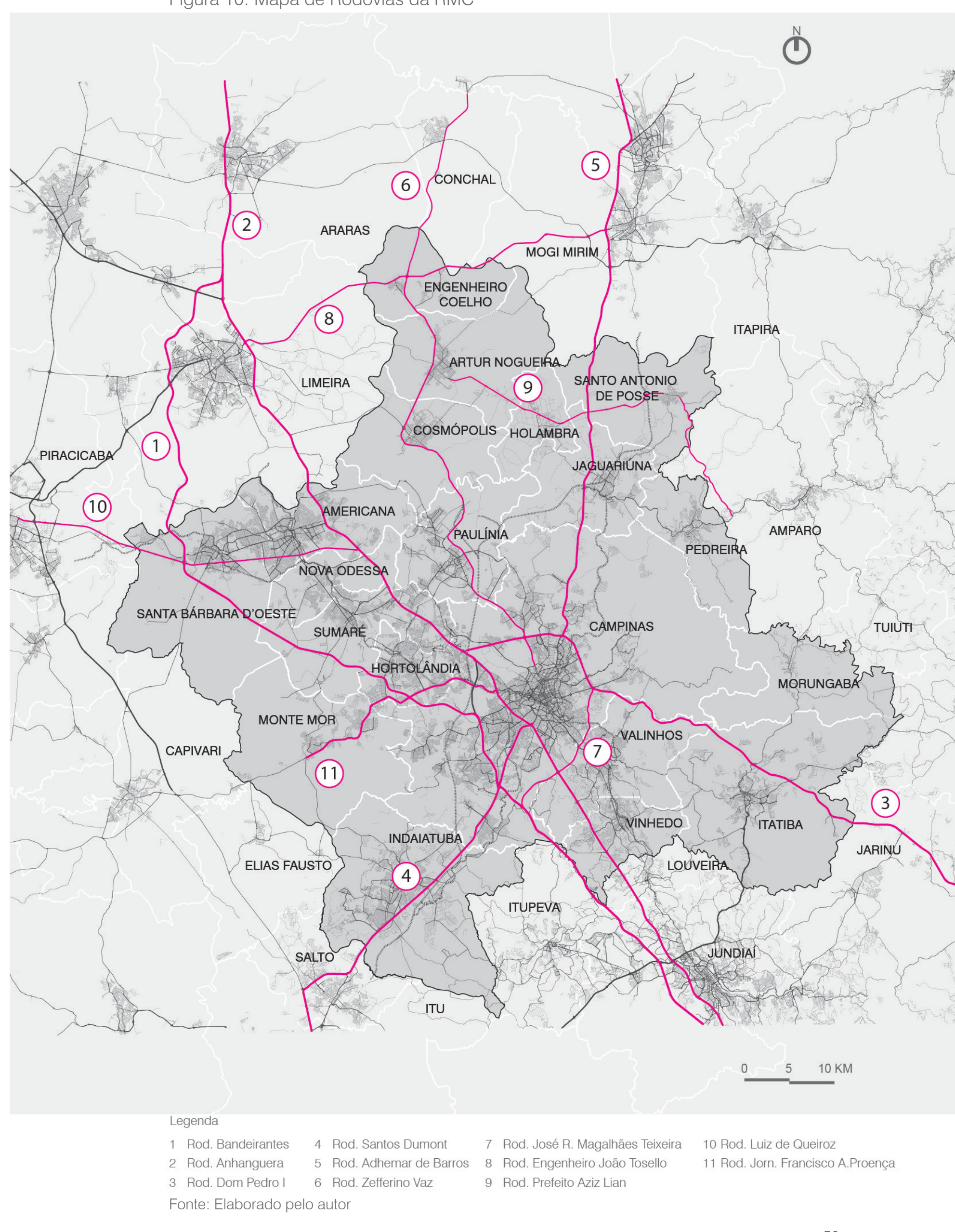




\section{Rodovias secundárias}

O Anel rodoviário Roberto Magalhães Teixeira conecta a Rodovia Dom Pedro I com a Rodovia Anhanguera, fechando um anel viário em torno do município de Campinas.

Já a Rodovia Professor Zefferino Vaz, a SP-332, faz a conexão entre as cidades do eixo norte com a cidade de Campinas, cruzando com a Rodovia Dom Pedro I. Por sua importância nesta pesquisa, ela será caracterizada com mais atenção mais à frente, neste capítulo

\section{Sistema viário complementar}

As rodovias do sistema viário complementar são diversas, como a Rodovia Jornalista Francisco Aguirra Proença que conecta Monte Mor, Hortolândia, Sumaré e Nova Odessa e a Rodovia Luiz de Queiroz, que conecta Santa Bárbara D’Oeste e Anhanguera.

No entanto, para esta pesquisa, as mais importantes são as que se relacionam com o eixo norte da RMC. São elas, as Rodovias Engenheiro João Tosello e Prefeito Aziz Lian. A primeira faz conexão de Engenheiro Coelho com as Rodovias Adhemar de Barros e Anhanguera, passando por cidades vizinhas à RMC, Limeira e Mogi Mirim. Já a segunda, faz a conexão das Rodovias Adhemar de Barros e Professor Zefferino Vaz, passando pelas cidades de Artur Nogueira e Holambra.

\subsubsection{A SP-332 - RODOVIA PROFESSOR ZEFFERINO VAZ}

Espinha dorsal desta pesquisa, a SP-332 se inicia na região norte do município de Campinas, como continuidade das Ruas Funilense e Carolina Florence e se estende até o município de Mogi Guaçu, já fora da Região Metropolitana de Campinas. Segundo a concessionária Rota das Bandeiras ${ }^{4}$, que faz a gestão desta rodovia, ela foi inaugurada em 1981, e possui 81 km de extensão. As cidades pelas quais ela passa são: Campinas, Paulínia, Cosmópolis, Artur Nogueira, Engenheiro Coelho, última da RMC, Conchal e Mogi Guaçu. Dá também acesso ao distrito de Barão Geraldo, onde estão localizadas a Universidade Estadual de Campinas (UNICAMP) e a Pontifícia Universidade Católica de Campinas (PUCC), e ao polo petroquímico de Paulínia, por meio de trecho conhecido como "Tapetão".

A SP-332 se configura como eixo de intenso tráfego intrametropolitano, como suporte de migração pendular atraída por dois municípios: Paulínia e Holambra. As empresas do polo petroquímico e as fazendas de flores têm promovido deslocamentos de trabalhadores, seja por meio de ônibus fretados, seja por linhas convencionais, urbanas e intermunicipais, que movimentam passageiros de Campinas, Cosmópolis, Artur Nogueira, Engenheiro Coelho e Conchal. A estes deslocamentos devem-se acrescentar aqueles de estudantes que se movimentam de um município a outro da região, atraídos por escolas conceituadas, de primeiro a terceiro grau, como é o caso de Campinas e Engenheiro Coelho, intensificando o tráfego de peruas e veículos individuais, além de ônibus fretados e de linha. Embora não se registre nessa região o processo de conurbação, a intensidade desta migração pendular merece destaque na estruturação da forma urbana e das dinâmicas da rodovia

A SP-332 hoje se encontra quase totalmente duplicada, restando, com pista simples, apenas os trechos entre Engenheiro Coelho e Conchal,

$4 \quad$ Disponível em: http://www.rotadasbandeiras.com.br Acesso em 12 jun. 2019 
atualmente em obras, e Conchal e Mogi Guaçu. E pedagiada na altura do município de Cosmópolis, em ligação com Paulínia. A implantação do pedágio é, ainda, bastante questionada pelos moradores da cidade de Cosmópolis, visto que a rodovia é a única forma de acessar a cidade de Paulínia. E como indicado anteriormente, estas relações entre cidades vizinhas são de grande importância na dinâmica da região. No caso de Cosmópolis, por exemplo, o acesso ao hospital de Paulínia, cidade com mais recursos financeiros, é imprescindível, dificultado pela implantação de pedágio, aumentando os custos de deslocamento da população.

Para a travessia de pedestres e ciclistas, a Rodovia SP-332 apresenta no total, doze passarelas, distribuídas entre cada cidade que a margeia exceto em Engenheiro Coelho, além das áreas de maior ocupação, principalmente das indústrias.

\subsection{A CONFIGURAÇÃO EM VETORES}

As rodovias da RMC têm configuração radial, o que permite que a região seja dividida em vetores de ocupação, crescimento e desenvolvimento, mostrados na Figura 11 e que serão apresentados a seguir. São oito os vetores que a compõem, conforme classificação do Sistema Viário de Interesse Metropolitano (SIVIM). O SIVIM é um programa do Governo do Estado de São Paulo, que tem como intuito desenvolver estudos, projetos e ações, implantados de forma individual ou em parceria com municípios e entidades afins, para otimizar a operação dos viários de interesse metropolitano. A Empresa Metropolitana de Transportes Urbanos de São Paulo (EMTU/SP), é a responsável pela elaboração dos estudos sobre o viário das regiões metropolitanas do Estado, além da sua constante atualização

Destes oito vetores, sete deles se conformam em formato radial, com núcleo representado pelo centro do município de Campinas, que compõe

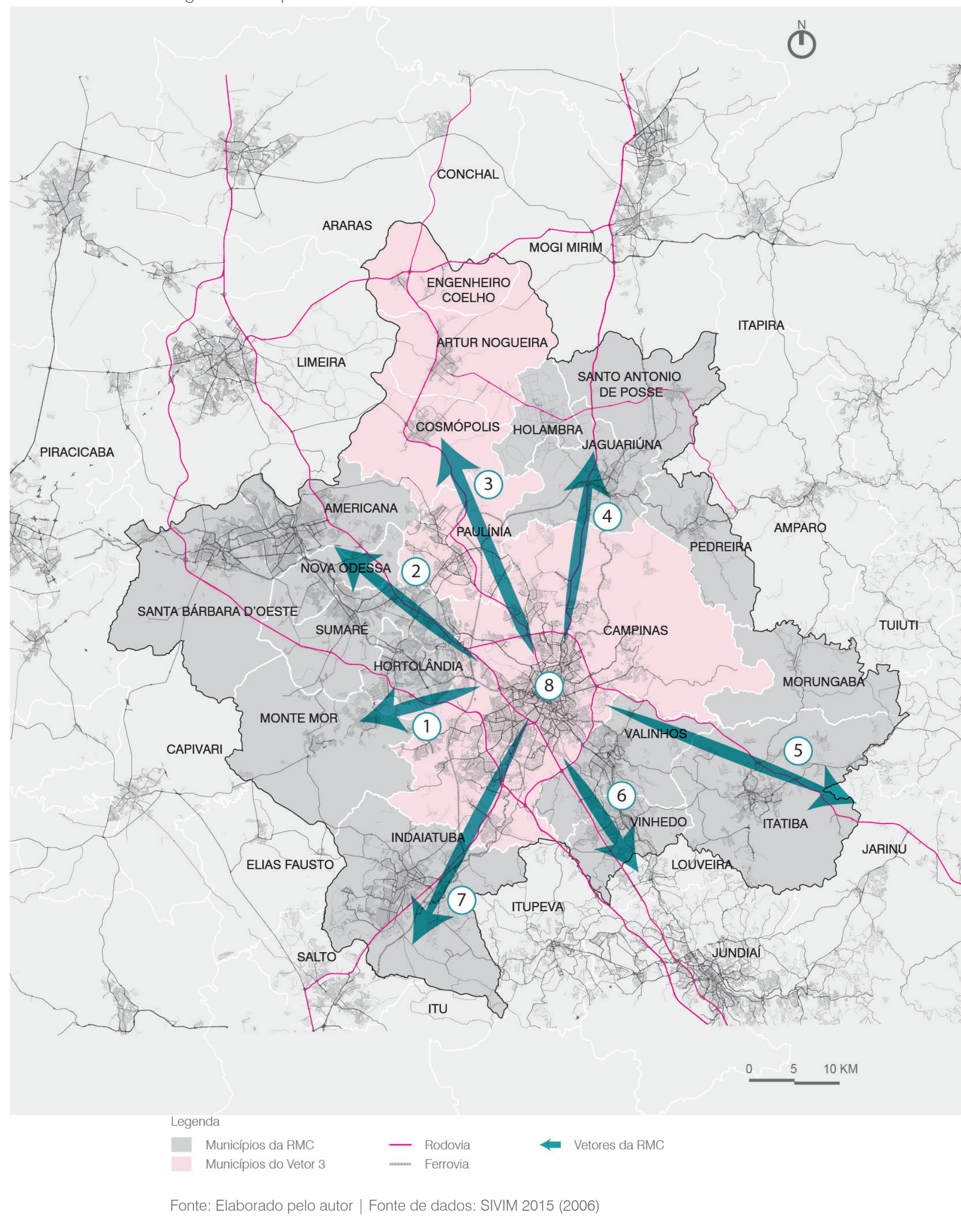


o oitavo vetor. Segundo Pires (2007), o recorte territorial que foi adotado para essa forma de caracterização da RMC baseia-se no agrupamento de zonas estabelecidas na Pesquisa Origem-Destino da RMC de 2003, elaborada pela EMPLASA. A identificação dos vetores ocorreu tanto em função da relação dos municípios com as principais rodovias de acesso ao centro metropolitano quanto pelas características socioeconômicas e de expansão urbana. Essa divisão permite compreender de forma bastante clara as dinâmicas principais da RMC

Segundo o SIVIM, os vetores possuem as seguintes características:

\section{VETOR 1 - Eixo Sudoeste/Noroeste: Monte Mor}

Composto pela Rodovia Jornalista Francisco Aguirre Proença, este eixo possui um crescimento populacional acentuado, com elevada taxa de crescimento médio anual da sua população. Mantém-se com perfil de município dormitório, abrigando uma população que trabalha e/ou estuda na cidade de Campinas.

VETOR 2 - Eixo Sudoeste/Noroeste: Hortolândia, Sumaré, Nova Odessa, Americana, Santa Bárbara D’Oeste

Conformado pela Rodovia Anhanguera, este vetor tem como características a consolidação da ocupação através do adensamento de vazios e da intensificação da conurbação, a subcentralidade do município de Americana e a função de principal eixo de concentração de atividades econômicas (industriais, comerciais e de serviços) da RMC, concentrando população de baixa renda, muitas vezes residindo em favelas e ocupações ilegais.

VETOR 3 - Eixo ao longo da SP-332: Paulínia, Cosmópolis, Artur Nogueira, Engenheiro Coelho

Vetor foco desta pesquisa, tem como principais características um dinamismo no crescimento populacional, iniciado na década de 1990 com elevadas taxas de crescimento e tendência de absorção de imigrantes, expansão da mancha urbana através da pulverização das suas áreas, tendência de incorporação de áreas para uso urbano a partir de loteamentos e condomínios fechados, principalmente entre a Rodovia Zefferino Vaz (SP-332) e a Estrada da Rhodia, e a expansão urbana com características de ocupação por população de baixa renda, em direção oposta à cidade de Campinas.

No item seguinte, serão detalhadas algumas questões essenciais deste vetor, como as suas dinâmicas populacionais e de mobilidade, além dos seus usos e ocupação principais.

VETOR 4 - Eixo ao longo da Rodovia Adhemar de Barros: Holambra, Jaguariúna, Santo Antônio de Posse, Pedreira

Formado pela Rodovia Adhemar de Barros, é composto por pequenos municípios recentemente incorporados à dinâmica metropolitana, sendo um eixo preferencial na implantação de indústrias de alta tecnologia e de condomínios de alta renda, como o Alphaville.

VETOR 5 - Eixo ao longo da Rodovia Dom Pedro I, direção Itatiba: Distritos de Joaquim Egídio e Sousas, parte de Valinhos e Itatiba

Este vetor é conhecido pela sua destacada qualidade ambiental, uma vez que grande parte do território constitui Área de Proteção Ambiental com a presença de áreas agrícolas ainda produtivas. A expansão urbana é bastante espraiada, com predomínio de empreendimentos residenciais de alto padrão, com taxa de crescimento médio superior à média regional

\section{VETOR 6 - Eixo na direção de Valinhos e Vinhedo}

Estruturado por uma estrada paralela à Rodovia Anhanguera, possui, em Campinas, ocupação urbana com predomínio de padrão médio, médiobaixo, com o surgimento de verticalização no período mais recente. Em 
Valinhos e Vinhedo, existe um predomínio de loteamentos fechados, destinados a população de maior poder aquisitivo, muitas vezes empregada no município de São Paulo.

\section{VETOR 7 - Eixo ao longo da Rodovia Santos Dumont direção Indaiatuba}

Este vetor possui elevada taxa de crescimento populacional, com incremento da mancha urbana superior a 50\%. A população de baixa renda está localizada em loteamentos populares e conjuntos habitacionais localizados na porção sudoeste do município de Indaiatuba, que possu tendência de ocupação através de condomínio e loteamentos fechados. Este vetor abriga concentração fabril de importância regional, com grande potencial de crescimento de atividades econômicas notadamente industriais, devido, principalmente, à localização do Aeroporto de Viracopos e a ligação com a região de Sorocaba.

\section{VETOR 8 - Área delimitada pelas vias Anhanguera, Dom Pedro e Anel Viário: Centro Metropolitano, Campinas}

Único vetor não radial, é composto por uma área com grande concentração de empregos, verticalização acentuada em algumas regiões, especialmente no Centro e Cambuí e tendência de evasão populacional, com taxa de crescimento negativa

\subsection{CARACTERIZAÇÃO DO VETOR 3}

Assim como apresentado anteriormente, a Rodovia SP-332 é o objeto desta pesquisa e, conforme classificação do SIVIM, esta rodovia articula o Vetor 3, que será o recorte territorial adotado. O vetor é composto por cidades com menos de 100.000 habitantes e crescimento populacional em alta, na última década. As cidades que o compõem, além da cidade sede, Campinas, são Paulínia, Cosmópolis, Artur Nogueira e Engenheiro Coelho (Figura 12)

Excetuando-se Campinas, a cidade de Paulínia representa a maior potência econômica desta região. A presença da REPLAN, refinaria da Petrobrás, desde os anos 1970, e sua proximidade com o polo tecnológico da RMC a eleva ao posto de cidade mais rica deste vetor, com PIB de $\mathrm{R} \$ 314.637,69$ e salário médio mensal de 4.8 salários mínimos, segundo dados do IBGE ${ }^{5}$. Também é a cidade mais populosa do Vetor 3, com projeção de 109.424 habitantes para 2019.

Em Paulínia está localizado o distrito de Betel, que conecta Paulínia ao distrito de Barão Geraldo por meio da Estrada Rhodia. Essa conexão entre distritos possui grande importância na formação do cenário de dispersão urbana do Vetor 3 e apresenta impacto nas análises que são realizadas nesta pesquisa

Cosmópolis é o segundo maior município do Vetor 3, com população estimada para 2019 de 72.252 habitantes. Em comparação com Paulínia seu PIB é bastante inferior, de $\mathrm{R} \$ 19.396,97$. A população, em relação a Paulínia, também é de mais baixa renda, com o salário médio mensal era de 2.7 salários mínimos. A economia da cidade se baseia na produção de cana-de-açúcar e nas indústrias químicas e farmacêuticas, instaladas no distrito industrial, próximo ao município de Paulínia. Além disso, possui área industrial no eixo em direção ao município de Artur Nogueira. 


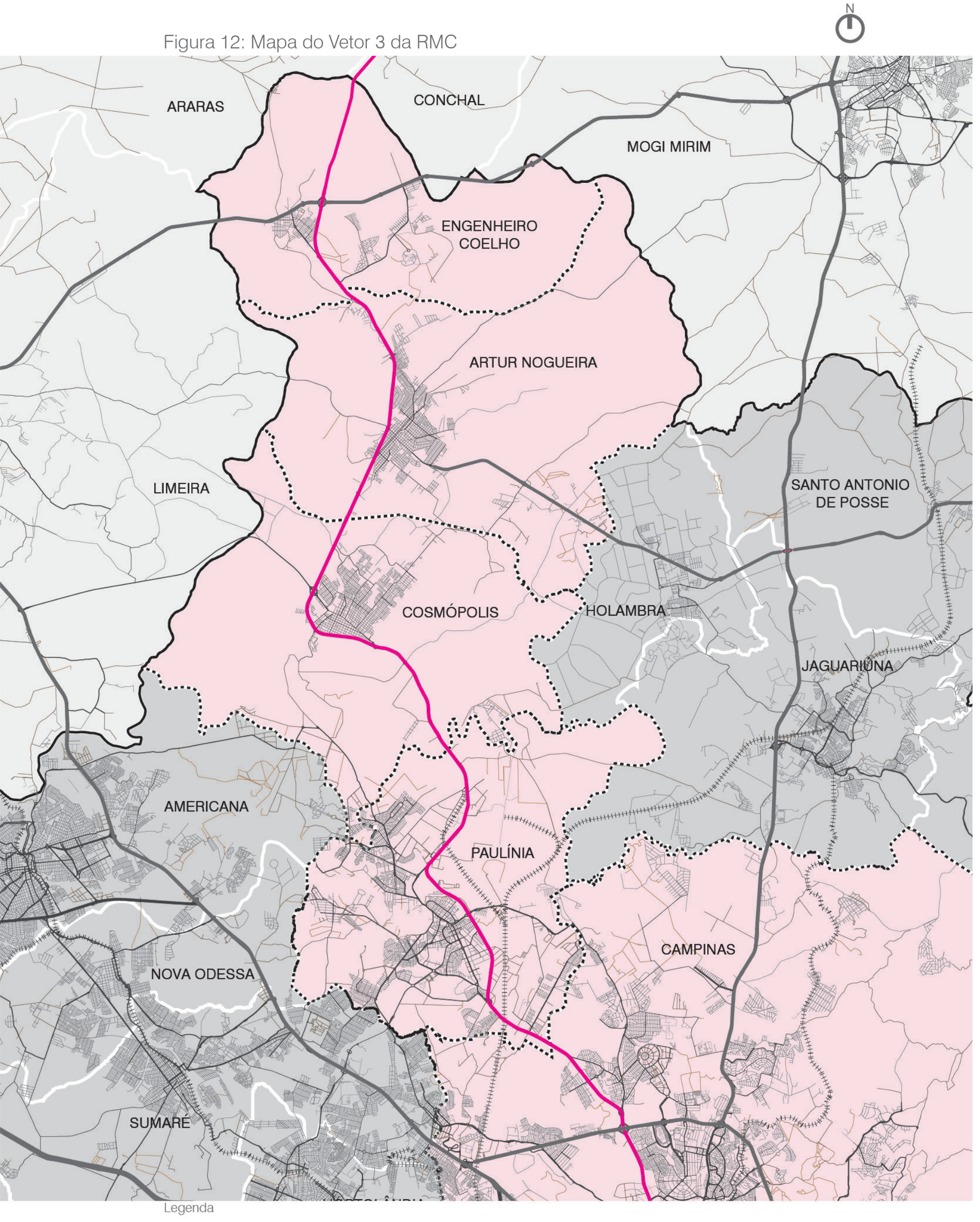

- Municíios da RMC

Municíios do vetor 3 da RMC

- Perímetro da RMC

Fonte: Elaborado pelo auto
-... Limite dos municípios do vetor 3

0
O município de Artur Nogueira tem população projetada para 2019 de 54.408 pessoas, superando apenas Engenheiro Coelho, e PIB de $\mathrm{R} \$ 19.388,74$, com salário médio mensal de 2.6 salários mínimos, dados muito próximos da realidade de Cosmópolis. Sua economia é baseada em indústrias do ramo têxtil e de produção de peças automotivas, em conjunto com a produção agrícola ancorada na laranja, além do setor de serviços.

Já Engenheiro Coelho tem população projetada de 20.773 pessoas, sendo a menor cidade do vetor, em termos populacionais. Ainda assim seu PIB é o segundo maior, de R\$23.074,63, com salário médio mensal era de 2.8 salários mínimos, ficando atrás apenas de Paulínia. Também é o município mais novo do vetor, com fundação em 1991. A economia da cidade baseia-se na agricultura, destacando-se a produção de laranja e de cana-de-açúcar, e também na indústria, voltada à produção agrícola e de peças automotivas. É destaque no município a presença do Centro Universitário Adventista de São Paulo (UNASP), que atrai estudantes de toda a região, incluindo municípios de fora da RMC.

Ainda que apenas parte da região norte do município de Campinas tenha relações diretas com o Vetor 3 , é importante ressaltar suas características, de forma geral, como parâmetro de comparação com as outras cidades do vetor. Campinas, portanto, possui população projetada pala 2019 de 1.204.073 habitantes, PIB per capita de $\mathrm{R} \$$ 49.876,62 e salário médio de 3.8 salários mínimos. É importante destacar, ainda. que Campinas tem, como representante neste eixo, o distrito de Barão Geraldo, no qual estão localizadas duas das principais universidades da região, a UNICAMP e a PUCC, além de ser parte do polo tecnológico da região.

Em relação à paisagem urbana, as cidades que compõe o Vetor 3 estão em processo de ocupação e dispersão, apresentando alguns núcleos urbanos em áreas rurais, mas com predominância de uma ocupação mais concentrada. São quase totalmente horizontais, com pontos muitos específicos de verticalização. Nenhuma delas apresenta pontos de referência ou imagens que as representem, como indicado anteriormente. 
Paulínia configura uma exceção, pois em termos de paisagem e ocupação urbanas, é bastante diferente das outras três cidades. Possui maior dispersão da mancha urbana, com potencial conurbação com a cidade de Campinas, ainda em processo de desenvolvimento. Também, apresenta maior verticalização, ainda que seja predominantemente de ocupação horizontal, com forte presença de grandes vazios nas áreas intraurbanas. Além disso, Paulínia tem tentado criar uma identidade da cidade, com a implantação de alguns elementos arquitetônicos, como é o caso dos portais de entrada ou do polo cinematográfico.

Segundo Marandola, Guedes e Silva (2010), o Vetor 3 possui cidades bem integradas às dinâmicas metropolitanas, embora a maior parte delas esteja mais ligada às dinâmicas rurais, como é o caso das cidades de Cosmópolis, Artur Nogueira e Engenheiro Coelho, que possuem lógicas diferentes de ocupação, em relação à cidade de Paulínia. No entanto, em relação ao crescimento populacional, Nascimento (2016) indica que na região norte, algumas cidades também apresentaram expressiva expansão de suas áreas urbanizadas, como por exemplo Cosmópolis e Artur Nogueira, o que reflete que há a dispersão da população resultante da busca por habitação e custo de vida mais baratos, em comparação com a oferta de Campinas e Paulínia, por exemplo.

Para o município de Paulínia, a presença da REPLAN foi um dos motivos da tardia ocupação do seu território, segundo Pires (2007). Na década de 1970, essa área era considerada como segurança nacional, o que conteve a expansão urbana até a década de 1980. É importante lembrar que a REPLAN e o polo petroquímico de Paulínia eram os principais motivos da expansão dessa área, com característica predominantemente popular ocupando espaços opostos à cidade de Campinas.

As diferenças, no entanto, não estão apenas nas formas e condições de ocupação de cada município, mas também nas suas múltiplas relações: entre o município com a cidade sede, entre os próprios municípios, com as dinâmicas intrametropolitanas gerais e com os municípios vizinhos à RMC. É possível dizer que existem relações diferentes entre os trechos de
Paulínia e Campinas e de Cosmópolis e Artur Nogueira, ou Artur Nogueira e Engenheiro Coelho, ainda que todos sejam estruturados pela SP-332.

De acordo com Marandola (2008), nem todas as cidades da região possuem o mesmo grau de integração ou metropolização. Essa condição é vinculada à sua história e participação nos processos de metropolização e os caminhos tomados a partir dela. Cosmópolis e Paulínia, embora demonstrem importante crescimento, permanecem com uma participação intermediária no processo de metropolização, sendo que Paulínia integrase mais à dinâmica metropolitana, dada a presença do polo petroquímico e pelas relações históricas que mantém com Campinas. Já Cosmópolis permanece mais distante do centro metropolitano, como um todo.

Artur Nogueira e Engenheiro Coelho são municípios com menor articulação com as dinâmicas metropolitanas, relacionando-se com Campinas mais como polo regional, ainda que o sistema de transporte seja o mesmo que das outras cidades. Uma das justificativas para essa menor participação está na dinâmica econômica destes municípios, com bases rurais e na proximidade com a cidade de Limeira, que, pela maior proximidade, cumpre com as funções da cidade sede.

A proximidade de Paulínia com a cidade sede e com as áreas de implantação do polo tecnológico, faz com que absorva dinâmicas específicas dessas áreas. Segundo Nascimento (2016), a expansão urbana de Campinas em direção ao distrito de Barão Geraldo tem provocado o transbordamento para a cidade de Paulínia, visto que a sua prefeitura tem oferecido incentivos para a implantação de loteamentos de padrão mais elevado, seguindo a tendência de ocupação de Barão Geraldo.

Esse crescimento tende a iniciar um movimento de conurbação entre Paulínia e Campinas, através da Rodovia SP-332. A incorporação do distrito de Betel ao município de Paulínia, nos anos 1990, evidencia a evolução da integração entre essas áreas, uma vez que apresenta, atualmente, crescimento baseado em condomínios fechados de alto padrão, da mesma forma e na mesma intensidade como ocorreu em Barão Geraldo. 


\subsubsection{ZONEAMENTO E USO E OCUPAÇÃO NO VETOR 3}

O PDUI da RMC organizou os zoneamentos vigentes de todas as cidades que compõem a RMC, como forma de análise das políticas de desenvolvimento dos municípios, como mostrado na Figura 14

Para o Vetor 3, é importante destacar que cada município tem legislação específica para o zoneamento, desvinculada das políticas dos municípios vizinhos, como é possível perceber em relação às áreas ainda não urbanizadas de Paulínia e Cosmópolis. Paulínia considera suas áreas livres como áreas urbanas de expansão e desenvolvimento, enquanto Cosmópolis considera estas mesmas áreas como de atividade rural. $\mathrm{Na}$ Figura 13, observa-se que, ainda que o zoneamento seja diferente, estas áreas são bastante similares, em termos de ocupação atual ou relação entre urbano e rural.

Ainda que tenha relação com a questão econômica de cada município, diferentes entre si, é importante destacar a predominância da delimitação

Figura 13: Foto aérea do limite de Município entre Paulínia e Cosmópolis

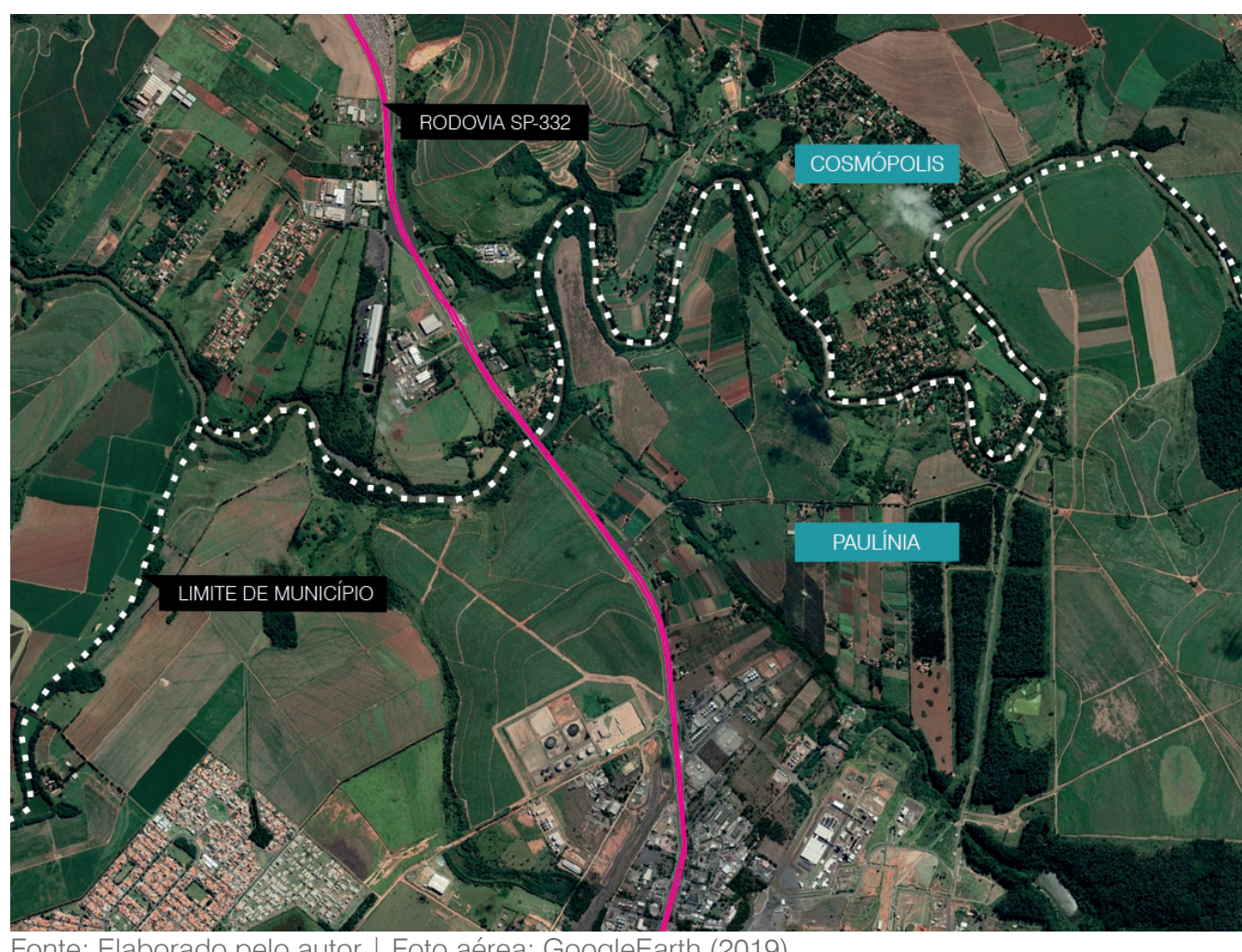

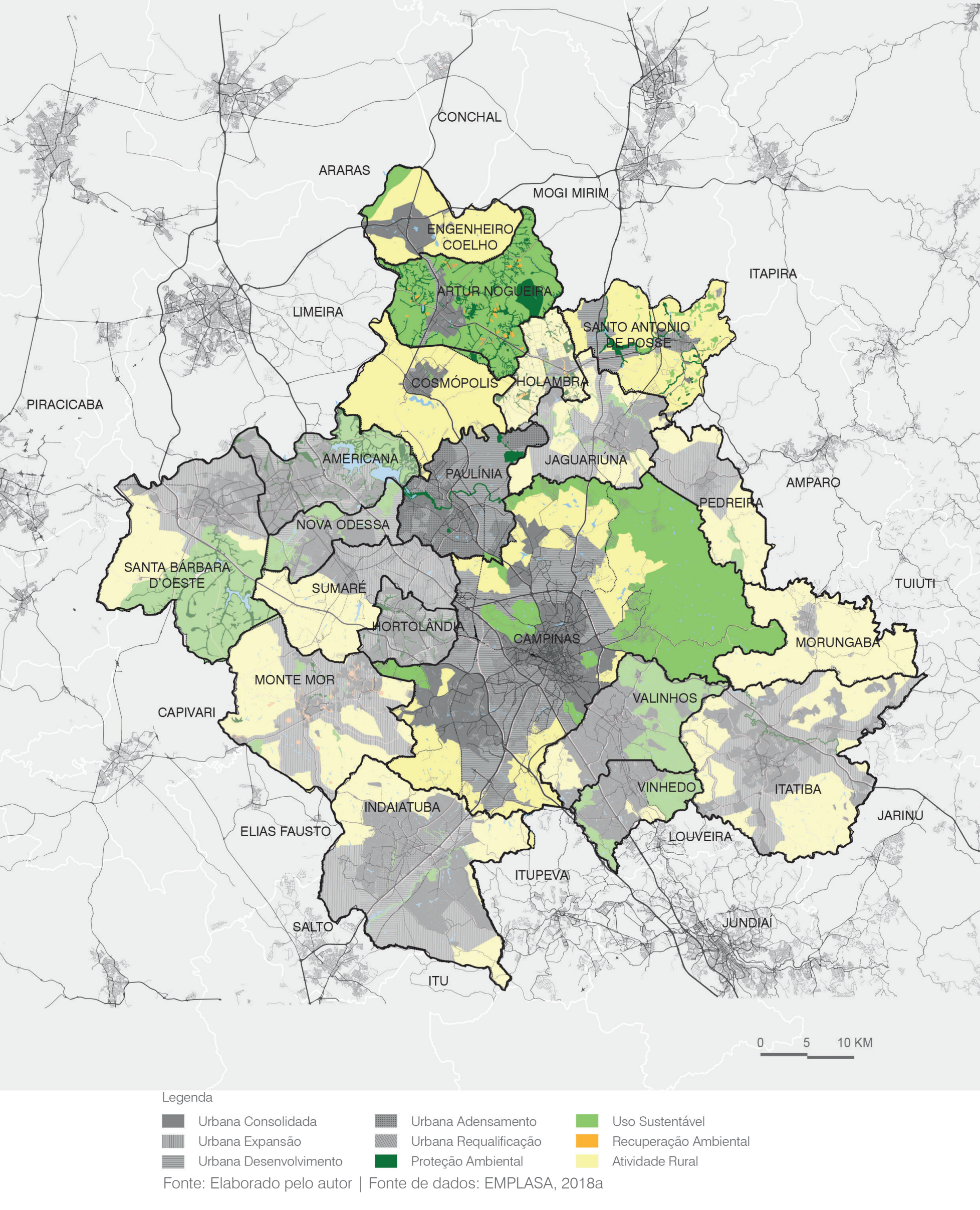


integrados fisicamente a eles), não são exclusivos à essa situação. Há a presença de comércios, serviços, áreas habitacionais e das próprias indústrias, nas áreas de dispersão urbana, principalmente nas áreas de acesso das rodovias.

A ocupação mais importante deste vetor, com maior destaque nas dinâmicas da metrópole, são os condomínios fechados de médio e alto poder aquisitivo. Segundo Nascimento (2013), esse tipo de ocupação do território vem se expandido de forma acelerada, principalmente na cidade de Paulínia, nos distritos de Betel e de Barão Geraldo. E o fato de Paulínia ser a cidade de maior riqueza neste vetor faz com que o município possa investir em fatores que contribuem para a atração destas camadas de renda e, consequentemente, deste tipo de ocupação, como infraestrutura Segundo o Centro de Estudos de Desenvolvimento Econômico (CEDE), em relatório para o PDUI da RMC (2018, p.55),

O municííio de Paulínia foi o que mais gastou com urbanismo, principalmente nos anos de 2005 e 2006 IPTU lm r lač̃a RCL Esse descompasso reflete o setor público pode incentivar indiretamente a tividade imobiliária através do investimento público somado a facilidades tributárias.

Em contrapartida, Cosmópolis, com arrecadação bem mais baixa que Paulínia, possui baixa capacidade de investimento em infraestrutura urbana, sobrecarregando alguns sistemas da região, como é o caso dos hospitais.

Ainda que esta dinâmica sobrecarregue alguns sistemas, atualmente ela demonstra como a utilização do espaço metropolitano pela população, de forma geral, está alinhado ao modo de vida metropolitano da RMC, que, se compreendido da forma como naturalmente ocorre, poderia ser melhor utilizado no fortalecimento da região.

\subsubsection{DINÂMICA POPULACIONAL NO VETOR 3}

Em relação às dinâmicas populacionais do Vetor 3, é importante destacar as altas taxas de crescimento populacional do município de Paulínia Segundo o Cunha e Jakob (2018b), "Paulínia já se encontrava entre os municípios que cresciam mais rapidamente entre 1991 e 2000, com uma taxa de $3,80 \%$ a.a. e apresentou a maior taxa anual de crescimento entre os anos de 2000 e 2010 (4,82\% a.a.)". Nesta época, o maior fluxo populacional era de população de baixa renda. No entanto, houve uma transformação na população migrante do município, a partir dos anos 2000. Algumas mudanças no orçamento municipal, a atuação do poder público na abertura de novos bairros e os grandes investimentos do capital imobiliário trouxeram para o município diversos lançamentos de loteamentos e condomínios fechados, atraindo uma população de alta renda

As taxas de crescimento de Paulínia, se comparadas às taxas de Campinas de apenas 1,09\% a.a., demonstram que o crescimento populacional da RMC e do Vetor 3 é cada vez mais periférico, tanto na relação entre as cidades menores e a cidade sede quanto na relação interna aos municípios, entre núcleo urbano consolidado e áreas de dispersão urbana.

Segundo o Cunha e Jakob (2018b), o cenário de estabilização do crescimento da população da cidade de Campinas também indicam que existem outros vetores de crescimento da ocupação do solo da região.

Por isso, é possível dizer que a ocupação do Vetor 3 e a formação das suas dinâmicas cotidianas tem cada vez maior relevância na compreensão da RMC. Os municípios de Cosmópolis, Artur Nogueira e Engenheiro Coelho, neste cenário, também apresentam taxas altas de crescimento populacional, dada a sua integração neste vetor pela SP-332.

A Figura 16 mostra que esta região é um vetor de crescimento demográfico, com destaque para Paulínia e Engenheiro Coelho. As outras primeiras posições em termos de crescimento populacional são representadas por 
(1)

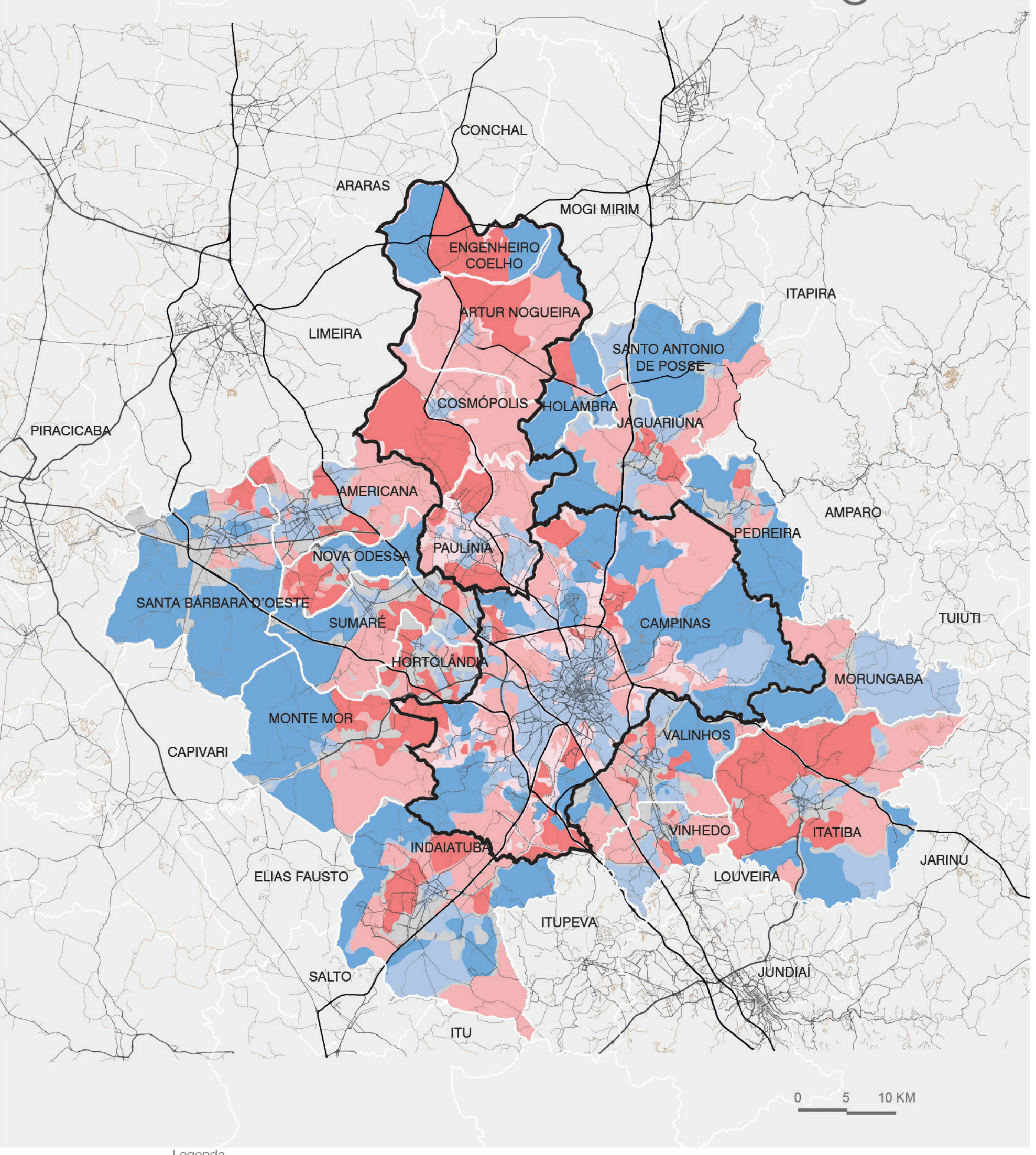

Legenda

Mais de 10

$0,5-1,82$
Até 0,5

$\square$ Municípios do vetor 3 e cidade sede

Fonte: Elaborado pelo autor | Fonte de dados: IBGE, Censo Demogrático, 2000 e 2010 (EMPLASA, 2018a) cidades que tem como características a implantação de condomínios e loteamentos para faixas de renda mais altas, como Indaiatuba e Vinhedo.

Outro fator importante na caracterização das dinâmicas populacionais da RMC é a migração intrametropolitana, ou seja, aquela que envolve trocas populacionais entre municípios da própria região. Em termos de volume, esta modalidade de migração envolveu mais de 64 mil pessoas no quinquênio 1995/2000 e cerca de 63 mil entre 2005 e 2010, segundo dados de Cunha e Jakob (2018b).

Importante ressaltar que houve aumento do fluxo migratório não apenas de mudança de residência entre municípios, mas também da dinâmica de utilização de serviços entre os municípios, de movimentos pendulares.

Dada a preponderância das trocas populacionais internas à metrópole, entre municípios, a estruturação do sistema viário tem real importância na realização dessas dinâmicas. Ou seja, essas relações só podem ocorrer pela manutenção das condições de mobilidade da região, que no Vetor 3 se estrutura pela Rodovia SP-332, por onde as migrações e a pendularidade da população, a ser abordada a seguir, podem ocorrer.

\subsubsection{MOBILIDADE NO VETOR 3}

A mobilidade na RMC e no Vetor 3, assim como citado anteriormente, tem como principal característica sua menor dependência em relação à cidade sede como único polo de atração, sendo intensa a relação entre os municípios menores, ou até mesmo com relação às cidades vizinhas, que estão fora da RMC. Assim como mostrado nas dinâmicas populacionais que estão presentes na região, a pendularidade se destaca como principal forma de deslocamento da população.

A pendularidade, aqui, deve ser entendida como a troca constante de cidades pelo cidadão metropolitano que se utiliza de todo o território para estabelecer seu espaço de vida. Neste caso, ele não se muda para uma outra cidade em função do seu trabalho, o que caracteriza seu movimento 
diário como pendular. Ao mesmo tempo, a não concentração dos postos de trabalho em Campinas ou a variedade de atividades espalhadas pelo território metropolitano faz com que as pessoas sejam menos dependentes de apenas um destino. Isso pode ser visualizado na Figura 17 e na Figura 18, ainda que o transporte coletivo possa parecer dissonante dessa característica.

Nas viagens de automóvel, é clara a condição da RMC de não ser dependente da cidade sede. A presença de vários núcleos de vetores de viagem mostra que as viagens intermunicipais são bastante importantes na dinâmica da região. Essa condição pode nos levar a compreender as rodovias não apenas como grandes eixos radiais (como se apresentam na sua forma), mas como elementos integrantes destes percursos que muitas vezes acontecem em trechos curtos ou transversalmente a elas.

A SP-332, por exemplo, pode ser vista como um grande eixo importante de conexão da cidade sede com todas as cidades que dela se aproximam Mas a SP-332 também tem características próprias em cada trecho, dada a diversidade da demanda dos fluxos que por ela passa. Como pode-se ver no mapa, a maior importância (quantitativa) da SP-332 para Campinas é o acesso ao polo tecnológico que compreende as Universidades (UNICAMP e PUCC) e diversas empresas de tecnologia e também aos condomínios fechados da região. Assim também ocorre com Paulínia, com forte conexão, pela SP-332 com o distrito de Betel - condomínios - e o polo tecnológico. Para Cosmópolis, a maior importância da SP-332 é a conexão com Paulínia

No entanto, o padrão se altera quando se trata do transporte coletivo, sendo mais evidente o sistema radial de deslocamento, com maior dependência da cidade sede. Essa condição é explicada por Cunha e Jakob (2018a, p.19)

A cidade de Campinas, como sede da RMC, é tanto destino como origem das principais interligações de linhas de ônibus, isso porque o modelo de transportes na região é de caráter "centralizador", ou seja, baseado em terminais intrametropolitanos que atuam como pontos de conexões e redistribuição das linhas de ônibus. Assim, por exemplo, o passageiro que deseja sair de Hortolândia para acessar a cidade de Paulííia, necessita encaminhar-se antes para o centro de Campinas, em um terminal intrametropolitano, para depois pegar uma linha com destino à Paulínia o mesmo acontece com o distrito de Barão Geraldo, em Campinas, que mesmo estando muito próximo Hortolândia, não possui ligação direta com este município, forçando os que trabalham nessa área a deslocamentos de onga duração.

Diferente do restante da RMC, nas viagens por transporte coletivo, os fluxos nas cidades do Vetor 3 se comportam de forma similar às viagens por automóvel, eixos menores de deslocamento. É possível dizer, assim, que o Vetor 3 é o que tem menor dependência no total de viagens com destino a Campinas. As cidades menores têm seu maior fluxo de viagens para as cidades vizinhas, atrás apenas das viagens dentro dos próprios municípios. E as viagens não se restringem aos municípios do próprio vetor a que pertence.

No Vetor 3, por exemplo, Artur Nogueira apresenta maior número de viagens com destino a Holambra, cidade vizinha pertencente a outro vetor por meio de uma rodovia do sistema complementar. Essa lógica evidencia a complexidade do sistema viário da RMC e dos espaços de vida da população que ela habita. Além das rodovias que estruturam a região, existem estradas e vias que não estão inseridas nos núcleos urbanos que fazem conexões entre municípios e áreas dispersas no território e que permitem a organização do modo de vida metropolitano, que ocorre de forma descentralizada, dispersa no território.

Isso reforça a escolha do Vetor 3 como objeto de estudo desta pesquisa, já que permite a compreensão do papel das rodovias e estradas no cenário metropolitano, em que há forte presença de um modo de vida metropolitano. O fato de não ser apenas um grande eixo de transporte para acesso à cidade sede, mas um elemento importante para diversos tipos de conexão, permite que sejam reconhecidos usos e atividades que se aproximam das dinâmicas urbanas. 
CAPÍTULO 3

LEITURAS E CARACTERIZAÇÃO DO VETOR 3 ESCALA DO TECIDO URBANO 


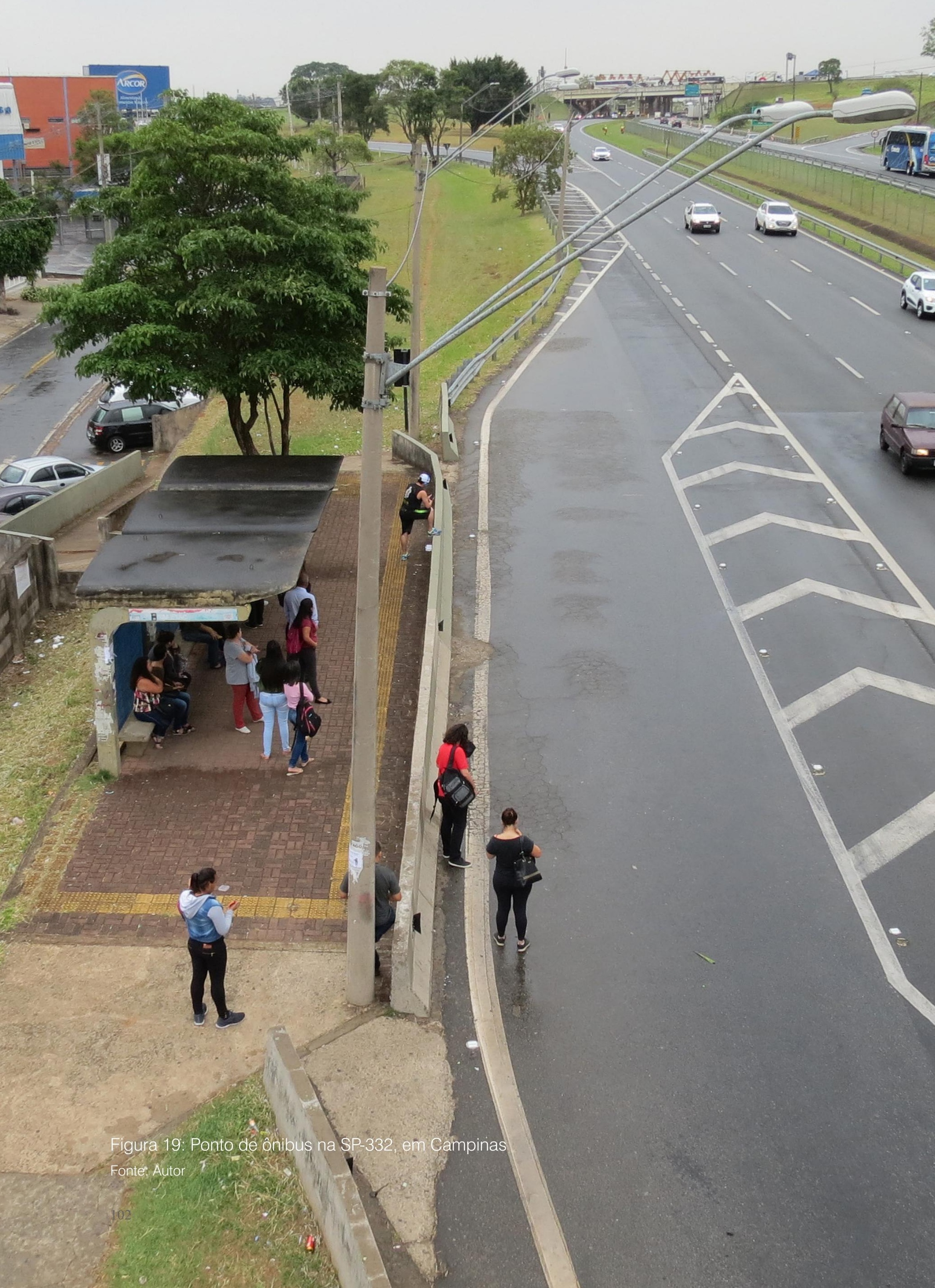

\section{LEITURAS E CARACTERIZAÇÃO DO VETOR 3 - ESCALA DO TECIDO URBANO}

Diante da apresentação dos dados gerais da RMC e da caracterização das dinâmicas em escala metropolitana do Vetor 3, estruturado pela Rodovia SP-332, será abordada aqui a caracterização do Vetor 3 a partir das escalas humana e do tecido urbano. Ou seja, serão mostrados os elementos que compõem o eixo de estudo, considerando suas formas e relações, na construção do cenário urbano/metropolitano deste trecho da $\mathrm{RMC}$

Visto que o interesse da pesquisa se encontra na qualificação do modo de vida metropolitano e na busca dos espaços da vida pública com foco na mobilidade, foi necessário encontrar parâmetros que permitissem organizar o olhar sobre o território. Desta forma, optou-se por desenvolver esta caracterização sobre a classificação do sistema viário do Vetor 3, baseado em definições do Sistema Viário de Interesse Metropolitano (SIVIM), um programa de planos e ações da Empresa Metropolitana de Transportes Urbanos (EMTU) e da Secretaria dos Transportes Metropolitanos do Estado de São Paulo, conforme será mostrado a seguir.

\subsection{A CLASSIFICAÇÃO DAS RODOVIAS}

Para que fosse escolhida a forma mais apropriada de classificação das rodovias para a caracterização das formas de ocupação e das dinâmicas do Vetor 3, foi necessário compreender as possibilidades de classificação das vias de um sistema viário, que se baseiam em duas formas principais pelas qualidades das próprias vias ou pela sua função no sistema viário.

O primeiro modo encontrado, portanto, se concentra na definição dos níveis de serviço das vias, que significa identificar a qualidade física das 
vias (seja para veículos motorizados, seja para bicicletas e pedestres). De acordo com Setti (2009), nível de serviço é uma forma de classificar qualitativamente a via/viagem, baseado em fluxo e velocidade. Este conceito, de qualidade de serviço, foi inicialmente proposto nos EUA e é, atualmente, adotado no restante do mundo, tornando-se uma medida fundamental para a avaliação do desempenho de trechos de rodovias sob o ponto de vista do fluxo de tráfego.

Ométodo principal deste tipo de classificaçãoé o Highway Capacity Manual (HCM 2000), que mede a qualidade de serviço das vias, (YUASSA, 2008) em conjunto com outros métodos que o alimentam ou são influenciados por ele. O HCM 2000 tem como objetivo determinar o nível de serviço de vias urbanas, considerando, segundo Yuassa (2008, p.8) "medidas de desempenho de um segmento de rua, com base na velocidade média de viagem, no número de semáforos por quilômetro e no tempo de ciclo dos semáforos". Esse tipo de classificação pode ser considerado uma medida indireta de satisfação do usuário, uma vez que as formas de avaliação qualitativa, com foco no ponto de vista do usuário da via, ainda não foram completamente testadas.

Para a avaliação do nível de serviço sob o olhar dos pedestres, Yuassa (2008) faz um comparativo entre os índices utilizados pelo HCM 2000 e outros cinco métodos principais, todos elaborados no exterior. Analisando suas considerações, é possível dizer que o método de Fruin e o HCM estão voltados à condição física da própria via, específica para os pedestres. Fruin, por exemplo, considera a anatomia humana e a distância confortáve entre corpos como parâmetros de classificação. Já nos métodos de Sarkar e Dixon, os parâmetros de avaliação são voltados às questões qualitativas da via, como segurança, conveniência, coerência do sistema

1 De acordo com o Manual, "The Transportation Research Board's (TRB's) Highway Capacity Manual (HCM) provides a collection of state-of-the-art techniques for estimating the capacity and determining the level of service for transportation facilities, including intersections and roadways as well as facilities for transit, bicycles, and pedestrians. For more than 50 years, the HCM has fulfilled this goal, earning a unique place in the esteem of the transportation community". e atratividade, por exemplo. Khisty e Ferreira e Sanches, ampliam os parâmetros qualitativos para incluir variáveis subjetivas, como atratividade visual e conforto

Ainda que estes métodos para os pedestres sejam qualitativos, ainda são focados na análise de trechos de via e na qualificação das condições da própria via, excluindo da avaliação as questões urbanas, de inserção da via no contexto urbano, além de não considerar as relações humanas que ocorrem nestes espaços.

Nesta pesquisa, o que se busca é compreender de que formas estas vias servem de campo de realização da vida pública, não apenas qualificá-la como mais ou menos segura. Além disso, é importante compreender sua função dentro do sistema de vias e de espaços livres, no modo de vida metropolitano, observando as formas como as vias são fisicamente em conjunto das formas como são apropriadas. Em resumo, a classificação por nível de serviço considera apenas os fatores de passagem, não a permanência.

Outro fator importante destes métodos é que, principalmente no caso dos pedestres, tratam de vias inseridas no espaço urbano consolidado, não considerando, por exemplo, as rodovias e estradas, visto que não são lugares próprios dos pedestres.

O segundo modo de classificação de vias é baseado na função da via no sistema viário e a principal definição é dada pelo Código de Trânsito Brasileiro (CTB), que apresenta classificações para o sistema viário urbano geralmente utilizadas pelos municípios no seu planejamento viário. De acordo com o CTB, as vias podem ser classificadas como: rurais, que são as estradas e rodovias; e urbanas, que são as ruas, avenidas, vielas, ou caminhos e similares abertos à circulação pública, localizados nas áreas urbanas e caracterizados, principalmente, por possuírem imóveis edificados ao longo de sua extensão.

A partir dessa definição, é feita a classificação das vias urbanas de acordo com sua função no sistema viário. As categorias são as vias de trânsito 
rápido, caracterizadas por possuírem acessos especiais e trânsito livre sem interseções em nível, incluindo ausência de travessia de pedestres e sem acessibilidade direta aos lotes lindeiros; as vias arteriais, que possuem interseção em nível, com acessibilidade aos lotes lindeiros e possui integração direta com as vias secundárias e locais, possibilitando conexões entre regiões da cidade; as vias coletoras, destinadas a coletar o trânsito das vias de trânsito rápido e das arteriais, possibilitando deslocamento dentro das regiões da cidade; e as vias locais, que permitem interseções em nível e que são destinas ao trânsito e acesso à áreas locais ou restritas.

O CTB também define a velocidade das vias, seguindo as classificações citadas anteriormente. Para as vias urbanas, a hierarquia das vias define a gradação dos limites de velocidade, sendo $80 \mathrm{Km} / \mathrm{h}$, nas vias de trânsito rápido; $60 \mathrm{Km} / \mathrm{h}$, nas vias arteriais; $40 \mathrm{Km} / \mathrm{h}$, nas vias coletoras; $30 \mathrm{Km} / \mathrm{h}$, nas vias locais. Já nas vias rurais, a velocidade sofre variações de acordo com a forma da via e de acordo com o meio de transporte que circula por ela, sendo nas rodovias de pista dupla: $110 \mathrm{Km} / \mathrm{h}$ para automóveis, camionetas e motocicletas e $90 \mathrm{Km} / \mathrm{h}$ para os demais veículos; nas rodovias de pista simples: $100 \mathrm{Km} / \mathrm{h}$ para automóveis, camionetas e motocicletas e $90 \mathrm{Km} / \mathrm{h}$ para os demais veículos e nas estradas, $60 \mathrm{Km} / \mathrm{h}$.

Ainda que essas classificações considerem a função da via no sistema, não consideram as formas de apropriação pela população, tendo como foco os veículos e não os pedestres ou os demais modais. O estabelecimento das velocidades demonstra, ainda, que a inserção rural ou urbana é um fator importante na organização das vias. No entanto, não se considera a inserção das vias no espaço metropolitano, nem pondera questões qualitativas da própria via ou dos seus usuários.

Diante dessas formas existentes de classificação de vias, que não colaboram diretamente para as buscas desta pesquisa, apesar de poderem ser aplicadas ao sistema viário do Vetor 3 da RMC - as definições do CTB por exemplo, são usados nos planos diretores de alguns municípios optou-se por utilizar as categorias de vias definidas pelo SIVIM, como base para esta pesquisa, uma vez que trata do sistema viário metropolitano, não se restringindo ao espaço intraurbano.

O SIVIM é um programa cujo conceito foi criado durante a elaboração de estudos de acessibilidade para a Região Metropolitana de São Paulo (RMSP), através de programa denominado Caminhos Metropolitanos, realizado pela Secretaria dos Transportes Metropolitanos (STM), em 1997. Esse estudo tinha como objetivo estabelecer referências na estrutura do sistema viário básico existente, que apresentassem caráter de interesse metropolitano, o que permitiria uma visão integrada do sistema viário, a sua classificação e o seu mapeamento (EMTU, 2006)

Dessa forma, o SIVIM considera todo o sistema viário "reconhecido pelos poderes públicos estadual e municipais, caracterizado pelas vias principais que estabelecem relações de acessibilidade entre municípios, seus polos geradores de tráfego e núcleos expressivos, dentro das três regiões metropolitanas do Estado de São Paulo - São Paulo, Campinas e Baixada Santista" (EMTU, 2006).

As vias que são classificadas são, portanto, as rodovias estaduais e federais, nos trechos que cumprem a função de ligação ou de suporte intermunicipal; os corredores intermunicipais ou municipais de transporte público; as vias municipais, quando se constituem em elos de ligação intermunicipal; e as vias municipais principais, que permitem o acesso a equipamentos de interesse das regiões metropolitanas. Para esta pesquisa, essa definição se mostra útil por considerar tanto as vias localizadas nos núcleos urbanos consolidados quanto as vias em áreas de ocupação urbana dispersa e nas áreas rurais.

A classificação que se estabelece, então, é a seguinte, segundo o SIVIM: VIAS MACRO METROPOLITANAS, que compreendem as vias que configuram a interface das ligações externas da metrópole com a articulação principal do viário metropolitano, formado pelas rodovias, vias marginais e vias estruturais anelares. 
VIAS METROPOLITANAS, que compreendem a malha formada pelas ligações intrametropolitanas, estabelecendo relações de acessibilidade entre áreas centrais dos municípios, polos e núcleos de assentamento urbano dentro das regiões metropolitanas. É formada pela rede de antigos caminhos, estradas estaduais ou municipais e por intervenções viárias projetadas para a conexão de polos e subcentros que se consolidaram e se transformaram ao longo do tempo em ligações preferenciais:

VIAS METROPOLITANAS SECUNDÁRIAS, que consistem na rede viária formada pelas vias municipais utilizadas nos serviços de transportes metropolitanos de passageiros e que permitem o acesso a equipamentos de porte relacionados ao sistema de transporte e de interesse para as regiões metropolitanas.

Ainda que essa classificação seja importante para estabelecer direções, é insuficiente na caracterização de fato da via, já que, assim como as classificações do CTB, não se atentam às questões qualitativas do sistema viário, nem da sua relação com os pedestres.

Outra questão colocada pelo SIVIM, importante de se ressaltar, é que ele apresenta uma diretriz básica, na qual relata que o "sistema viário macrometropolitano deve ser preservado de forma a não assumir também o tráfego local urbano uma vez que as características de cada tipo de tráfego impedem o bom desempenho de ambos quando são forçados a compartilhar uma mesma pista" (EMTU, 2006).

Essa condição, para a RMC e no Vetor 3, no entanto, não se concretiza, visto que é normal que as vias integrantes do SIVIM sejam utilizadas por tráfegos diversos, misturando tipos de veículos diferentes e viagens com interesses muitas vezes conflituosos.

No Vetor 3 da RMC, o sistema de vias proposto pelo SIVIM se configura conforme demonstrado na Figura 20. Estruturado pela SP-332, apresentada no Capítulo 2, o SIVIM ainda compreende outras vias importantes para a dinâmica interna do vetor e na sua relação com o restante da RMC.

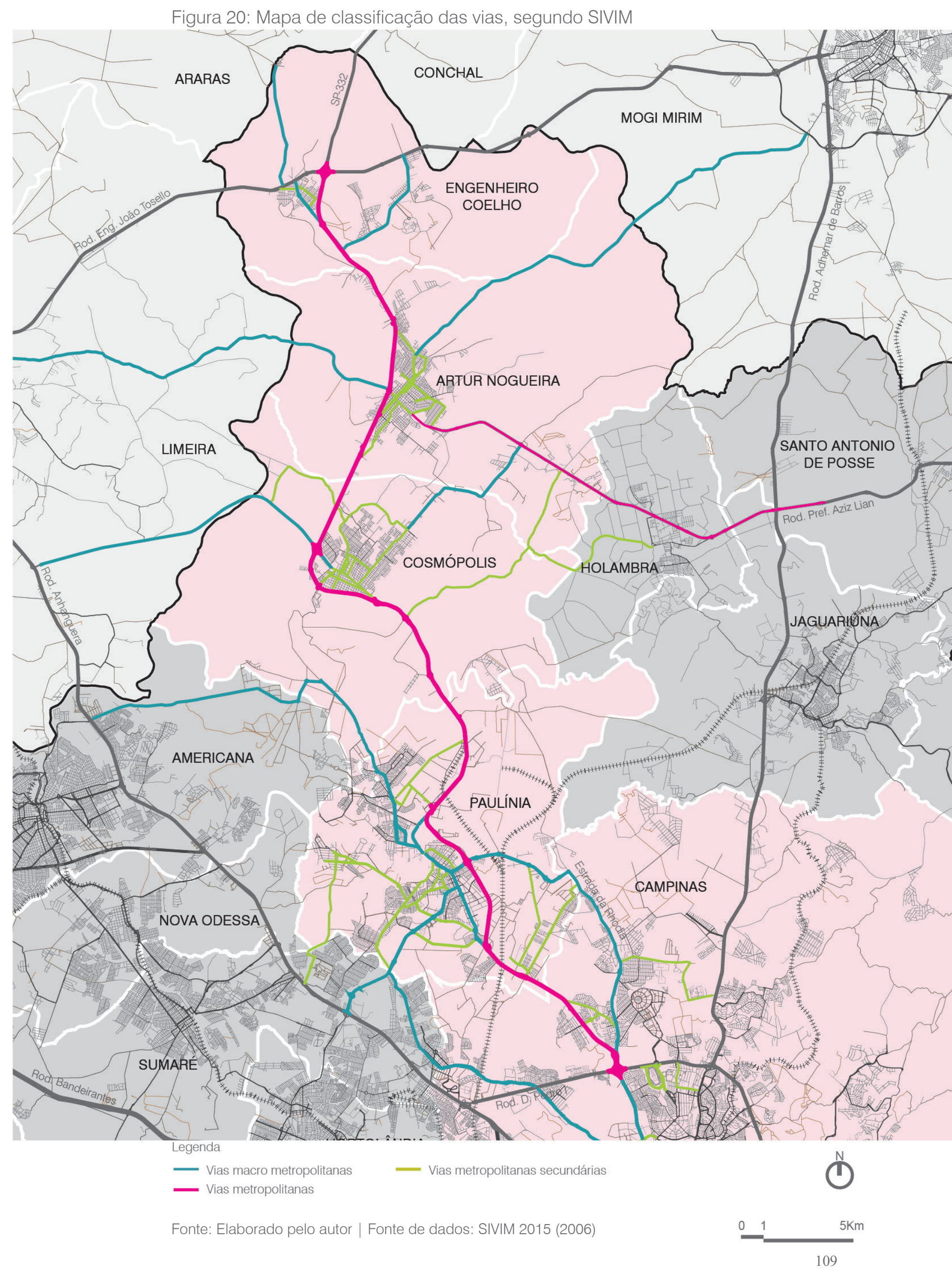


Na categoria de Macro Metropolitana, além da SP-332, está a Rodovia Aziz Lian, que liga Artur Nogueira à Holambra, fazendo a integração do Vetor 3 com o eixo nordeste, estruturado pela Rodovia Adhemar de Barros.

As Vias Metropolitanas estão presentes em maior quantidade, com a função de conectar as cidades do Vetor 3 com as cidades vizinhas, sejam elas pertencentes à RMC ou não. Vale destacar:

- A Estrada da Rhodia, que liga Paulínia ao distrito de Barão Geraldo, passando por Betel, como importante eixo de localização dos condomínios fechados de alto padrão, tanto de Paulínia como de Campinas e pela conexão com as indústrias de alta tecnologia;

- A Rodovia Americana-Paulínia, como principal eixo de crescimento da cidade de Paulínia e ligação com a Rodovia Anhanguera;

- A Avenida Pref. José Lozano Araújo em continuidade da Rodovia Adauto Campo Dall'Orto, que liga Paulínia à Sumaré, importante eixo de estruturação de Paulínia, com a implantação de equipamentos de lazer e cultura de grande porte, como o sambódromo e o teatro, além do polo cinematográfico;

- A Estrada Vicinal Pref. Orlando Kiosia, de conexão entre Cosmópolis e a Rodovia Aziz Lian, que dá acesso à Holambra, e é um dos eixos de crescimento da cidade de Cosmópolis e de implantação de condomínios fechados, além de possibilitar acesso à produção agrícola;

- A Rodovia José Santa Rosa, de ligação entre Artur Nogueira e Limeira pela interação entre as cidades, principalmente pela atração dos estudantes de Artur Nogueira pelas universidades de Limeira;

- A Estrada Municipal Pastor Walter Boger, de ligação entre a SP-332 e a Rodovia Engenheiro João Tosello, em Engenheiro Coelho, que se tornou vetor de implantação de condomínios fechados de alto padrão.

- A SP-133 que liga Cosmópolis à Paulínia, fazendo a conexão entre a SP-332 e a Rodovia Anhanguera
Já as vias Metropolitanas Secundárias podem ser resumidas às principais avenidas dos núcleos urbanos consolidados, podendo ser descritos pela concentração de comércios e serviços nas áreas lindeiras. Além disso, podem ser destacadas as vias fora dos núcleos urbanos, em áreas de indução de ocupação, como pode ser observado em Cosmópolis, com a ocupação por chácaras e sítios pequenos, ou em Paulínia, como ocorre com Betel, com a ocupação recente por condomínios, mas ainda com muitos vazios e resquícios de produção agrícola.

Dentro do contexto do Vetor 3, portanto, é interessante observar que a classificação proposta pelo SIVIM não faz distinção da ocupação das áreas lindeiras para a indicar a função das vias. Neste sentido, a mesma classificação de via pode ocorrer em áreas urbanas e rurais, ou nas áreas intersticiais de ocupação dispersa, bastante característico da região, como já abordado nos capítulos anteriores. Por essa razão, essa classificação foi bastante útil como guia da caracterização do Vetor 3, na busca pela vida pública destes espaços metropolitanos.

\subsection{A PESQUISA DE CAMPO}

Apesar de já ter feito parte das relações e dinâmicas na maior parte dos espaços da mobilidade do Vetor 3, foi necessário realizar idas a campo, para observação e coleta de dados, através de levantamentos fotográficos e entrevistas semiestruturadas, a fim de atualizar as percepções e diversificar os pontos de vista sobre o tema

As visitas ocorreram em três dias, sendo uma no sábado, uma no domingo e uma na segunda-feira. Durante esses dias, foram percorridas e fotografadas todas as vias classificadas pelo SIVIM, conforme mapa apresentado anteriormente. No final de semana foi feito o reconhecimento das vias, aproveitando o menor fluxo, o que permitiu observar suas condições físicas e a ocupação lindeira, além da observação das dinâmicas 
com maior tendência ao lazer da população que ali habita. Já na segundafeira, foi realizado o levantamento das dinâmicas cotidianas das vias, em dia de grande fluxo e maior movimento de pessoas por todo o território.

Foram utilizadas três formas de deslocamento: por automóvel, para percorrer todas as vias de forma independente do transporte coletivo e com maior capilaridade do território; por meio de ônibus metropolitano, para realização de entrevistas com os passageiros e para o reconhecimento dos trajetos rígidos dos movimentos de grande parcela da população, além da observação dos lugares de transição de modal, na rodovia, como os pontos de parada; e a pé, nos trechos de travessias e passarelas, para entrevistas e observação das dinâmicas transversais à via.

No levantamento fotográfico foram considerados os seguintes aspectos: os tipos de transporte que trafegam pela região; as formas de ocupação do território (atividades principais como comércio, indústria, residências); as formas de transposição das vias (passarelas, passagens); e as situações em que a vida pública acontecia, nos espaços metropolitanos.

Para a entrevista, foram escolhidos os lugares que seriam possíveis encontrar as pessoas durante seus trajetos, como nos ônibus, nos pontos de ônibus, nas passarelas ou nas marginais da rodovia. As questões realizadas eram básicas, com a finalidade de obter breve qualificação da identidade das pessoas, dos seus trajetos cotidianos e suas relações com o Vetor 3 da RMC. Das pessoas entrevistadas, em um total de 34 indivíduos, apenas 10\% das pessoas não moravam na região do Vetor 3 e aproximadamente $40 \%$ das pessoas eram migrantes, vindas de cidades de fora da RMC, incluindo pessoas de fora do Estado de São Paulo, como Minas Gerias e Rio de Janeiro.

Todas as pessoas entrevistadas têm mais de 18 anos, sendo observada a presença de crianças nas passarelas próximas aos núcleos urbanos. Apesar de terem sido entrevistados indivíduos de várias faixas etárias entre 18 e 70 anos, houve a concentração de pessoas de até 25 anos. Já em relação ao gênero, observou-se uma maior quantidade de mulheres no sistema de ônibus metropolitano, sendo 55\% mulheres, 45\% homens.

Em relação à profissão ou ocupação diária, a maioria dos entrevistados exerce profissões de baixa qualificação, como operador de telemarketing, faxineira, jardineiro, eletricista e auxiliar de produção. Essa condição foi encontrada tanto nas entrevistas realizadas no ônibus metropolitano que tem as indústrias como principal atrativo das viagens, quanto nas passarelas e vias marginais. Dos entrevistados, $78 \%$ trabalhavam e apenas $32 \%$ eram estudantes, sendo que apenas um deles era do ensino médio e um deles estudava em universidade pública. Todos os outros faziam cursos em universidades particulares, em Paulínia, Americana ou Limeira.

Sobre os tempos de deslocamento nos trajetos diários, a média se concentrou entre 30 minutos e uma hora de viagem. É interessante destacar, também, que 30\% das pessoas não faziam o trajeto que estavam fazendo naquele dia diariamente, o que indica a variação de trajetos na dinâmica metropolitana, assim como indicado na caracterização das dinâmicas dos movimentos pendulares do Vetor 3

Quando perguntados sobre as cidades que frequentam na região, os entrevistados citaram, na maior parte das vezes, cidades do próprio Vetor 3, confirmando a concentração das dinâmicas. São exceções: Americana que aparece como destaque de atração por motivos variados, fora do Vetor 3, mas ainda dentro da RMC; Limeira, que não pertence à RMC citada principalmente pelos entrevistados das passarelas próximas às cidades menores, como Artur Nogueira e Engenheiro Coelho; Holambra, como local de turismo; e Indaiatuba, por questões familiares.

É possível afirmar, ainda, pelas entrevistas, que as pessoas se utilizam mais das cidades do entorno mais próximo. Sua ida até Campinas ocorre apenas em momentos específicos, como uma viagem mais longa, pela questão do terminal rodoviário ou do aeroporto, ou, ainda, por motivo de compras ou serviços especializados, que se concentram na cidade sede. 


\subsection{CARACTERIZAÇÃO DO VETOR 3}

A partir das questões básicas levantadas nas entrevistas, foram coletadas informações que colaboraram com a caracterização que será apresentada a seguir, divididas em três grupos principais: os tipos de transporte; as formas de ocupação; e os elementos de integração e transposição dos sistemas de transporte.

\subsubsection{TIPOS DE TRANSPORTE}

Os primeiros elementos observados durante o levantamento em campo foram os meios de transporte, sejam motorizados ou ativos. Através deles é que os deslocamentos da região acontecem e sua diversidade ilustra o cotidiano do modo de vida metropolitano.

Durante as entrevistas realizadas pelos trajetos da área em estudo, os meios de transporte mais citados foram o ônibus, o "a pé" e o automóvel. O ônibus foi o mais citado, visto que metade das entrevistas foram realizadas no interior de um ônibus intermunicipal e a outra metade na região das passarelas ou em áreas próximas aos pontos de ônibus, que são áreas com maior concentração de pessoas. Ainda assim, nesta situação favorável ao transporte coletivo, o automóvel aparece em terceiro lugar, perdendo apenas para o "a pé". Em seguida, são citadas a bicicleta e os transportes fretados.

Ainda que não tenham sido entrevistadas pessoas usuárias exclusivas de automóveis, visto que o acesso a elas, no meio do seu deslocamento, seria inviável, uma vez que estão em grande velocidade no espaço público, é importante ressaltar a observação da presença ininterrupta de automóveis na paisagem, o que confirma os dados fornecidos pela Pesquisa OrigemDestino de 2011, da RMC.

Outra inversão que deve ser observada é a relação entre ônibus e "a pé". Ainda que algumas pessoas não tenham considerado o caminhar como um 
modal a se considerar nas suas viagens diárias, a descrição dos trajetos sempre envolvia algum trecho de caminhada, para acessar o ponto de ônibus ou o local de embarque do fretado. Mesmo que o trajeto casa-ponto de ônibus no início do trajeto seja feito de automóvel, carona ou bicicleta, o ponto de chegada do ônibus nunca era próximo do destino final, de fato. A caminhada era sempre necessária, em algum trecho do relato. A ocupação dispersa do território faz com que seja necessário utilizar-se de meios de transporte que permitam maior capilaridade, características do caminhar, da bicicleta e do automóvel.

Também é importante ressaltar que foi citado, nas entrevistas, o uso de Uber como meio de transporte. No entanto, o uso desses aplicativos não é comum nessas cidades, visto que seu espaço intraurbano é pequeno, com outras formas de acesso e transporte mais tradicionais.

A seguir, serão apresentadas impressões e breves dados que caracterizam cada meio de transporte presente na RMC, identificados e fotografados durante a pesquisa em campo. A apresentação é realizada pela pirâmide inversa do transporte, considerando as prioridades de circulação nas vias. Assim, inicia-se a caracterização com os transportes ativos, incluindo os pedestres e as bicicletas, seguidos pelo transporte público coletivo o transporte coletivo particular, os transportes de carga (rodoviário e ferroviário) e o transporte individual motorizado, incluindo automóveis, motocicletas e caronas

\section{TRANSPORTES ATIVOS}

\section{A pé}

De acordo com os dados da Pesquisa Origem-Destino de 2011 (EMPLASA 2012), da RMC, uma parcela significativa das viagens da região se faz a pé sendo $25,1 \%$, ficando atrás apenas do automóvel, com 38,5\% do total de viagens. Apesar disso, nas referências consultadas, o tema do caminhar pela região metropolitana, nos espaços de importância metropolitana não são tratados de forma direta, sendo considerados como mais um dos elementos dos movimentos pendulares ou restritos aos espaços intraurbanos. Nos planos e projetos para a RMC, esse tema geralmente é reduzido às questões de segurança viária, como por exemplo no diagnóstico elaborado pela EMPLASA (2018b), para o PDUI da RMC.

De acordo com a EMPLASA (2018b, p.68), "quando o viário macrometropolitano é inserido no tecido urbano, fragmenta o território, seccionando bairros, e chegando por vezes a interferir nas relações sociais das populações afetadas. Em muitos casos, as pessoas são obrigadas a atravessar a rodovia em suas atividades rotineiras". No entanto, a resposta imediata dada por esse plano se constitui na indicação de instalação de equipamentos de travessia, como passarelas de pedestres ou dispositivos para automóveis. Também inclui a necessidade de investir em treinamento, programas, cursos e campanhas para educar a população usuária e os agentes de trânsito.

Ou seja, as iniciativas a serem tomadas para melhoria da condição do pedestre é educá-lo no convívio com o sistema rodoviário, que possui maior importância na configuração do território. Desta forma, o lugar do pedestre acaba por se restringir a pontos específicos do território.

Nesta pesquisa, no entanto, foram identificados pedestres ocupando todo o território, em áreas imprevisíveis, com ausência de infraestrutura. A ocupação fragmentada do território é a principal causa dessa condição, uma vez que desperta demandas de acesso à diversas áreas em distâncias 
De forma mais comum, os pedestres estão presentes no espaço intraurbano, dividindo espaço na rua com todos os outros modais, com maior liberdade na circulação, como mostrado na Figura 21. Ainda que seu lugar seja restrito às calçadas, utiliza do leito carroçável como espaço para caminhar. Nas cidades menores, principalmente, que possuem menor fluxo de veículos motorizados, o uso compartilhado das vias, além da travessia em locais não destinados ao pedestre são mais frequentes. Ainda que essa condição seja cotidiana, é possível dizer que a construção do espaço urbano não a leva em consideração, restringindo-se a utilizar padrões viários tradicionais, de segregação dos espaços.

Na cidade de Engenheiro Coelho, por exemplo, mostrada na Figura 22 é possível observar um cenário de excesso de infraestrutura, com ciclovia arborização cênica, sinalização, iluminação, pavimentação das vias, guias e sarjetas em bom estado de conservação. No entanto, as calçadas são inexistentes, obrigando o pedestre a utilizar o leito carroçável como lugar de circulação, demonstrando que sua presença não é considerada ou não é desejada.

No caso das vias metropolitanas, nas quais geralmente estão localizados os condomínios ou loteamentos residenciais fechados e que se encontram fora do espaço intraurbano, é possível observar que, ainda que exista infraestrutura para os pedestres, o espaço reservado possui dimensões mínimas e é precário, como mostra a Figura 23. Neste condomínio em Engenheiro Coelho, além da calçada ser pequena em relação ao espaço dos outros modais, ela está disponível apenas em um dos lados da via. Além disso, a falta de arborização no local, com grandes áreas livres parece contraditória, obrigando os pedestres a caminharem por calçada ladeada por muro alto e sob o sol. Vale ressaltar, ainda, que a calçada se limita à frente do condomínio e é inexistente a partir do final do muro.

Figura 21: Pedestre caminha pela rua, dividindo espaço com outros modais

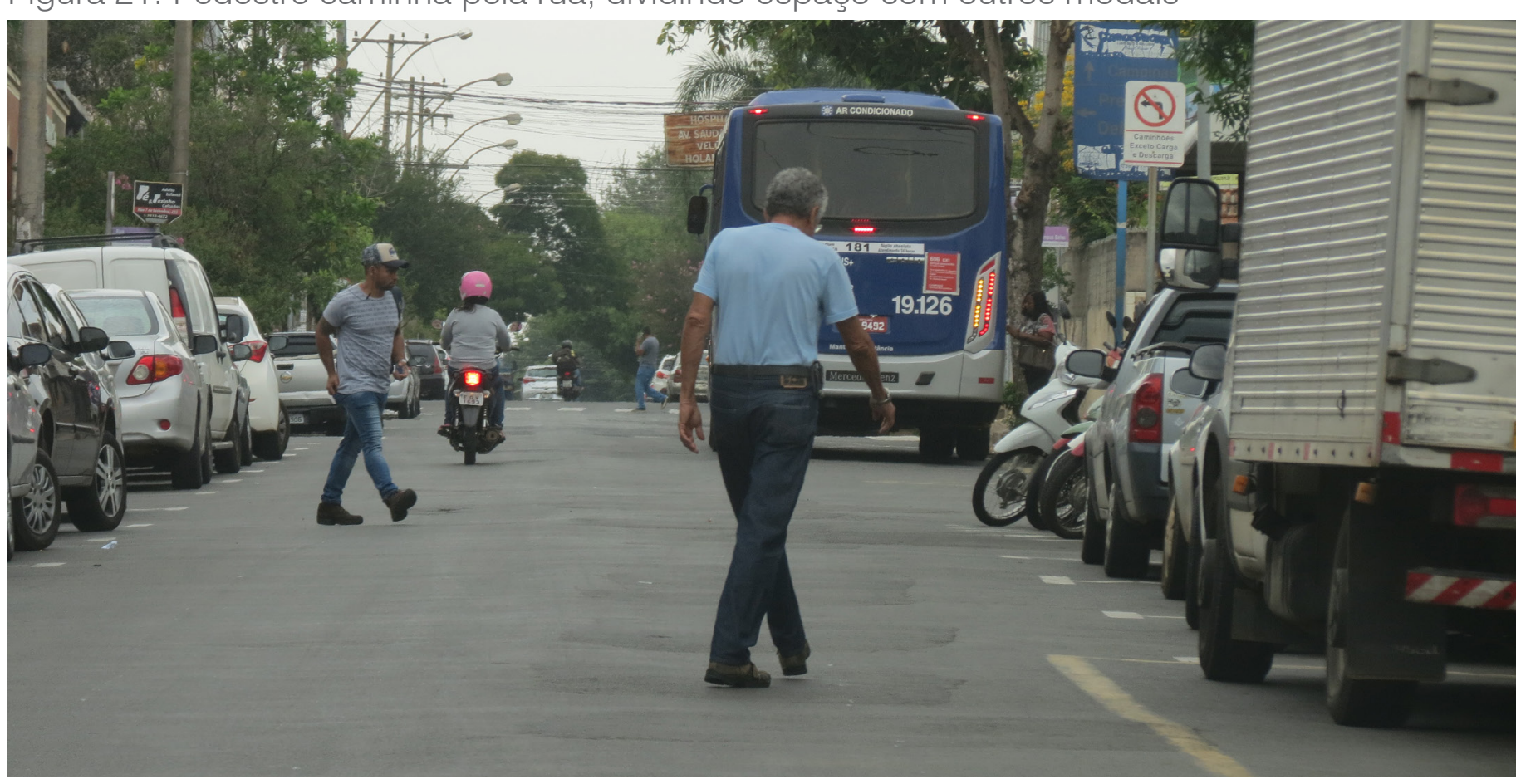

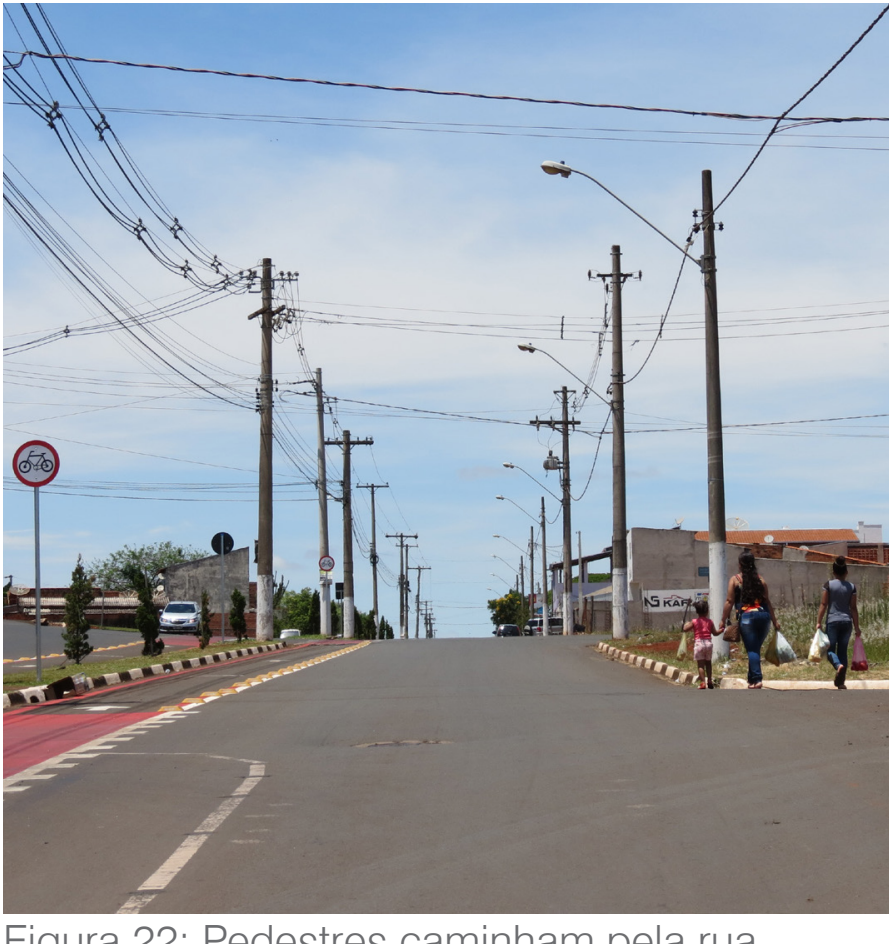

Figura 22: Pedestres caminham pela rua

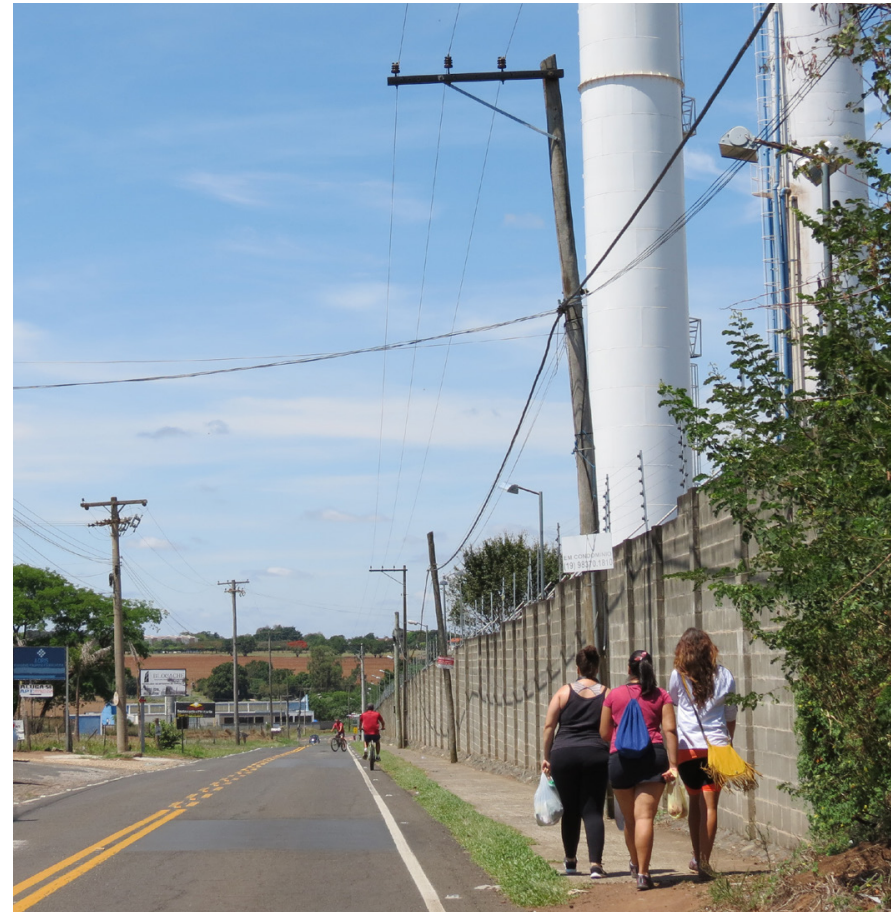

Figura 23: Passeio próximo ao condomínio 
Em outras situações próximas aos condomínios, como mostra a Figura 24, o cenário para os pedestres é ainda menos amigável. O viário deste trecho no distrito de Betel, é confinado pelos muros dos condomínios e possui atenção total ao automóvel, demonstrada pela falta de pavimentação das calçadas, substituída pela grama. Essa forma de tratamento dos passeios indica que os pedestres não são bem vindos naqueles locais.

Já nas vias macrometropolitanas, o espaço encontrado para o pedestre é o acostamento da rodovia, sem nenhum tipo de proteção em relação ao trânsito de alta velocidade. Na Figura 25, é possível observar pessoas caminhando pela RodoviaSP-332, ainda que não seja possível compreender sua origem nem seu destino, já que não existe ocupação lindeira a via. Essa caminhada, portanto, pode ter sido feita em distâncias maiores que as observadas quando se trata do pedestre no meio urbano. Neste caso, a falta de condições ou de qualidade da via não são impeditivas na circulação de pedestres por estes locais

Mas não apenas nas rodovias ou nos núcleos urbanos os pedestres circulam. Nas estradas também é comum observar pessoas caminhando, para ter acesso às diversas atividades presentes nestas áreas. Pequenos estabelecimentos comerciais e de serviços são exemplos de locais de destino de quem caminha nestes locais, além do acesso ao transporte público e às áreas residenciais dispersas no território. Na Figura 26, é possível observar pedestres caminhando pela Estrada da Rhodia, que conecta Paulínia ao distrito de Barão Geraldo, passando por áreas com diversos condomínios fechados de alto padrão. O passeio é precário, dos dois lados da via, ainda que o espaço para os automóveis seja qualificado.

Outra situação bastante comum na região, é a presença dos pedestres nas áreas industriais, com fluxo considerável, principalmente junto aos acessos ao transporte público. Os motoristas de caminhão que estacionam nessas áreas também circulam entre as empresas, por diversos motivos, sendo necessário utilizar os espaços de transição da rodovia para caminhar. As marcações na grama, observadas na Figura 27 demonstram que os fluxos de pedestre existem e são constantes.
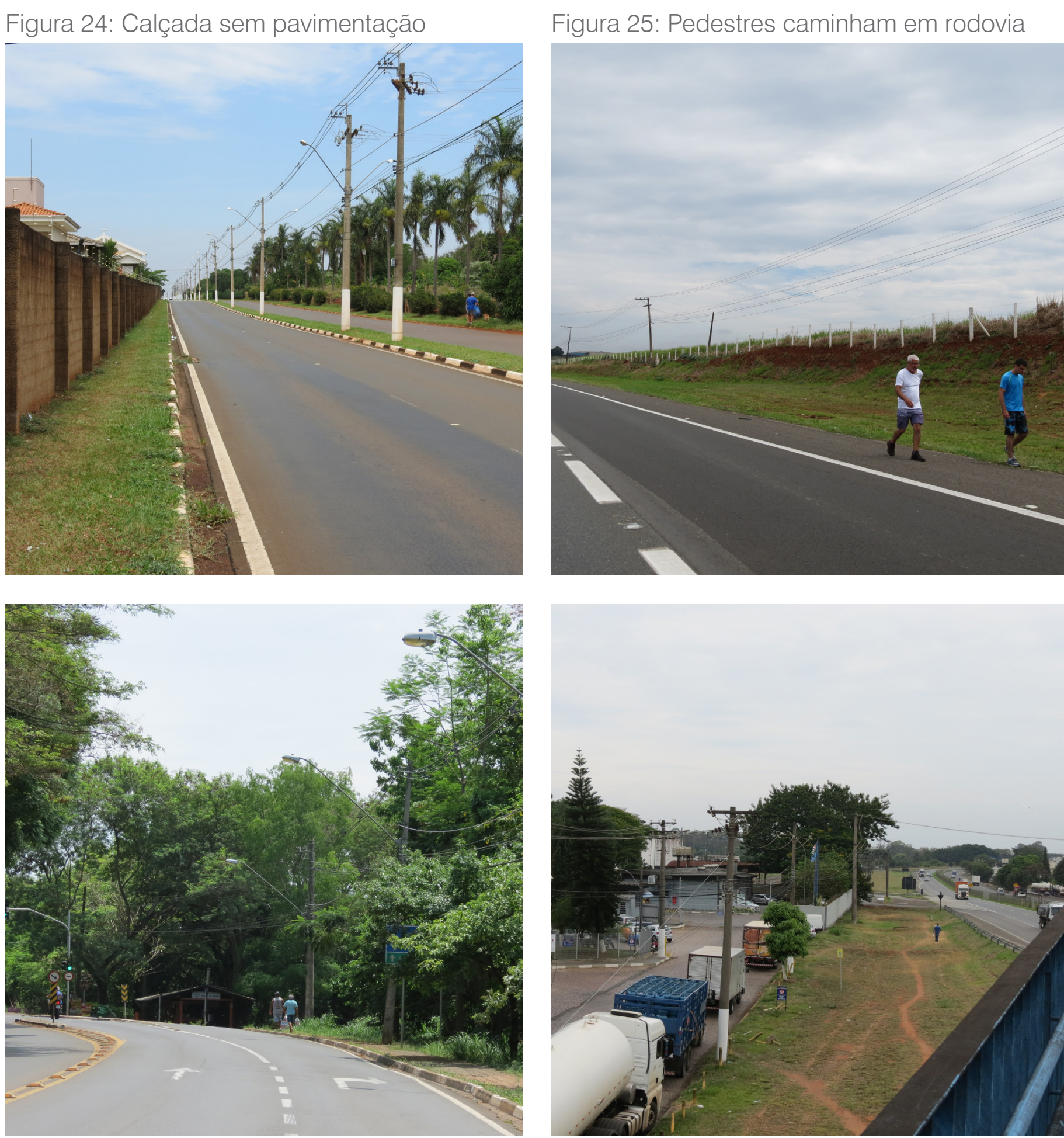

Figura 26: Pedestres caminham em estrada

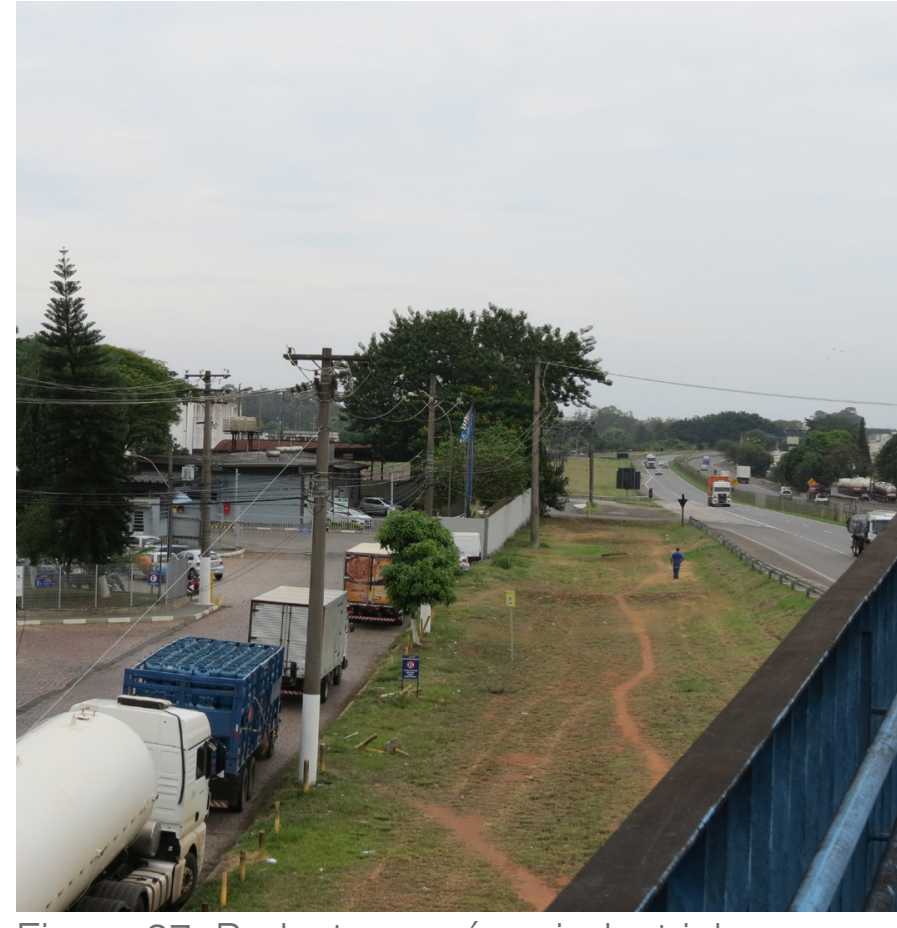

Figura 27: Pedestre em área industrial 
Ainda que o espaço para os pedestres seja precário ou inexistente, na maior parte dos casos, nos trechos de rodovia próximos aos núcleos urbanos consolidados é possível reconhecer tentativas de integrar o pedestre ao ambiente destas vias, principalmente por causa da dispersão urbana, que obriga a implantação de soluções não tradicionais.

Na Figura 28, por exemplo é possível observar que o pedestre caminha por uma calçada na lateral da Rodovia SP-332, que dá acesso à uma passarela, que é a única possibilidade de acesso à um bairro afastado do núcleo urbano consolidado da cidade de Cosmópolis. Ainda que este trecho possua iluminação, pavimentação e proteção em relação ao trânsito de alta velocidade, o ambiente é árido, com extensão aproximada de 400 metros.

Desta mesma forma, é possível observar que no trecho da rodovia próximo à Betel, mostrado na Figura 29, existe um caminho que permite o acesso ao ponto de ônibus metropolitano. A calçada se localiza em uma latera da Rodovia SP-332, protegida do fluxo de veículo por defensas metálicas (guard rail), passando sobre túnel de automóveis para cruzamento da rodovia. Essa calçada dá continuidade à passarela, de onde a foto foi tirada Esse caminho, em dias de chuva ou à noite é ainda menos convidativo e seguro do que no horário em que a situação foi observada, mostrando que, ainda que exista espaço para o deslocamento a pé, o conforto não foi considerado na implantação desta solução.

A falta de conforto para o pedestre nestas vias também prejudica o cotidiano da população que as utilizam. A Figura 30 mostra que o caminho diário das crianças para a escola também é a pé, principalmente das que habitam as cidades menores. Na imagem, as crianças, acompanhadas pelos pais, atravessam a rodovia utilizando a passarela, que chega em espaço livre, como uma praça. No entanto, os caminhos estampados na grama pelo fluxo de pessoas permite compreender que este espaço não foi projetado para o fluxo que recebe. Isso mostra que esses trajetos cotidianos não recebem atenção devida, ainda que sejam visíveis na paisagem e envolvam a segurança das crianças.

Figura 28: Pedestre caminha em calçada na lateral da Rodovia SP-332

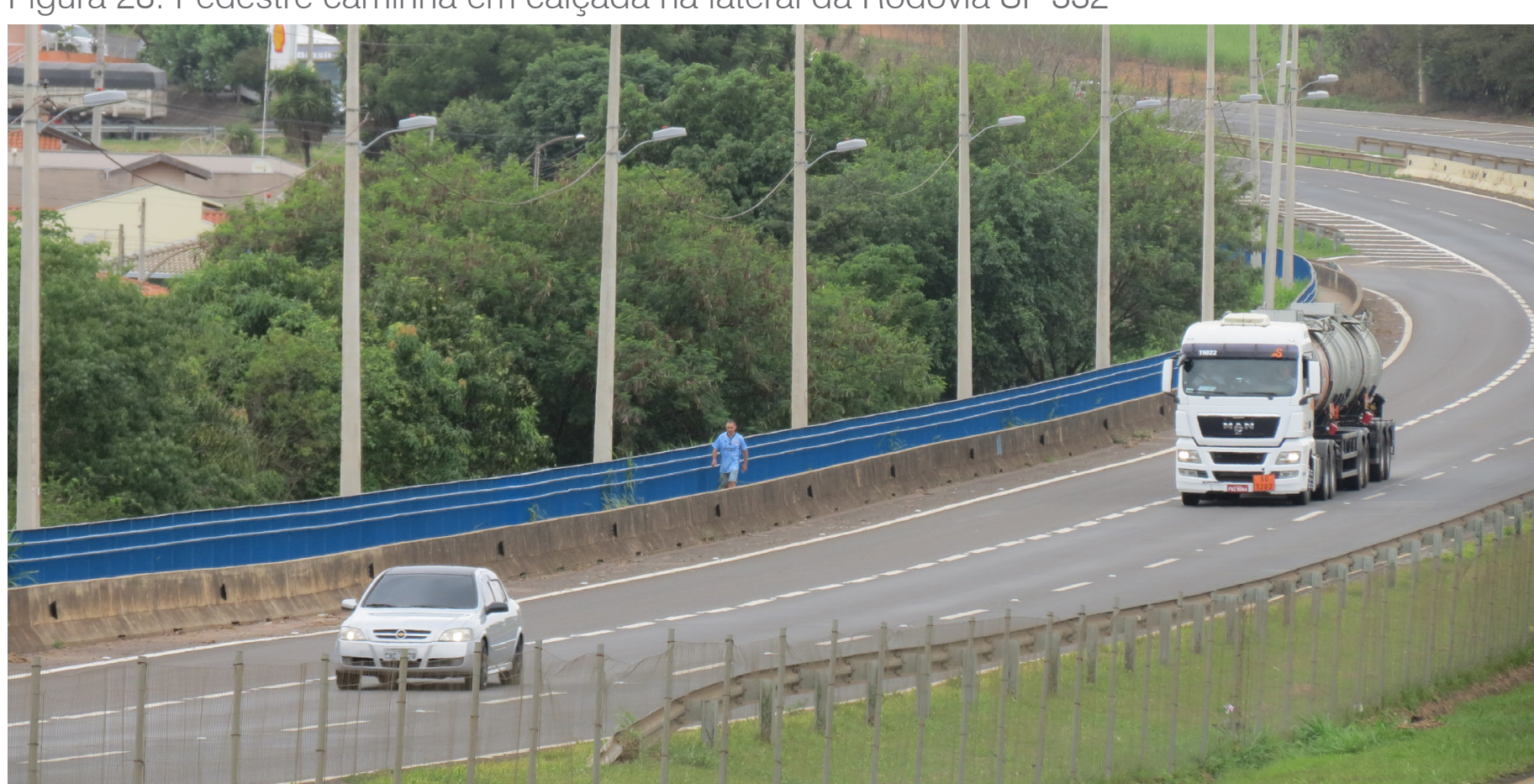

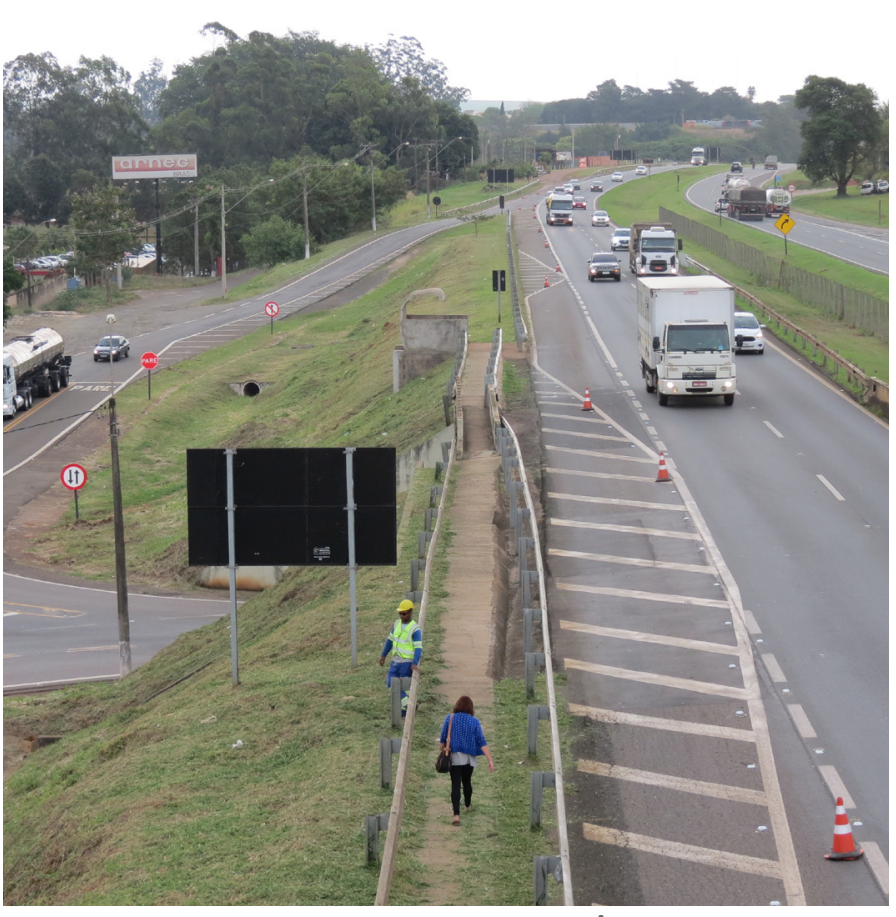

Figura 29: Acesso ao ponto de ônibus

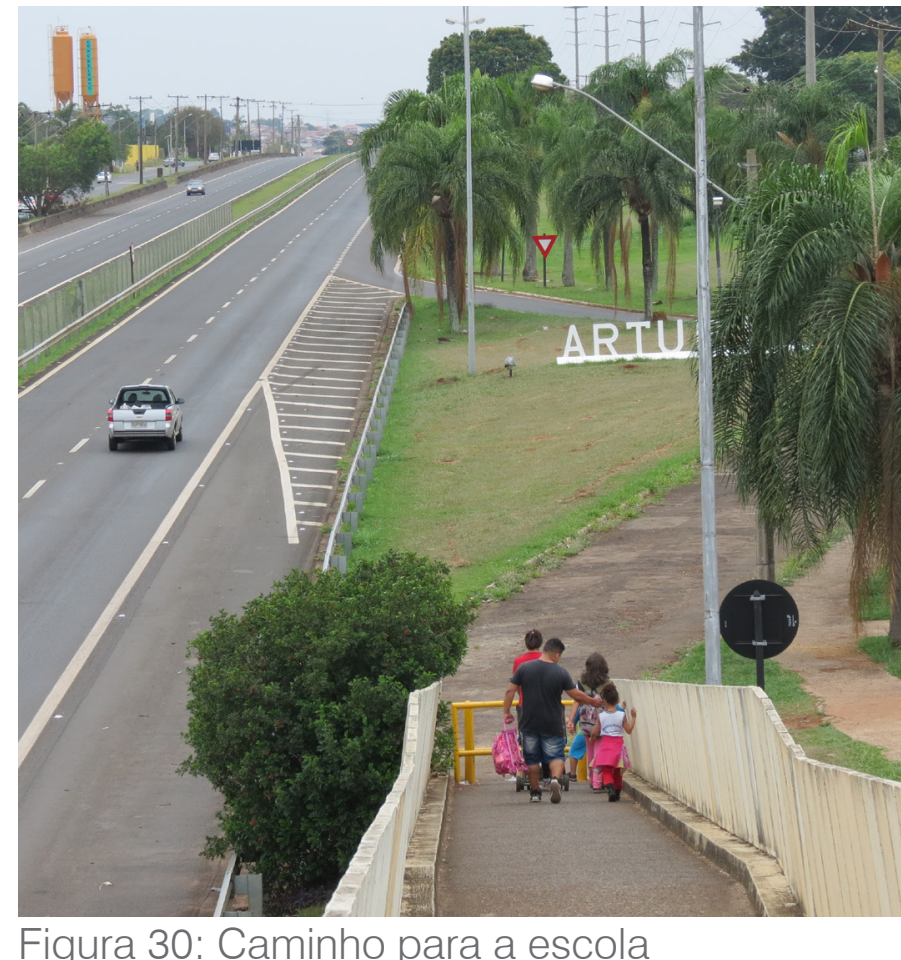

Figura 30: Caminho para a escola 


\section{Bicicleta}

Segundo a Pesquisa Origem-Destino de 2011 para a RMC, a justificativa para a opção de viagens a pé ou bicicleta tem como maior motivo a pequena distância entre as viagens. Também foram citados aspectos de oferta de transporte, como a demora para que a condução passar ou a ausência do atendimento de transporte em algumas áreas.

Ou seja, o uso da bicicleta na região é de grande importância no cotidiano da população visto que, além de cumprir sua função, de vencer distâncias menores, com menor custo para o usuário, ainda serve de meio alternativo aos transportes que alcançam distâncias maiores, mas tem pouca eficiência no território metropolitano. Seu papel no transporte de integração entre a casa e o ponto de ônibus também deve ser ressaltado. Essa condição foi identificada nas entrevistas realizadas para este trabalho.

Nas cidades menores como Artur Nogueira, Cosmópolis e Engenheiro Coelho, que apresentam terrenos mais planos, as bicicletas estão mais presentes no espaço intraurbano, nos deslocamentos cotidianos e nos trajetos de acesso às áreas dispersas, pelas vias metropolitanas e estradas. A Figura 31, por exemplo, mostra um paraciclo instalado em praça próxima ao ponto de ônibus intermunicipal, na saída da cidade de Cosmópolis, em direção à Paulínia e Campinas. Ele serve principalmente às pessoas que se deslocam das suas casas pela manhã para tomar o ônibus para o trabalho e são retiradas à noite, no retorno do trabalho.

Nos núcleos urbanos consolidados, em vias praticamente planas, é comum observar ciclistas realizando trajetos cotidianos, ainda que não existam ciclovias ou ciclofaixas. Nesse caso, a bicicleta ocupa a lateral da via, dividindo-a com espaços de estacionamento de veículos e outros obstáculos, como caçambas. A Figura 32 mostra uma via metropolitana secundária da cidade de Cosmópolis, na qual é possível observar dois ciclistas pedalando em local sem infraestrutura adequada.

Os deslocamentos por meio de bicicleta também estão presentes em área próxima aos condomínios, como é possível observar na Figura 33. Ela

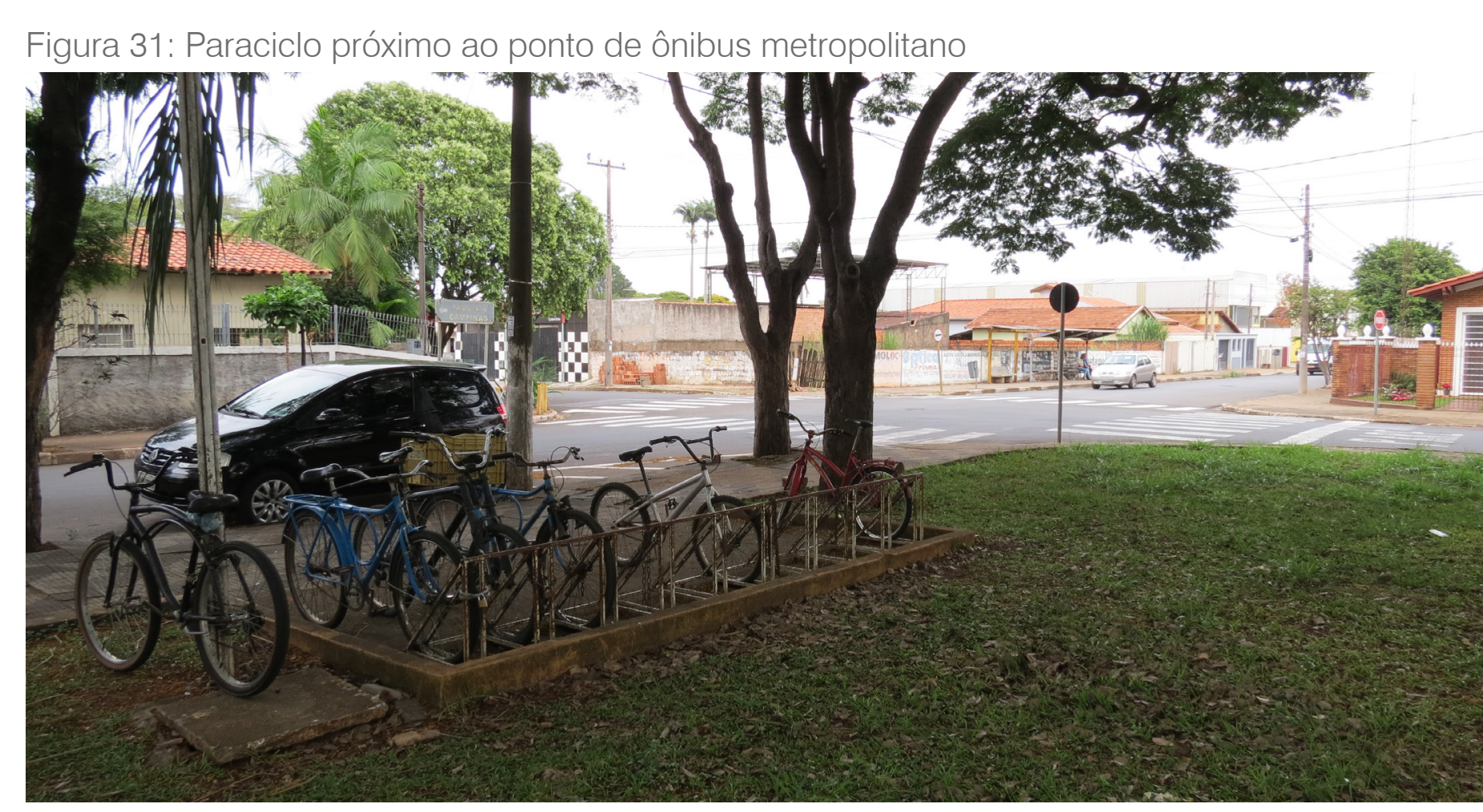

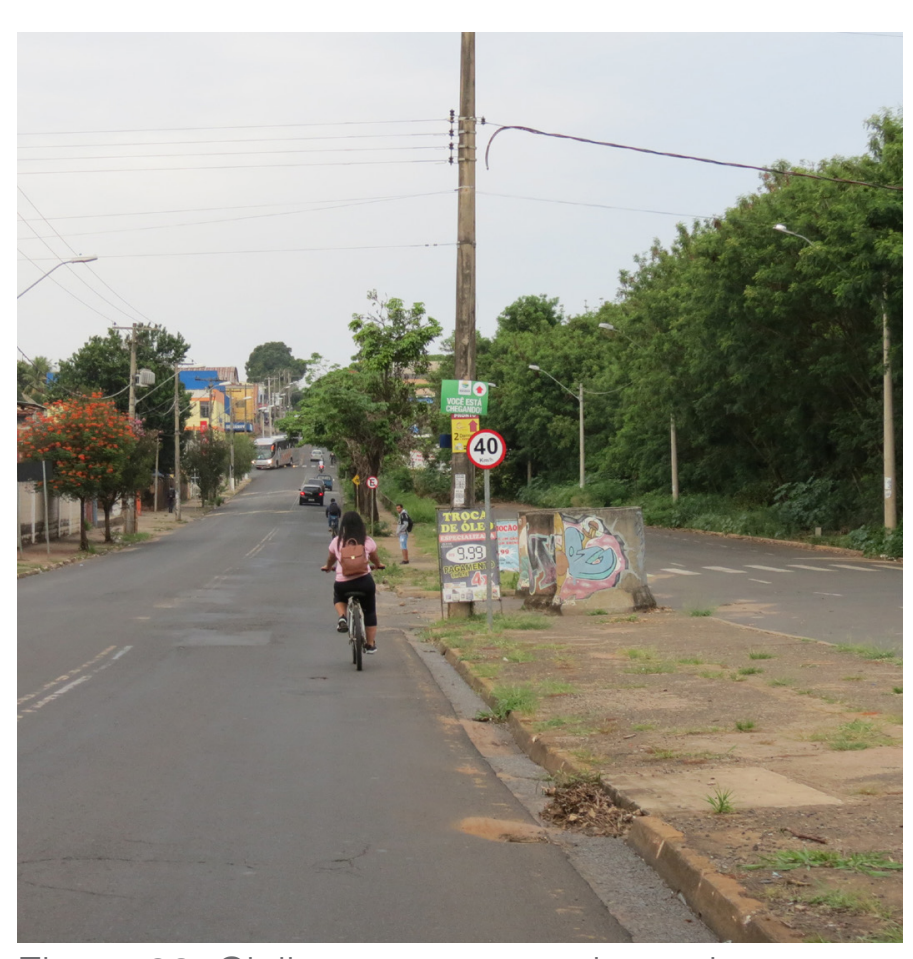

Figura 32: Ciclistas no espaço intraurbano

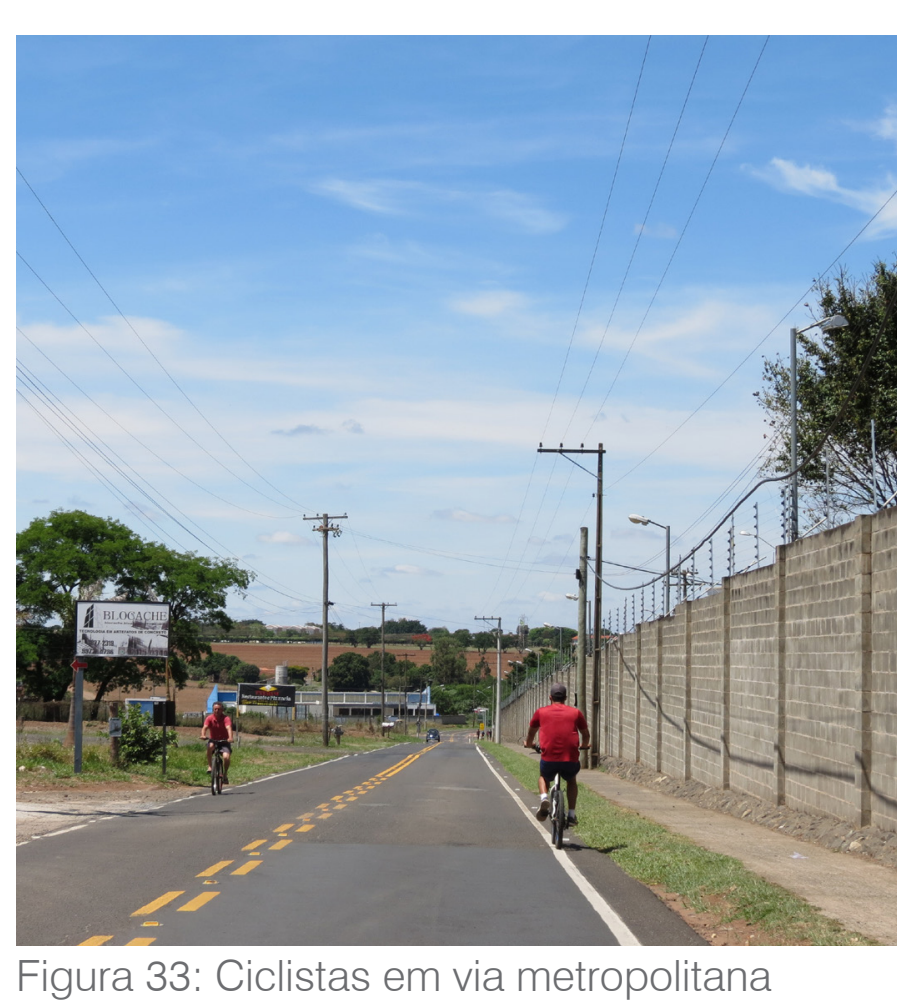


mostra dois ciclistas em Engenheiro Coelho, indo e voltando do pequeno núcleo comercial, próximo desta área, por meio de uma via metropolitana Ainda que a cidade possua um sistema de ciclovias, localizado no núcleo urbano consolidado, neste trecho não existe qualquer infraestrutura voltada à bicicleta.

Nas estradas, em meio predominantemente rural, também é possíve encontrar ciclistas, que geralmente residem ou trabalham nestes locais No entanto, como mostra a Figura 34, é possível observar que não apenas não há infraestrutura para os ciclistas como não existe espaço alternativo que possa ser aproveitado, sendo, assim, necessário ocupar parte da via destinadas aos veículos motorizados. As vias macro metropolitanas também servem aos deslocamentos dos pequenos agricultores, que são usuários de bicicleta, para se deslocar entre o local de moradia e os núcleos urbanos dispersos. Na imagem, o ciclista carrega produtos agrícolas, em direção à Engenheiro Coelho, utilizando o acostamento da Rodovia SP-332 como espaço de circulação.

Em Paulínia e Campinas, diferente das cidades menores, é possível dizer que as bicicletas, nas vias metropolitanas, são mais comuns com os ciclistas de final de semana, que geralmente percorrem grandes distâncias, por esporte, como pode ser visto na Figura 36. Estes ciclistas geralmente estão acompanhados e trajados com roupas específicas, além de levarem equipamentos de proteção. Estão mais presentes na rodovia que possui melhor pavimentação, com exceção dos ciclistas de aventura que percorrem as áreas rurais.

Ainda assim, é possível observar ciclistas que percorrem grandes distâncias em percursos do cotidiano. Os deslocamentos diários por bicicleta não acontecem apenas nos espaços intraurbanos. A Figura 37 mostra um ciclista com trajes comuns pedalando na Rodovia SP-332, em trecho entre Paulínia e Campinas. Ao observar o deslocamento, não foi possíve identificar o seu destino final, mas é possível estimar que percorreu uma longa distância, sempre pelo acostamento, sem infraestrutura específica ou dispositivos de proteção em relação aos veículos em alta velocidade.

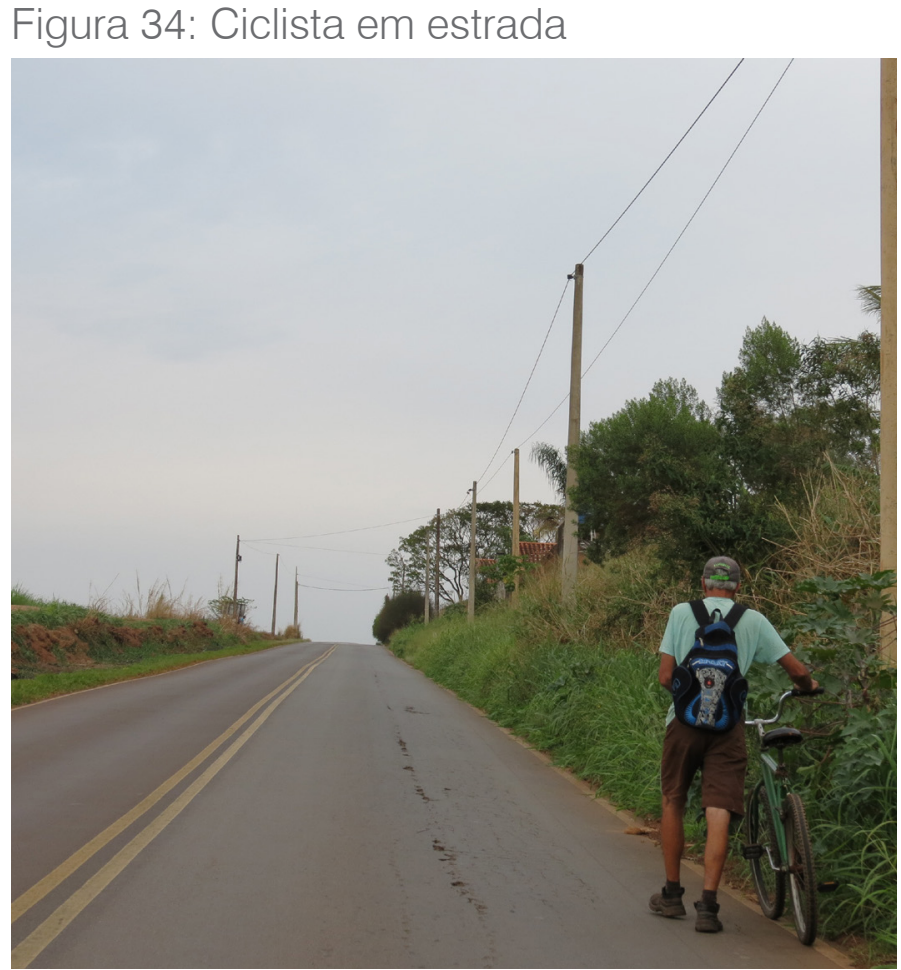

Figura 35: Produtor agrícola pedalando

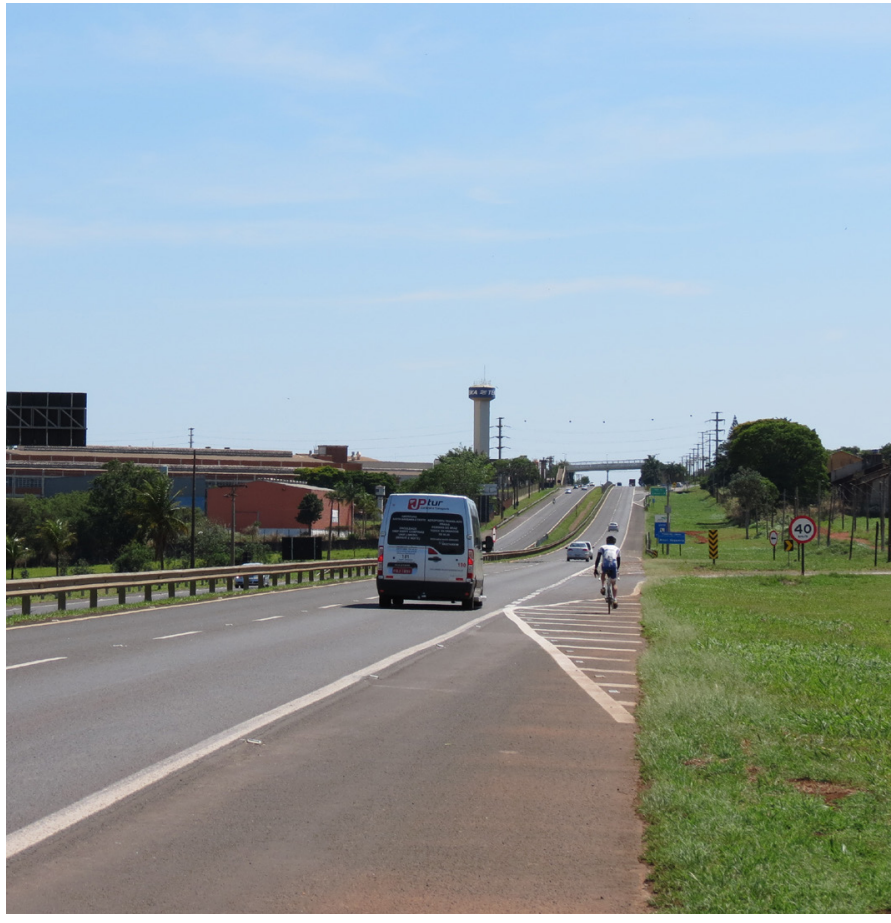

Figura 36: Ciclista de final de semana
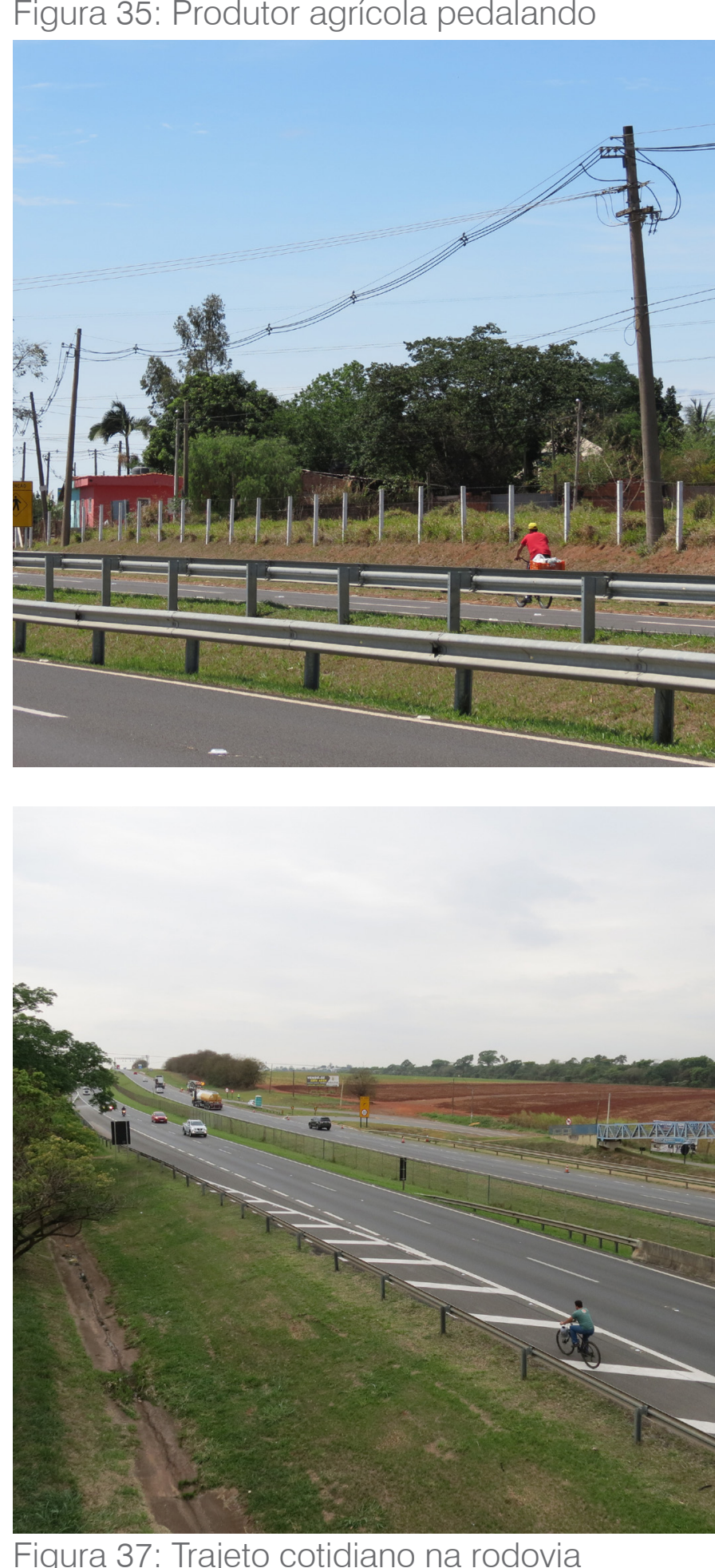


\section{TRANSPORTE PÚBLICO COLETIVO}

O sistema de transporte público coletivo da RMC é composto unicamente por ônibus metropolitanos. Ainda que fiscalizado e regulamentado pela Empresa Metropolitana de Transportes Urbanos (EMTU), as linhas que percorrem a região são operadas por concessionárias. O sistema cobre todo o território metropolitano e se utiliza das rodovias como eixos estruturadores das linhas, conforme pode ser observado na Figura 38.

A estrutura do sistema é radial, sendo possível observar a predominância de Campinas como destino das linhas e a fraca interação entre as cidades menores, com poucas ligações em estrutura anelar, com percursos fragmentados. É possível observar, ainda, a concentração de linhas no vetor noroeste em direção à Americana, que tem como função atender à maior concentração populacional da região, com baixa renda.

Nas entrevistas realizadas em campo, foi possível perceber que o transporte público coletivo do Vetor 3 está diretamente relacionado às dinâmicas industriais da região metropolitana. Os fatores que mostram essa condição são os horários de maior operação das linhas, alinhados com as entradas e saídas de turnos de trabalhadores das empresas localizadas nas rodovias ou nos comércios e serviços de Paulínia e Campinas. Ainda assim, os ônibus nestes horários circulam com superlotação.

Outro fator que demonstra essa condição é a estrutura radial do sistema demonstrado na dificuldade de deslocamento no território por umas das entrevistadas. Ela estava se deslocando de Sumaré até Cosmópolis. Para isso, teve que ir até o centro da cidade de Campinas e trocar de ônibus, para seguir até Cosmópolis. Por estar fora do horário de pico, teve que esperar mais de 30 minutos para realizar a integração entre os ônibus.

No Vetor 3, são 13 as linhas metropolitanas, que fazem trajetos entre Campinas e Engenheiro Coelho, listadas na Tabela2. Algumas delas fazem trajetos com acesso aos distritos de Barão Geraldo e Betel, mas possuem baixa frequência, estando os horários de operação concentrados nos horários industriais.

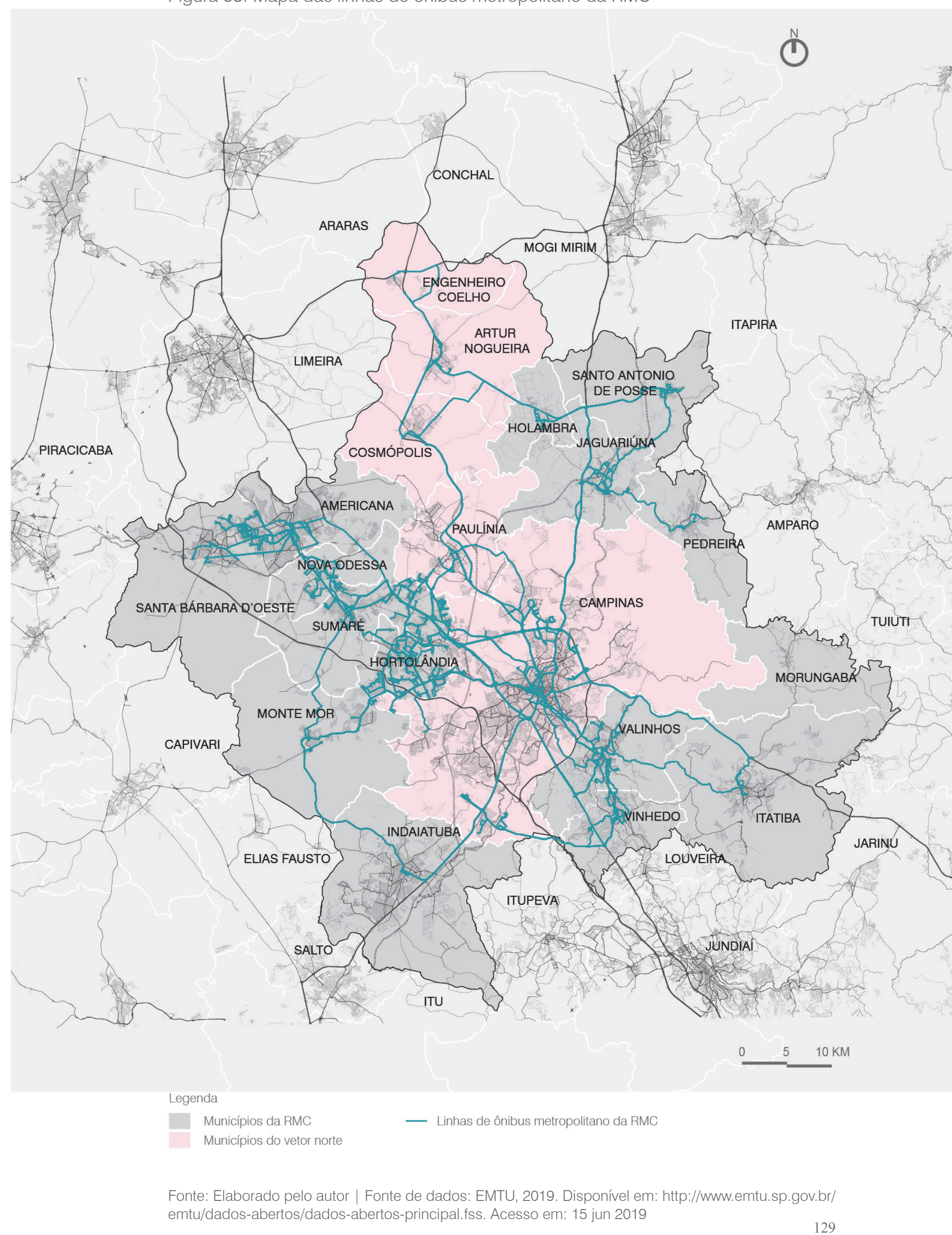


Tabela2: Tabela de linhas de ônibus metropolitano do Vetor 3

\begin{tabular}{|c|c|c|c|}
\hline & No da Linha & Origem & Destino \\
\hline \multirow{2}{*}{$\begin{array}{l}\tilde{N} \\
\text { p. } \\
i d \\
i \infty\end{array}$} & 737 & Terminal Rodoviário de Cosmópolis & Centro de Holambra \\
\hline & 606 & Terminal Rodoviário de Cosmópolis & $\begin{array}{c}\text { Terminal Prefeito Magalhães Teixeira em } \\
\text { Campinas }\end{array}$ \\
\hline \multirow{5}{*}{ 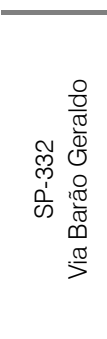 } & $606 \mathrm{DV} 1$ & Terminal Rodoviário de Cosmópolis & $\begin{array}{l}\text { Terminal Prefeito Magalahäes Teixeira em } \\
\text { Campinas }\end{array}$ \\
\hline & $606 \mathrm{EX} 1$ & $\begin{array}{l}\text { Bairro Coraçăo Criançaa } \\
\text { Artur Nogueira }\end{array}$ & $\begin{array}{l}\text { Terminal Prefeito Magalhāes Teixeira em } \\
\text { Campinas }\end{array}$ \\
\hline & 607 & Terminal Rodoviário de Cosmópolis & $\begin{array}{l}\text { Shopping Parque Dom Pedro em } \\
\text { Campinas }\end{array}$ \\
\hline & 604EX1 & Paulínia Rodoviária Shopping & $\begin{array}{l}\text { Shopping Parque Dom Pedro em } \\
\text { Campinas }\end{array}$ \\
\hline & 604DV1 & Paulinia Rodoviária Shopping & $\begin{array}{c}\text { Terminal Prefeito Magalhāes Teixeira em } \\
\text { Campinas }\end{array}$ \\
\hline \multirow{3}{*}{ 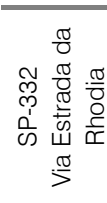 } & 744 & Terminal Rodoviário de Cosmópolis & $\begin{array}{l}\text { Terminal Prefeito Magalhāes Teixeira em } \\
\text { Campinas }\end{array}$ \\
\hline & 605 & Paulínia Rodoviária Shopping & $\begin{array}{l}\text { Terminal Prefeito Magalhäes Teixeira em } \\
\text { Campinas }\end{array}$ \\
\hline & 609 & Paulínia Rodoviária Shopping & Terminal Rodoviário de Cosmópolis \\
\hline \multirow{3}{*}{ 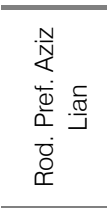 } & 693 & Bairro CDHU em Artur Nogueira & $\begin{array}{c}\text { Terminal Prefeito Magalhães Teixeira em } \\
\text { Campinas }\end{array}$ \\
\hline & 608 & Bairro Vila Fontana em Cosmópolis & $\begin{array}{l}\text { Terminal Rodoviário de } \\
\text { Engenhhiro Coello }\end{array}$ \\
\hline & 604 & Paulinia Rodoviária Shopping & $\begin{array}{l}\text { Terminal Prefeito Magalhäes Teixeira em } \\
\text { Campinas }\end{array}$ \\
\hline
\end{tabular}

Fonte: EMTU, 2019. Disponível em http://mww.emtu sp.gov.br/emtu/tinerarios-e-tarifas/consulteorigem-e-destino/por-egia-metropoltana tss Acesso emi 10 out 2019

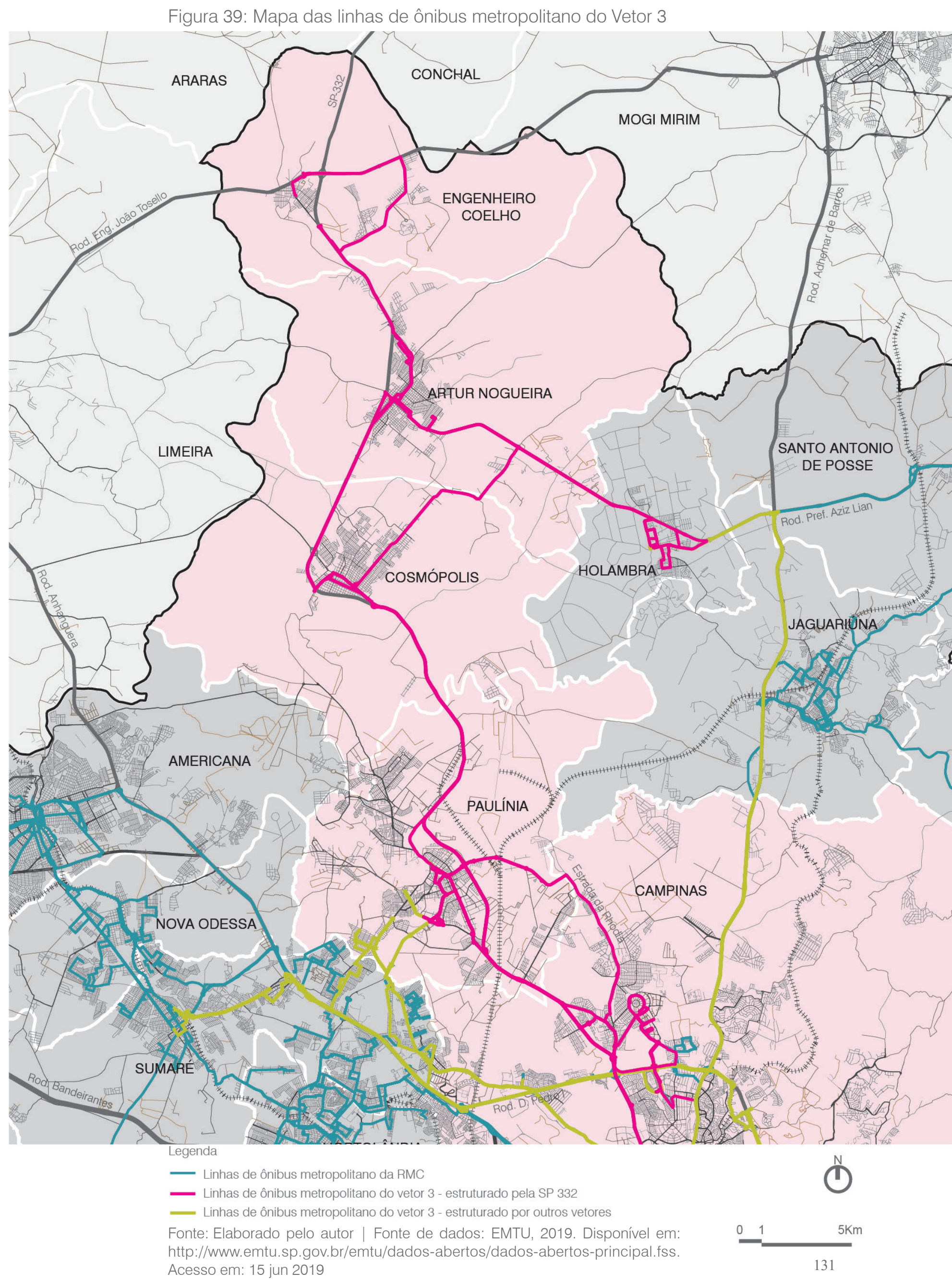


As tarifas dos ônibus metropolitanos do Vetor 3 estão acima de $\mathrm{R} \$ 5,00$ para distâncias mais curtas como no trecho entre Artur Nogueira e Cosmópolis, acima de $R \$ 7,00$ em distâncias maiores, como entre Cosmópolis e Campinas, podendo chegar a aproximadamente $R \$ 12,00$ nos trechos ainda mais longos, como entre Artur Nogueira e Campinas.

A Figura 39 mostra os locais por onde os ônibus metropolitanos passam, ocupando as vias classificadas pelo SIVIM como de interesse metropolitano. Em destaque, em rosa, as linhas que têm integração com a Rodovia SP-332, estruturadora do Vetor 3, objeto de estudo desta pesquisa. Em amarelo, as linhas metropolitanas que têm origem ou destino as cidades do Vetor 3, mas que se utilizam de outras rodovias - ou outros vetores nos seus trajetos. Por este mapa, é possível perceber que o sistema se organiza de forma radial, com apenas duas alternativas de circulação na transversal da Rodovia SP-332, com acesso por Holambra ou Sumaré

Apesar de ocupar todas as vias de caráter metropolitano, os ônibus metropolitanos, no Vetor 3, possuem pouca capilaridade, se comparado aos trajetos existentes nas linhas do vetor noroeste. Assim, as áreas de dispersão urbana demandam outros meios de transporte para serem acessadas. Essa capilaridade pode ocorrer por meio ônibus municipal na maior parte das cidades. Em Engenheiro Coelho, no entanto, isso não é possível, visto que a cidade não fornece este serviço à população (PASQUOTTO et al., 2018). Dessa forma, o transporte individual, motorizado ou não, é necessário para complementar o transporte metropolitano.

Ainda que não percorre muitas ruas nas cidades, os ônibus metropolitanos passam pelas principais avenidas. A Figura 40, mostra, por exemplo, o embarque de passageiros no espaço intraurbano da cidade de Cosmópolis, em via metropolitana secundária. Nesta mesma linha, a Figura 41 mostra ponto de parada de ônibus metropolitano na Rodovia SP-332, em área industrial, em via macro metropolitana. Apesar de, neste caso possuir área de aproximação do ônibus reservada da rodovia, nem sempre essa situação se repete, sendo o embarque realizado em área demarcada no acostamento da rodovia.
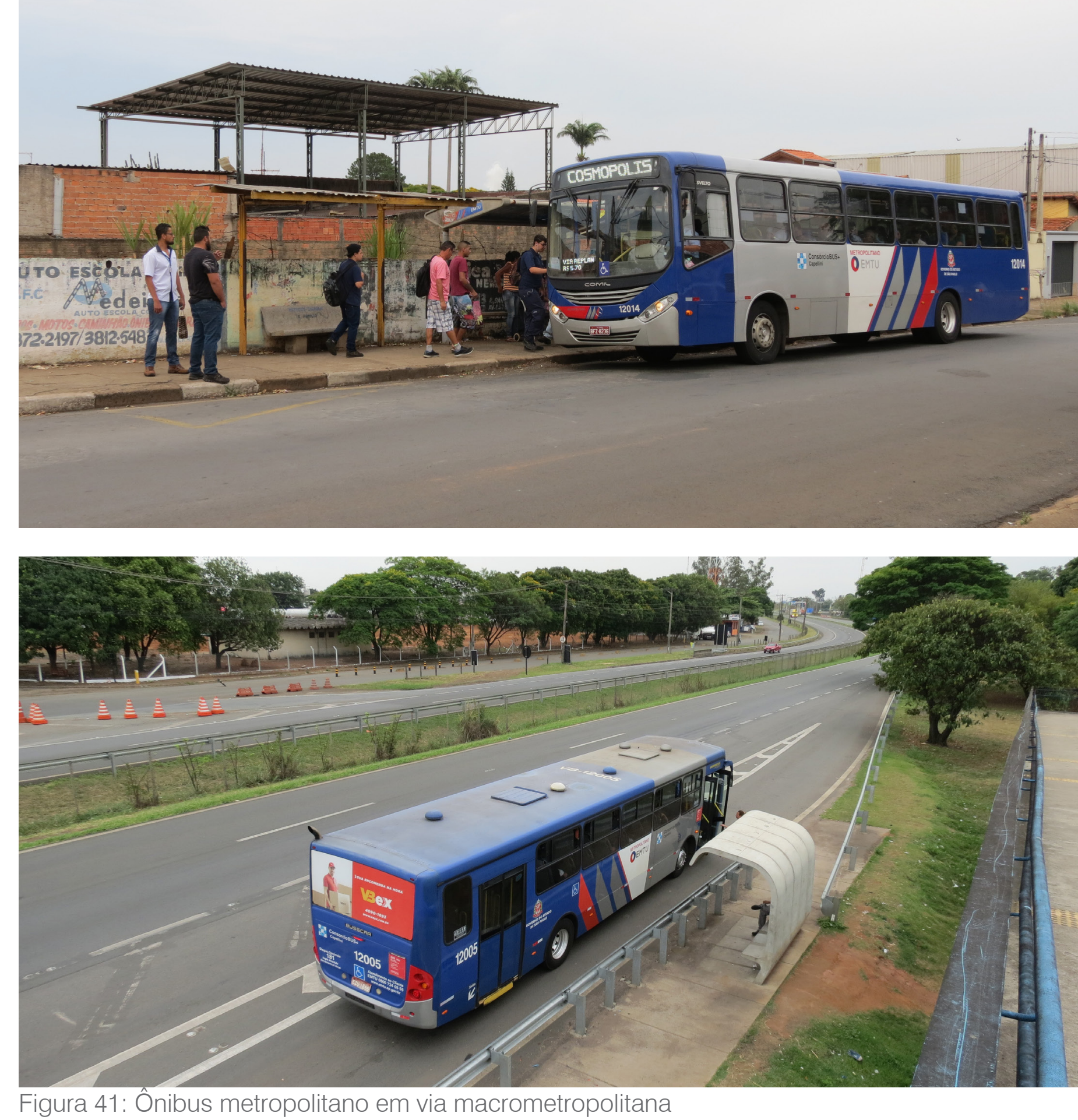


\section{TRANSPORTE COLETIVO PARTICULAR}

\section{Ônibus e van escolar}

Como aponta a Pesquisa Origem-Destino de 2011 (EMPLASA, 2012), as viagens por motivo estudo e trabalho são as duas mais importantes na RMC. Trabalho tem participação de 45,5\% e estudo, 21,2\% do total de viagens. Para suprir essa demanda de viagens, muitas vezes o transporte escolhido (ou necessário) é feito por ônibus e vans fretados. Escolhidos pela comodidade de acesso em horários específicos, não dependendo do sistema de transporte público tão pouco eficiente, os fretados atendem os exigentes horários de aula, que nem sempre coincidem com os horários de serviço dos ônibus metropolitanos e municipais.

As cidades do Vetor 3 oferecem transporte gratuito para os alunos das redes municipais e estaduais, dentro da própria cidade, em nível fundamental e médio de ensino. Geralmente efetuados por ônibus, os trajetos se restringem ao município, não servindo às cidades vizinhas. No entanto, os trajetos internos ao município nem sempre se restringem às vias do núcleo urbano consolidado, visto que a dispersão da mancha urbana obriga os ônibus a se utilizarem das rodovias para acessar trechos afastados. Na Figura 42, um ônibus escolar de Paulínia circula pela Rodovia SP-332, ainda que os alunos sejam moradores e estudantes da própria cidade.

Para o ensino superior, o transporte geralmente é fretado, sem subsídio do estado, pago pelos próprios estudantes. As universidades particulares são os principais atrativos desses alunos, que moram em toda a região e necessitam desse tipo de transporte principalmente no período noturno, quando o transporte coletivo público não funciona. Nesse caso, as rodovias são essenciais, uma vez que as universidades se localizam em diversos municípios, de toda a região, como é o caso da Centro Universitário Adventista de São Paulo (UNASP), em Engenheiro Coelho ou a Universidade Estadual de Campinas (UNICAMP), em Barão Geraldo.
A Figura 43 mostra van fretada que partiu da cidade de Artur Nogueira com destino a UNASP, circulando pela Rodovia SP-332. Essa dinâmica dos fretados colabora na compreensão dos movimentos pendulares da RMC, que são sua característica principal, nos quais ao invés de mudar seu local de moradia, o cidadão metropolitano se desloca pelo território diariamente.

Figura 42: Ônibus escolar circulando pela SP-332, em Paulínia
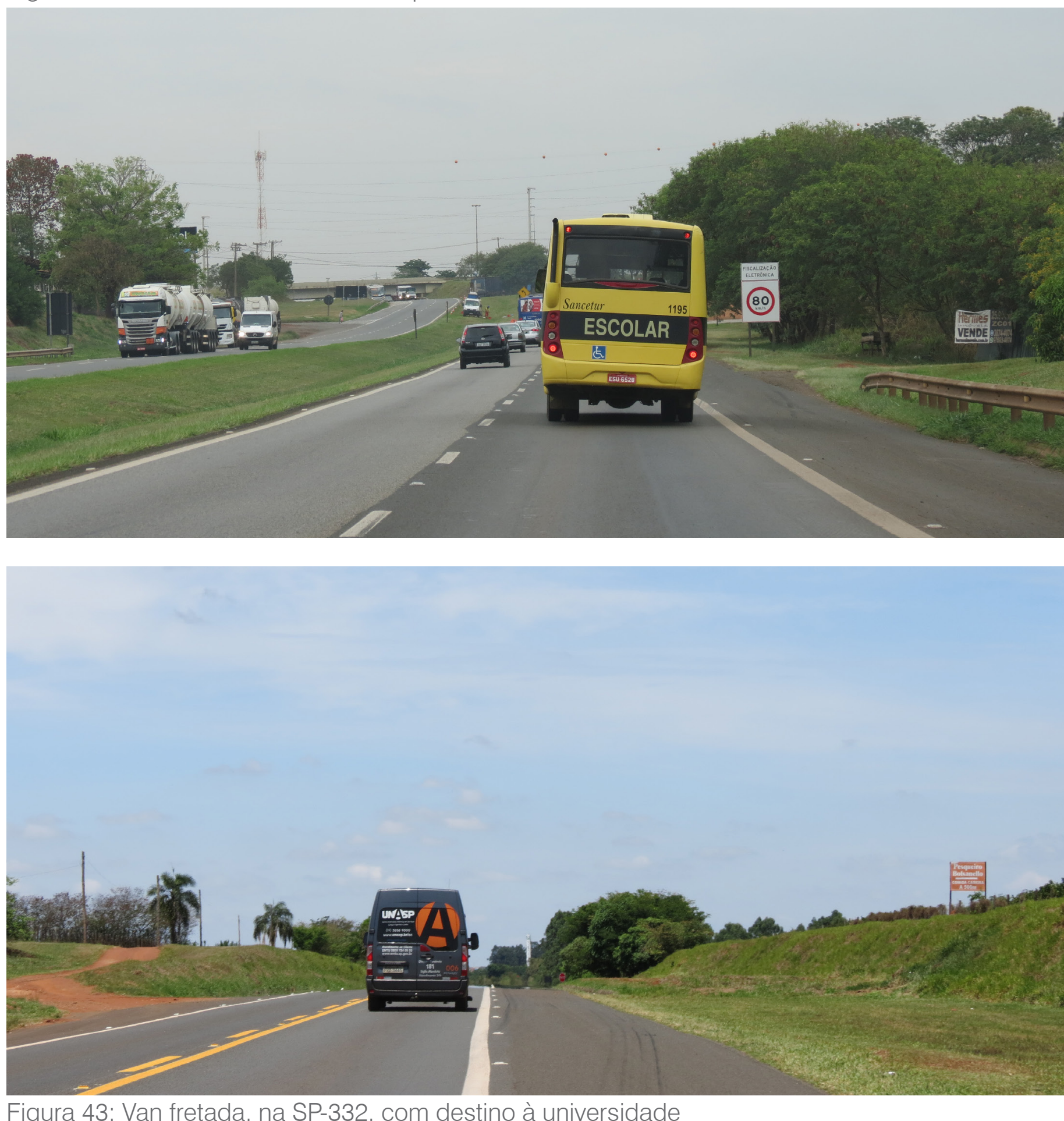

Figura 43: Van fretada, na SP-332, com destino à universidade 


\section{Ônibus fretados}

Da mesma forma que o "estudo" motiva as viagens e induz a existência de um meio de transporte específico, o "trabalho" também contribui com os meios alternativos de transporte da RMC.

De acordo com Sobreira (2007), o transporte coletivo é predominante em cidades pequenas como Artur Nogueira, Cosmópolis e Engenheiro Coelho. Enquanto isso, os municípios maiores têm maior proporção de uso de ônibus comum. É possível que essa condição ocorra pela falta de linhas que supram as necessidades dos deslocamentos pendulares nessas cidades, dada a sua distância em relação à cidade sede ou as áreas de atratividade de viagens, como os polos tecnológicos, localizados entre as cidades maiores.

O ônibus fretado pode ser organizado pelos próprios usuários, dada a necessidade de meios alternativos de transporte ou pelos empregadores, com o fornecimento de meio de transporte específico para os empregados de determinada empresa ou indústria.

Na pesquisa realizada em campo, foi interessante notar que algumas pessoas utilizavam dos dois meios de transporte para se locomover durante o dia. Um estudante, por exemplo, pode se utilizar do ônibus metropolitano para ir até o estágio durante o dia e usar de ônibus fretado durante a noite, para ir à faculdade.

Para os trabalhadores, a vantagem de usar os ônibus fretados é que na maior parte das vezes estes são pagos pelo empregador, ou até mesmo disponibilizados pelas empresas, reduzindo gastos com deslocamento, incluindo os pedágios existentes na região.

Os fretados se deslocam por todo o território do Vetor 3. Na Figura 44 é possível ver ônibus fretado circulando em área urbana, demonstrando sua maior capilaridade na área urbana e maior comodidade para os funcionários que não precisam se direcionar aos pontos de ônibus, geralmente localizados nas maiores avenidas.

Figura 44: Ônibus fretado em via do espaço intraurbano
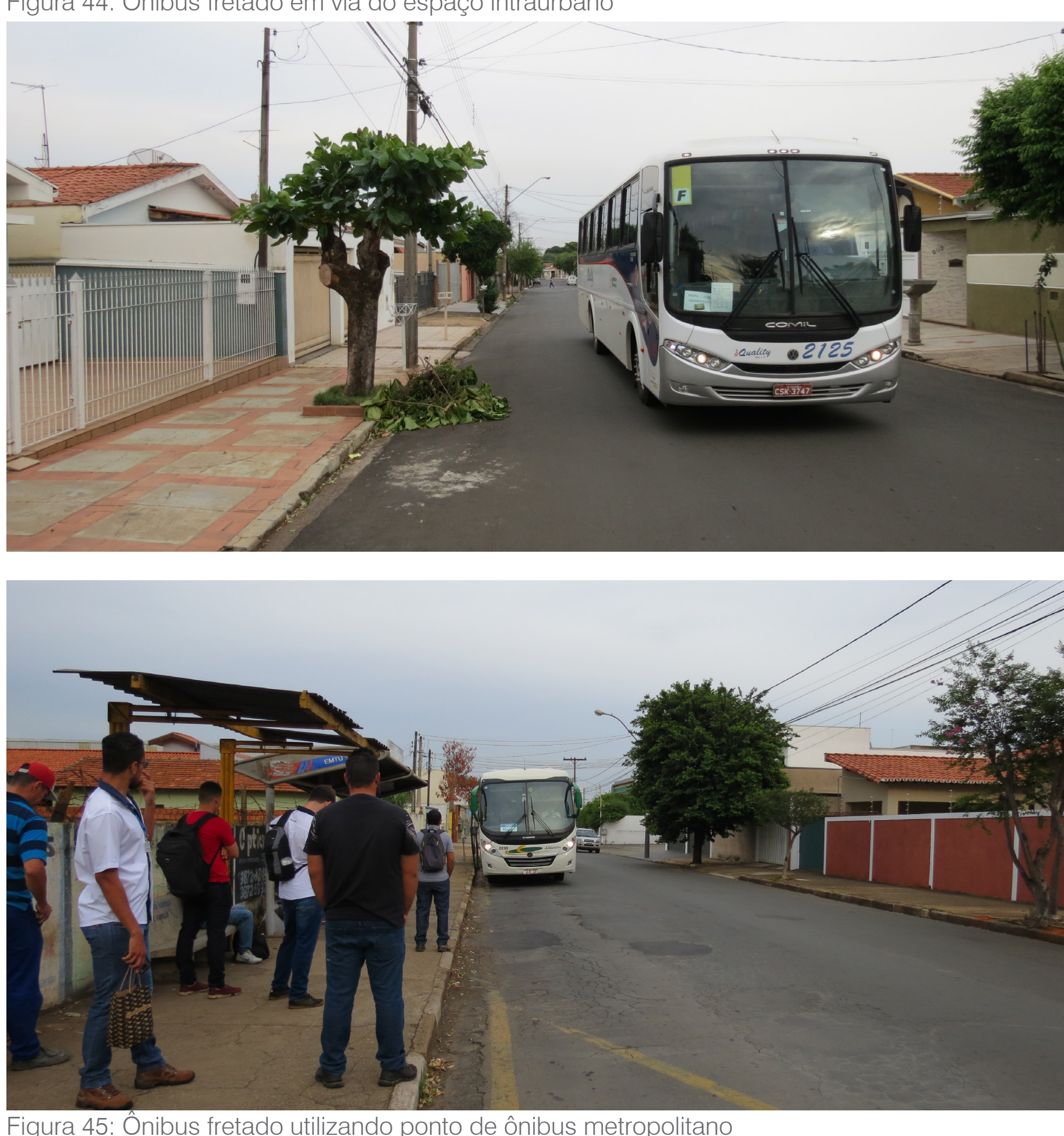
No entanto, apesar de possibilitar realizar trajetos em que passem próximos às casas dos funcionários, muitos fretados se utilizam dos pontos de ônibus metropolitano como referência e ponto de encontro dos usuários. No caso da Figura 45, o ônibus faz o embarque de funcionários de uma empresa localizada na SP-332, utilizando-se de ponto próximo à saída da cidade de Cosmópolis, em via metropolitana secundária.

É comum encontrar ônibus fretados circulando pelas rodovias, principalmente nas áreas industriais, que são as maiores atratoras desse tipo de viagem, como mostrado na Figura 46, na qual o ônibus circula pela área industrial próxima à cidade de Paulínia. Outra vantagem em relação ao transporte público é que o usuário do fretado não precisa realizar o trajeto do ponto de ônibus até sua empresa, que geralmente possuem infraestrutura precária.

Além de usar dos pontos de ônibus metropolitano como local de encontro, os fretados acabam por realizar, também, os mesmos trajetos, utilizando da rodovia para acessar o seu destino final, como pode ser visto na Figura 47. A foto foi realizada do interior de um ônibus metropolitano, que realiza trajeto entre Cosmópolis e Campinas, pela SP-332 A diferença entre esses meios de transporte são o fato de que os horários dos fretados são mais flexíveis e que estes possibilitam acessar lugares mais específicos.

Figura 46: Ônibus fretado em área industrial, na rodovia SP-332
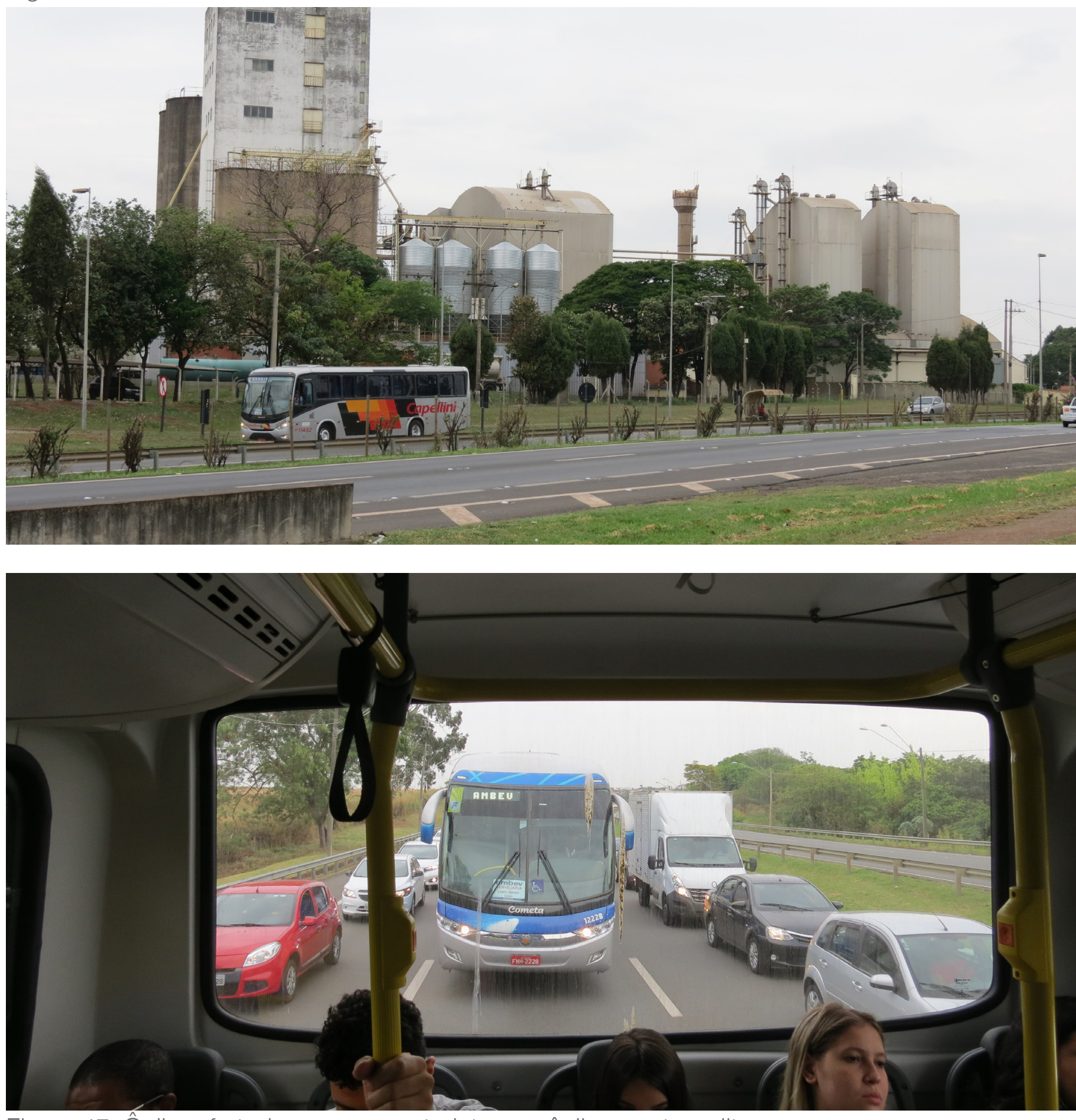


\section{TRANSPORTESDECARGA-RODOVIÁRIOEFERROVIÁRIO}

\section{Caminhões de carga e caminhões de pequeno porte}

O transporte de cargas na Região Metropolitana de Campinas ocorre de forma predominante pelo sistema rodoviário, por meio de caminhões. Segundo a EMPLASA (2018b, p.64), "a circulação de cargas responde por $28 \%$ da movimentação diária dos veículos que entram ou saem da RMC, sendo que a maior parte delas (64\%) é composta por caminhões de carga pesada (três eixos ou mais). A maior conexão é estabelecida com a RMSP". Lima (2011), indica que a Região Metropolitana de Campinas é responsável por cerca de $12 \%$ de todas as viagens diárias de caminhão do Estado e que as principais cargas estão relacionadas com produtos das indústrias não alimentares, químicos e petroquímicos, minerais e alimentares

A circulação desses caminhões ocorre não apenas no interior da RMC mas em conexão com outras regiões metropolitanas e diversas áreas do estado. Essa circulação inclui trajetos por territórios de diversos municípios, ainda que as rodovias sejam de operação estadual ou federal. Segundo a EMPLASA (2018b), essa questão merece atenção, visto que com a demanda da circulação de cargas aumenta também a demanda por regras comuns entre os municípios para a circulação de cargas no território metropolitano. Esses acordos precisam ser efetivados entre os gestores da malha rodoviária nas suas diversas esferas, pública e privada.

Nas vias do Vetor 3, é perceptível que os caminhões circulam predominantemente nas rodovias e estradas, fora dos núcleos urbanos consolidados. Encontram-se, ainda, diversos tipos de caminhões, com funções que definem os locais por onde trafegam.

Os caminhões de grande porte, como os de transporte de produtos agrícolas, como a cana-de-açúcar, conhecidos como treminhões, mostrado na Figura 48, são encontrados circulando pelas rodovias e estradas, as vias macrometropolitanas e metropolitanas, com acesso às plantações
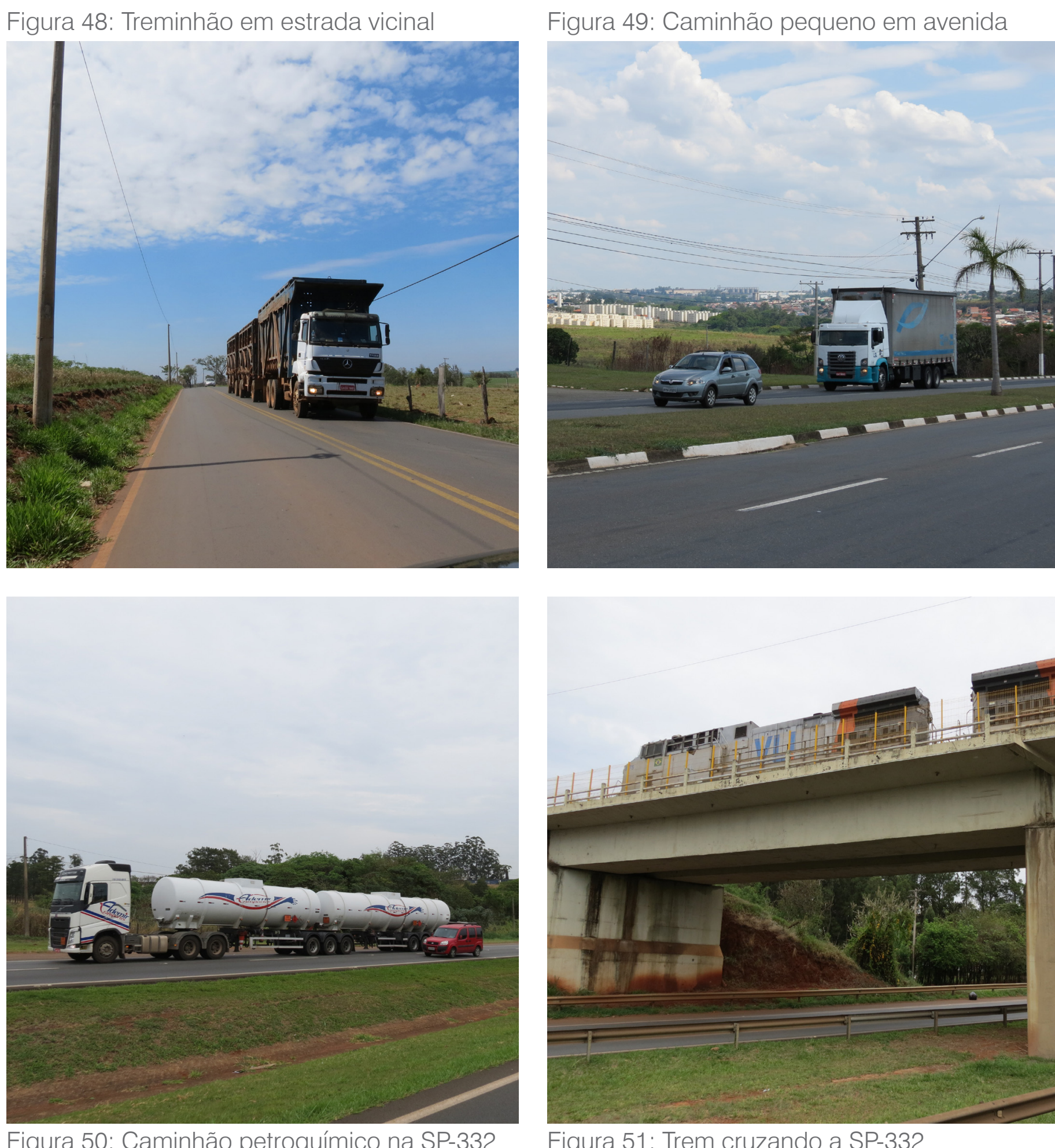

Figura 51: Trem cruzando a SP-332 
e às usinas de processamento. A condição das vias nem sempre é ideal para a circulação desse tipo de caminhão pela sua dimensão, como é o caso da Estrada Vicinal Pref. Orlando Kiosia, que liga Cosmópolis à Rodovia Prefeito Aziz Lian.

Os caminhões menores, com cargas diversas, podem ser vistos não apenas nas vias macrometropolitanas e metropolitanas, mas também nas vias metropolitanas secundárias, no interior dos núcleos urbanos. $\mathrm{Na}$ Figura 49, o caminhão trafega pela Avenida Pref. José Lozano Araújo, em Paulínia, via que dá acesso à Rodovia Anhanguera.

Já os caminhões de cargas química e petroquímica, mostrado na Figura 50, geralmente circulam pela Rodovia SP-332, dado que ali se concentram as indústrias produtoras e por essas vias é possível escoar os produtos para outras regiões. A SP-332 possui acesso direto à Rodovia Dom Pedro I, que distribui os fluxos todas as outras rodovias principais da RMC, como a Anhanguera e Bandeirantes.

\section{Trem}

Em relação às ferrovias, que tiveram grande importância na formação histórica da região de Campinas, atualmente só se realizam transporte de cargas. Segundo Lima (2011), são três as empresas que atuam na região de Campinas: Ferrovia Centro-Atlântica (FCA); Ferrovia Bandeirantes (FERROBAN) e MRS Logística. De modo geral, estas empresas estão ligadas aos setores siderúrgico, de mineração e agropecuário e contribuem fortemente para a integração do território brasileiro, ligando as regiões produtoras aos mercados externos.

O transporte de passageiros sobre trilhos é inexistente nesta área, atualmente. Existem planos para implantação de uma linha de trem de passageiros que deve conectar Campinas à São Paulo, com possível extensão à Americana, no entanto, a Companhia Paulista de Trens Metropolitanos (CPTM) não tem previsões para que esses planos saiam no papel.

De qualquer forma, para o Vetor 3, o trem de passageiros não deve ser uma realidade próxima. Ainda que tenha uma grande importância econômica na circulação de cargas pelo território, pode-se dizer que a ferrovia não tem expressão na paisagem nesta área. Os trilhos estão localizados em áreas afastadas das rodovias, cruzando-as em pontos específicos. Além disso, o ramal ferroviário tem fim no município de Paulínia, não se fazendo presente nos outros municípios do Vetor 3.

A Figura 51 mostra um dos dois cruzamentos dos trilhos de trem sobre a SP-332, nos quais ele pode ser visto, fazendo parte da paisagem local. Ainda que não tenha presença forte na paisagem, o trem tem função importante na circulação de cargas, principalmente pela área de logística existente próxima à REPLAN. 


\section{TRANSPORTE INDIVIDUAL MOTORIZADO}

\section{Automóvel}

Os automóveis são responsáveis pela maior parte das viagens da RMC, dado o sistema rodoviário eficiente existente na região, e sua predominância está em crescimento. Segundo a Pesquisa Origem-Destino de 2011, em 2003, 35,7\% das viagens em modo individual foram realizadas por automóvel, enquanto em 2011 foram 43,66\%, indicando que o aumento da mobilidade da região se deve especialmente às viagens nesse modal. No total, as viagens de automóvel representam $38,5 \%$, sendo o modal mais utilizado.

A pesquisa ainda mostra que a participação das viagens por transporte coletivo no total de viagens motorizadas e não motorizadas para as classes D e E é de 32,2\%, enquanto para as classes A e B é de 18,9\%. Isso mostra que a participação do modo individual nas viagens aumenta quanto maior a renda

Nas entrevistas realizadas para este trabalho, observou-se que mesmo as pessoas que usam ônibus diariamente para se deslocar na região como um todo, utilizam o automóvel como meio de transporte, principalmente nas atividades de final de semana, lazer e compras, que possuem destinos e horários menos rígidos.

A Pesquisa Origem-Destino de 2011 indica, também, que o modo individual é mais utilizado em quase todos os motivos de viagem (compras, saúde, lazer, assuntos pessoais, etc). No entanto, nas viagens motivadas por estudo e trabalho, o transporte coletivo se mostra mais presente. Nas viagens motivadas por trabalho, os índices são muito próximos, mas nas por motivo estudo, a diferença é maior. Isso se deve à idade da população que se move em idade escolar, além dos custos do transporte individual.

Os automóveis estão em todas as vias e áreas da RMC e do Vetor 3. A presença do automóvel é tamanha, que é possível ocorrer congestionamentos nas rodovias, como observado na Figura 52. Essa

Figura 52: Congestionamento na Rodovia SP-332
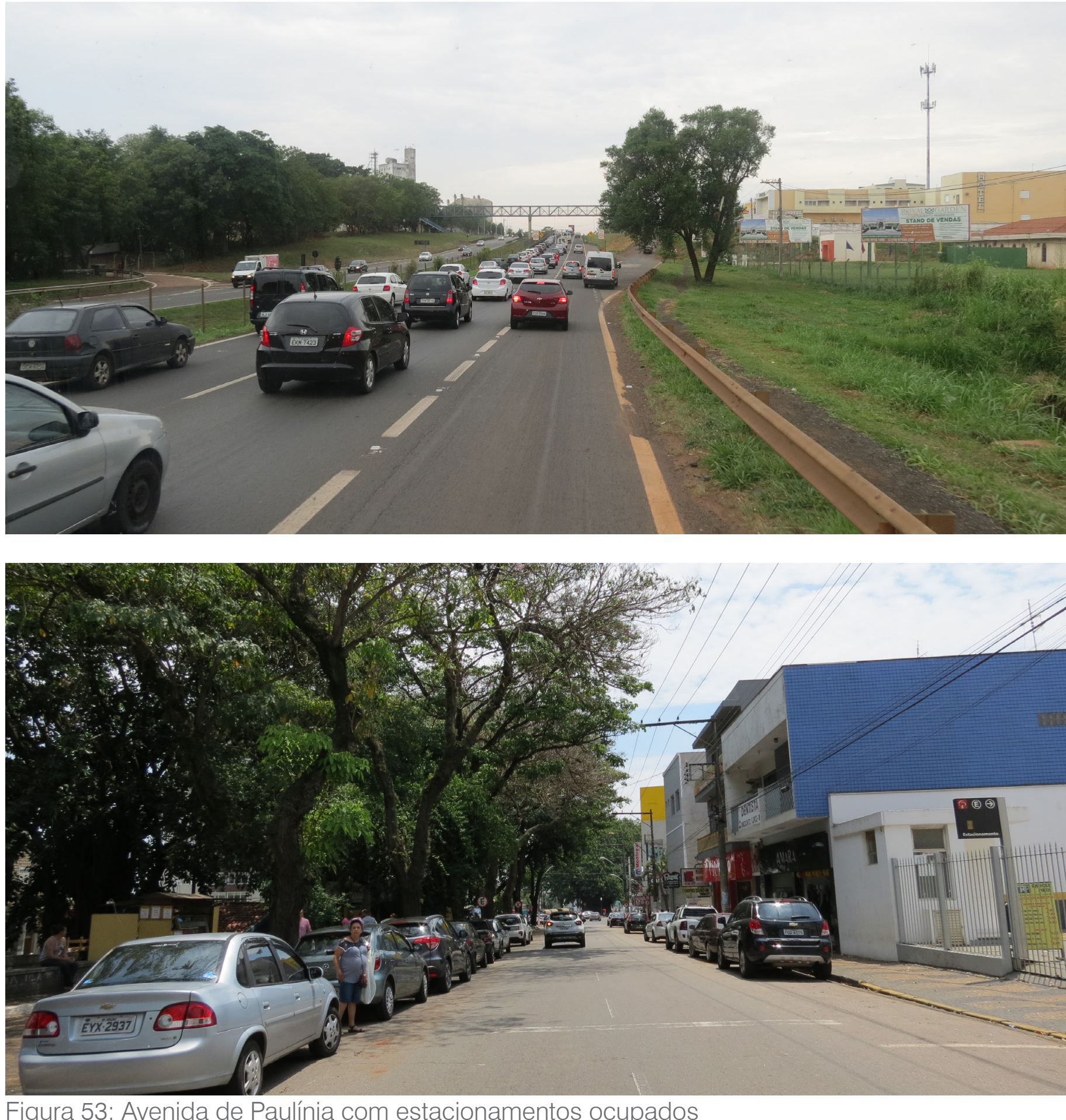
situação ocorreu na SP-332, em uma na segunda-feira, pela manhã próximo à cidade de Paulínia. O tráfego lento impacta não apenas os próprios automóveis, como os ônibus intermunicipais e demais modais.

Nos núcleos urbanos consolidados, os automóveis dominam a paisagem, ocupando as ruas e avenidas, com fluxo e com estacionamentos. Na Figura 53, por exemplo, é possível observar que todas as vagas de estacionamento estão ocupadas, em via metropolitana secundária do centro da cidade de Paulínia, com ocupação comercial de um lado e uma praça do outro. Além de ambos os lados estarem ocupados por automóveis estacionados, existe, do lado esquerdo da via, um estacionamento particular, que atende os comércios do entorno.

\section{Carona}

Fazem parte do modal automóvel as caronas. Elas ocorrem em toda a região, seja no interior das cidades, seja para deslocamentos mais longos, como, por exemplo, na ida para o trabalho nas indústrias localizadas em outros municípios. Nas entrevistas realizadas, a carona apareceu como um dos meios de transporte usados para os deslocamentos diários, assim como os sistemas de transporte por aplicativos.

Para os moradores das cidade além de Cosmópolis, que se deslocam diariamente em direção a Paulínia e Campinas, a carona é uma opção que facilita a circulação e reduz os custos de viagem, em relação ao automóve individual ou até mesmo o transporte coletivo metropolitano, principalmente devido aos custo de pedágio da Rodovia SP-332. Essa condição, atrelada à menor dependência dos horários e trajetos do transporte coletivo, faz com que seja um modal bastante utilizado.

Essa forma de deslocamento também é utilizada para acesso às áreas de dispersão urbana, afastadas dos núcleos urbanos. Na Figura 54, é possíve ver o desembarque de um caronista na SP-332, que é estudante do ensino médio em escola da cidade de Cosmópolis. Ele mora em bairro afastado do centro da cidade e pega carona com um colega, que mora em outro bairro, ainda mais afastado, para ir e voltar da escola, que fica localizada em bairro próximo, mas de difícil acesso a pé, sendo necessário cruzar a passarela e caminhar pelas margens da rodovia. Dada a insegurança do trajeto, a carona se mostra um meio mais viável neste trajeto cotidiano.

\section{Motocicletas}

Como outro modal de transporte privado, individual, a motocicleta aparece como responsável por 4,9\% das viagens, à frente do transporte por ônibus intermunicipal, segundo dados da Pesquisa Origem-Destino de 2011.

Observa-se que as motocicletas estão presentes em todas as áreas, desde os espaços intraurbanos até os metropolitanos, circulando em todas as vias da RMC. Na imagem, o motociclista trafega pela Rodovia SP-332, em viagem intermunicipal, entre Cosmópolis e Artur Nogueira.
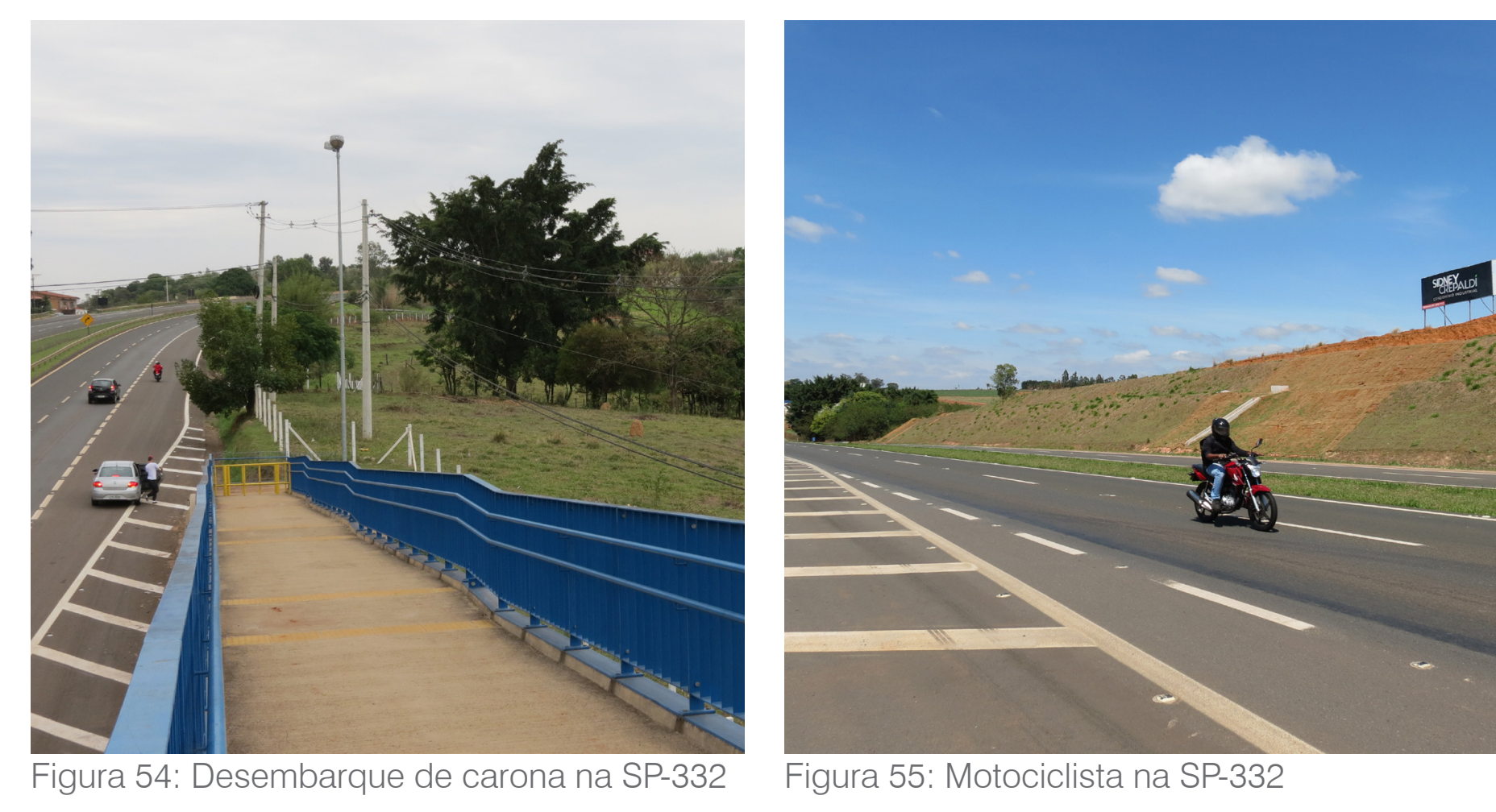


\subsubsection{OCUPAÇÃO}

Neste item, será apresentada a caracterização da ocupação do Vetor 3, com foco nas áreas lindeiras às vias de caráter metropolitano. Serão tratados de três grupos de uso principais: das ocupações residenciais; das ocupações por atividades econômicas; e das ocupações das áreas rurais

O grupo de ocupações residenciais é composto basicamente pelas áreas residenciais tradicionais, de loteamentos regulares, e pelos condomínios fechados ou loteamentos fechados. Em relação à ocupação das atividades econômicas, estão presentes no Vetor 3 as áreas comerciais e de serviços, os comércios informais, os condomínios empresariais, as indústrias e os equipamentos, principalmente os de cultura e ensino. Nas áreas rurais, serão abordadas as chácaras e sítios de moradia e veraneio os loteamentos irregulares que avançam sobre essas áreas, as áreas de produção agrícola familiar e as de produção agrícola comercial. 


\section{OCUPAÇÕES RESIDENCIAIS}

\section{Condomínios residenciais e loteamentos fechados}

Quando se trata do tema da ocupação das vias metropolitanas do Vetor 3, o que mais se destaca na paisagem são os condomínios residenciais ou loteamentos fechados, seja pela sua presença imponente, seja pela grande quantidade e extensão, ou, ainda, pela sua relação, mesmo que de negação, com o espaço público das vias.

De acordo com Pires (2007), os primeiros condomínios da região datam da década de 70 e surgiram no município de Campinas. São cinco os primeiros condomínios, sendo que um deles está localizado na estrada da Rhodia, via metropolitana que faz parte do Vetor 3, o Condomínio Residencial Rio das Pedras, com área de 505.189,00m² e 219 lotes.

Além dos condomínios, são observados loteamentos fechados, definidos como empreendimentos aprovados como loteamentos tradicionais e que, posteriormente, realizam o fechamento e o controle do acesso às áreas públicas, com exclusividade aos moradores e proprietários, o que thes garante similaridades urbanísticas com os condomínios (PIRES, 2007). Essa condição é questionável, juridicamente, no entanto tem sido muito praticada, ainda que sem autorizações do poder público. Ainda assim Campinas, por exemplo, possui legislação específica que autoriza este tipo de ocupação.

Segundo Pires (2007), nos anos 90, surgiram novas perspectivas de investimento imobiliário em Campinas, com a aprovação de duas leis, com objetivos específicos para a constituição de empreendimentos em formas urbanas até então irregulares. São elas: a Lei 8736/96, que regulamenta os loteamentos fechados, aprovada durante o processo de regulamentação do Alphaville, em Campinas; e a Lei 8853/96, que permite a criação de bolsões urbanos inseridos em área rural, aprovada em função da regularização de um loteamento de alto padrão localizado no Vetor da Rodovia Adhemar de Barros. A partir desta lei, passou a ser

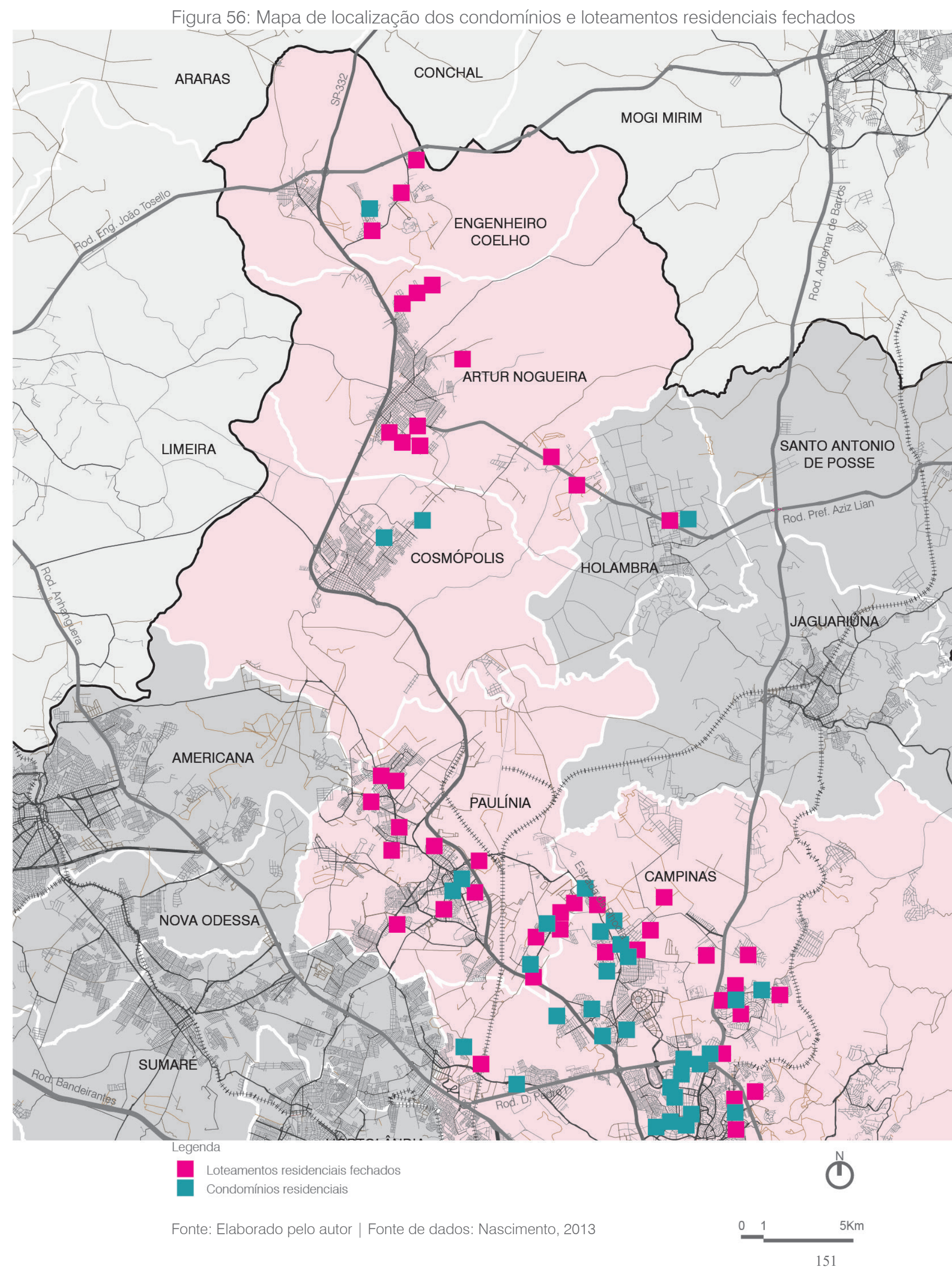


possivel o parcelamento de inúmeras fazendas localizadas na região norte de Campinas, incluindo o Vetor 3

A Figura 56 mostra a localização dos condomínios e loteamentos fechados no Vetor 3 e é possível notar que existe concentração próxima às vias de caráter metropolitano. Os condomínios encontram-se, em maior quantidade, nos municípios de Campinas e Paulínia, principalmente nos distritos de Barão Geraldo e Betel. Já os loteamentos fechados, estão em todos os municípios, com destaque para a grande quantidade em Artur Nogueira e Engenheiro Coelho, como forma de ocupação mais recente.

É importante destacar que a implantação desse tipo de ocupação, propicia a descontinuidade do tecido urbano, uma vez que a relação direta entre a área interna com as áreas externas aos muros ocorre pelas portarias, com acesso pontual. A Figura 57 mostra um condomínio recente da cidade de Paulínia que possui apenas um acesso em uma de suas extremidades, o que impede a continuidade com as vias que o delimitam. Além disso, o muro que o circunda impede, inclusive, a conexão com a Rodovia SP-332, uma vez que separa as vias internas da via macro metropolitana.

Em uma escala menor, nas relações com os espaços livres, os condomínios e loteamentos fechados são bastante peculiares. A situação da relação do condomínio Rio das Pedras com a via do entorno, a Estrada da Rhodia, por exemplo, revela a falta de integração entre os espaços e a desconsideração da circulação dos pedestres por esta área, como mostra a Figura 58. Além de não existir calçada, o espaço que seria destinado a ela é tomado por taludes, próximos ao muro alto.

Dessa mesma forma, os loteamentos fechados típicos, localizados nas regiões de Betel e Barão Geraldo, possuem configuração de muros extensos, altos e com proteções, ausência de pavimentação das calçadas e infraestrutura viária em boas condições, quando se trata do fluxo de automóveis, conforme mostrado na Figura 59. A presença de vários loteamentos fechados próximos um dos outros transforma a via em uma espécie de corredor confinado, no qual os pedestres não são bem vindos.
Figura 57: Foto aérea de condomínio em Paulínia

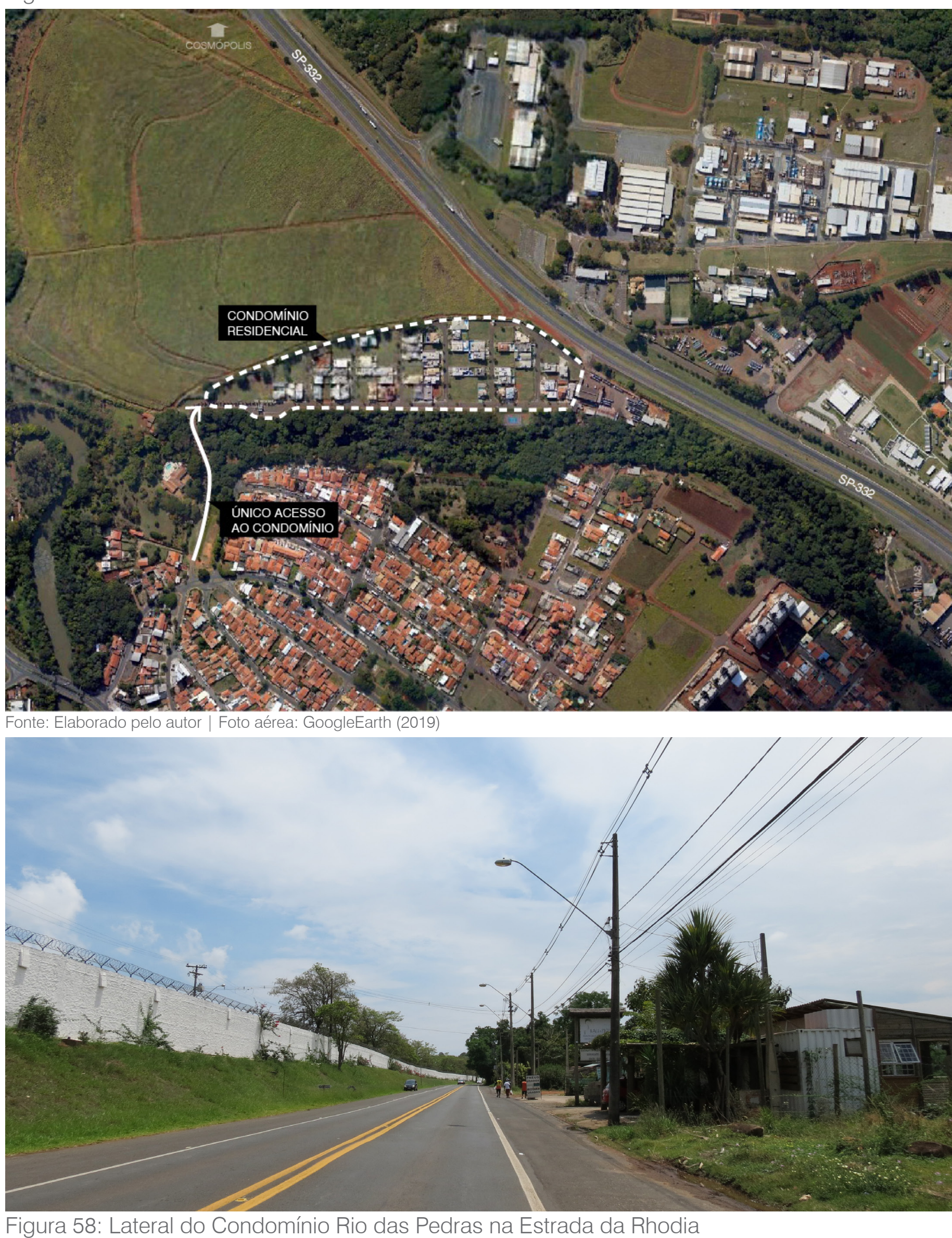


Além de as áreas externas não serem de interesse dos condomínios, já que mantém todas as suas atividades em seu interior e a maioria dos seus moradores são usuários dos meios de transporte motorizados individuais, as soluções para as calçadas do seu entorno, geralmente são empregadas de forma absurda, como pode ser visto na Figura 60. Neste caso, o corte no terreno do condomínio, para implantação do muro e das residências teve grande influência nas calçadas, obrigando a sua elevação em relação à rua, criando uma espécie de passarela.

Mas não são apenas nas rodovias e estradas que estão localizados os condomínios e loteamentos fechados. Em Paulínia, por exemplo, é possíve observar a recente ocupação de áreas de vazios urbanos nas avenidas classificadas como vias metropolitanas secundárias, principalmente as que possuem acesso à Rodovia Anhanguera, como mostrado na Figura 61. Isso mostra a tendência de ocupação das cidades do Vetor 3

É interessante ressaltar, ainda, que todos os loteamentos fechados desta região são de alto padrão. E essa condição chama bastante a atenção quando são implantados em municípios de pequeno porte, como é o caso de Engenheiro Coelho, como mostrado na Figura 62. A implantação de condomínios, nos moldes dos implantados em Campinas, que têm como objetivo a fuga dos centros urbanos e a busca por um cenário de vida no campo (porém com proximidade das dinâmicas globais e completamente seguros), não faz sentido no contexto da cidade pequena.

Ainda assim, é clara a segregação espacial e social que estes empreendimentos significam, também nestas áreas. No caso de Engenheiro Coelho, por exemplo, os condomínios estão localizados em área completamente separada do núcleo urbano consolidado, no qual se concentra a população de baixa renda, e possui acesso específico, por via transversal à Rodovia SP-332. Estão próximos ao campus da universidade UNASP, que é um dos principais fatores de atração deste tipo de ocupação

Esses empreendimentos evidenciam que os condomínios não pretendem ter qualquer relação com as cidades ou municípios em que são implantados,

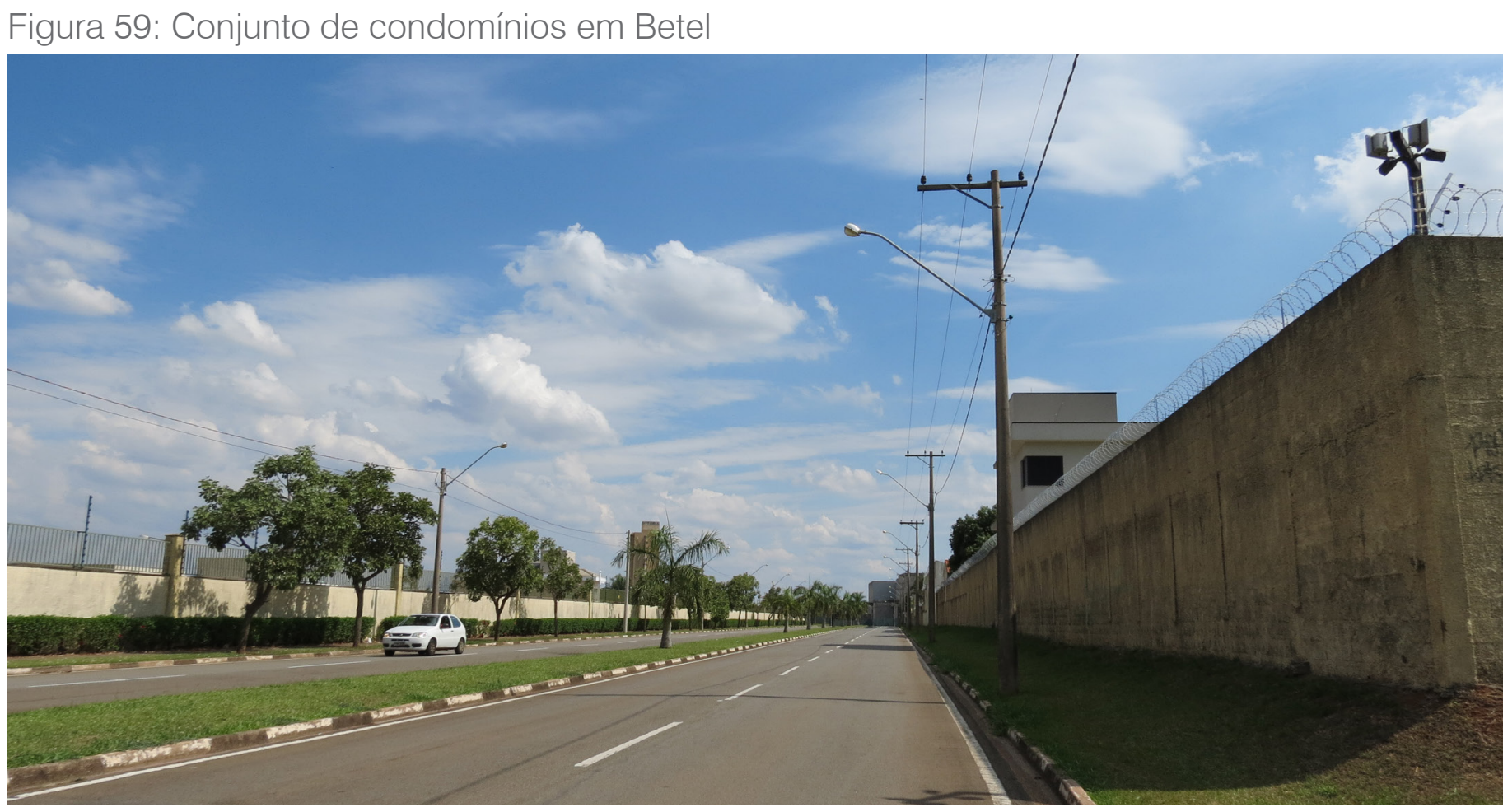

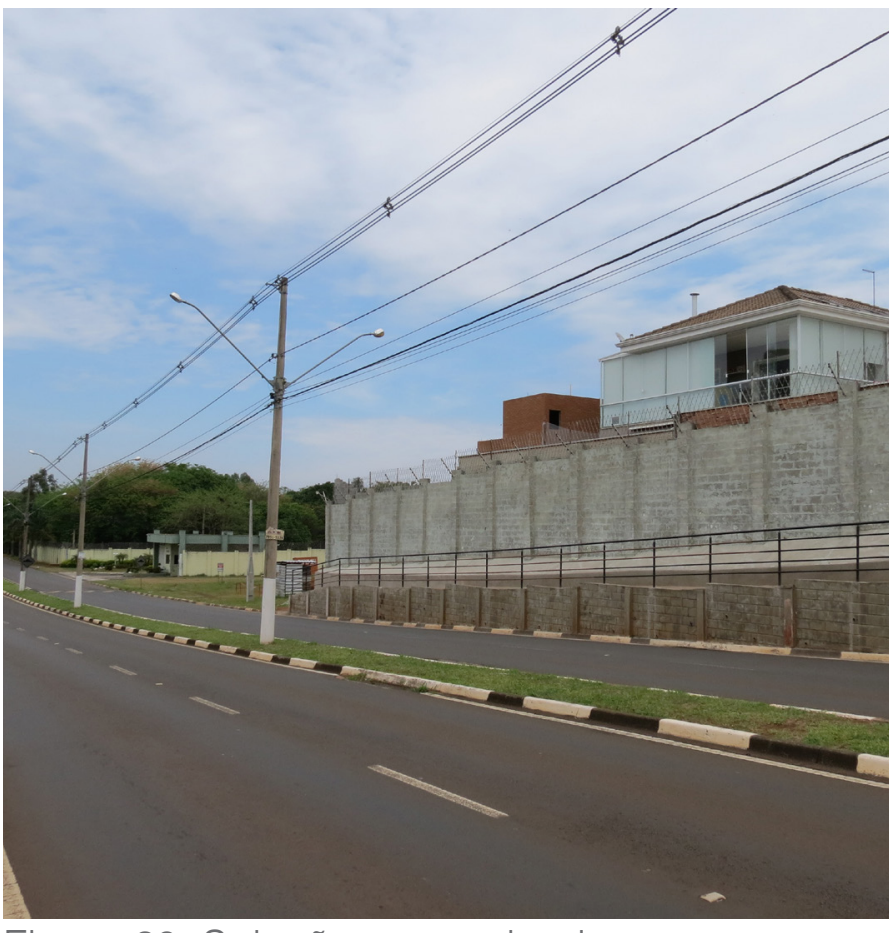

Figura 60: Solução para calçadas

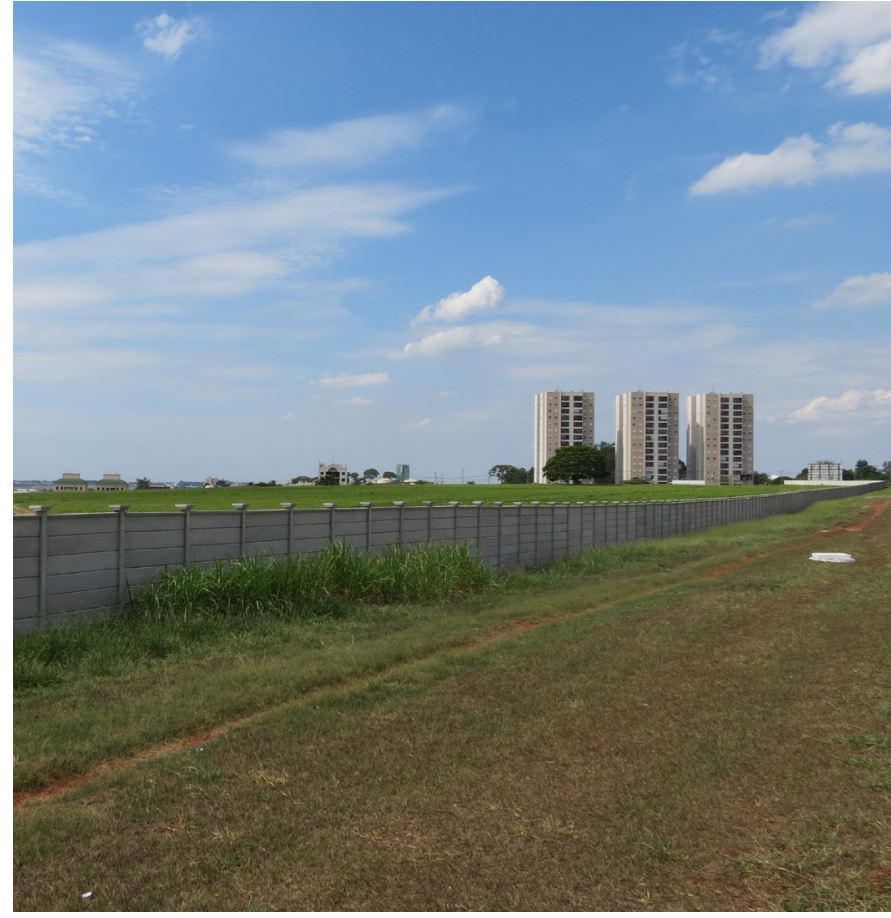

Figura 61: Condomínio em área urbana 
No caso de Cosmópolis, ainda que pareça não haver um grande atrativo para esse tipo de ocupação, até mesmo porque os investimentos em infraestrutura são bem menores que os de Engenheiro Coelho, estão em processo de implantação alguns loteamentos fechados, mostrados na Figura 63, localizados principalmente às margens da Estrada Pref. Orlando Kiosia, que interliga a cidade à Holambra, classificada como via metropolitana. É possível observar que, ainda que esse padrão de ocupação não seja um reflexo das dinâmicas da própria cidade, existe uma inspiração no modo de vida metropolitano, pautado pelas relações com a cidade sede.

A busca pelos condomínios nestas cidades é motivada, basicamente, pela necessidade de status social, uma vez que não há vantagens na localização desses empreendimentos, como acontece com os condomínios próximos às rodovias que dão acesso direto ao sistema viário composto por rodovias de importância regional.

Assim, ainda que os loteamentos fechados estejam inseridos em cenário bucólico, nas cidades pequenas, mas longe das principais vias regionais apresentam configuração parecida com os condomínios de Campinas. No caso de Artur Nogueira, por exemplo, como mostrado na Figura 64 o condomínio não possui acesso direto à rodovia, mas possui presença marcante na paisagem, pela extensão dos seus muros e grandes construções residenciais, separadas do espaço urbano.

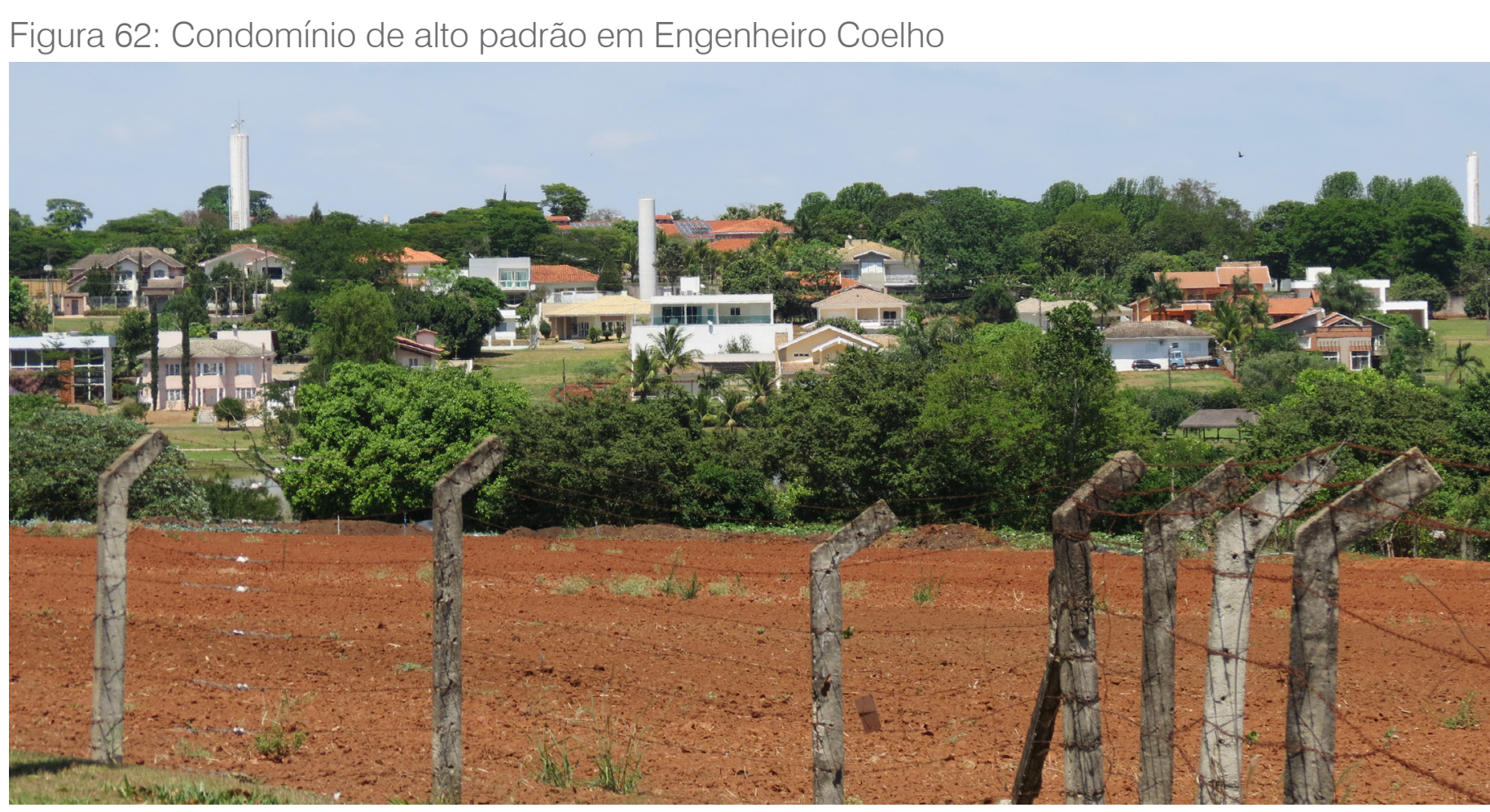

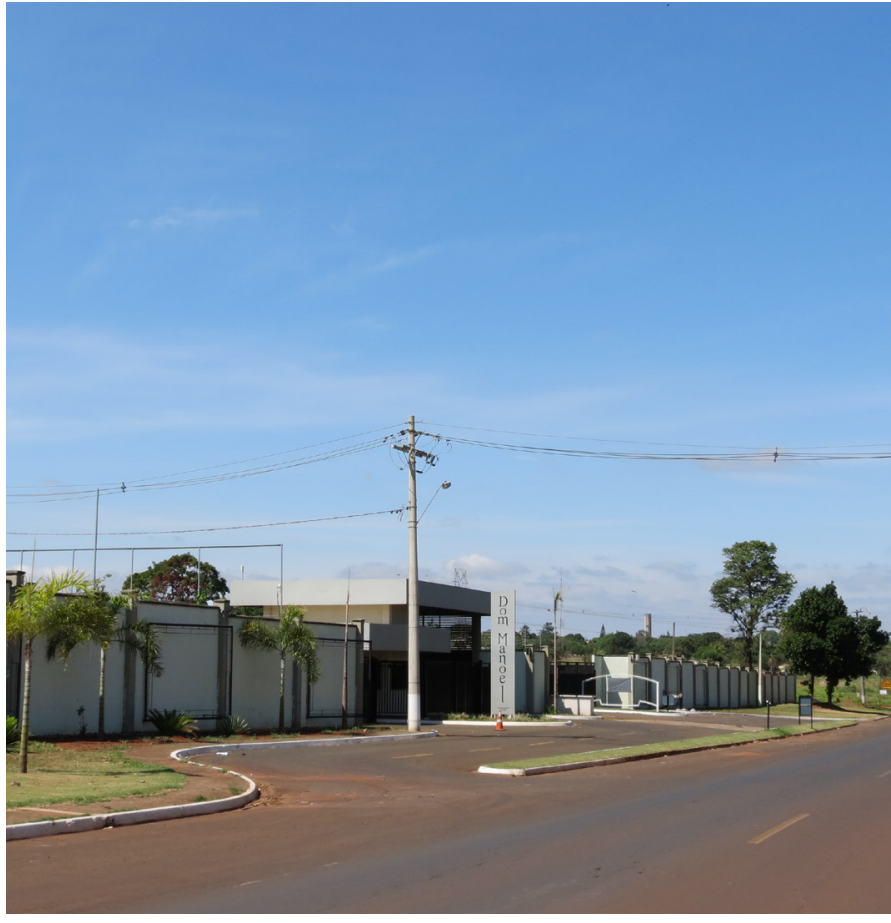

Figura 63: Condomínio em Cosmópolis

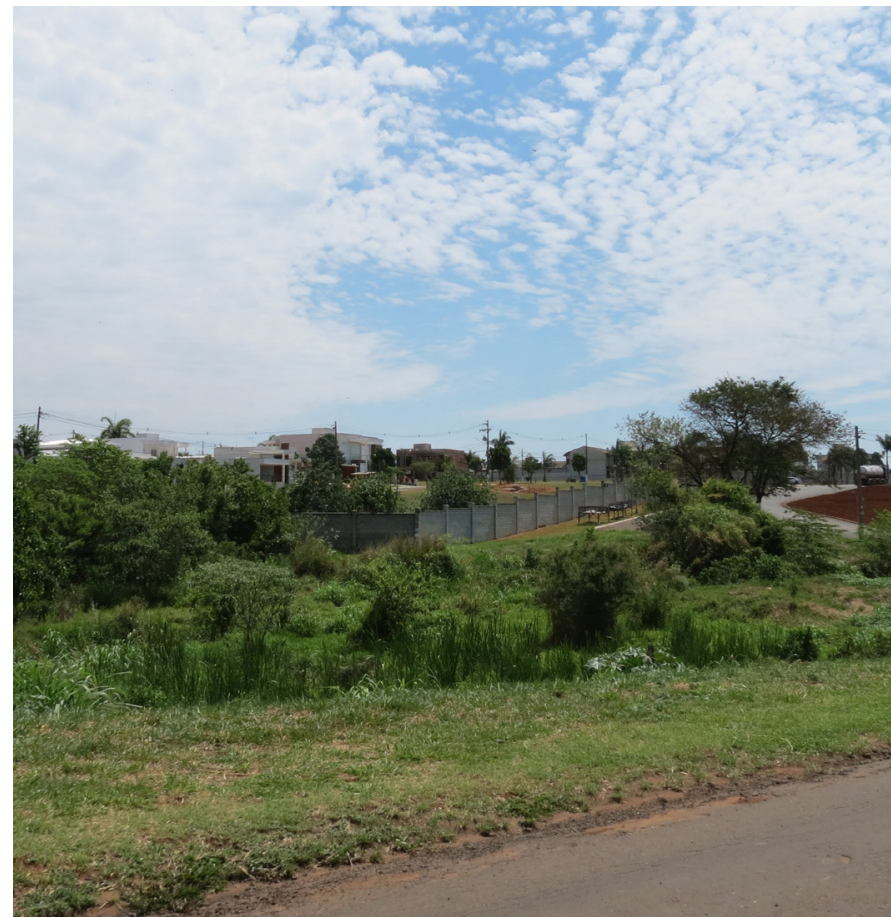

Figura 64: Condomínio em Artur Nogueira 


\section{ÁREAS RESIDENCIAIS}

Além dos condomínios e loteamentos fechados, é preciso considerar as áreas residenciais, os loteamentos convencionais que ocupam as áreas metropolitanas em estudo. A mancha urbana dispersa é a principal característica da ocupação residencial nas vias de caráter metropolitano. Em muitos casos, é através delas que a dispersão do território ocorre, uma vez que esses são os principais eixos de expansão da mancha urbana das cidades do Vetor 3. Essa condição pode ser observada na Figura 65, que mostra a ocupação residencial, em Paulínia, nas margens da estrada que liga esta cidade à Americana, sendo um importante eixo de desenvolvimento

A Figura 66 mostra a localização das áreas residenciais no Vetor 3 e é possível observar que, Paulínia e Campinas possuem muitas áreas urbanizadas fora do núcleo urbano consolidado e mancha urbana bastante fragmentada, o que inclui destacar a existência dos distritos de Betel e Barão Geraldo, pertencentes às duas cidades, respectivamente. Estes distritos já estão distantes dos centros das cidades e suas ocupações internas também ocorrem de forma dispersa.

Figura 65: Crescimento da ocupação residencial nas vias metropolitanas

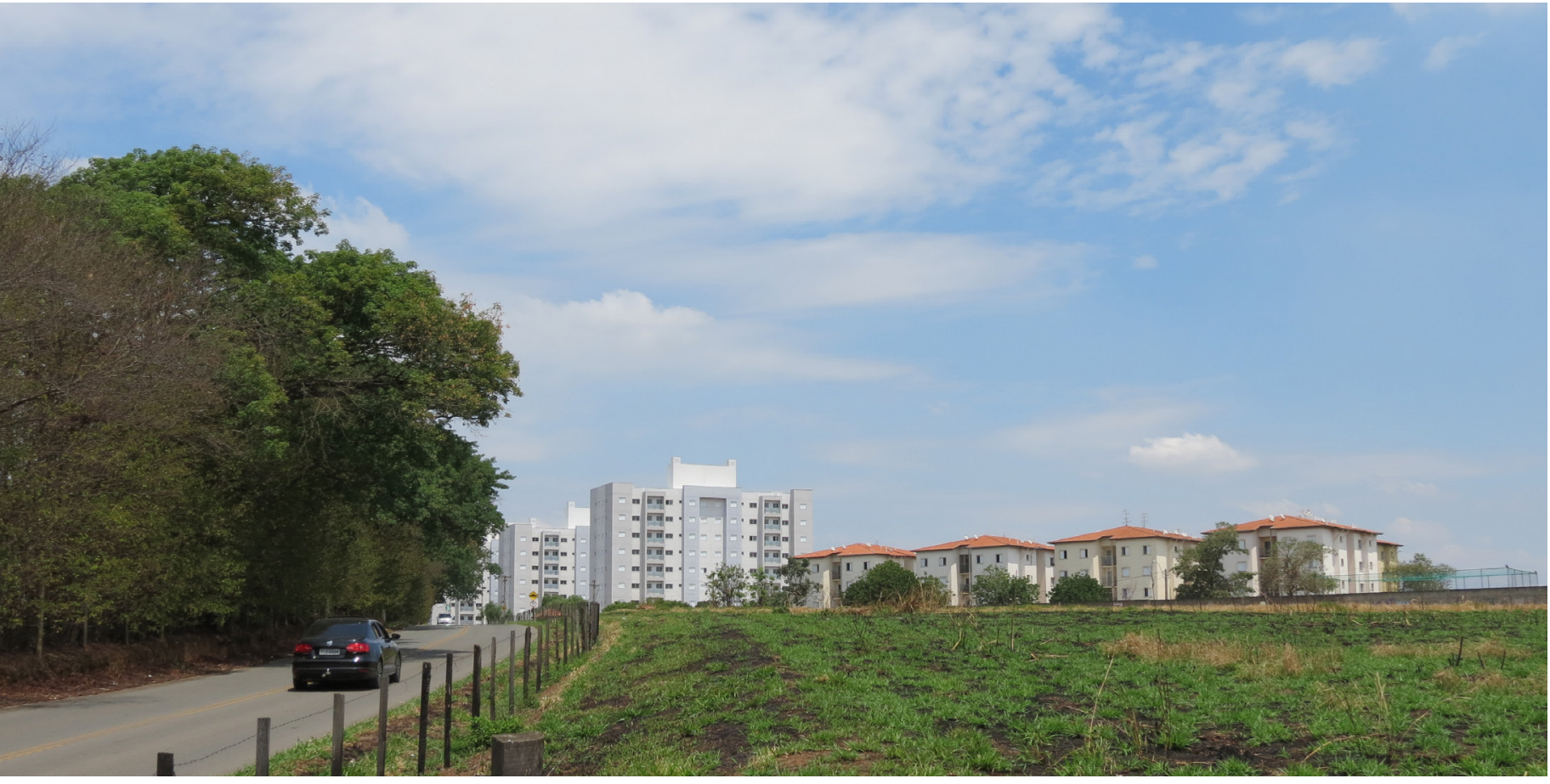

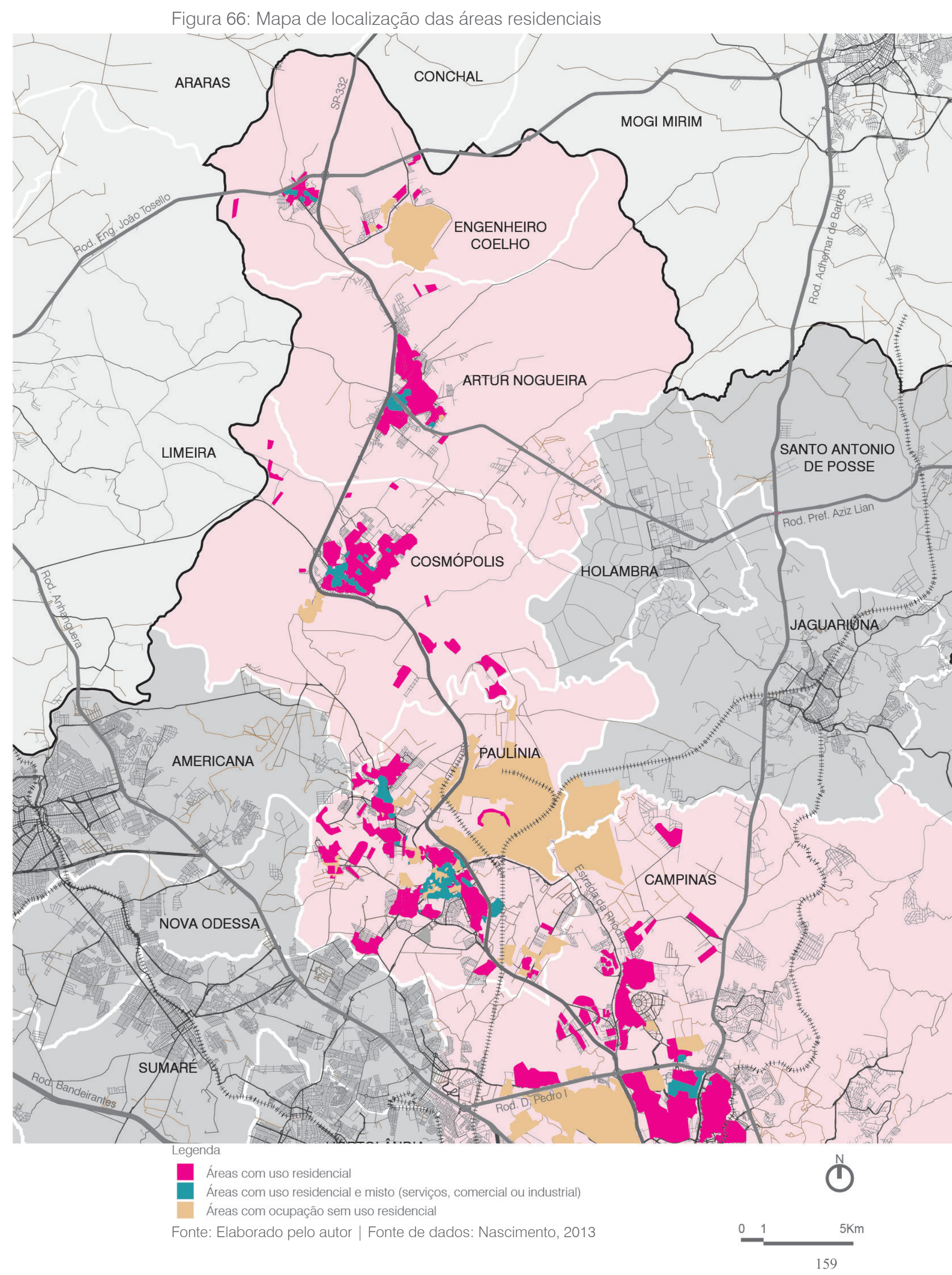


Já nas cidades menores, Cosmópolis, Artur Nogueira e Engenheiro Coelho, as áreas residenciais estão mais concentradas nos núcleos, ainda que existam pequenas manchas espalhadas pelo território, principalmente nos eixos das vias metropolitanas.

Na foto aérea, Figura 67, é possível observar que, em Cosmópolis, por exemplo, a SP-332 separa dois bairros de ocupação recente, ligados por meio uma passarela. Esse tipo de situação ocorre nas outras cidades menores e as formas de conexão com as outras áreas urbanas geralmente são precárias ou insuficientes. Essa condição pode ser observada na Figura 68, que mostra a ocupação residencial de Artur Nogueira, separada pela Rodovia SP-332, com acesso por apenas uma passarela. A presença de uma indústria têxtil tradicional da cidade é um dos fatores que impulsiona a ocupação desta área.

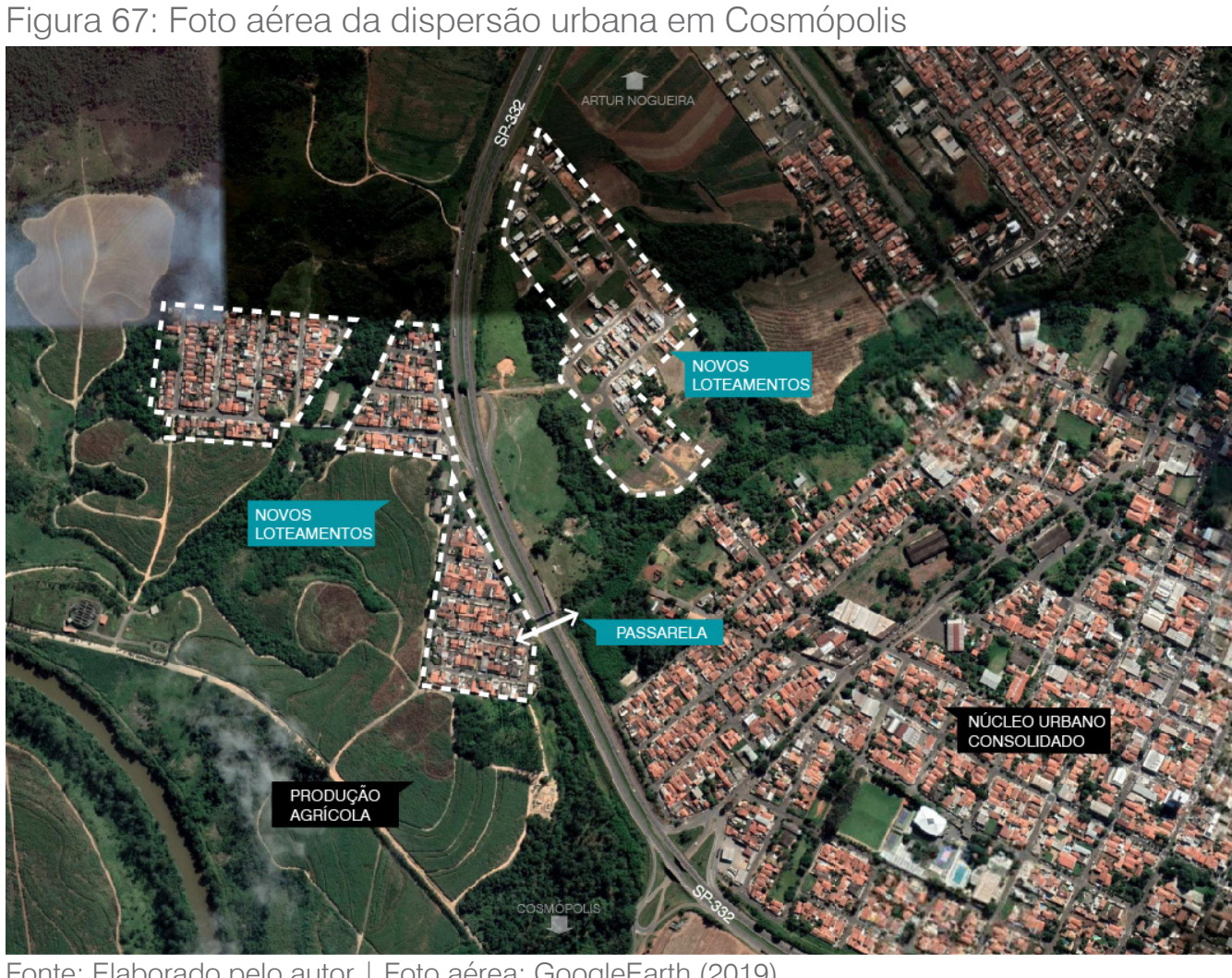

Figura 68: Loteamento residencial em área dispersa em Artur Nogueira
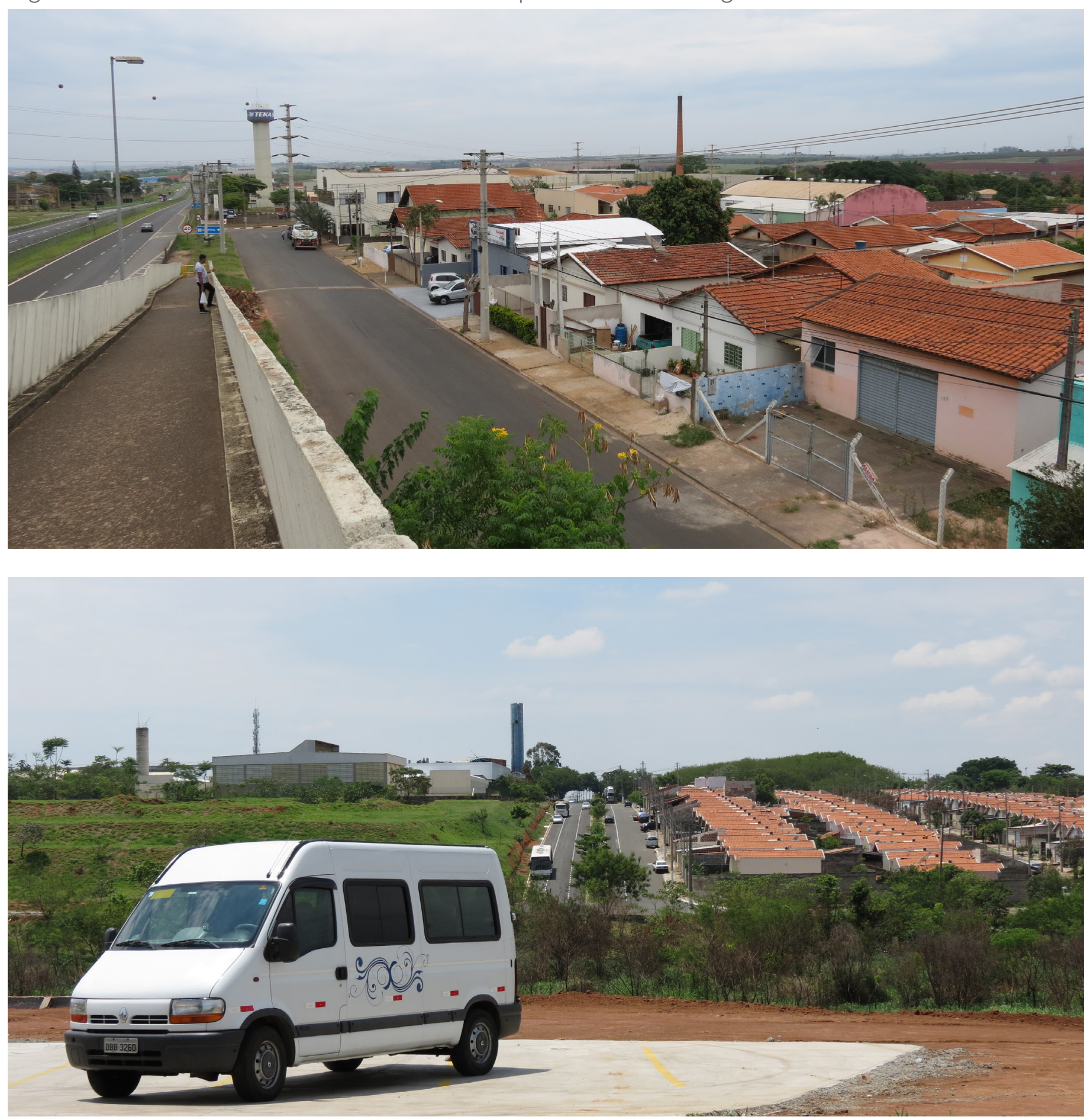

Figura 69: Loteamento residencial em Paulínia 
É importante destacar, ainda, que as áreas de expansão dessas cidades estão atreladas às definições do perímetro urbano, cuja ampliação incentiva a ocupação de novas áreas. De acordo com Nascimento (2013), Paulínia apresenta grandes áreas desocupadas com potencial de urbanização nas periferias das manchas urbanas consolidadas. Enquanto isso, Artur Nogueira e Cosmópolis possuem maior correspondência entre os tamanhos das áreas urbanizadas e dos perímetros urbanos em vigor.

Na Figura 69, por exemplo, é possível observar um conjunto habitacional na cidade de Paulínia, próximo a indústrias e grandes vazios urbanos, em área afastada do núcleo urbano consolidado, inseridos próximos a uma via metropolitana. Já a Figura 70 mostra a ocupação residencial em Cosmópolis, com o núcleo urbano consolidado se aproximando da Rodovia SP-332, separados por um canteiro arborizado, uma cerca e uma rua, pertencente ao sistema viário municipal, sem acesso à rodovia, que acontece apenas em pontos específicos.

A separação entre área residencial e rodovia, como ocorre em Cosmópolis, pode acontecer de formas estranhas, como é o caso de Engenheiro Coelho, conforme mostrado na Figura 71. A divisão entre a área residencial, que não é um condomínio ou loteamento fechado, acontece por um muro que percorre toda a extensão da ocupação, localizada do lado oposto do núcleo urbano consolidado, de frente para a Rodovia Engenheiro João Tosello

Mas a dispersão das ocupações residenciais no território do Vetor 3 não é exclusividade dos empreendimentos horizontais. Em Paulínia, é possível observar que as áreas afastadas do núcleo estão recebendo empreendimentos verticais, que podem ser visualizados a partir da Rodovia SP-332, fazendo parte da sua paisagem, como pode ser observado na Figura 72. Já na Figura 73, é possível perceber que as torres dos residenciais verticais não só fazem parte da paisagem, como estão sendo implantadas cada vez mais próximas das rodovias, ainda que sua relação se resuma aos muros que as cercam

Figura 70: Ocupação residencial em Cosmópolis Figura 72: Relação de residencial com rodovia
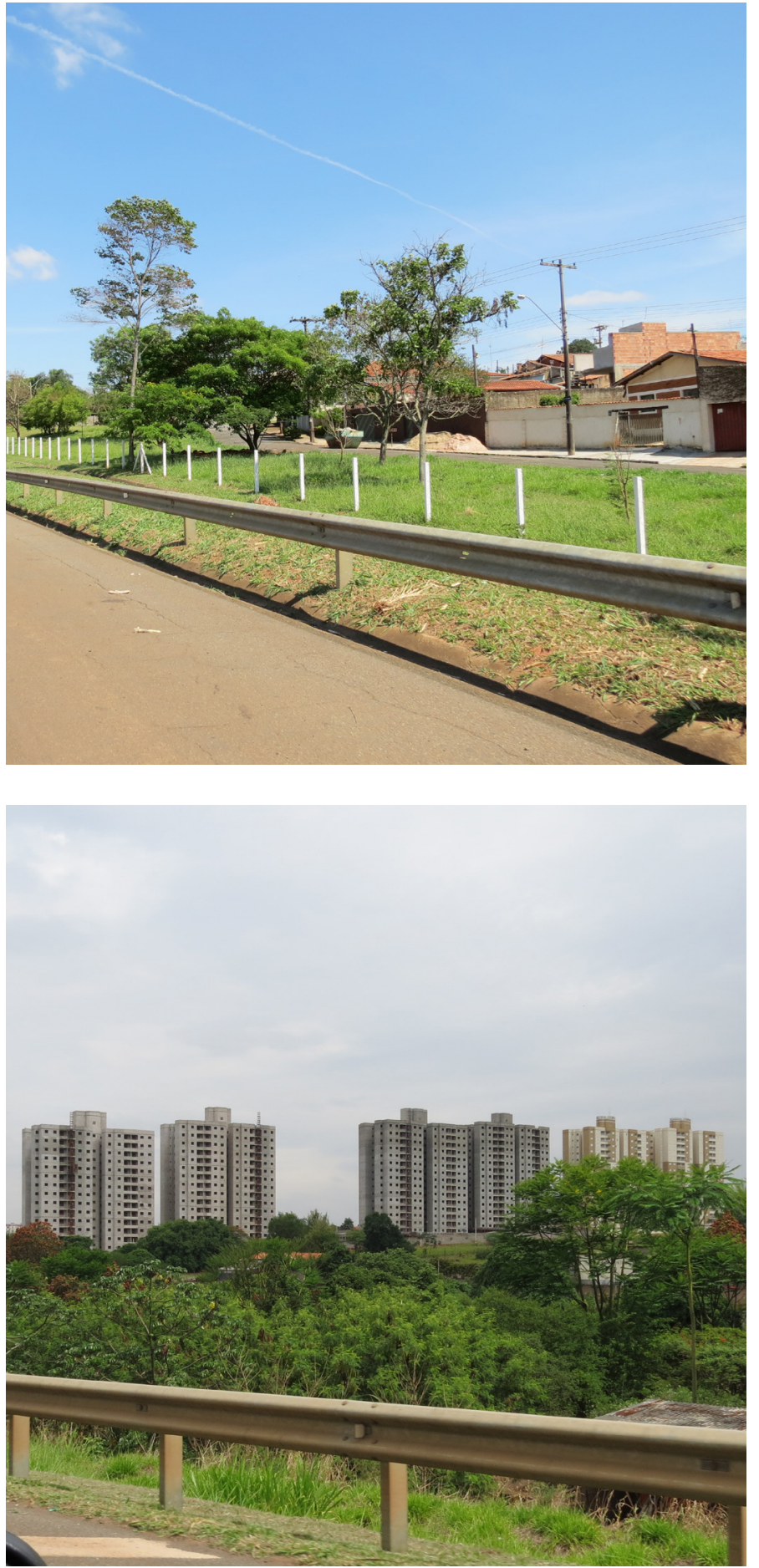

Figura 71: Verticalização em Paulínia
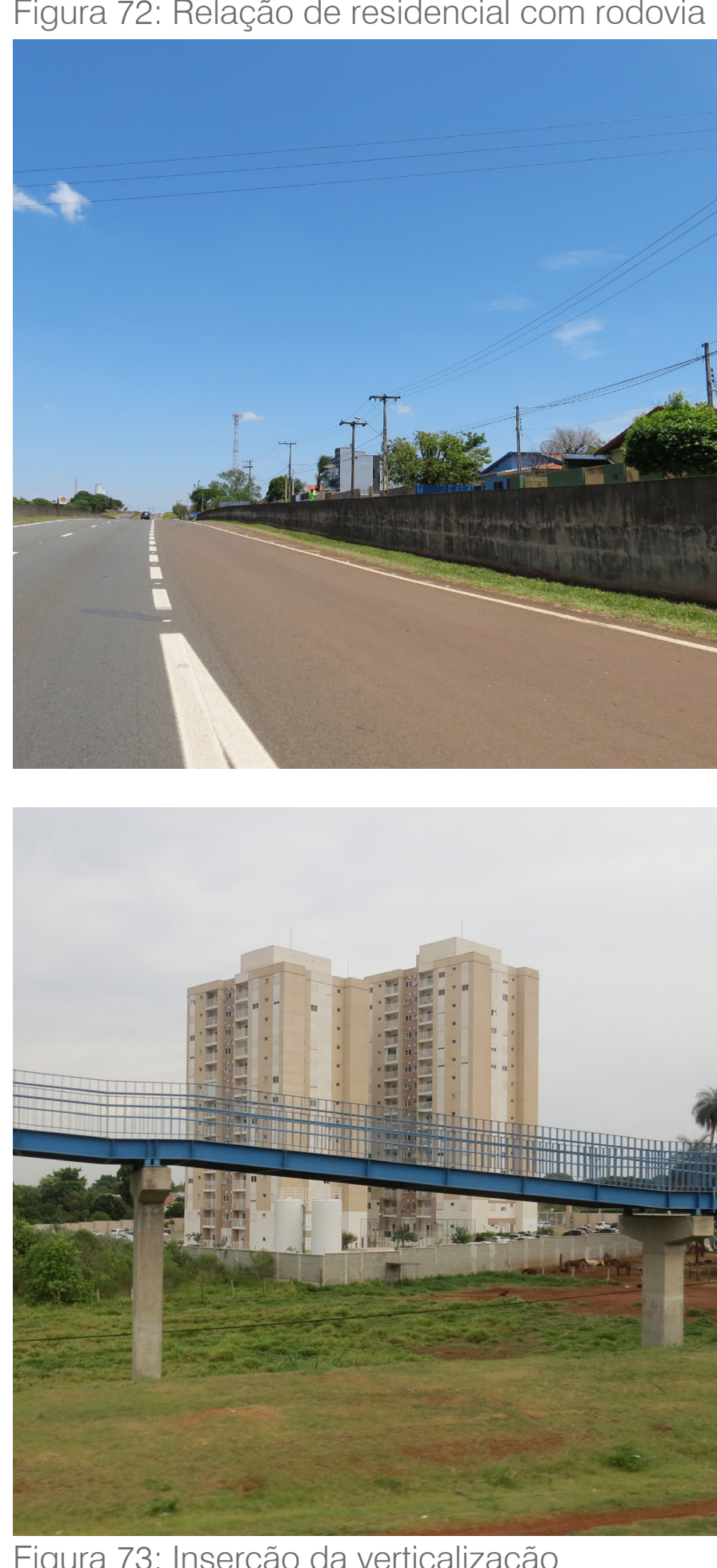

Figura 73: Inserção da verticalização 


\section{OCUPAÇÃO DAS ATIVIDADES ECONÔMICAS}

\section{Áreas comerciais e mistas}

Durante a visita a campo, foi possível perceber que os comércios e serviços que estão próximos às vias metropolitanas se relacionam diretamente às suas dinâmicas, na maior parte das vezes. Na Figura 74, estão representadas todas as áreas de atividades comerciais e de prestação de serviços do vetor. O que é possível perceber é a concentração dessas atividades nos núcleos urbanos e, em Paulínia, próximas à estrada de acesso à Americana, demonstrando que este é um importante eixo de crescimento da cidade.

As principais atividades reconhecidas no local foram as oficinas mecânicas e borracharias localizadas próximas à área industrial de Paulínia. Elas atendem a manutenção dos caminhões que passam em grande quantidade por ali, como mostra a Figura 75.

Um exemplo dos serviços que ocupam as áreas lindeiras da Rodovia SP332 e que está em posição estratégica, é o pátio de recolha e guarda de veículos, mostrado na Figura 76, na cidade de Cosmópolis, que recebe veículos apreendidos das cidades do entorno imediato, além de Campinas Indaiatuba, Valinhos e Vinhedo.

No entanto, não existem apenas comércios e serviços específicos na rodovia, com função de atendimento direto às dinâmicas das próprias rodovias. A Figura 77 mostra, por exemplo, uma loja de piscinas, localizada na SP-332, entre Cosmópolis e Artur Nogueira. Apesar de se utilizar da rodovia como principal via de circulação dos seus produtos de grande porte, não tem relação com as outras atividades do entorno. Essa mesma relação acontece com os motéis, com acessos diretos à rodovia, como mostrado na Figura 78, em área próxima do distrito de Barão Geraldo e com imagem marcante na paisagem. Foi observado, ainda, a presença de motéis na Rodovia Prefeito Aziz Lian, como mostrado na Figura 79, com menor destaque na paisagem da via.

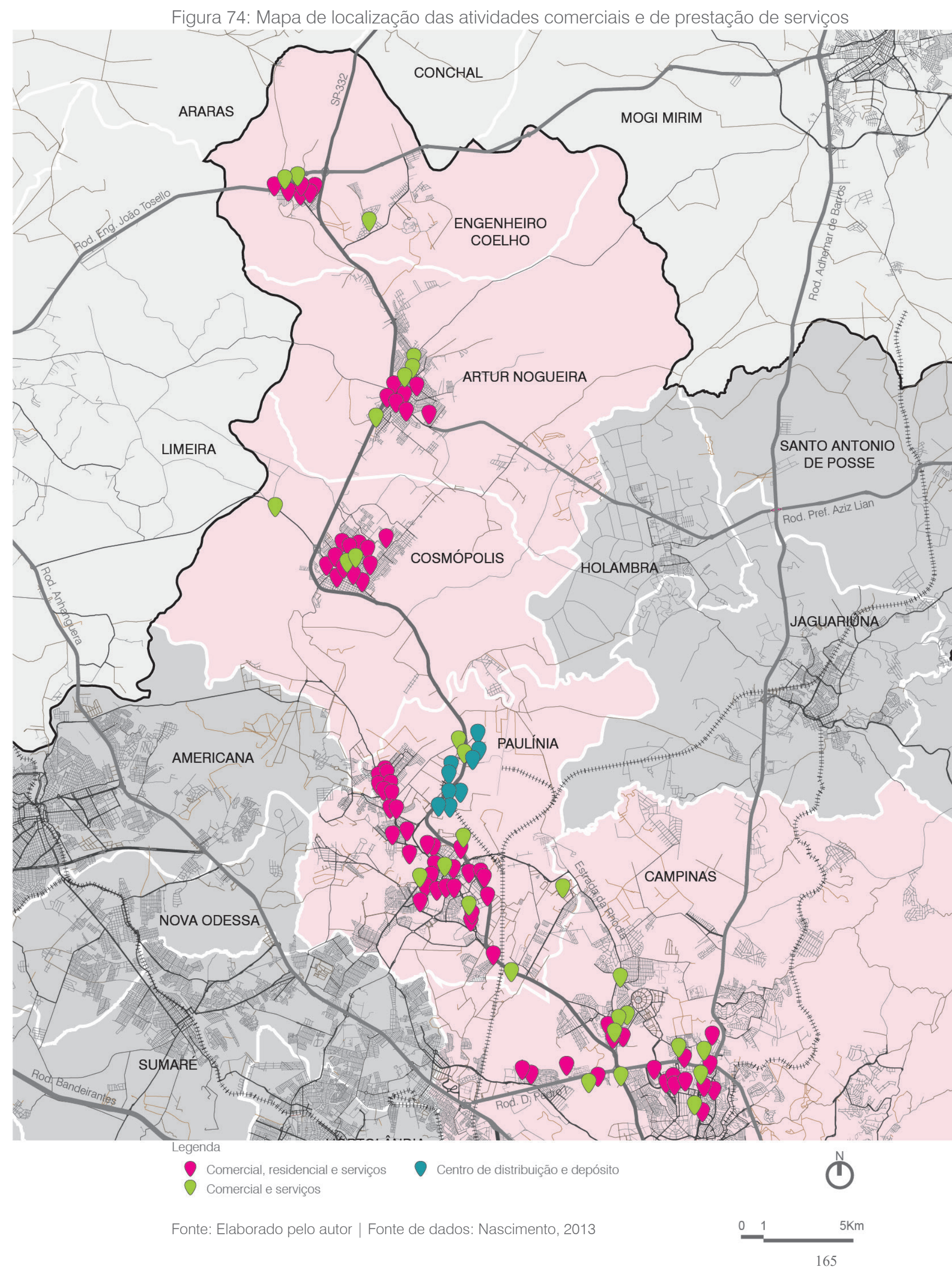


Nas vias metropolitanas e metropolitanas secundárias foram observados estabelecimentos comerciais menores, de interesse local, como é o caso do mercado e da drogaria na estrada da Rhodia, Figura 80, cujo público principal são os moradores dos condomínios da região. Nessa mesma estrada, são encontrados outros comércios menores, muitas vezes informais, como lojas de materiais de construção, que ocupam áreas livres e espaços vazios entre os condomínios, como mostrado na Figura 81, ou bancas de frutas, como na Figura 82, ou ainda um restaurante montado às margens da Estrada da Rhodia, na Figura 83.

Às margens das rodovias também foram identificados comércios que atendem à população que circula pelas áreas lindeiras e pelos núcleos de ocupação dispersa. A Figura 84 mostra um bar localizado na Rodovia Prefeito Aziz Lian, inserido em área de urbanização dispersa, atendendo principalmente a população daquele local. Na marginal da Rodovia SP-332, uma banca de pastel serve aos trabalhadores das indústrias e empresas daquela área e tem localização estratégica, próxima ao ponto de ônibus e da passarela de travessia da rodovia, conforme mostra a Figura 85.
Figura 75: Borracharias na SP-332
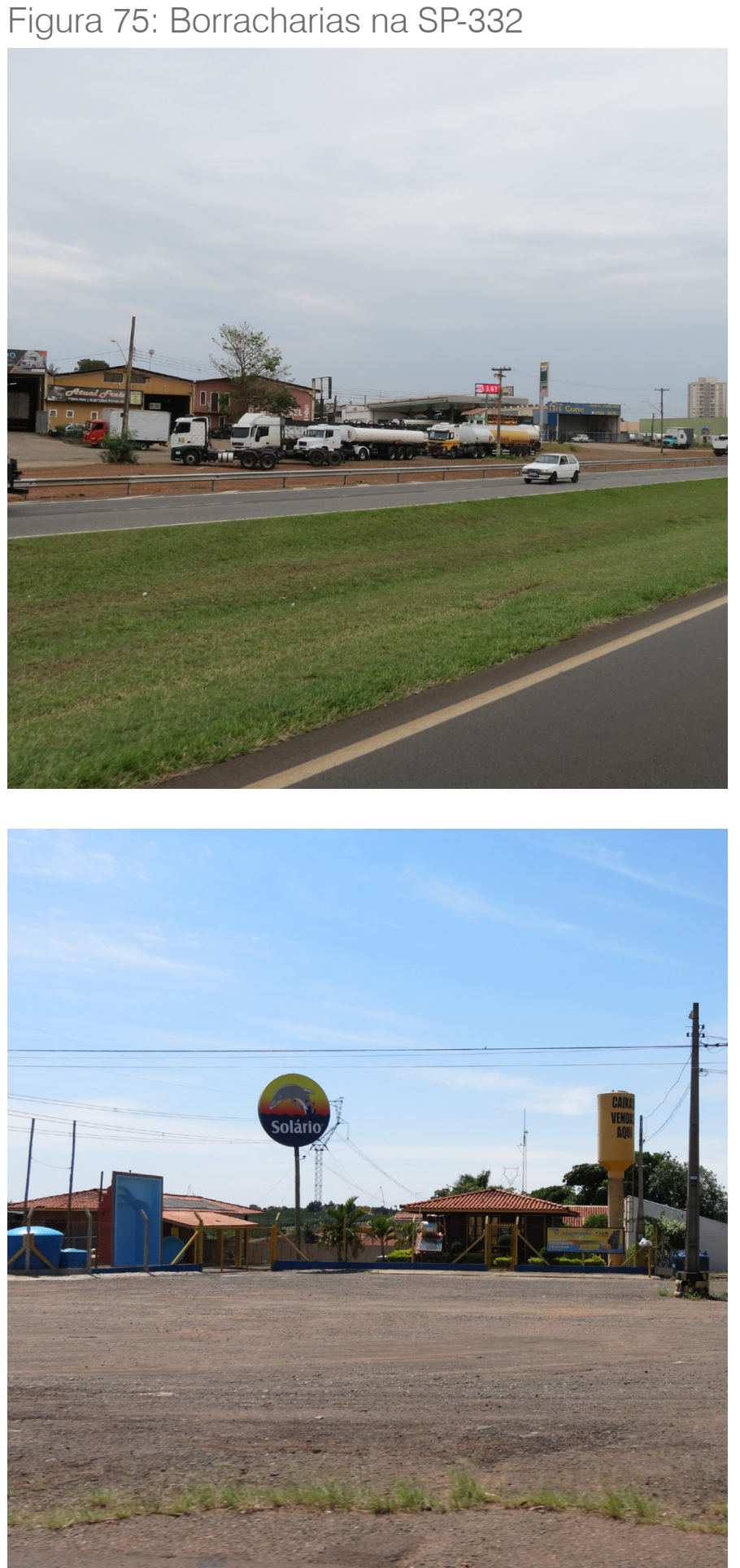

Figura 76: Loja de piscinas na SP-332
Figura 77: Pátio de recolha de veículos
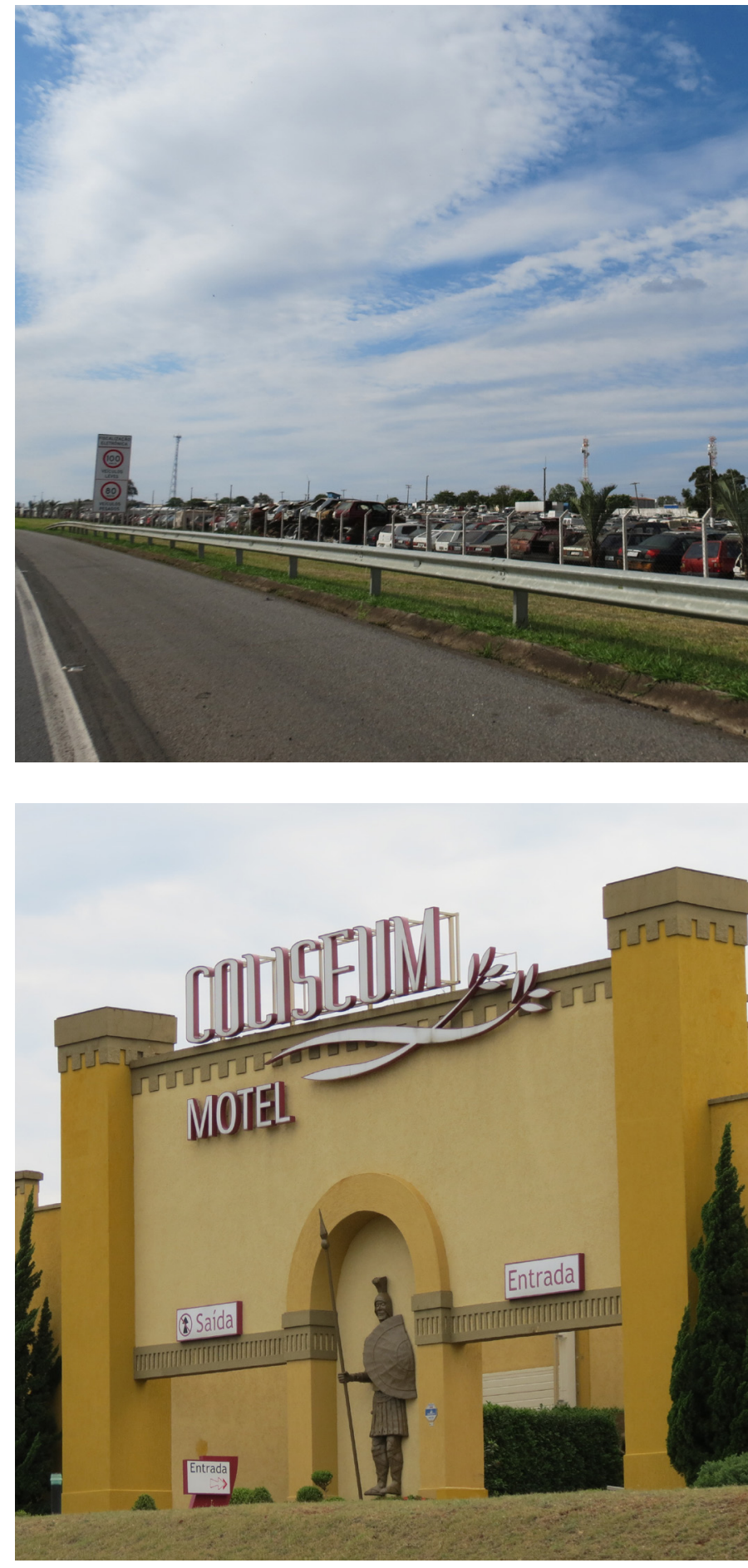

Figura 78: Motel em Barão Geraldo 

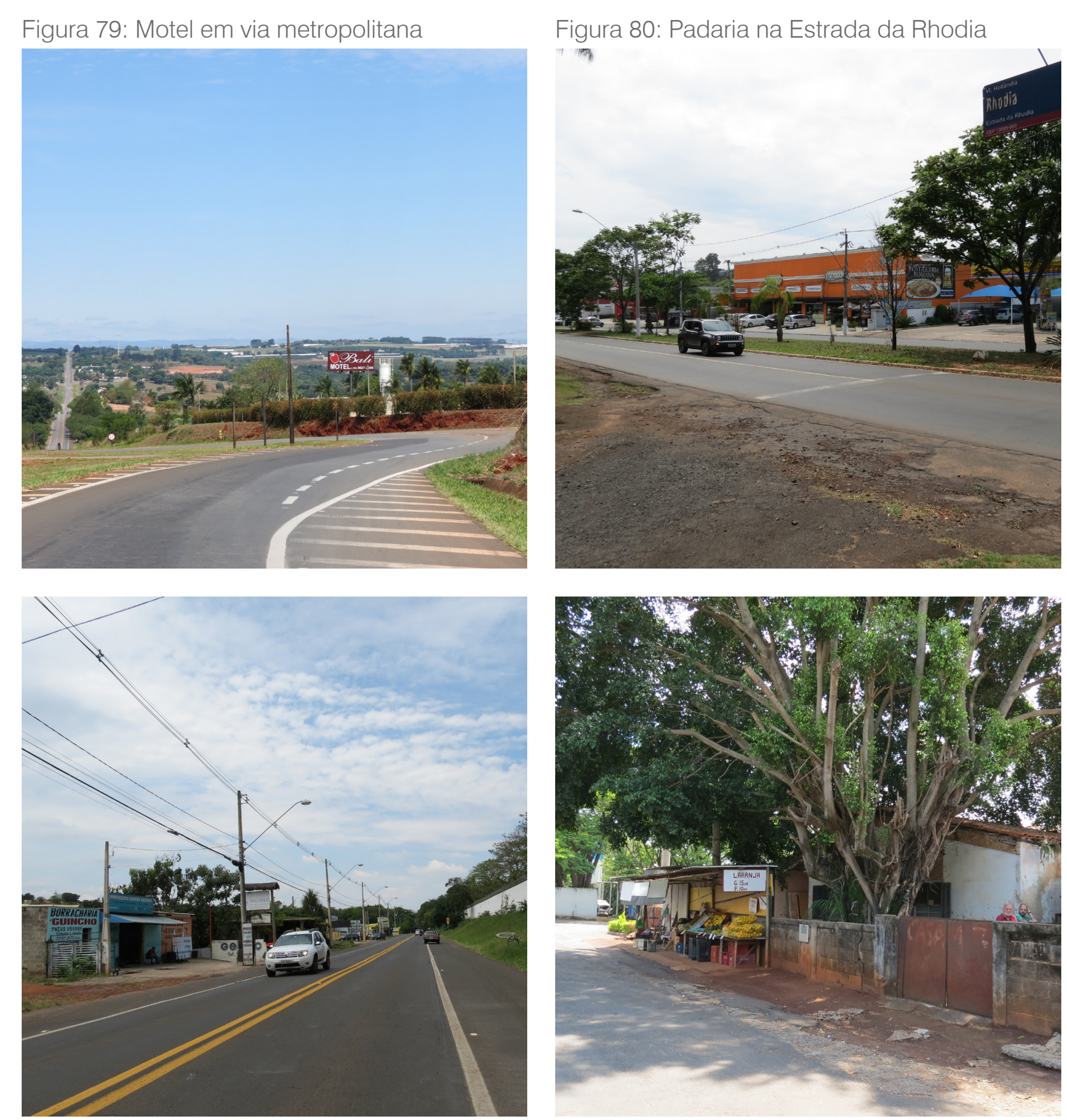

Figura 81: Comércio próximo aos condomínios

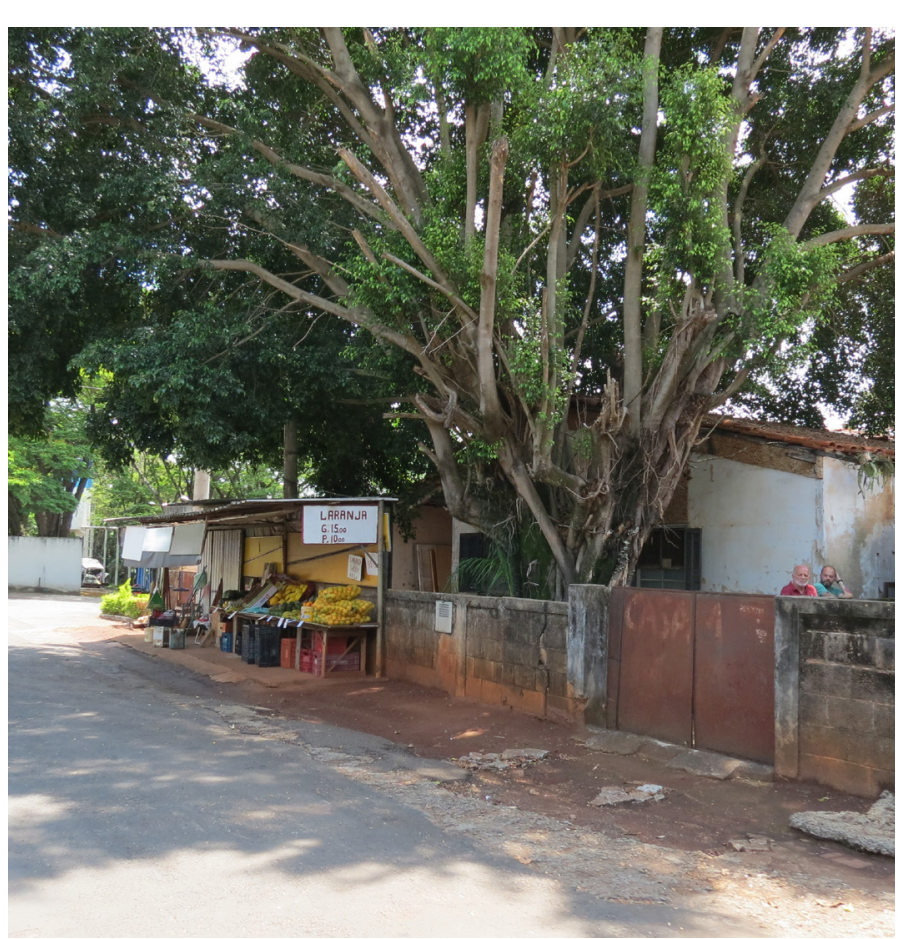

Figura 82: Banca de frutas na Estrada da Rhodia

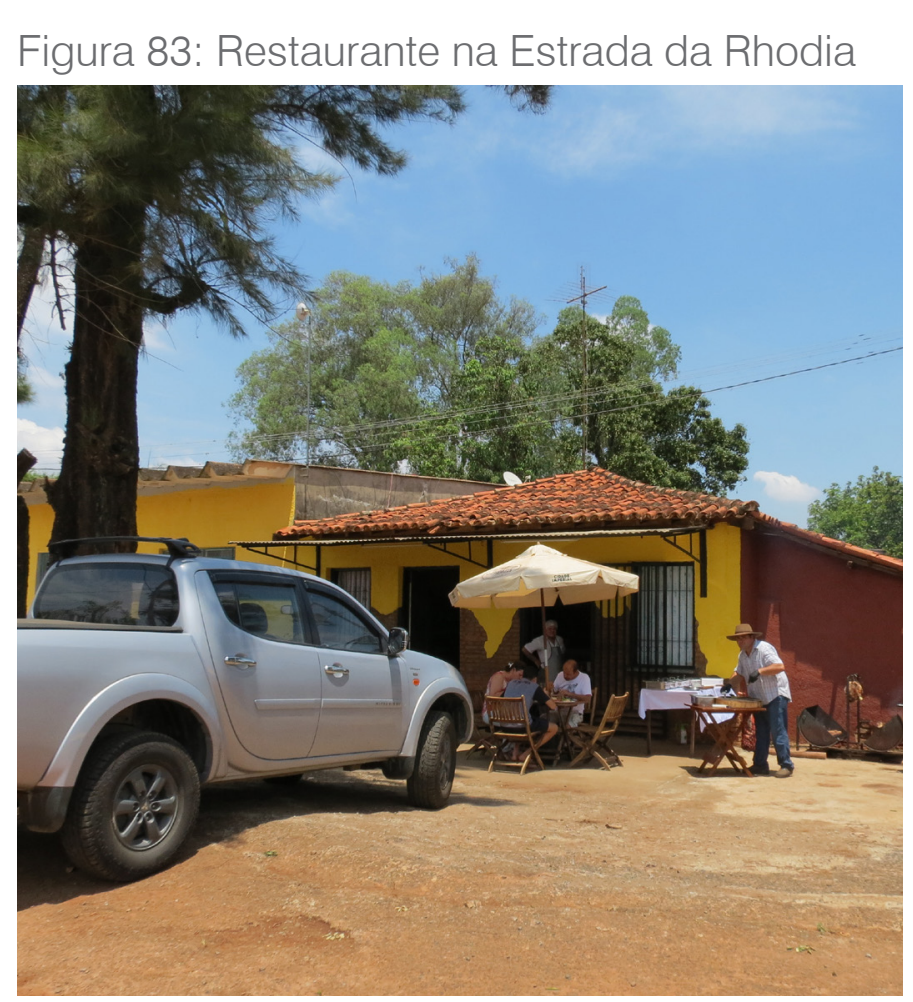

Figura 84: Comércio em via metropolitana

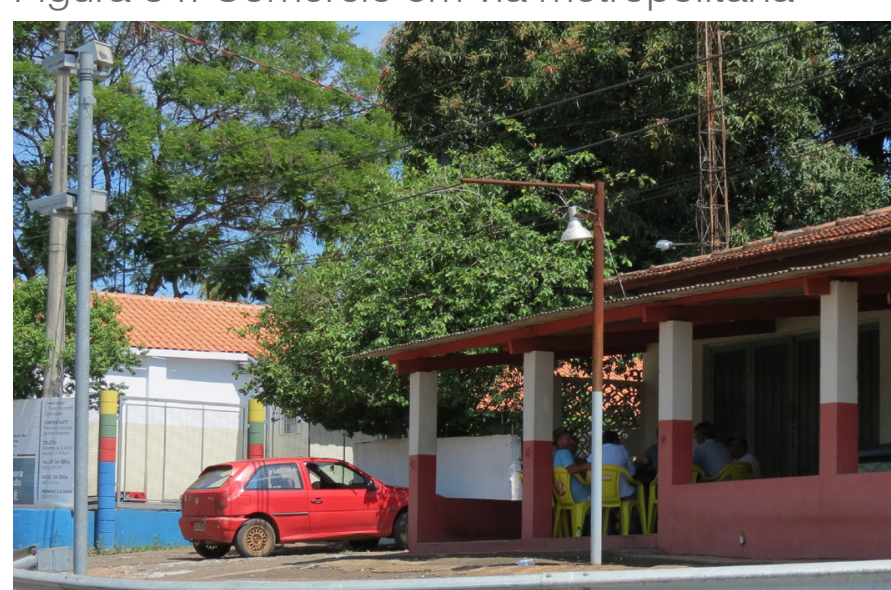

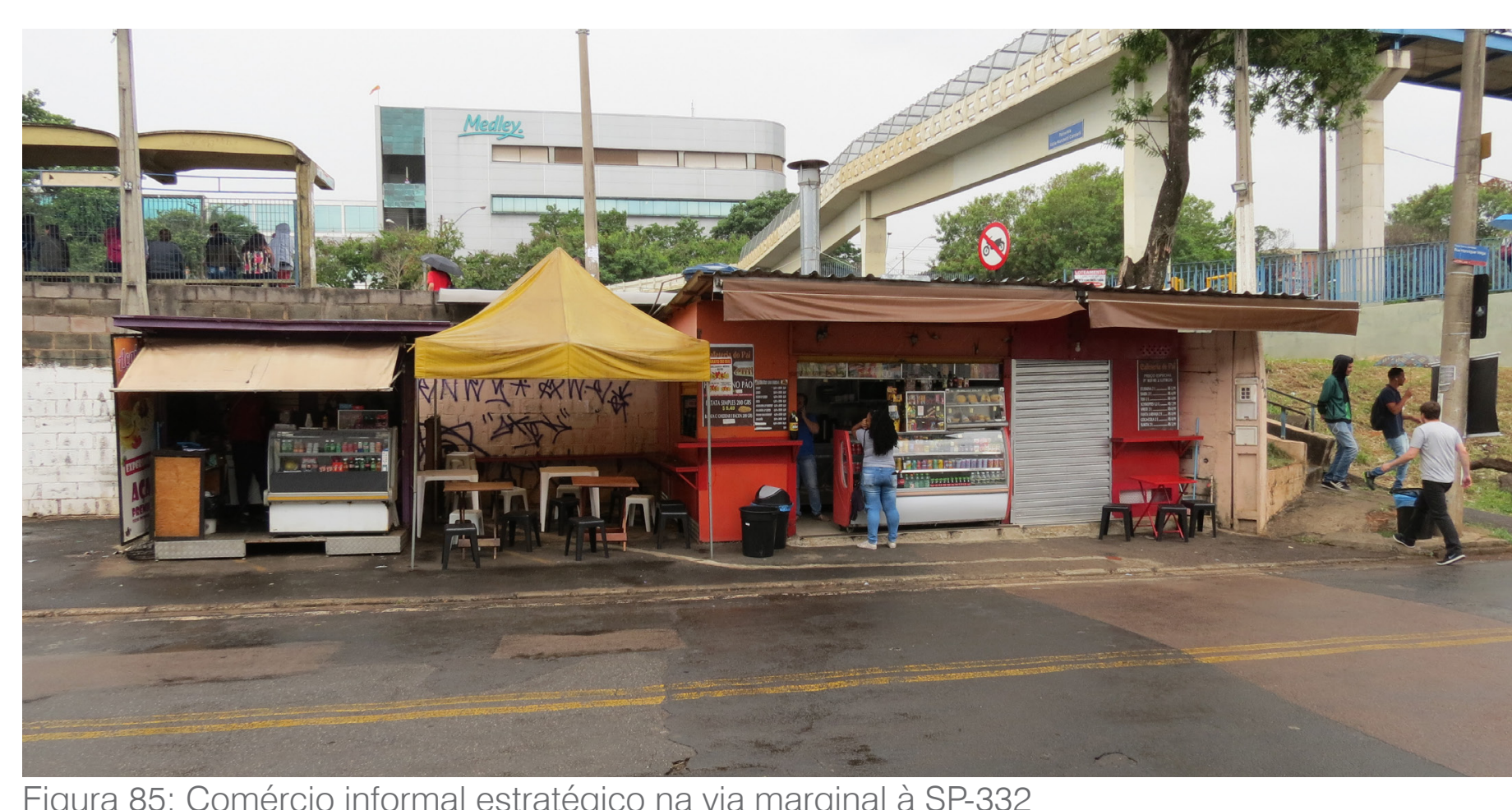




\section{Industrial de pequeno e grande porte}

Assim como apresentado na caracterização da RMC como um todo, é imprescindível tratar das indústrias na caracterização do Vetor 3, visto este eixo também participou da descentralização das indústrias de São Paulo, na década de 1970, e possui grandes empresas instaladas na área. Esse é o caso da REPLAN, localizada na cidade de Paulínia e que possui presença marcante e grande importância econômica para a região. A Figura 86 mostra a refinaria de Paulínia, que ocupa extensa área do distrito industrial, com tanques e chaminés, que se destacam na paisagem da Rodovia SP-332.

A Figura 87 mostra a localização das indústrias no vetor, sendo possível observar que Paulínia e Campinas reúnem a maioria delas, em relação às cidades menores. Pode-se notar, ainda, que ocupam as áreas próximas às vias metropolitanas, estrategicamente, visto que o transporte rodoviário é o principal modo de escoamentos dos produtos produzidos ali.

\section{Figura 86: Imagem aérea da REPLAN, em Paulííia}

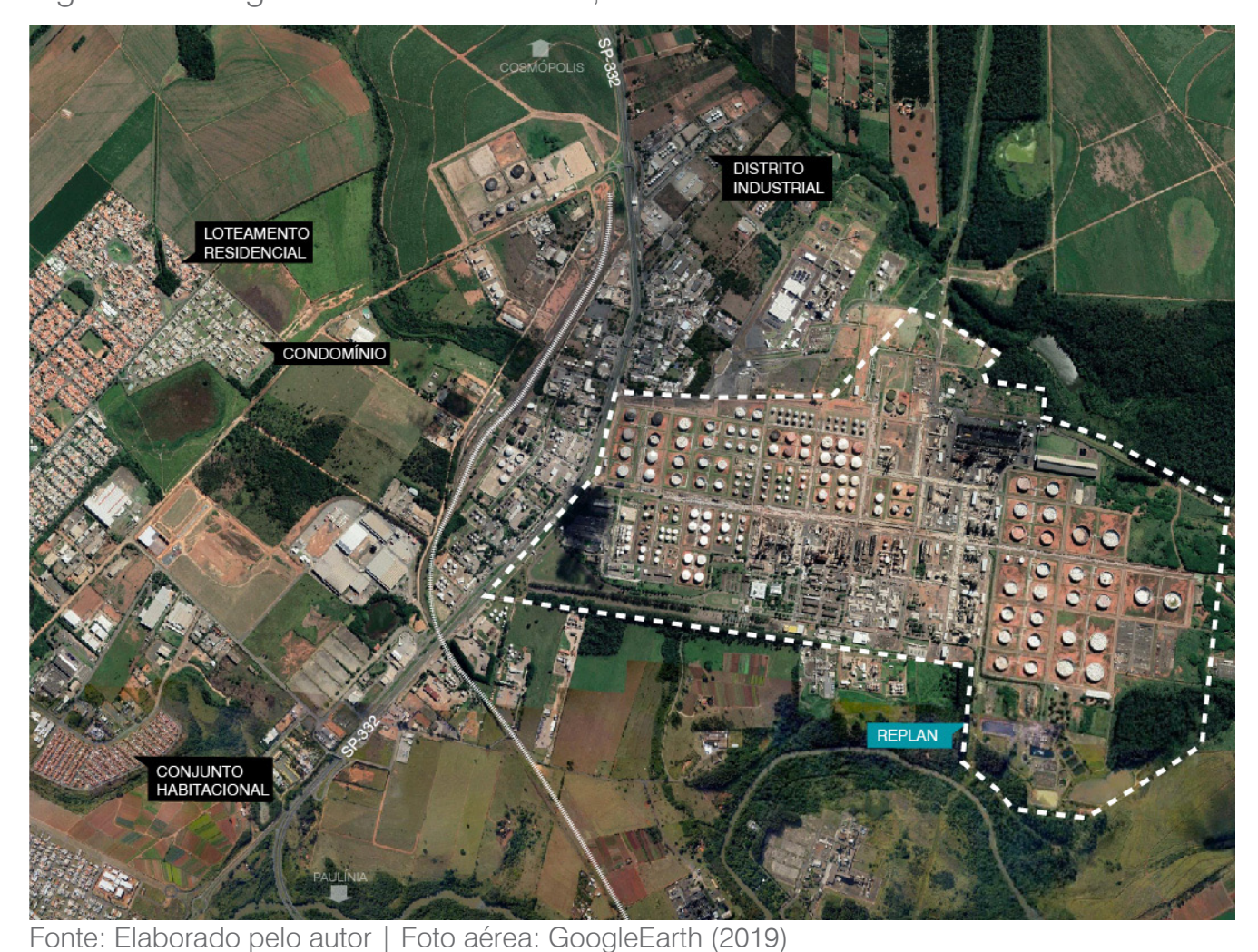

170

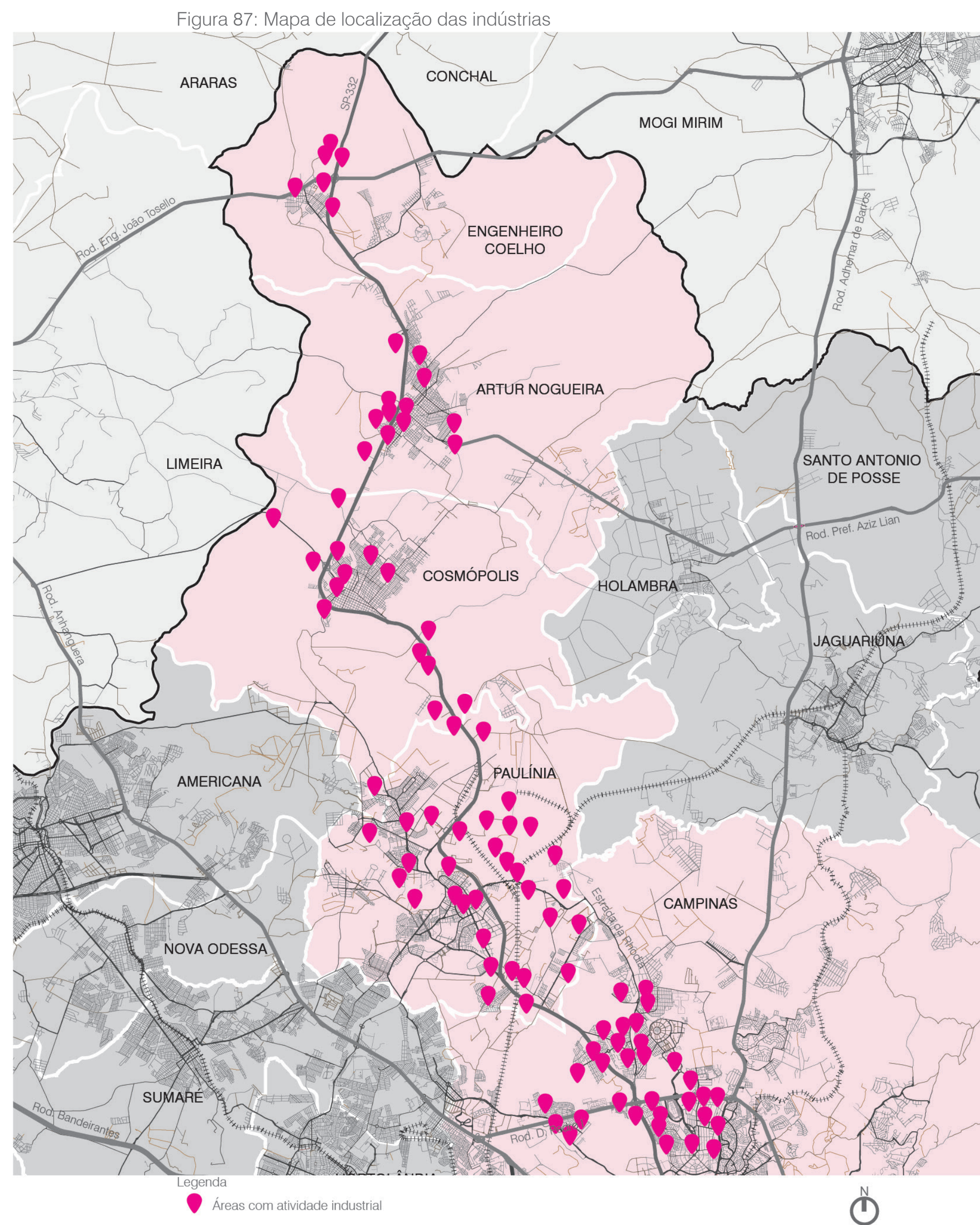

Fonte: Elaborado pelo autor | Fonte de dados: Nascimento, 2013 $5 \mathrm{Km}$ 
A alta densidade de ocupação da região da REPLAN por empresas localizadas próximas entre si, cria uma paisagem coesa, dominada pela atividade industrial, como pode ser visto na Figura 88. Já nas cidades menores, as atividades industriais se misturam com a paisagem rural, uma vez que a ocupação é mais dispersa e divide espaço com a produção agrícola comercial, como é possível ver na Figura 89, em trecho entre Cosmópolis e Artur Nogueira, no qual é possível observar áreas livres desocupadas ao redor das indústrias.

Em relação ao movimento das vias em que estão inseridas, as indústrias têm grande participação, seja nos fluxos de automóveis, ônibus e até mesmo de pedestres. A Figura 90 mostra uma grande empresa localizada na SP-332 e uma passarela à sua frente. A instalação da passarela teve como fator principal a atração da população que trabalha nesta indústria. Já para quem chega por automóvel ou ônibus fretado, o acesso se dá por via marginal à rodovia. Para quem utiliza transporte coletivo metropolitano, o acesso ocorre pela própria rodovia, com pontos de ônibus próximos à passarela.

No entanto, não são apenas grandes indústrias que se instalaram na área. A Figura 91 mostra que as indústrias pequenas, constituídas também por galpões de apoio à logística, geralmente estão localizadas nas vias metropolitanas, como por exemplo, a Estrada da Rhodia ou no distrito de Betel, mais próximas às áreas residenciais
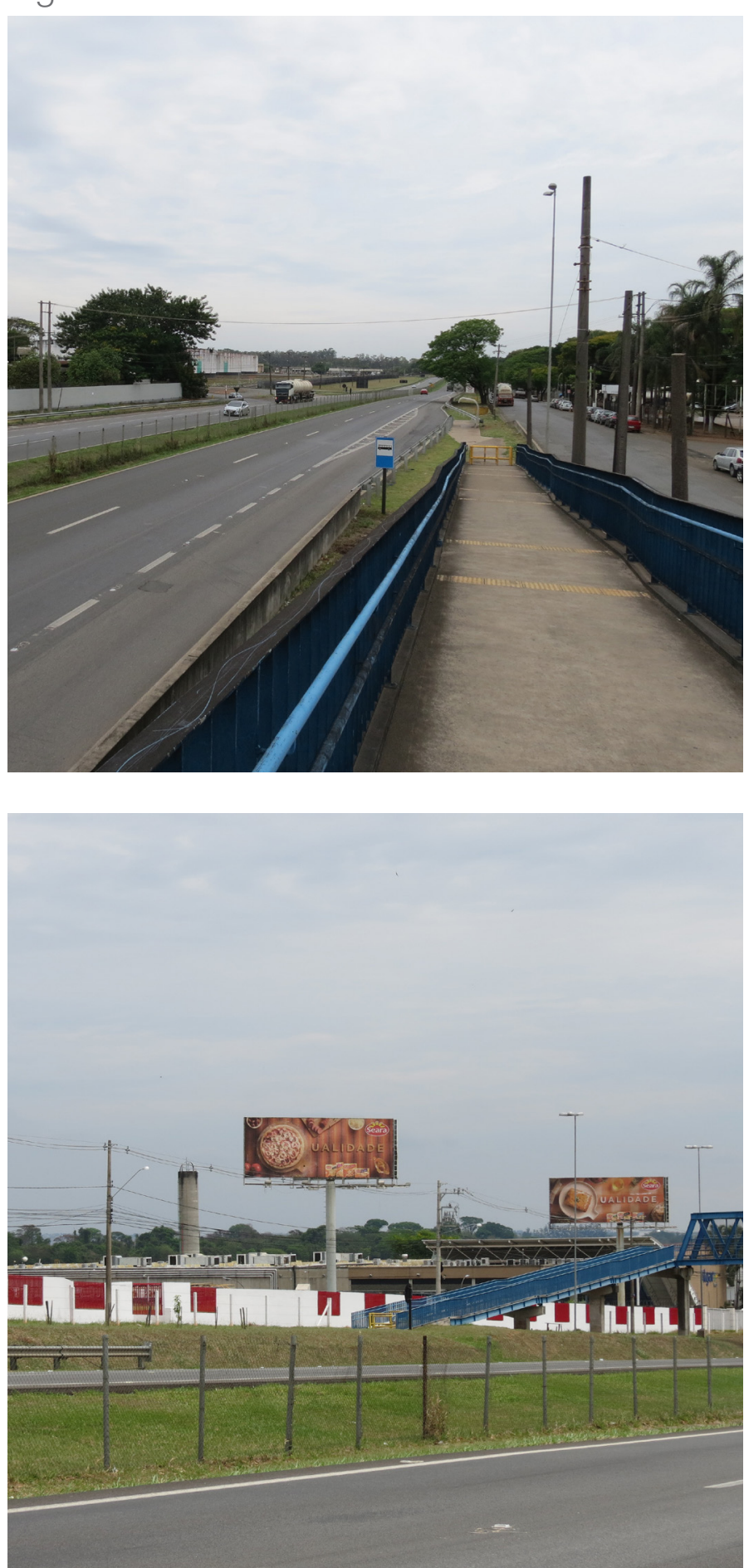

Figura 89: Passarela e grande indústria
Figura 90: Area industrial de Artur Nogueira
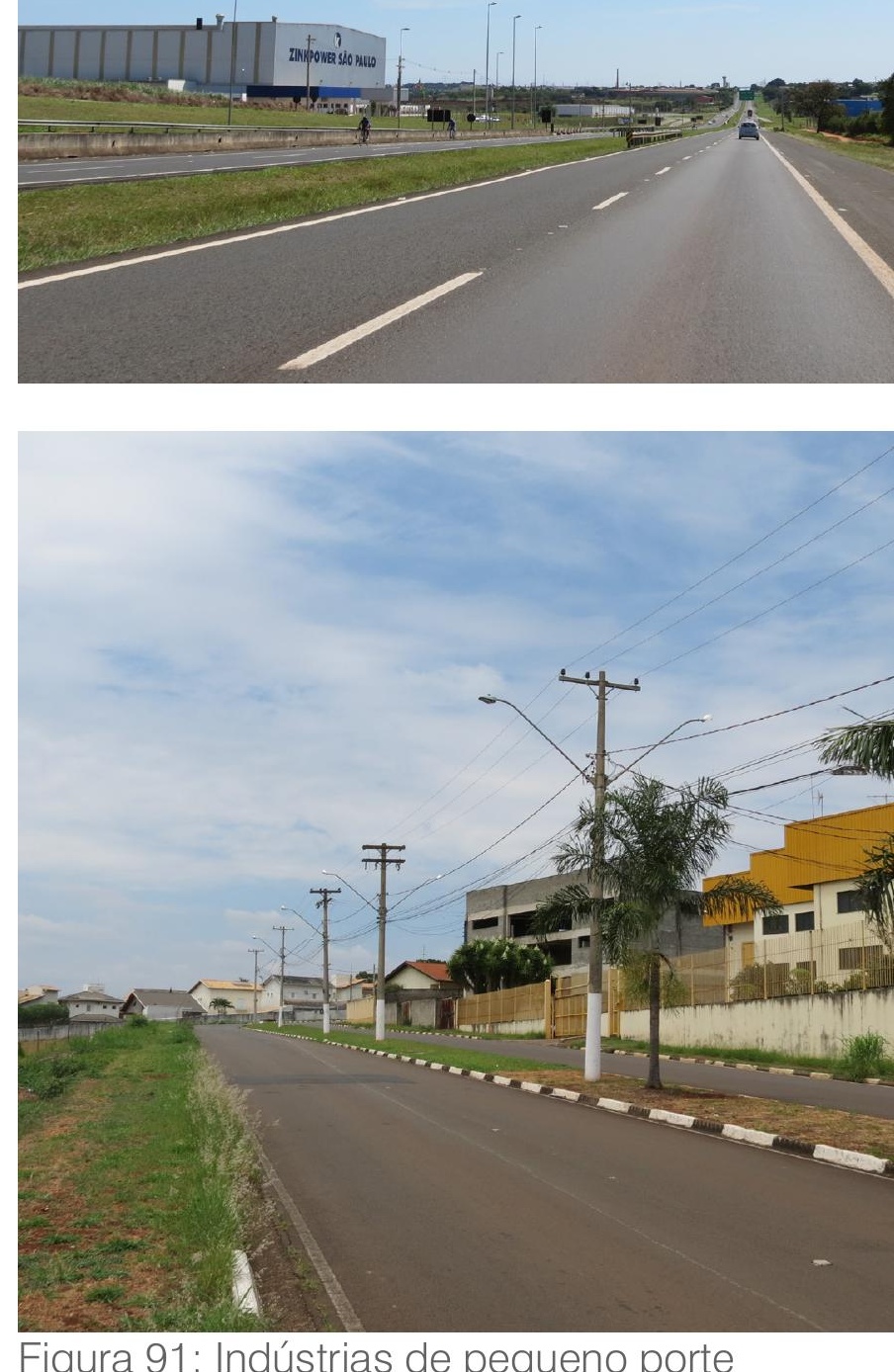

Figura 91: Indústrias de pequeno porte 


\section{Equipamentos}

Os principais equipamentos do Vetor 3 estão localizados, principalmente em Paulínia, que possui equipamentos de grande porte, voltados à cultura e à educação, com importância não apenas local, mas regional, e em Engenheiro Coelho, com a presença da UNASP, em destaque na Figura 93.

Sobre essa universidade, existem algumas questões que envolvem sua atratividade. Enquanto são implantados condomínios de alto padrão ao seu redor, com ocupação recente, a universidade também ocasiona um eixo de expansão vindo da cidade de Artur Nogueira, ainda muito precário. Essa forma de ocupação dispersa, segundo o PDUI da RMC (EMPLASA, 2018b), não viabiliza a construção de uma rede de transportes mais adequada e prejudica o acesso a serviços públicos, além de não gerar espaços urbanos de qualidade. Dessa forma, apesar de ser um equipamento de importância para a educação em toda a região, sua localização apresenta questões urbanas importantes, que envolve o crescimento de duas cidades distintas.

Em Paulínia, os equipamentos têm impacto parecido, uma vez que estão localizados em área de atração do desenvolvimento urbano, nas vias metropolitanas secundárias, de acesso à Anhanguera. A Figura 94 mostra o sambódromo, onde também funciona uma universidade, afastado de toda a ocupação urbana consolidada e à direita, um muro de condomínio com processo de consolidação. Não é só este equipamento que se encontra nesta situação, de atração do desenvolvimento da cidade, mas também o teatro, o terminal rodoviário e o polo cinematográfico.
Figura 93: Imagem áerea da área de implantação da UNASP, em Engenheiro Coelho
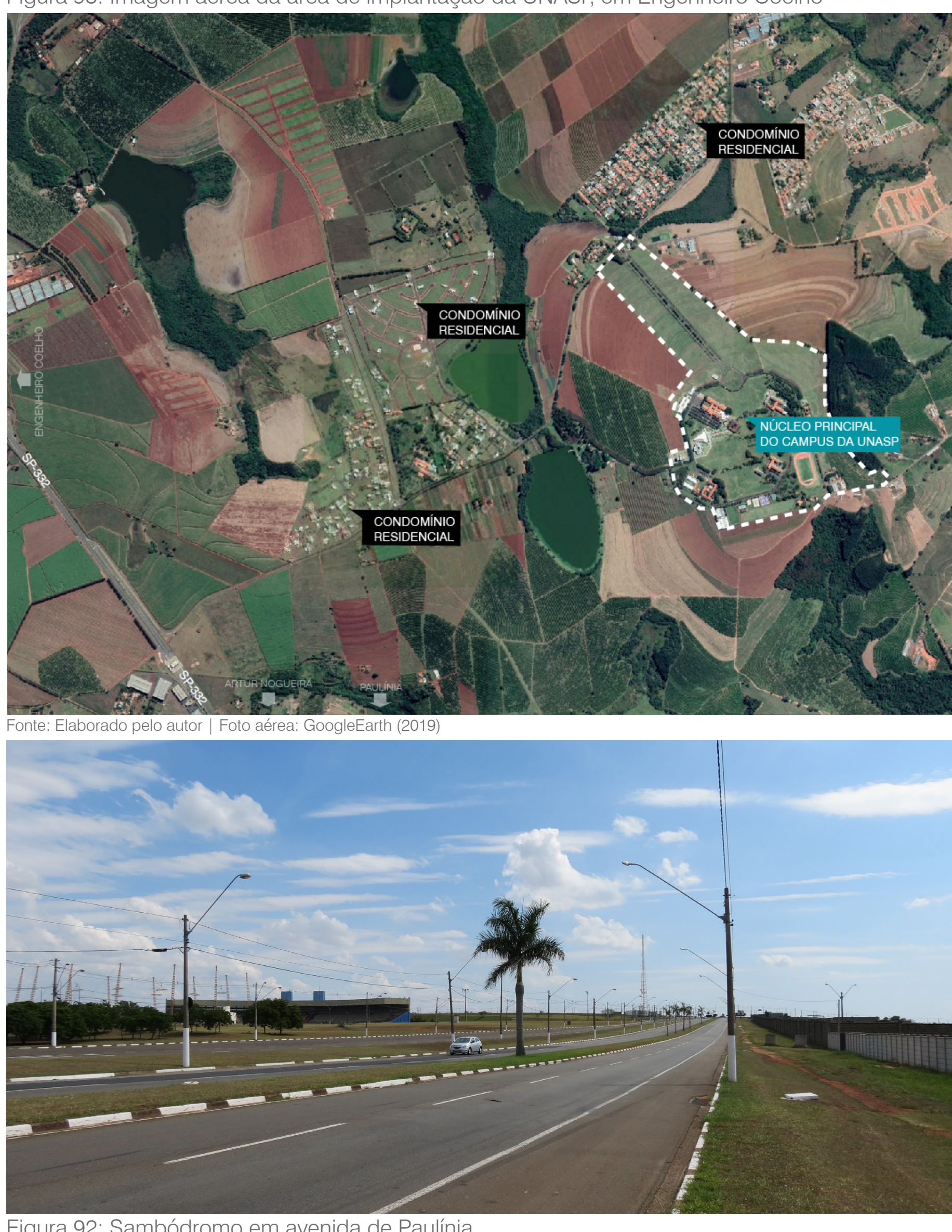

Figura 92: Sambódromo em avenida de Paulínia 


\section{OCUPAÇÃO DAS ÁREAS RURAIS}

\section{Chácaras de veraneio ou moradia}

A dispersão urbana, como já apontado, é uma das principais características de RMC como um todo e, também, do Vetor 3. Ainda assim, na observação do mapa de manchas urbanas, apresentado anteriormente, não foi possível encontrar um dos tipos de ocupação mais comuns na região do Vetor 3, que são os loteamentos de chácaras de veraneio ou mesmo de moradia, principalmente nas áreas das cidades menores. No entanto, esse tipo de ocupação pode ser identificado ao se observar uma foto aérea do município de Cosmópolis, por exemplo, como na Figura 94

Esse tipo de ocupação não é controlado, nestas cidades, já que não configuram áreas urbanas, nem estão dentro dos perímetros urbanos. Com glebas inicialmente grandes, que são gradualmente divididas, com o passar do tempo e com o adensamento da ocupação dos arredores, este processo acaba por induzir a expansão urbana, sem ordenação territorial ou mesmo sem implantação de infraestrutura adequada, desde pavimentação até equipamentos de educação e saúde.

E essas ocupações ocorrem de diversas formas, na relação com o viário metropolitano. Na Figura 95, por exemplo, o loteamento acontece próximo à Rodovia SP-332, na cidade de Engenheiro Coelho, em acesso transversal à via, adentrando a área rural, com diversas ramificações deste caminho principal. Já na Figura 96, o loteamento dá acesso direto à estrada entre Cosmópolis e a Rodovia Prefeito Aziz Lian, o que Ihe garante configuração mais parecida com o espaço intraurbano, cujos lotes possuem testadas para a rua

Outra relação observada foram os loteamentos fechados de chácaras, nos quais as ruas de acesso são fechadas por portões e as divisas totalmente cercadas. Essa forma de ocupação procura criar condições similares a dos condomínios apresentados anteriormente, como forma de garantir segurança e exclusividade no uso dos espaços públicos
Figura 94: Loteamentos de chácaras em Cosmópolis
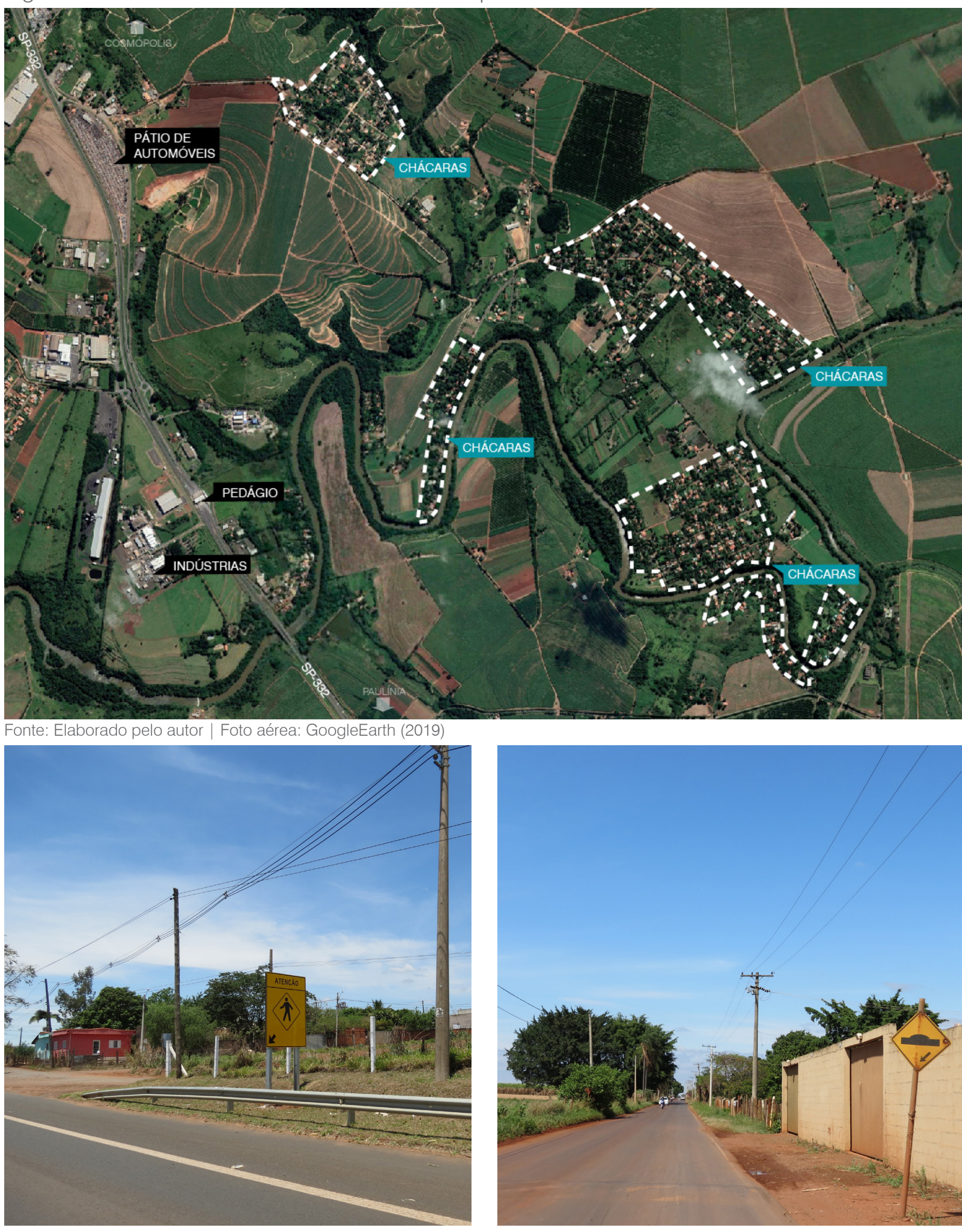


\section{Loteamentos irregulares}

Além das chácaras, também é importante considerar os loteamentos irregulares, que na maior parte das vezes são implantados em áreas rurais, fora do perímetro urbano, participando do fenômeno de dispersão urbana da região. Os conjuntos de chácaras, apresentadas anteriormente, em certo momento também podem se configurar como loteamentos irregulares, visto que passam a ter formas parecidas, dado o desmembramento das glebas.

A Figura 97 apresenta a localização dos loteamentos irregulares no Vetor 3. É possível observar que existe concentração desse tipo de ocupação na região da cidade de Artur Nogueira, que está passando por um processo de regularização fundiária destes loteamentos. Segundo dados do IBGE de 2002, existiam aproximadamente 44 loteamentos irregulares, naquela data. Em 2015, segundo notícias da imprensa local$^{2}$, a prefeitura alegava serem aproximadamente 65 loteamentos irregulares ou clandestinos.

É importante notar que, ainda que existam áreas de ocupação irregulares, de concentração da população de baixa renda nesta área e na região metropolitana como um todo, o que se percebe, no Vetor 3, é uma maior incidência de loteamentos irregulares ocupados por população de classe média, seja na construção de chácaras de veraneio que não cumprem com a legislação vigente, seja pela mudança de padrões nas moradias da população das áreas rurais.

Na pesquisa de campo, foram reconhecidos alguns desses loteamentos. A Figura 98, por exemplo, mostra loteamento irregular na cidade de Artur Nogueira, próximo à Estrada Pref. Orlando Kiosia. Esse tipo de ocupação possui, como características principais, a falta de infraestrutura básica, como pavimentação e drenagem, apesar de ser possível notar que não se encontra em situação precária.

2 Disponível em: https://oregional.net/prefeitura-de-artur-nogueira-regulariza-mais12-loteamentos-ilegais-51802 Acesso em: 15 jan. 2020

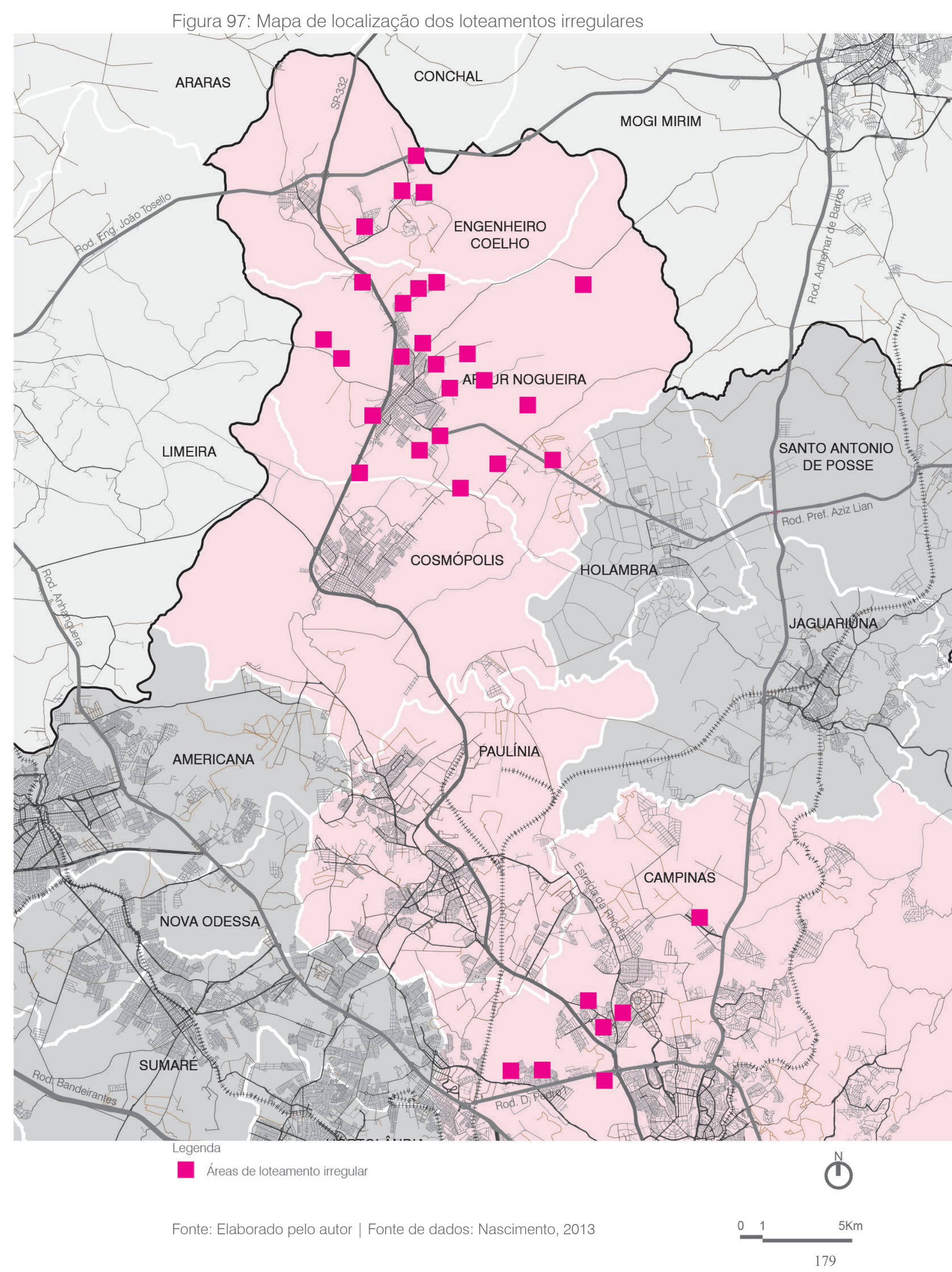


Ainda que sejam essencialmente compostos por chácaras de veraneio, muitas pessoas moram nestes loteamentos, que não possuem equipamentos de saúde, lazer e educação. O acesso a estas atividades ocorre apenas nos núcleos urbanos consolidados, sendo necessário o deslocamento através das vias metropolitanas, geralmente realizado por veículos particulares, sejam automóveis ou bicicletas, visto que não existe atendimento por ônibus urbano ou metropolitano.

Além desse tipo de ocupação irregular, foi identificado, na região de Betel, uma ocupação de casas com características um pouco distintas dos loteamentos de Artur Nogueira. Na Figura 99, é possível observar a existência de algumas residências em via marginal da Rodovia SP-332, que caracterizam a formação de um núcleo urbano, inserido em área rural. É importante destacar sua grande proximidade com área de produção agrícola e, também, com a área da Mata Santa Genebra, reserva florestal tombada, que pode ser vista no plano de fundo da imagem.

Figura 98: Loteamento irregular em Artur Nogueira
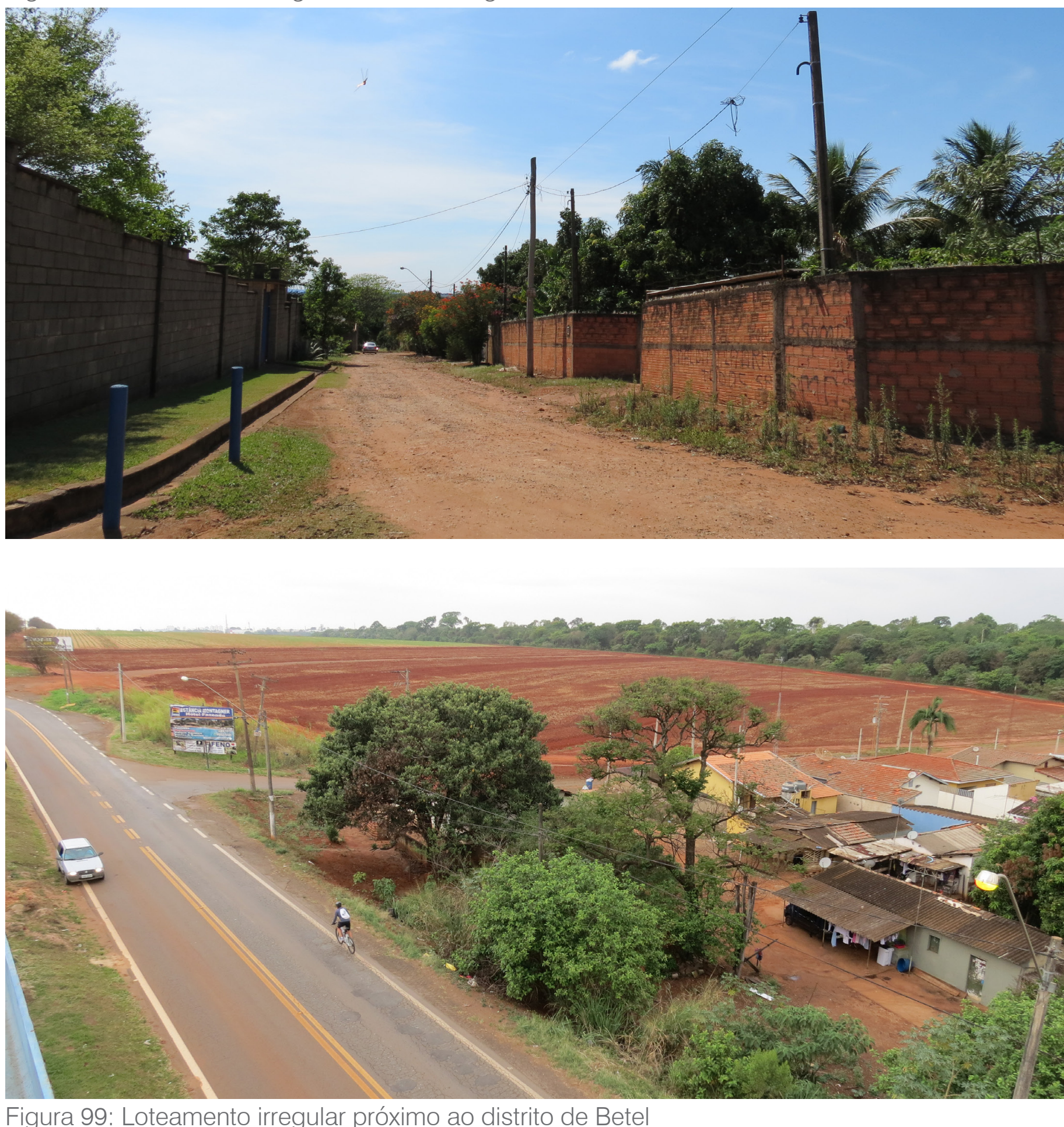


\section{Sítios de produção agrícola comercial}

A produção agrícola comercial do Vetor 3 se concentra basicamente na cana-de-açúcar, nos municípios de Cosmópolis e Paulínia, e laranja, nos municípios de Artur Nogueira e Engenheiro Coelho.

A Figura 103 mostra o cenário típico dessas plantações, com grande extensão de terra e plantio que se aproxima das vias metropolitanas, estradas e rodovias. Na imagem, é possível ver uma plantação de canade-açúcar na Rodovia Americana-Paulínia e, ao fundo, a cidade de Cosmópolis

Já a Figura 104 mostra que a produção rural ocupa não só as proximidades das vias de caráter metropolitano, mas todo o território além da ocupação urbana. Na foto, localizada na cidade de Artur Nogueira, é possível observar que atrás das residências e da indústria, no horizonte, existem grandes extensões de terra com plantação de laranja e de outras culturas.

Figura 103: Área de produção agrícola com área urbana ao fundo
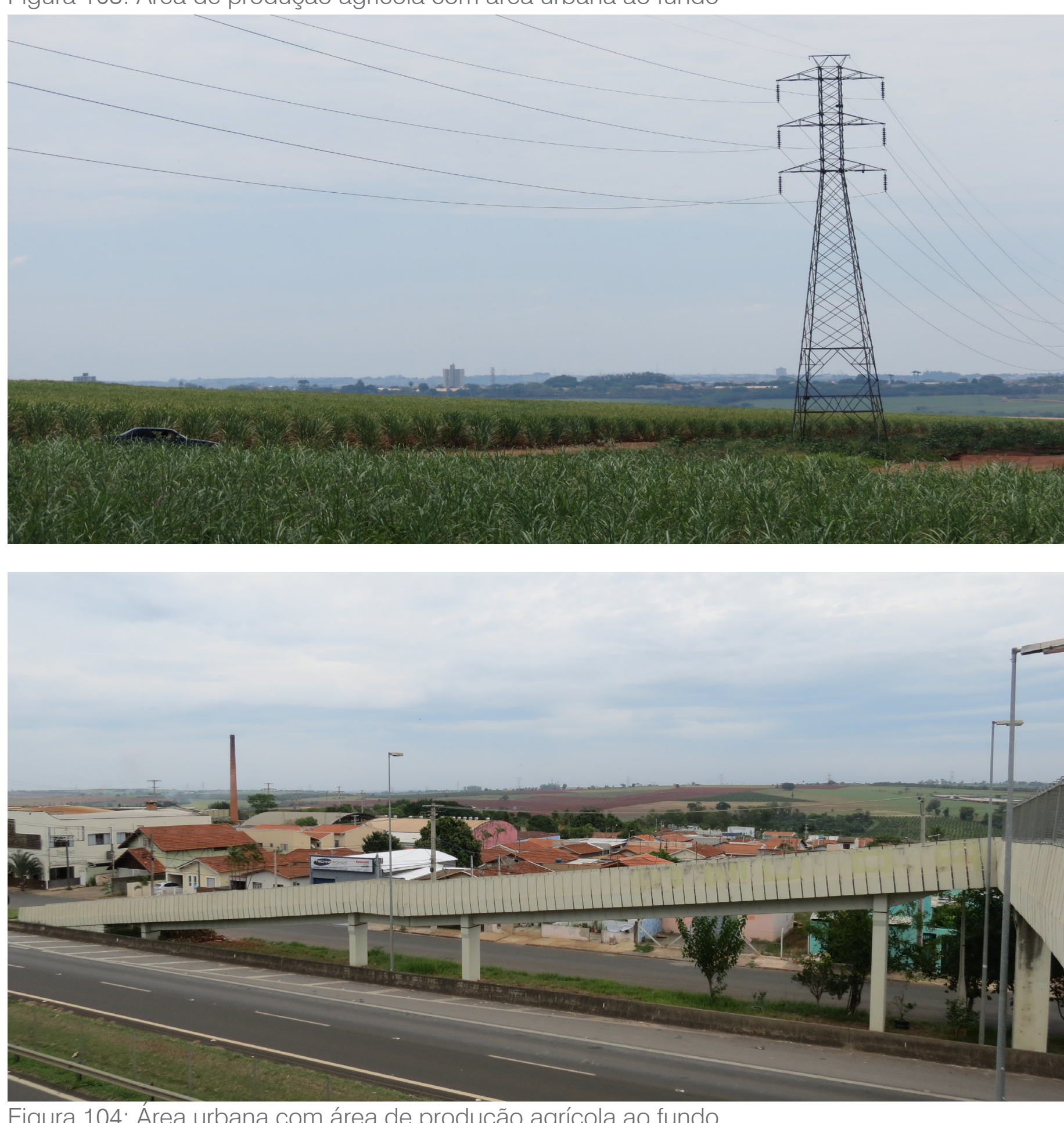

Figura 104: Área urbana com área de produção agrícola ao fundo 


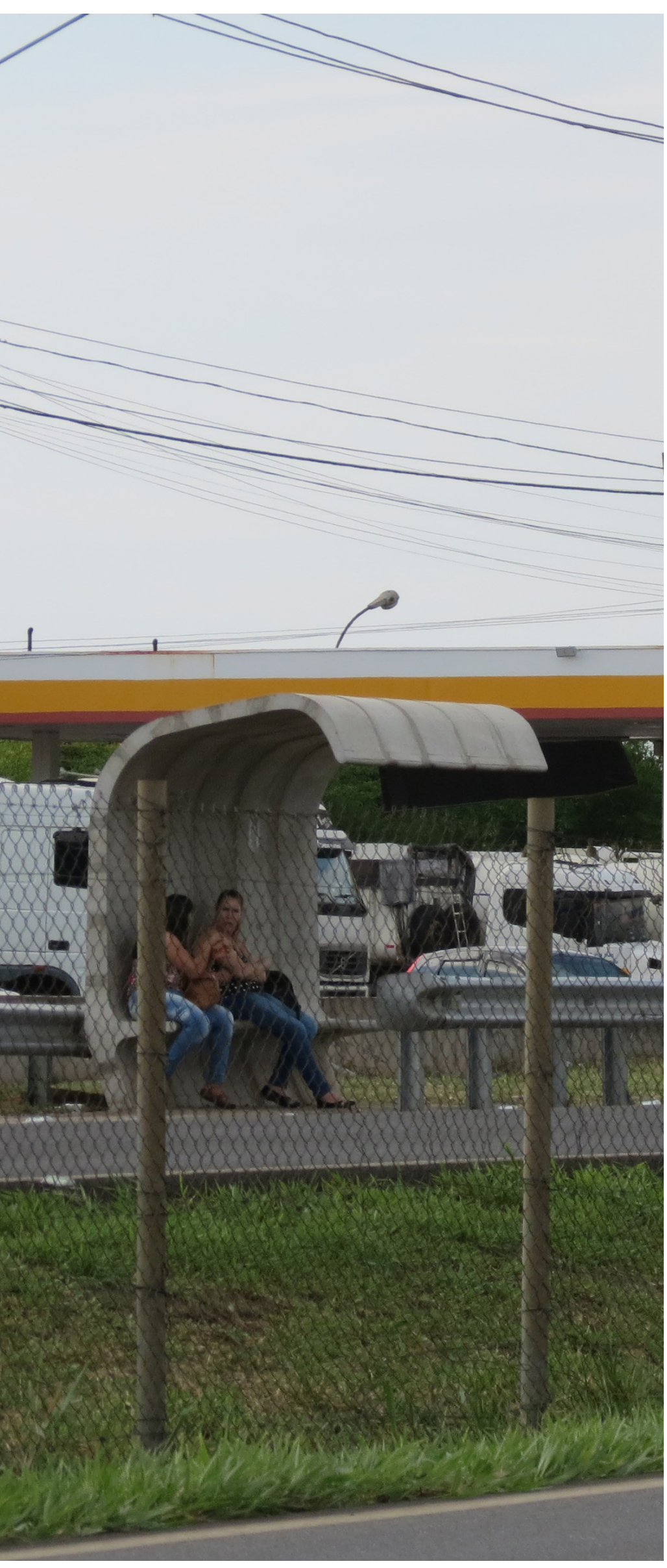

3.3.3. ELEMENTOS DE INTEGRAÇÃO E TRANSPOSIÇÃO DOS SISTEMAS DE TRANSPORTE

Além dos meios de transporte e da ocupação do território metropolitano, apresentados anteriormente, é importante, para caracterização dos espaços da mobilidade do Vetor 3 , incluir os elementos de integração intermodal. Dessa forma, serão apresentados, a seguir, os pontos de ônibus, as passarelas e as travessias. Neles é que geralmente estão concentradas a vida pública metropolitana e as dinâmicas da população que habita as rodovias, estradas e vias, objetos desta pesquisa.

Ainda que façam parte dos sistemas de transporte e estejam intimamente relacionados à mobilidade da população, estes elementos também são lugares da permanência, seja pela espera dos ônibus, ou por abrigarem os encontros diários, as relações comunitárias e de vizinhança. A apropriação dos espaços da mobilidade tem nestes lugares o meio de se realizar, uma vez que é através deles que o homem, na sua versão lenta, se aproxima da velocidade da rodovia. 


\section{Pontos de ônibus}

Ainda que sejam poucas as linhas metropolitanas que circulam pelo território do Vetor 3 , conforme demonstrado na caracterização das linhas de ônibus metropolitanos, é grande a variedade de tipos de pontos de ônibus e de suas inserções no território.

O mapa a seguir (Figura 105) mostra todos os pontos de ônibus localizados nas linhas que trafegam pela SP-332 em direção à cidade de Engenheiro Coelho. É possível observar que a maior concentração de pontos de ônibus está relacionada à proximidade dos núcleos urbanos (ou dentro deles) e das indústrias. O trajeto de aproximadamente $60 \mathrm{~km}$ de extensão, apresenta aproximadamente 95 pontos de parada. A maior distância entre eles, na rodovia, é de aproximadamente de $4 \mathrm{Km}$ e as menores distâncias de aproximadamente $400 \mathrm{~m}$, podendo ser menor em alguns trechos dos núcleos urbanos.

É interessante notar que, embora façam parte de uma mesma linha, cada ponto de ônibus tem uma condição de inserção diferente e até mesmo um padrão de construção distinto. Essa condição pode variar de acordo com a maior ou menor frequência de usuários ou pela implantação em território de um município maior ou menor.

Em Campinas, por exemplo, os pontos de ônibus apresentam maio concentração de pessoas, já que atendem também aos ônibus municipais nos mesmos locais. O que está mostrado na Figura 106 possui acesso direto à rodovia, com área específica para aproximação do ônibus e embarque dos passageiros. É importante notar que existe o cuidado na reserva de espaços para o ônibus, mas não para o usuário. É possível observar na imagem que não existe espaço adequado na área de embarque e desembarque, sendo necessário que o usuário saia da sua área de proteção para acessar o veículo. Essa condição coloca o usuário em risco e não considera a acessibilidade das pessoas com deficiência como parâmetro na implantação do ponto.

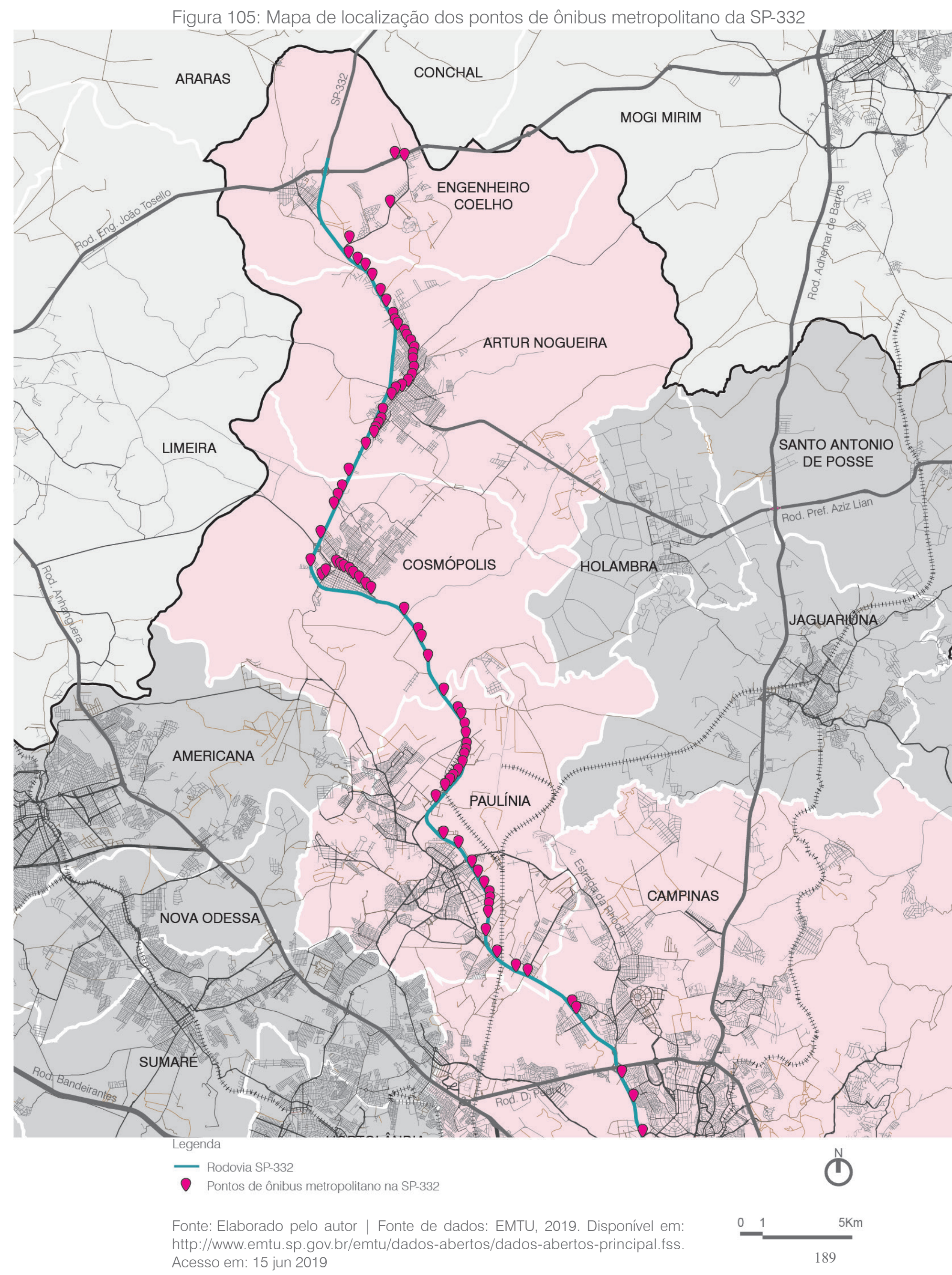


O tipo de ponto mostrado na Figura 107 é mais comum nas áreas entre os municípios de Campinas e Paulínia, próximos aos distritos de Betel e Barão Geraldo. Apesar de fornecerem maior proteção das chuvas, visto que estão em locais abertos e com bastante incidência de ventos, sua condição não oferece segurança para os usuários. Seu acesso ocorre por calçada que margeia a rodovia, protegida por guard rail e o embarque e desembarque ocorre em área de aproximação específica do ônibus.

Ainda na região de Paulínia, é importante mostrar que os pontos de ônibus estão localizados, muitas vezes, próximos às passarelas, como mostrado na Figura 108. Isso ocorre nas áreas industriais ou nas áreas de maior ocupação do território, próximas à Rodovia SP-332, por onde trafegam os ônibus metropolitanos. É comum, nestes casos, que existam áreas maiores de acomodação do ônibus no embarque e desembarque, além da proteção dos usuários por meio de guard rail. É importante destacar que a falta de iluminação destes pontos faz com que sejam lugares inseguros no período noturno.

Nos núcleos urbanos, os pontos de ônibus são mais tradicionais, oferecendo infraestrutura, inclusive de iluminação, além de seu acesso ocorrer em áreas mais seguras para os usuários. Sua localização, inclusive serve de referência nas cidades, tornando-se locais de encontro de caronas e de parada de ônibus fretado das indústrias da região. Geralmente estão em locais estratégicos da cidade, próximos às vias transversais que estruturam o espaço urbano.

Na Figura 109, o ponto de ônibus está localizado na cidade de Cosmópolis em via metropolitana secundária, próxima ao acesso à Rodovia SP-332. Esta via estrutura o sistema viário da cidade, uma vez que permite sua conexão tanto com a SP-332 quanto com a Rodovia SP-133, que faz conexão com a Rodovia Anhanguera, além de cruzar com todas as avenidas principais da cidade, servindo de captação dos fluxos internos em direção à outras áreas da metrópole.

Ao contrário das áreas intraurbanas, que possuem maior infraestrutura

Figura 106: Ponto de ônibus em Campinas
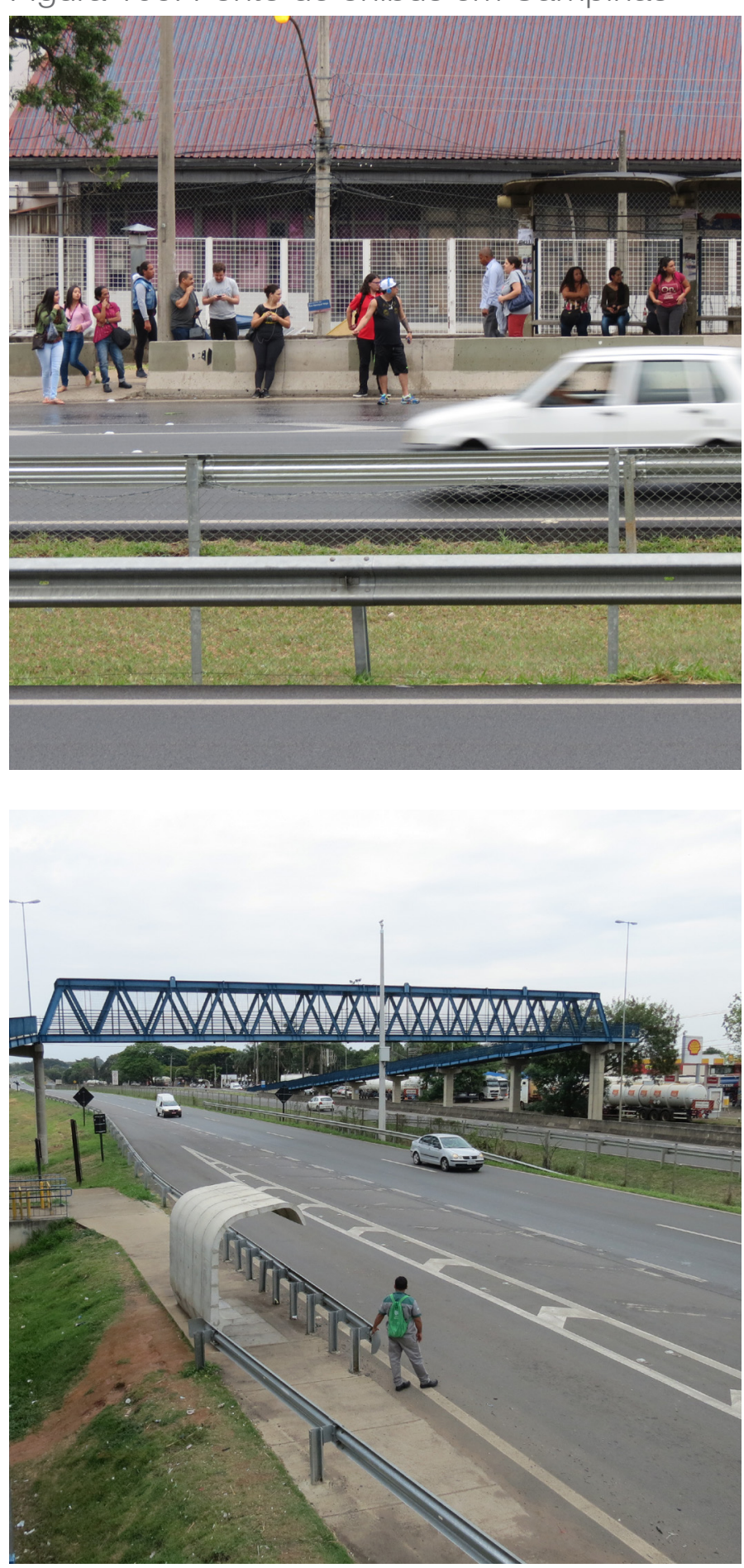

Figura 108: Ponto de ônibus em área industrial
Figura 107: Ponto de ônibus em Paulínia
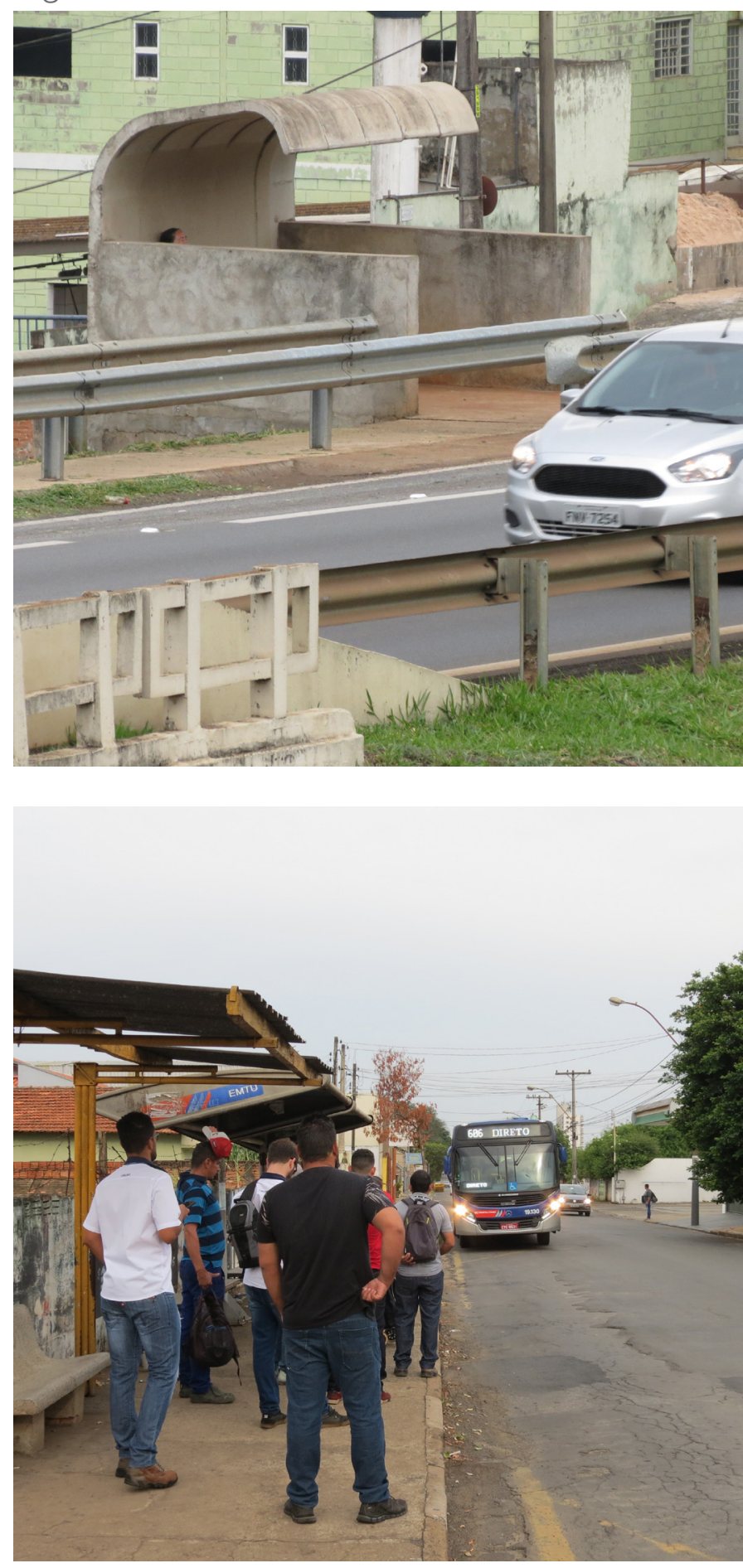

Figura 109: Ponto de ônibus em Cosmópolis 
para os pontos de ônibus, nas áreas de dispersão urbana, com ocupação fragmentada, os pontos de ônibus geralmente não oferecem infraestrutura completa, sendo o abrigo improvisado ou sem manutenção. O acesso também acontece por caminhos não pavimentados, como mostrado na Figura 110, localizado na Rodovia SP-332, no acesso ao distrito de Betel.

Outra situação bastante comum no trajeto do ônibus metropolitano que trafega pela SP-332 é que, nas áreas de menor ocupação, os pontos não possuam sinalização, dispositivos de proteção, acesso adequado ou abrigo, como mostra a Figura 111. Nestes casos, o embarque é realizado no acostamento da rodovia. Tomar o ônibus nestes pontos, só é possíve para o usuário que conhece os trajetos e use regularmente o sistema.

Nas vias metropolitanas, principalmente as estradas, os pontos de ônibus podem variar de acordo com a ocupação lindeira da via. Na Figura 112, o abrigo possui cobertura adequada, locais protegidos para espera, além de sinalização. Apesar de não permitir o acesso de pessoas com deficiência possui claramente um projeto arquitetônico relacionado à portaria do condomínio, que fica logo ao lado e que, provavelmente, realiza a sua manutenção

Em outros trechos de estrada, no entanto, com ocupação de renda mais baixa, o abrigo não possui cobertura por falta de manutenção, os caminhos de acesso são precários ou inexistentes e o embarque é realizado no acostamento, como pode ser observado na Figura 113. O ponto de ônibus está localizado na Rodovia Pref. Aziz Lian, em área de ocupação dispersa de baixa renda, no município de Artur Nogueira.
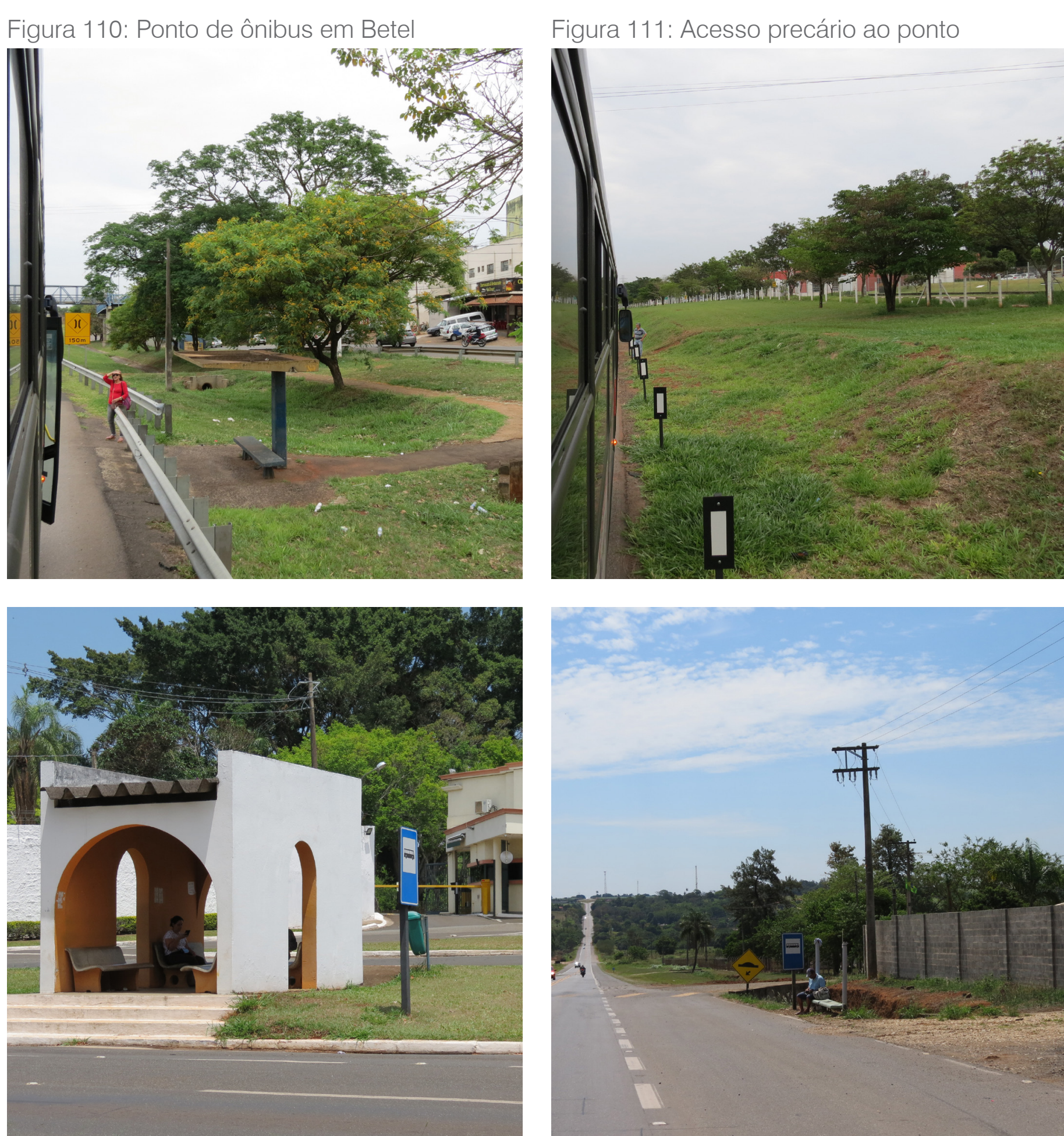

Figura 112: Ponto de ônibus dos condomínios

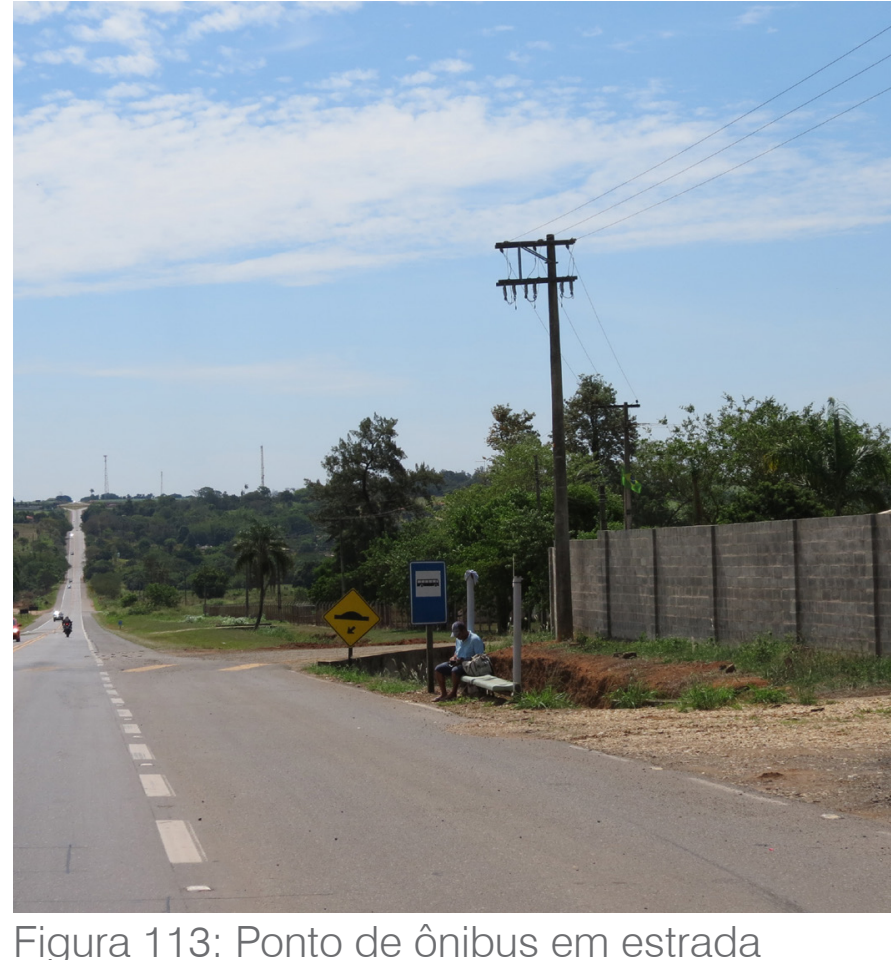




\section{Passarelas, Passagens e Travessias}

As travessias, passagens e passarelas que ocorrem no eixo em estudo se diferenciam pela sua inserção no sistema e pelas condições de ocupação lindeiras às vias. Durante as entrevistas realizadas, foi possível identificar dois tipos de passarela. O primeiro tipo são as que servem como travessias próprias ao espaço das cidades, como no caso das passarelas de Artur Nogueira e Cosmópolis, que se localizam próximas aos núcleos urbanos e têm como principal função integrar bairros dispersos do núcleo, separados pela Rodovia SP-332. Seus fluxos principais dizem respeito às dinâmicas cotidianas da população que precisa acessar o centro.

O outro tipo de passarela são as que servem às ocupações lindeiras à via na maior parte das vezes em zonas industriais. Nestes casos, os maiores fluxos de pessoas são as que cruzam para acessar o outro lado do sistema viário, para utilizar os pontos de ônibus e poder fazer os trajetos de ida e volta do trabalho, como é o caso da maioria das passarelas de Paulínia e Campinas

A Figura 114 mostra a posição de todas as transposições possíveis da Rodovia SP-332, sejam elas por túneis e viadutos, com espaços reservados apenas para veículos motorizados, sejam por passarelas próprias para os pedestres e ciclistas. As transposições para os veículos existem em maior quantidade, espalhadas de forma constante pelo território. Já as passarelas são localizadas em pontos específicos, como próximas aos núcleos urbanos ou às áreas industriais.

Nas vias metropolitanas e metropolitanas secundárias, consideradas nos trechos em estudo, as travessias são realizadas em nível, com sinalização de trânsito, como faixas de pedestres, em alguns casos, principalmente no interior dos núcleos urbanos consolidados. Em outros casos, geralmente de menor fluxo, a sinalização é inexistente e as travessias são realizadas de forma desordenada. Estas situações estão localizadas, na maior parte das vezes, nas áreas de ocupação dispersa ou nas estradas de acesso às áreas rurais.

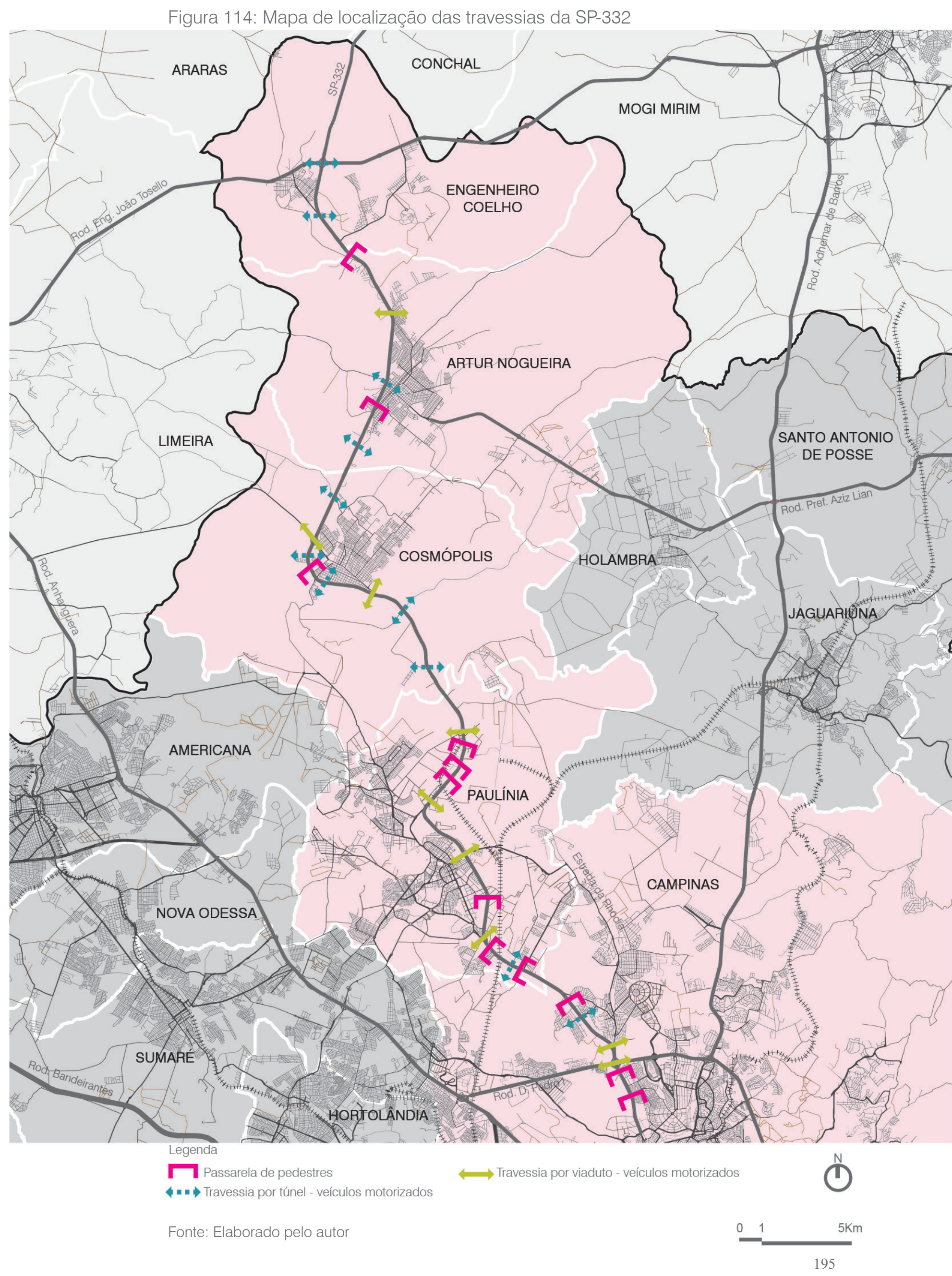


O primeiro tipo de passarela, citado anteriormente, é a que integra trechos dispersos das cidades, principalmente as cidades menores, como Cosmópolis e Artur Nogueira. Por elas acontecem os deslocamentos cotidianos de parte da população que só possuem essa opção de travessia da rodovia. Em alguns casos, existem tentativas de garantir o acesso confortável à passarela, por meio de praças arborizadas, como é o caso da Figura 115. Localizada em Artur Nogueira, sobre a Rodovia SP-332, esta passarela possui, em seu acesso, uma praça em potencial que é pouco explorada. O tratamento do espaço não atende nem os fluxos mais comuns, como se observa nas marcações do gramado, nem se desenvolve como espaço público de estar para benefício da cidade.

Nem sempre no acesso à estas passarelas de integração da cidade, cortadas pela rodovia, existe um espaço adequado para acesso da população. Em alguns casos, como do outro lado desta mesma passarela em Artur Nogueira, existe, como acesso, apenas um canteiro sem pavimentação ou sinalização adequados, como pode ser visto na Figura 116. Ainda que a passarela tenha inclinação correta, o acesso por pessoas com deficiência é dificultado, se não impossibilitado, pelos elementos que a rodeiam

No caso de Cosmópolis, a inserção da passarela deixa mais evidente a dispersão urbana que ocorre em função da rodovia, mostrado pela Figura 117. Na paisagem da Rodovia SP-332, ela parece descolada de qualque ocupação urbana. No entanto, esta é a única opção para conexão entre os bairros Parque Real e Santana com o núcleo urbano consolidado Importante notar que a falta de integração dos bairros obrigou que a passarela tivesse acesso por meio de uma calçada lindeira à rodovia protegida por barreiras do tipo new jersey de um lado e um guarda corpo do outro, que as leva à entrada da cidade. A iluminação pública, com postes em espaçamento de dimensões urbanas, também se destaca na paisagem, assim como a presença de cercas que buscam impedir a perigosa travessia em nível, pelos pedestres.

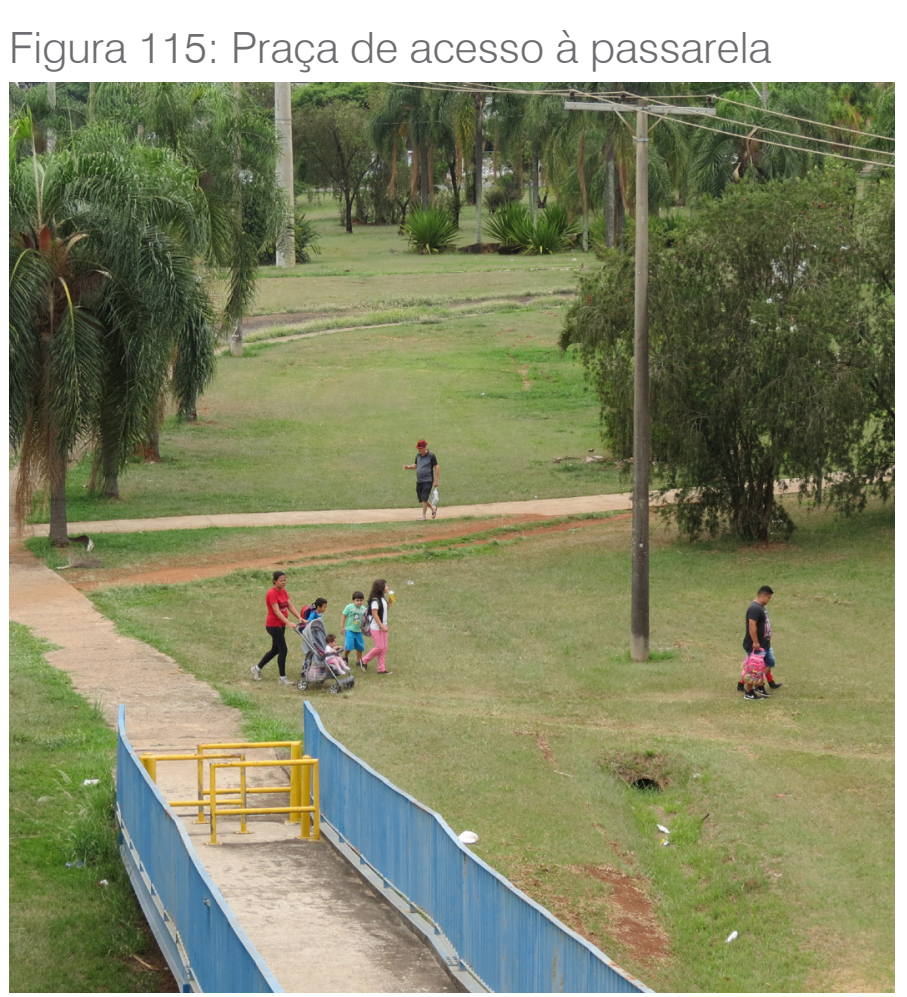

Figura 116: Acesso precário à passarela
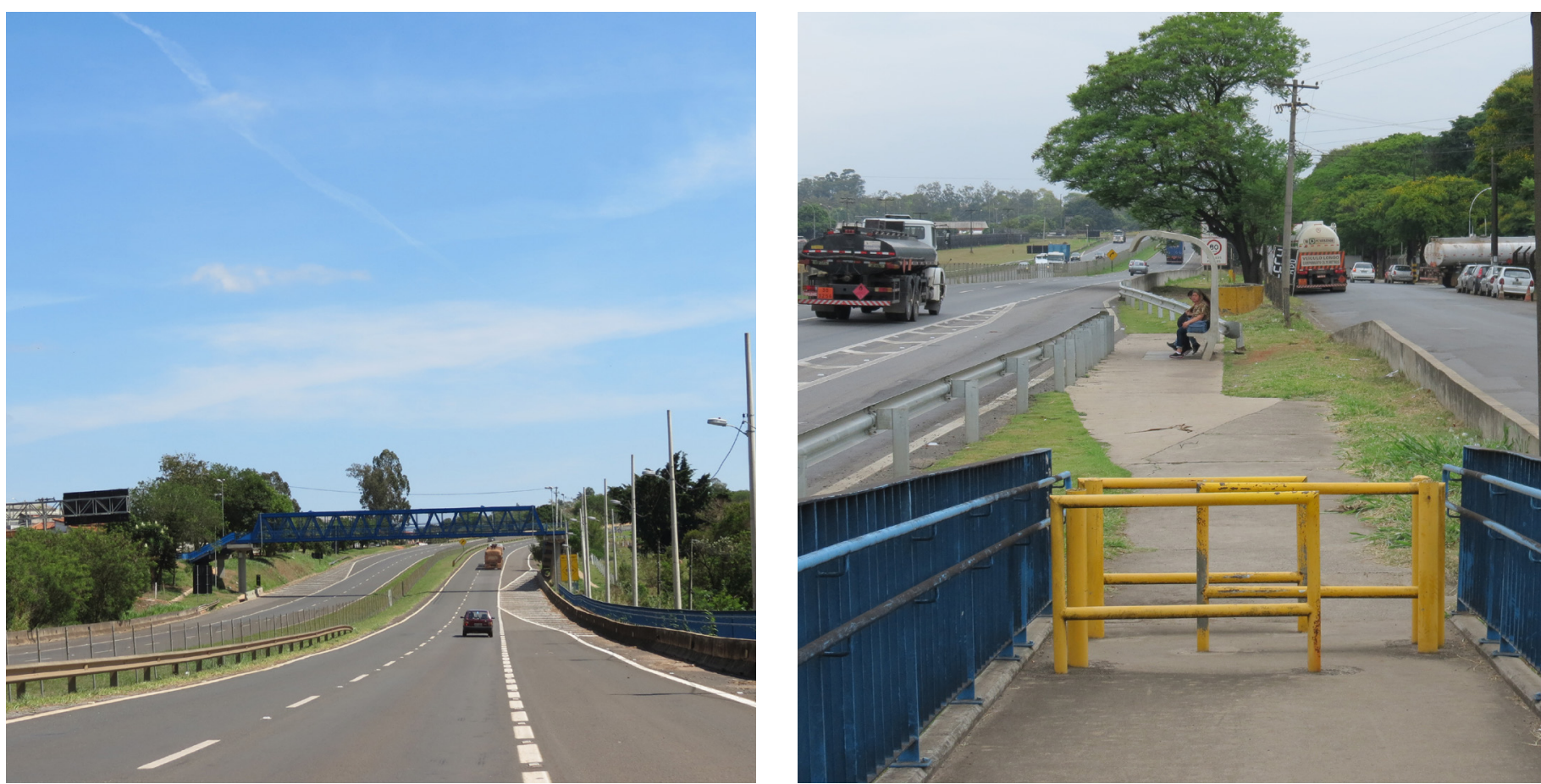

Figura 117: Passarela de integração da dispersão Figura 118: Dispositivo típico de acesso

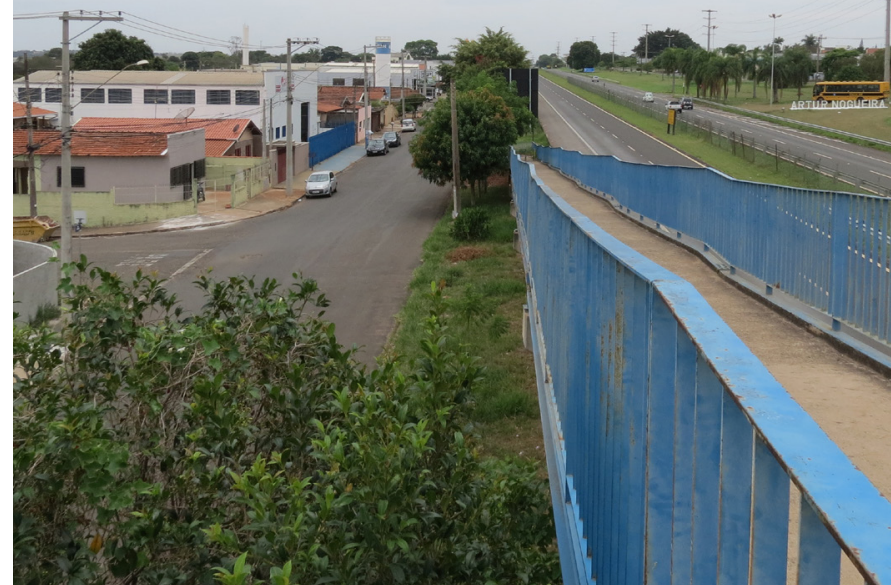


Todas essas passarelas possuem um dispositivo típico nos seus acessos, mostrado na Figura 118. São barreiras que tem como objetivo impedir a passagem de motocicletas pelas passarelas. Esse tipo de solução para os acessos revela a falta de cruzamentos e retornos para esse modal. Apesar de controlarem o acesso de motocicletas, tais barreiras impedem a circulação de pessoas em cadeiras de rodas e dificultam a passagem de ciclistas.

Além de evidenciar essa questão, a imagem mostra a configuração típica do acesso das passarelas que estão próximas às indústrias. Esse é o segundo tipo de passarela encontrado na SP-332, com função de conexão das atividades lindeiras e dos usuários com os sistemas de transporte. Neste caso, os pontos de ônibus, geralmente, encontram-se logo à frente da passarela, com trecho de pavimentação entre os elementos, ainda que precária. Importante notar que a calçada não permite conexão com a via marginal nem às indústrias ali existentes.

A Figura 119 mostra uma das passarelas na região da REPLAN, em Paulínia, na qual existem indústrias em ambos os lados da rodovia. Estas passarelas, próximas às áreas industriais, são utilizadas, quase que exclusivamente, por trabalhadores usuários de transporte público, que precisam atravessar a rodovia para tomar o ônibus de volta (ou de ida) para casa. Assim como no caso das passarelas próximas aos núcleos urbanos, o trecho viário sob a passarela é dividido por cercas que obrigam o pedestre a utilizar a passarela para travessia.

A localização das indústrias e o transporte coletivo metropolitano são de fato os principais elementos de indução na implantação das passarelas No caso mostrado pela Figura 120, ainda que não exista nenhum uso ou atividade em um dos lados da via, a grande quantidade de trabalhadores que são atraídos para esta área, em Paulínia, oriundos de Campinas e das cidades menores, justifica a implantação da passarela de travessia da SP332. O único atrativo da margem direita da rodovia é o ponto de ônibus localizado próximo à passarela, sempre lotado em horários de pico, em troca de turno das indústrias

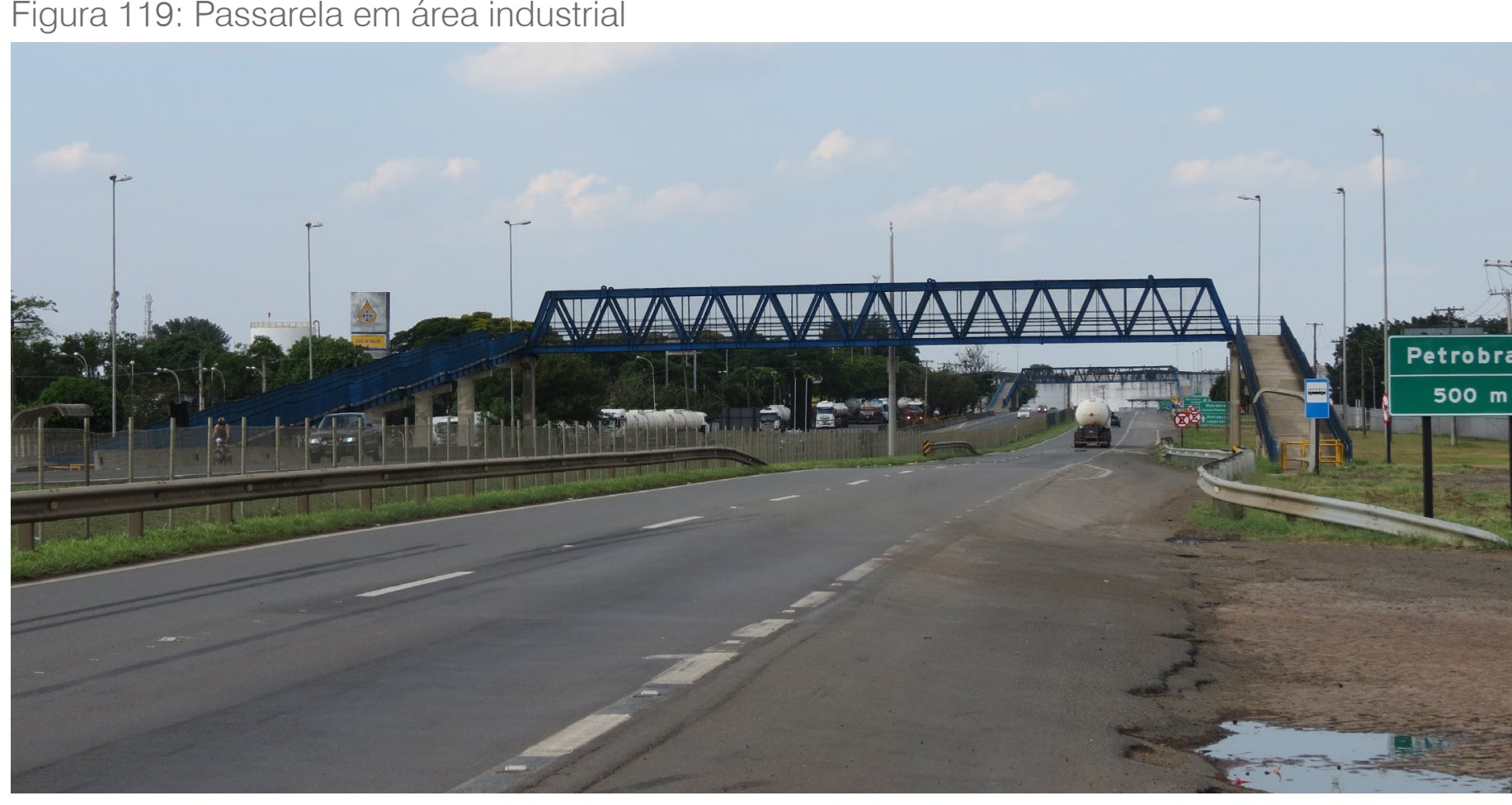

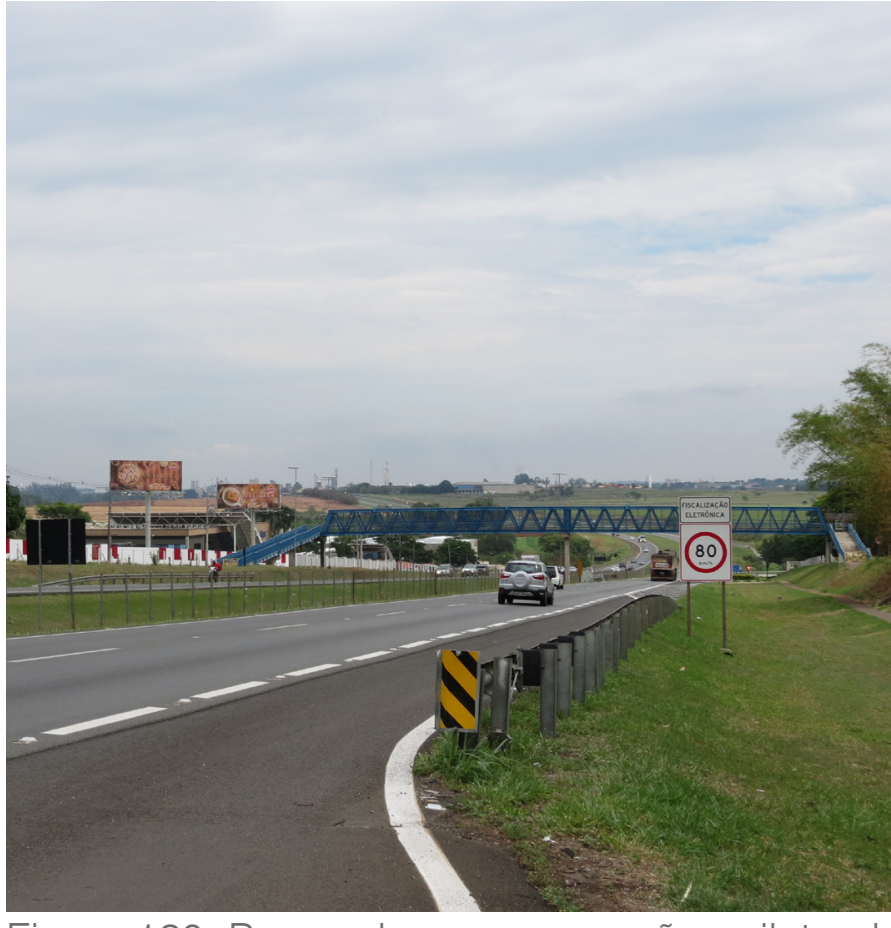

Figura 120: Passarela com ocupação unilateral

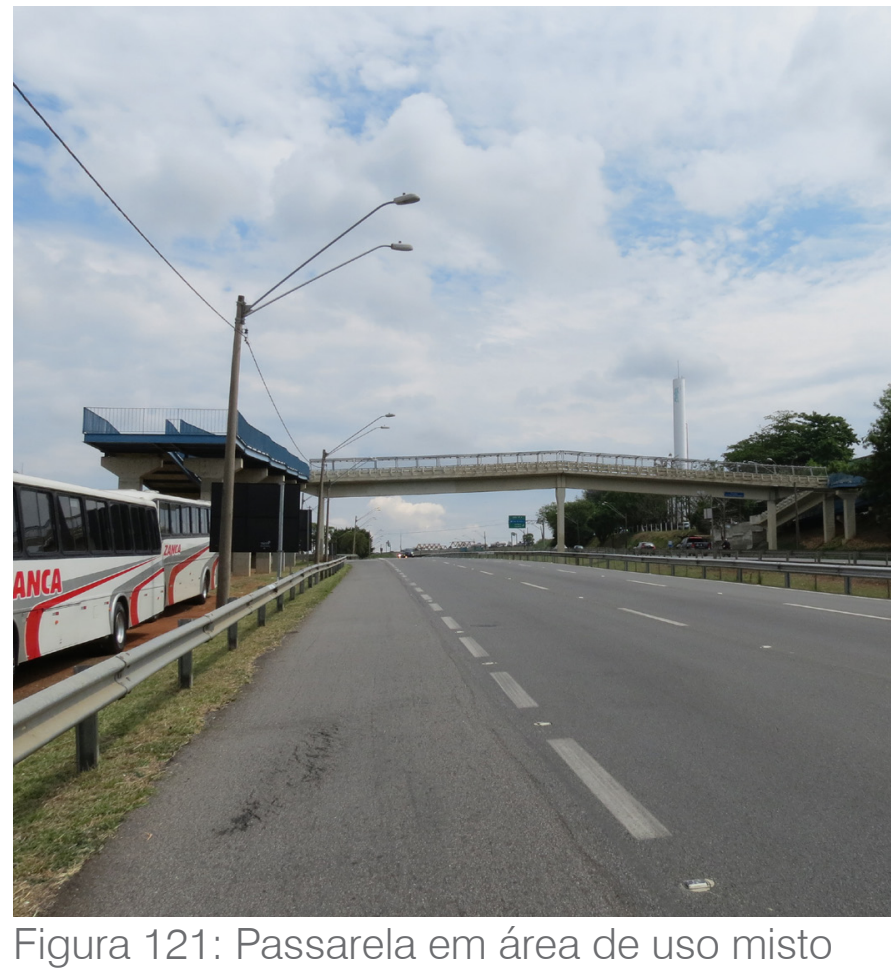


Os empreendimentos corporativos ou de serviços também se beneficiam das passarelas, como é o caso da passarela da Figura 121, no acesso à Campinas. De um lado, ocupação urbana, predominantemente residencial, com edifício corporativo. Do outro lado, ônibus fretados das empresas que se localizam nesta área ocupam sobra de viário da marginal da rodovia. Neste caso, não apenas o transporte coletivo se beneficia da passarela mas serve de elemento estruturador de todo o espaço.

Ainda que existam passarelas em locais estratégicos, como próximos às indústrias e núcleos urbanos, são diversos os trechos da Rodovia SP-332 que possuem população ocupando as áreas lindeiras e que necessitam transpor a rodovia. Ainda que as passarelas estejam localizadas próximas aos pontos de ônibus, o contrário não é verdade. Nem sempre os pontos de ônibus estão localizados próximos às passarelas, o que induz a travessia em nível pelos pedestres usuários de transporte público coletivo. Esse é o caso mostrado na Figura 122, que mostra um trecho da Rodovia SP-332, na cidade de Paulínia, em que há ponto de parada de ônibus em ambos os lados, mas não há formas próximas de travessia segura.

Outra situação a ser destacada em relação às travessias da rodovia é que, ainda que tenham sido colocadas cercas que barram a travessia de pedestres em nível, a falta de manutenção destes elementos permite que as pessoas ultrapassem os obstáculos para atravessar. No entanto é importante questionar a eficiência destas barreiras e das próprias passarelas como soluções para estes locais. Passarelas e barreiras muitas vezes impõem longos, desconfortáveis e perigosos percursos para os pedestres. Soluções tão ruins que muitos pedestres, como na Figura 123, arriscam suas vidas saltando barreiras e atravessando em locais perigosos. Quando os "acidentes" ocorrem culpa-se injustamente os pedestres.

Não apenas existem travessias de pedestres ocorrendo na rodovia, mas é possível observar a presença de ciclistas em áreas sem sinalização e que eventualmente também cruzam a rodovia, como mostrado na Figura 124, em trecho próximo ao distrito de Barão Geraldo.

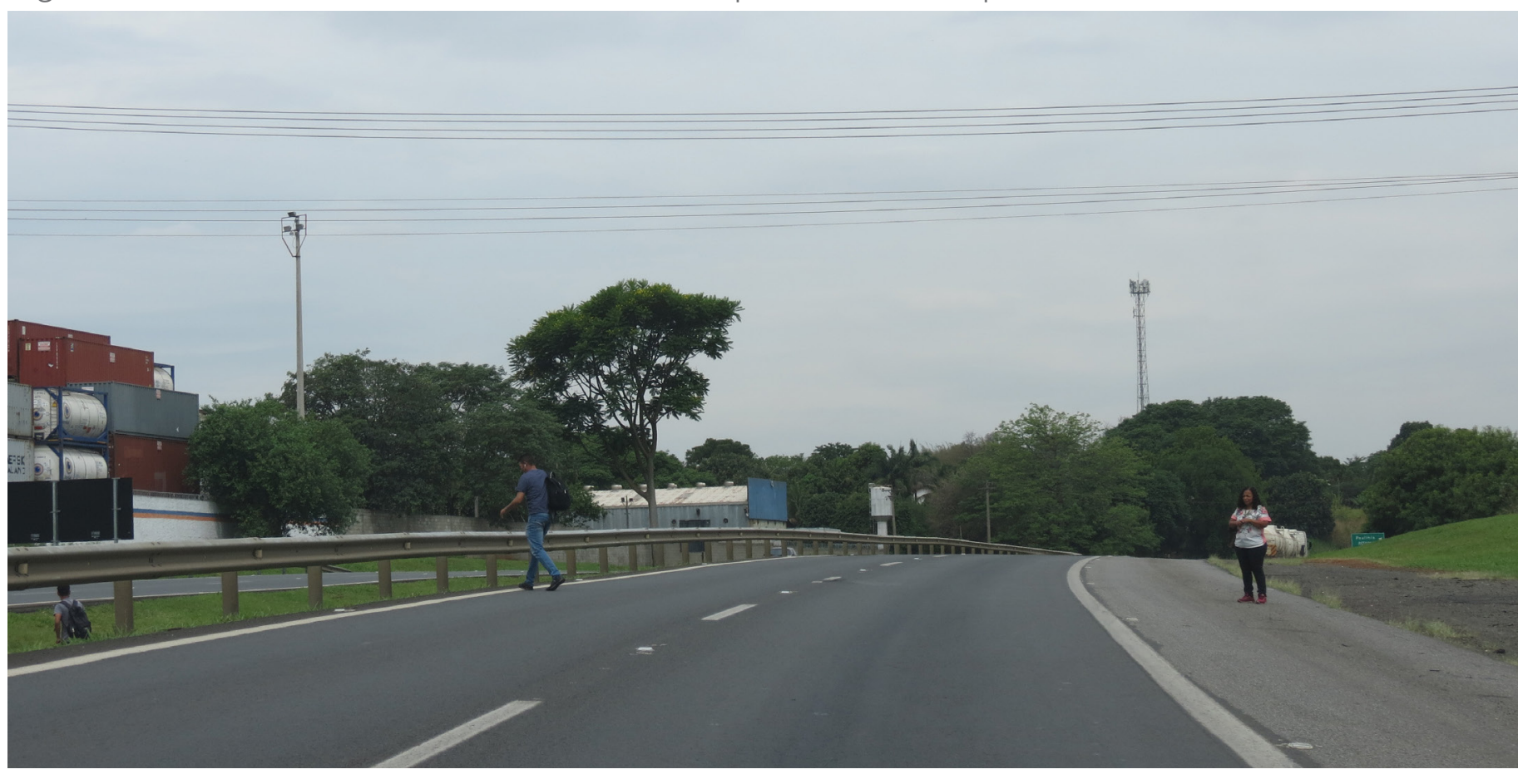

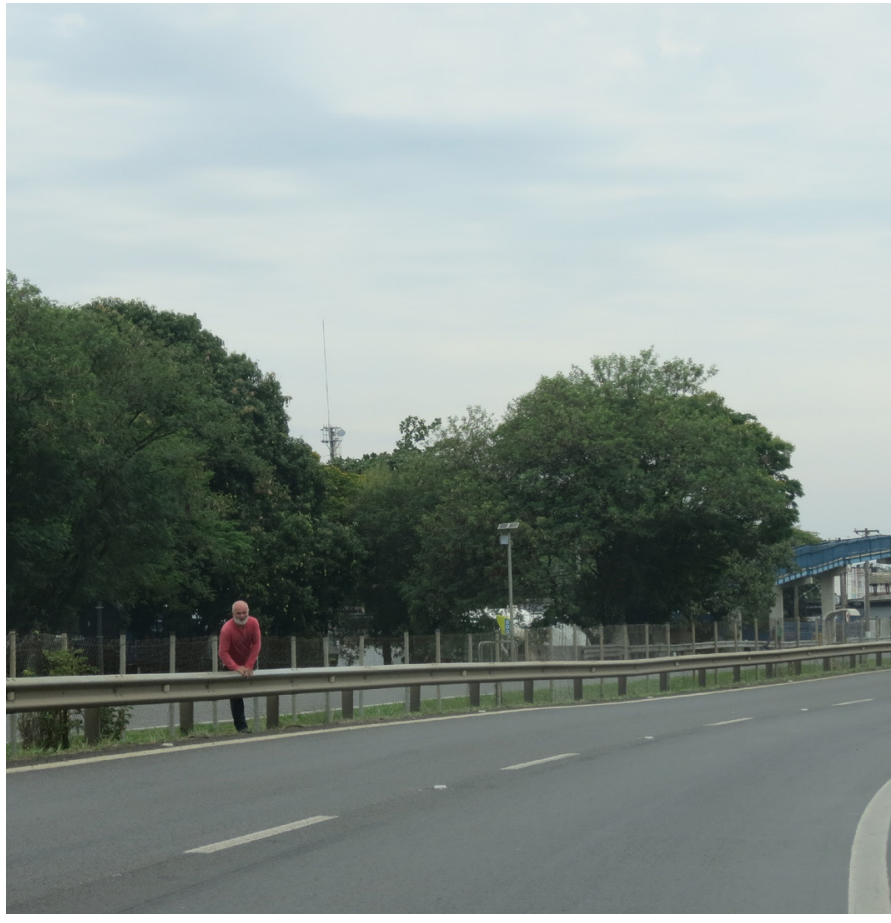

Figura 123: Barreiras sob as passarelas

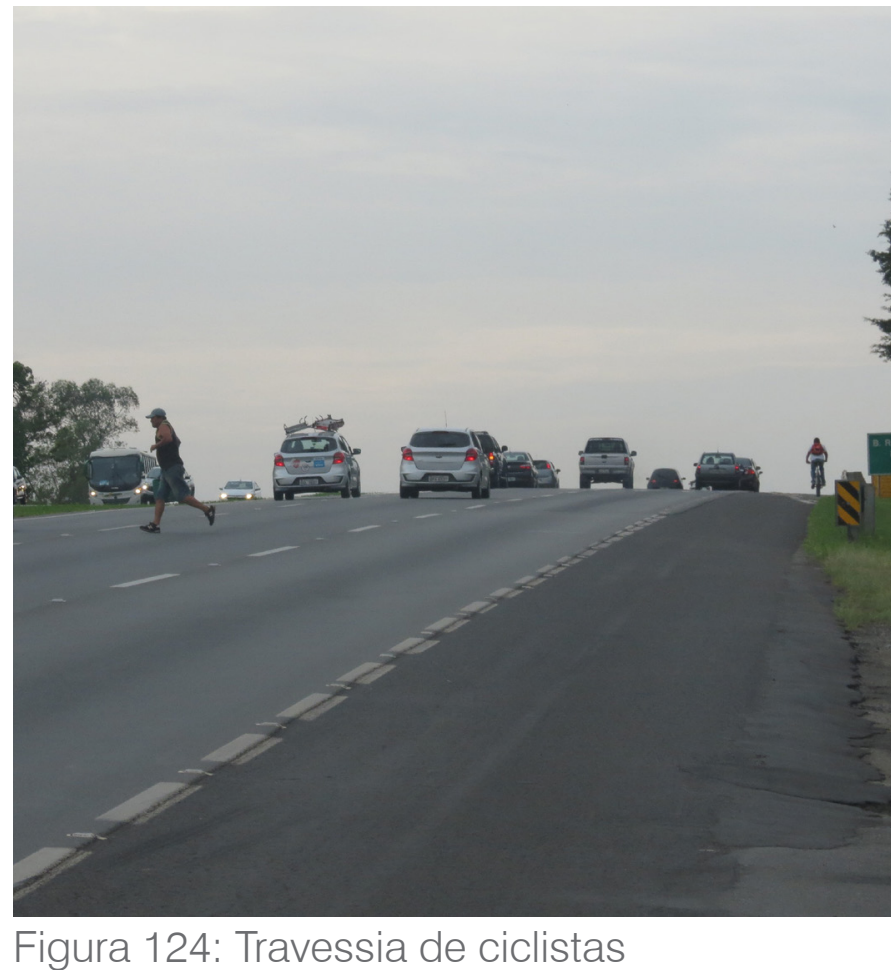


Nas estradas, vias metropolitanas, em áreas de menor fluxo de veículos que na Rodovia SP-332, o cenário padrão é a falta de sinalização e elementos que permitam a travessia segura do pedestre, que circula por essas vias Na maioria dos casos, não existe nem mesmo área de acostamento para os veículos, alternativa para a circulação de pedestres, como pode ser observado na Estrada Pref. Orlando Kiosia, em Cosmópolis, mostrado na Figura 125.

A mistura entre modais também representa o cenário das travessias nas vias metropolitanas. As vias marginais possuem fluxos de automóveis e caminhões, em locais de acesso às passarelas e pontos de ônibus A Figura 126 mostra uma mulher caminhando em direção ao ponto de ônibus da Rodovia SP-332, próximo ao distrito de Betel. No seu trajeto não há faixa de pedestres nem sinalização específica de travessia, apesar de ser um caminho reconhecido como necessário, visto que dá acesso ao ponto de ônibus da rodovia e há uma sinalização de pare, para os veículos que ali trafegam.

Já nos núcleos urbanos, principalmente na região central das cidades, como no caso de Paulínia, na Figura 127, as travessias são feitas guiadas por sinalização de trânsito, apresentando, ainda, infraestrutura para a circulação de pedestres. Nas cidades, pedestres e ciclistas encontram condições mais confortáveis e seguras para o convívio dos modais. No caso dos ciclistas, no entanto, a falta de uma via própria torna a travessia mais complicada, por compartilhar do espaço do pedestre, mas isso não a configura como insegura
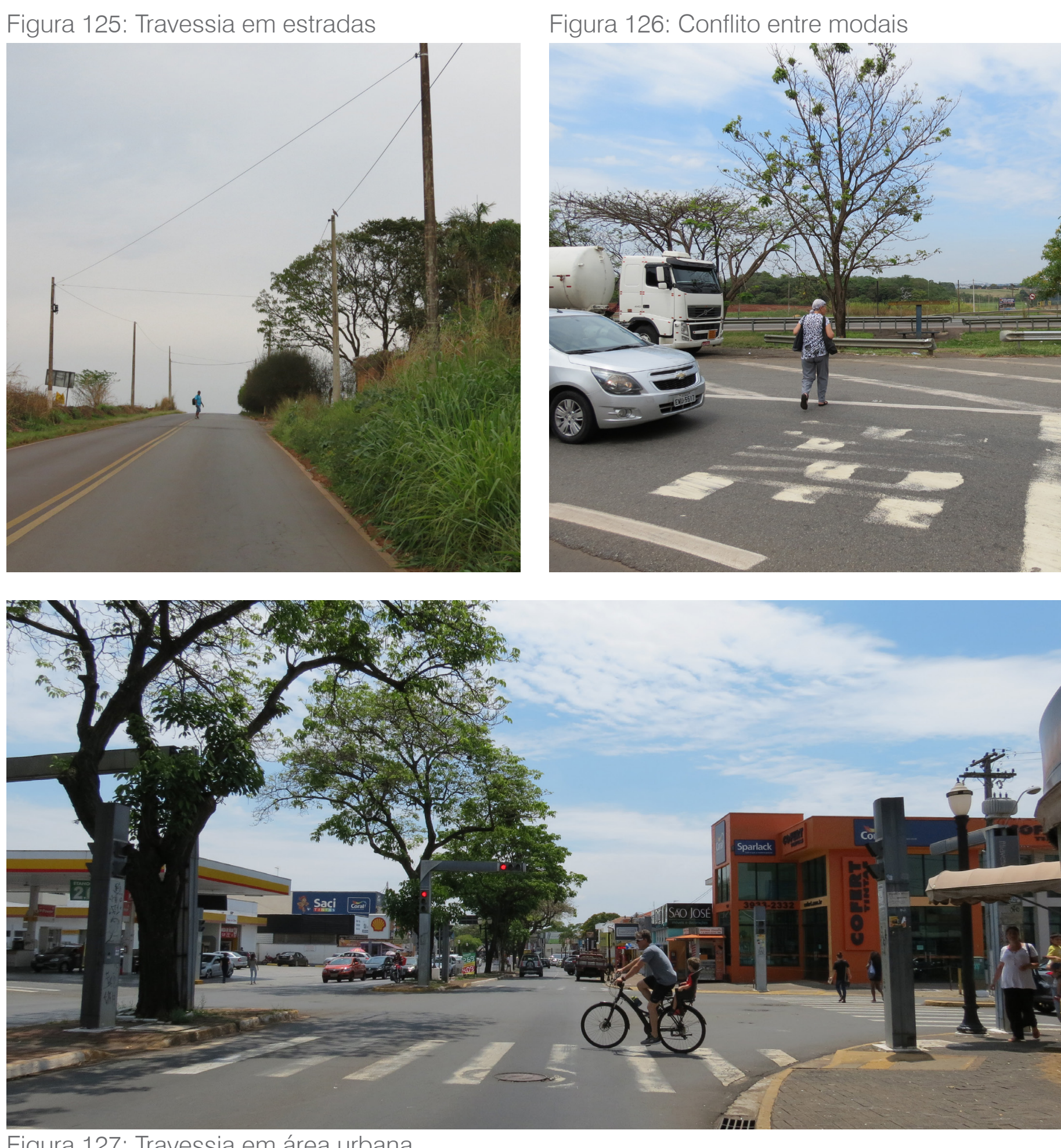

Figura 127: Travessia em área urbana 
CAPÍTULO 4

MANIFESTAÇÕES DA VIDA PÚBLICA NO SISTEMA VIÁRIO METROPOLITANO DO VETOR 3 

os núcleos urbanos consolidados e, de certa forma, adensados. Essas condições permitiriam a constância no deslocamento e a eficiência da via. O segundo gráfico, no entanto, representa a forma urbana do Vetor 3 da RMC, com ocupação urbana dispersa, que possui variadas proximidades com a rodovia, além da composição do sistema viário com vias que se cruzam e atravessam os núcleos urbanos consolidados. Isso gera diversidade de velocidades e condições específicas de trânsito para cada trecho das vias, exatamente o oposto do que se espera para as vias metropolitanas.

O terceiro gráfico adiciona, então, uma camada extra ao cenário do Vetor 3, destacando as áreas que não são consideradas no planejamento, construção e gestão da mobilidade da região e das cidades que a compõe. Os múltiplos movimentos internos, que podem ser realizados a pé ou bicicleta, além das permanências da população nos espaços do sistema viário, onde acontece a vida pública de quem ali habita, produzem, ainda mais, situações que conflitam com a classificação destas vias apenas como de caráter metropolitano.

A dispersão urbana, neste caso, é fator fundamental na compreensão da configuração dos espaços urbanos e metropolitanos. A baixa densidade das ocupações no território influencia diretamente nas suas dinâmicas, uma vez que induzem a população a se movimentar mais, para realizar atividades cotidianas. Essa condição define o modo de vida metropolitano, que se baseia nos múltiplos deslocamentos diários, aumentando as relações entre cidades e manchas de ocupação dispersas no território.

O espaço intraurbano é geralmente mais ocupado, mais denso e menos extenso que o espaço metropolitano, como pode ser observado na Figura 130, que representa um trecho do Vetor 3, na região de Paulínia próximo ao distrito de Betel. Ela mostra que o espaço urbano, localizado na marca dos $3 \mathrm{Km}$, é muito mais ocupado que os $10 \mathrm{Km}$ de um trecho metropolitano, ainda que possuam os mesmos tipos de ocupação. A localização das passarelas também revela essa diferença de escalas entre as áreas, com distância de travessia de aproximadamente $4 \mathrm{Km}$, enquanto no espaço

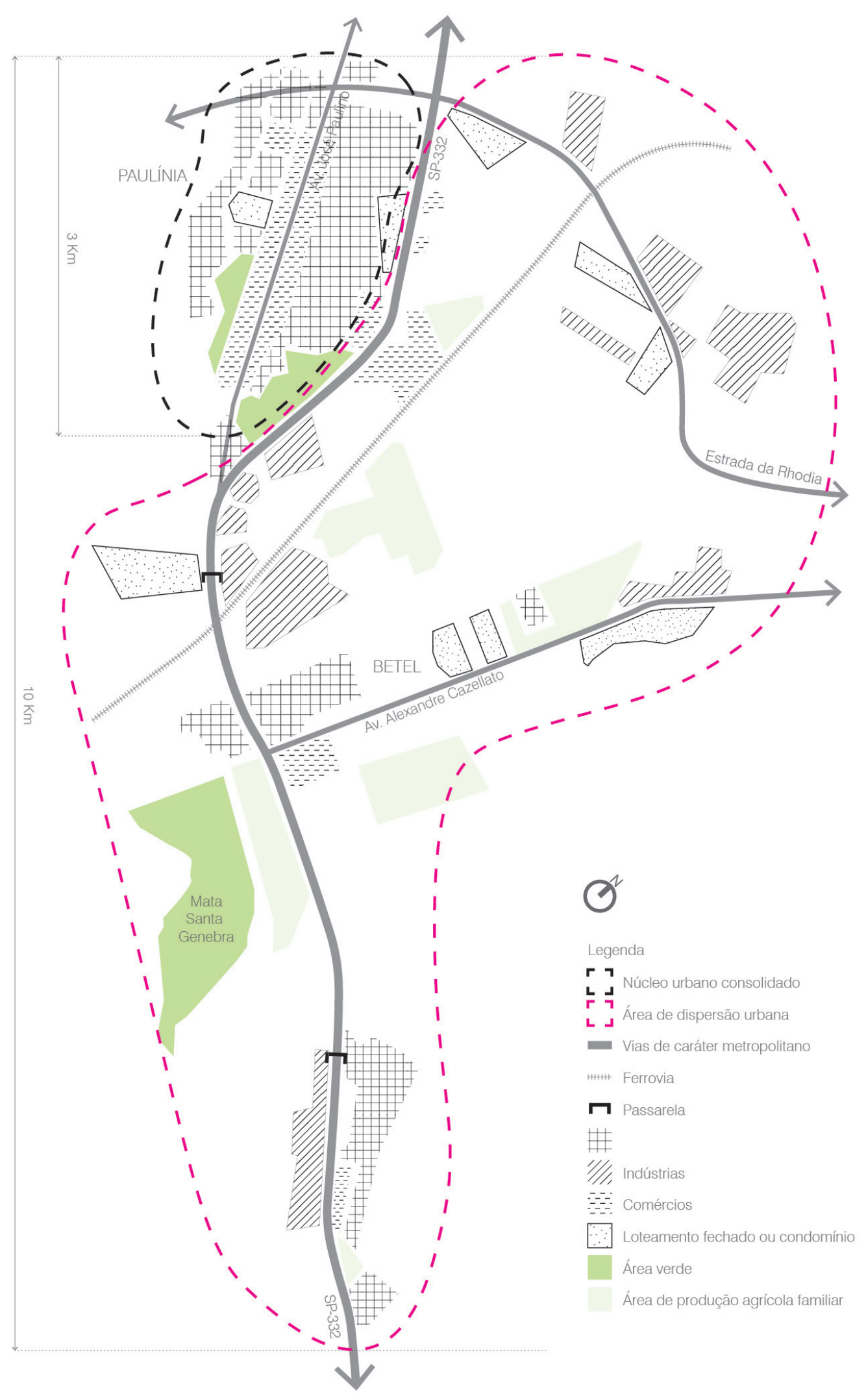


intraurbano, nas ruas, as travessias acontecem em todas as esquinas, em cada quadra.

A influência dessa diferença nas dinâmicas cotidianas é o que mostram a Figura 131 e Figura 132. Nessas imagens, foram representadas duas vias, baseadas em situações tipo, reconhecidas no desenho das seções viárias de aproximadamente 50 trechos do Vetor 3 da RMC, considerando as vias macro metropolitanas, metropolitanas e metropolitanas secundárias, conforme definido pelo SIVIM, apresentado no Capítulo 3.

Foram utilizadas, nas imagens, as condições médias das vias, para que fosse possível compará-las e compreender as relações existentes no território. A Figura 131 mostra uma via macro metropolitana, fora do núcleo urbano consolidado, com condições que a definem como rodovia. Já a Figura 132 mostra uma via metropolitana secundária, no interior do núcleo urbano consolidado, com condições similares a de uma rua.

A primeira observação que pode ser feita é que as vias são similares, quando se trata do espaço de circulação dos veículos. Ambas possuem duas faixas de circulação de veículos, sem grandes diferenças em largura, e contam com uma terceira faixa de serviços, utilizada como estacionamento na rua e como acostamento na rodovia. Outra similaridade é que nas duas existem pontos de ônibus, ainda que as condições de embarque e desembarque sejam distintas. Na rua, está localizado sobre a calçada pavimentada, enquanto na rodovia, está sobre os canteiros laterais, geralmente sem pavimentação.

Ainda que o espaço de circulação de veículos seja similar, os vários elementos que compõem as vias as diferenciam. O primeiro deles é o canteiro central, que possui diferenças nas suas dimensões, com maior largura na rodovia do que na rua

Além disso, as laterais das vias também são distintas. Enquanto na rodovia as laterais são ocupadas por canteiros com dimensões similares às do canteiro central (as vezes taludados), na rua estes espaços são ocupados por calçadas, para deslocamento dos pedestres. As condições das laterais da via também definem os elementos de segurança, representados na rodovia pelo guard rail e na rua pelas próprias guias das calçadas.

Outra diferença, conceitual, entre as vias, é que nas ruas existem vários cruzamentos em nível com outras ruas, ao contrário das rodovias, onde os cruzamentos são em desnível. Essa característica define as possibilidades de travessias, que nas ruas podem ser realizadas nas faixas de pedestres, semaforizadas ou não, enquanto nas rodovias deveriam ser realizadas apenas nas passarelas, localizadas em trechos estratégicos, mas distantes umas das outras. Ainda que as ruas ofereçam locais de travessia bem definidos, principalmente junto aos cruzamentos, é comum que sejam atravessadas em pontos variados, expondo os pedestres aos riscos de acidentes, tanto quanto nas rodovias. No entanto, quanto maior a velocidade e maiores os veículos, maior a gravidade dos acidentes, sendo as consequências mais graves e letais nas rodovias.

Em relação à arborização, apesar de nas ruas ser escassa, nas rodovias essa condição é ainda mais precária, sendo praticamente inexistente. Da mesma forma acontece com o mobiliário, como lixeiras e bancos. Já a iluminação está presente de forma regular nas ruas, mas só existe em pontos específicos nas rodovias.

Além de ilustrar as condições gerais das vias, as imagens possuem representações das ocupações presentes nos cenários de cada uma Nota-se que foram reconhecidas, em campo, as mesmas ocupações em ambas as vias. Do lado esquerdo das imagens, foram localizadas as ocupações que não possuem distinção na sua relação com a rua ou com a rodovia. É o caso dos condomínios, horizontais e verticais, que possuem muros de divisa independente de sua localização no espaço urbano ou metropolitano; dos comércios e serviços, que na maior parte das vezes têm sua testada de franco acesso, com recuos tomados pelos estacionamentos de veículos; as chácaras, que possuem acesso po caminhos secundários, dificilmente com acesso direto às vias; os vazios, que se assemelham tanto na rua quanto na rodovia, por serem espaços livres de uso, geralmente cercados; e as ocupações agrícolas familiares, 


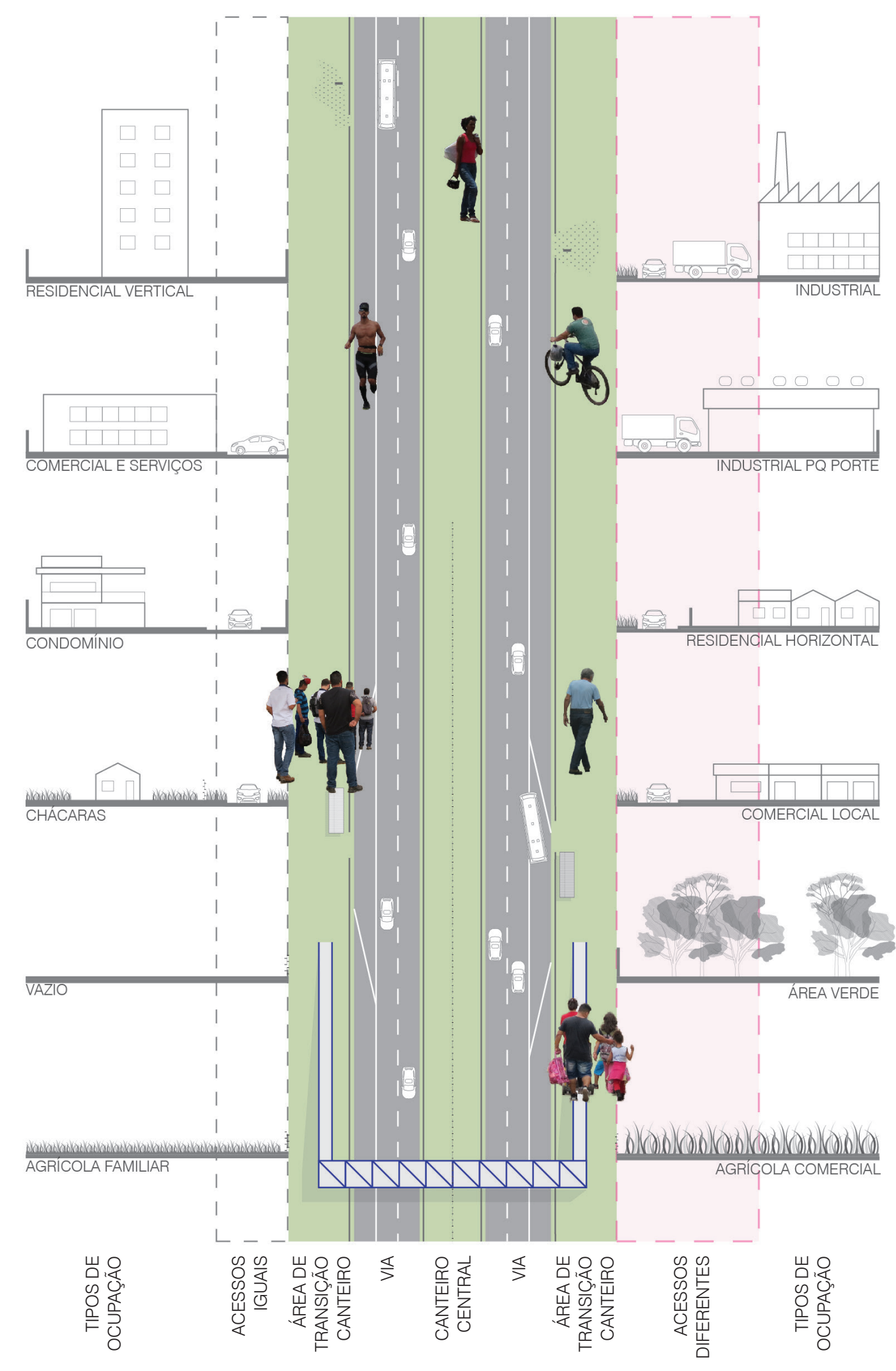

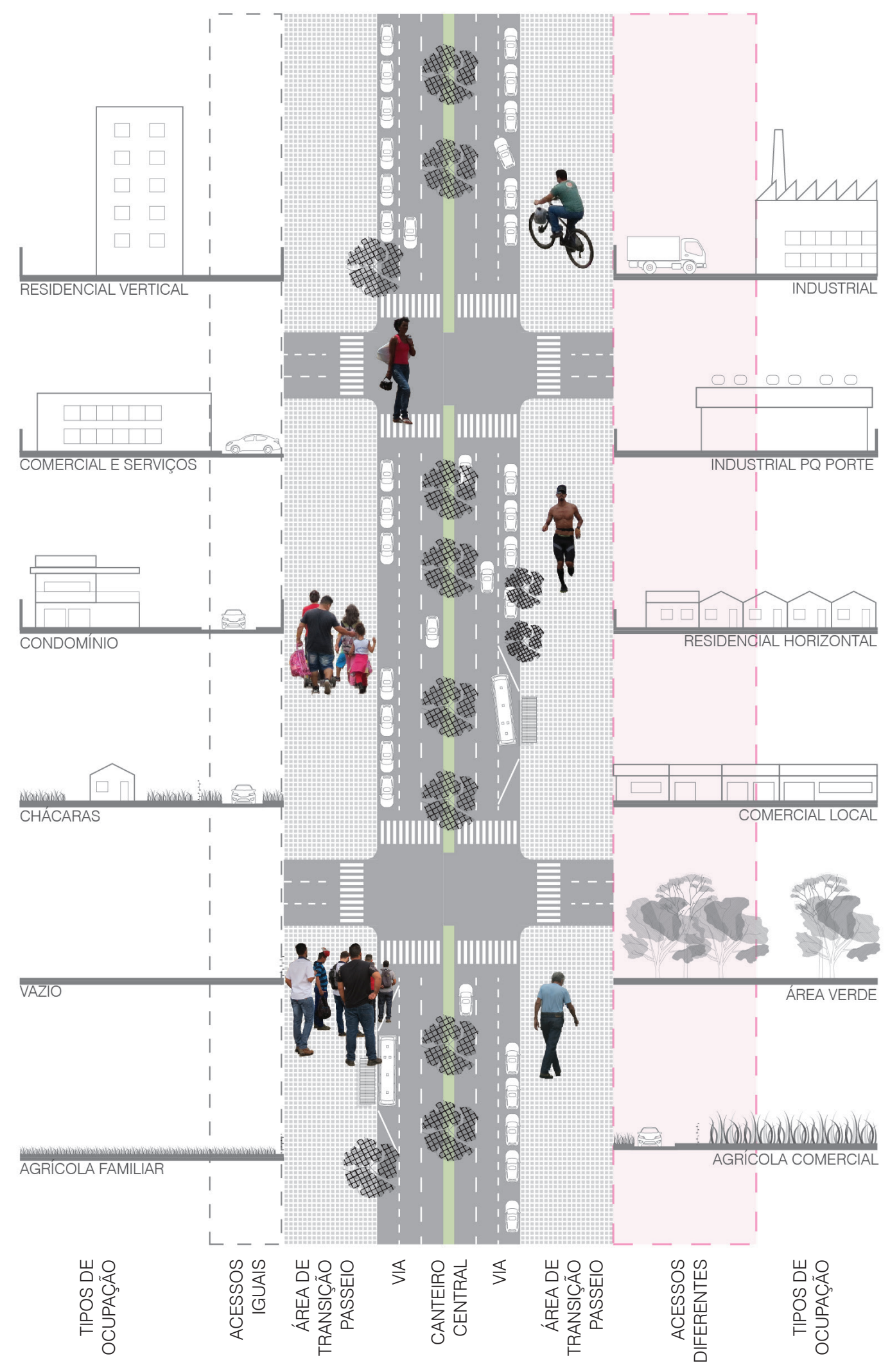


que possuem relações diretas com ambos os cenários, separados apenas por cercas, que as delimitam.

Do lado direito, foram posicionadas as ocupações que, apesar de serem semelhantes em ambos os casos, possuem relações distintas com a via. É o caso das indústrias, que na rodovia geralmente são acessadas por vias marginais ou acessos viários, com estacionamento de caminhões em área livre. Nas ruas, as indústrias geralmente estão cercadas, sendo que apresentam acesso direto às vias e pátios de caminhões internos aos lotes. As mesmas condições podem ser observadas nas indústrias de pequeno porte.

Para as áreas residenciais, nas rodovias seus acessos geralmente ocorrem por vias marginais, separadas, por canteiro, do fluxo de alta velocidade. Já nas ruas, o acesso geralmente é direto, muitas vezes com recuos frontais Para o comércio local, a situação se repete, mas nas ruas os acessos geralmente são diretos

As áreas verdes, como praças e parques, também possuem diferenças na sua condição entre rodovias e ruas. Nas rodovias, geralmente são espaços de proteção ambiental, com arborização e vegetação densa próximos aos rios, cercados, com dificuldade de acesso, sem relação direta com as rodovias. Nas áreas próximas às rodovias, essas áreas são, muitas vezes, caracterizadas como simples gramados com árvores e palmeiras plantadas, aparentemente, sem critérios. Nas ruas, as áreas verdes geralmente são as praças, que são abertas às pessoas, podendo ser espaços de permanência dos pedestres.

E, por último, as relações das áreas de agricultura comercial, que possuem acesso direto às rodovias, mas nas ruas geralmente são acessadas por vias marginais, sem acesso direto.

Contudo, diante deste cenário, fica evidenciado que as principais relações entre as vias e as ocupações são as conexões que se estabelecem na interseção das áreas lindeiras com os espaços de permanência das vias, pois são nestes lugares que a vida pública acontece.

Na comparação mostrada nas Figuras 133 e 134, é possível ver que as ruas no espaço intraurbano, possuem elementos que permitem a permanência, além de permitirem as passagens e os acessos das pessoas. Isso inclui as áreas verdes, que na rua são abertas, como é o caso das praças. Nas vias macrometropolitanas, as rodovias, por sua vez, não existem esses espaços, com exceção das passarelas e pontos de ônibus, o que levaria a crer que não existiria vida pública nesses lugares. Essa situação é agravada pela falta de integração destes elementos da rodovia com o restante do espaço em que se inserem, já que estão ilhados em áreas sem infraestrutura adequada para a circulação e permanência das pessoas.

Aa figuras destacam esses espaços, aptos a abrigar as atividades de importância local, de apropriação do espaço e estabelecimento de relações de vizinhança e comunidade. O posicionamento das imagens de pedestres e ciclistas, nestas figuras, foi realizado de forma a representar algumas situações encontradas na caracterização do Vetor 3.

Figura 133: Manchas de ocupação dos Dedestres na rodovia

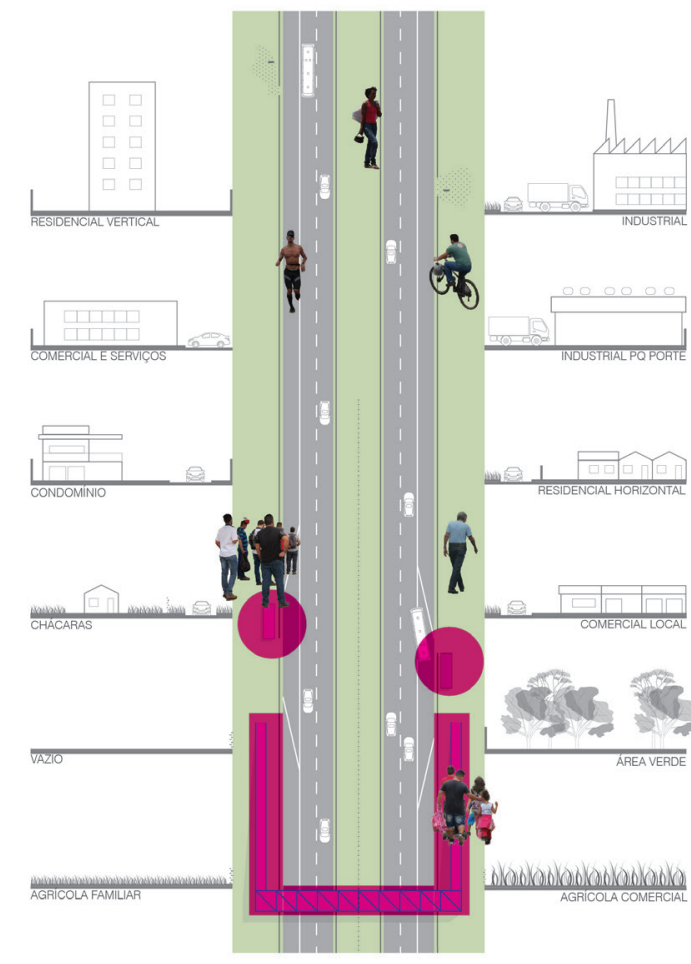

Fonte: Elaborado pelo autor
Figura 134: Manchas de ocupação dos pedestres na rua

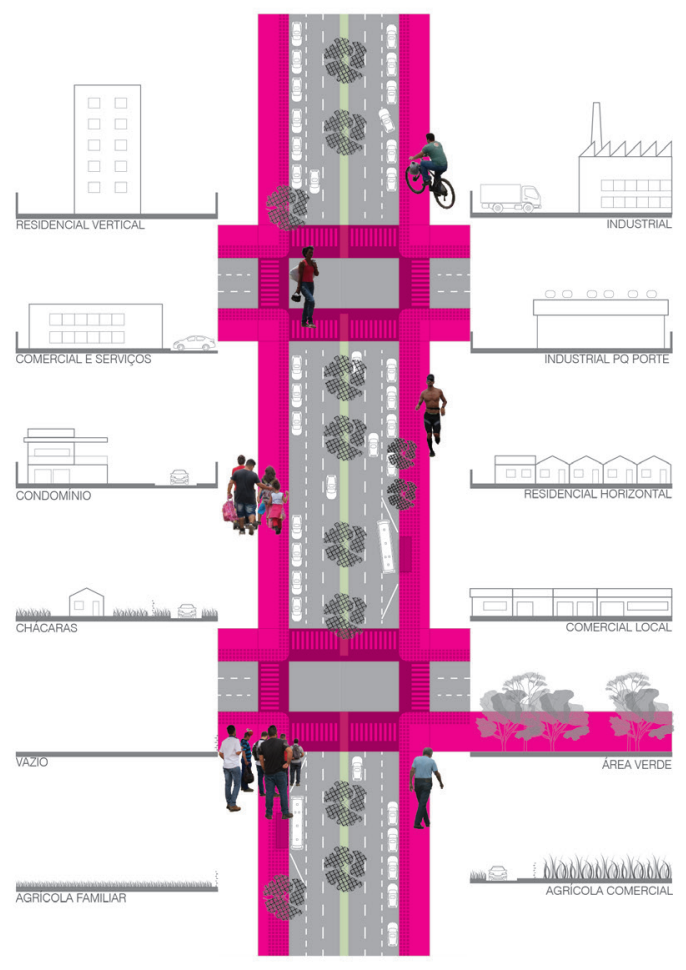


Além dessas situações, com predominância das dinâmicas de deslocamento, foram encontrados em campo algumas situações que mostram que a vida pública nos espaços da mobilidade é mais complexa e está presente, ainda que os espaços não sejam adequados.

As imagens a seguir mostram atividades que ocorrem fora dos lugares esperados, além das contradições encontradas entre o modo de vida metropolitano, que se mistura com os modos de vida urbano e rural e os espaços disponíveis para que eles aconteçam

A brincadeira das crianças no acostamento da rodovia SP-332, mostrado na Figura 135, é uma das cenas que mais chama a atenção, já que mostra claramente a mistura entre os tempos da metrópole. Moradores da área residencial mostrada ao fundo, separada da rodovia por área arborizada o lugar se transforma em uma praça e o guard rail se transforma em banco ou brinquedo de subir, de onde podem ser observados os automóveis em alta velocidade.

Esta mesma sobreposição, a mistura entre tempos e velocidades pode ser notada na Figura 136, que mostra duas mulheres conversando tranquilamente no ponto de ônibus localizado na rodovia SP-332. O que é interessante nesta imagem é o posicionamento de uma delas, que se encontra do lado de fora da proteção, em uma posição que parece confortável, sem se importar com o movimento em alta velocidade que acontece às suas costas. Apesar de elas estarem conversando ali, a infraestrutura disponível no local é toda voltada ao automóvel ou ao ônibus que se utilizam da rodovia, com exceção da passarela.

Os pontos de ônibus são os lugares da rodovia que mais abrigam dinâmicas contrastantes em relação às velocidades. Neles, além da espera diária pelo ônibus, dos encontros, permanências e trocas cotidianos, também acontecem momentos importantes na vida familiar, como mostra a Figura 137. Em um domingo à tarde uma família se reúne para a despedida de algum deles, que carrega uma mala grande de viagem. O automóvel estacionado e uma bicicleta encostada no ponto de ônibus mostram que

Figura 135: A brincadeira

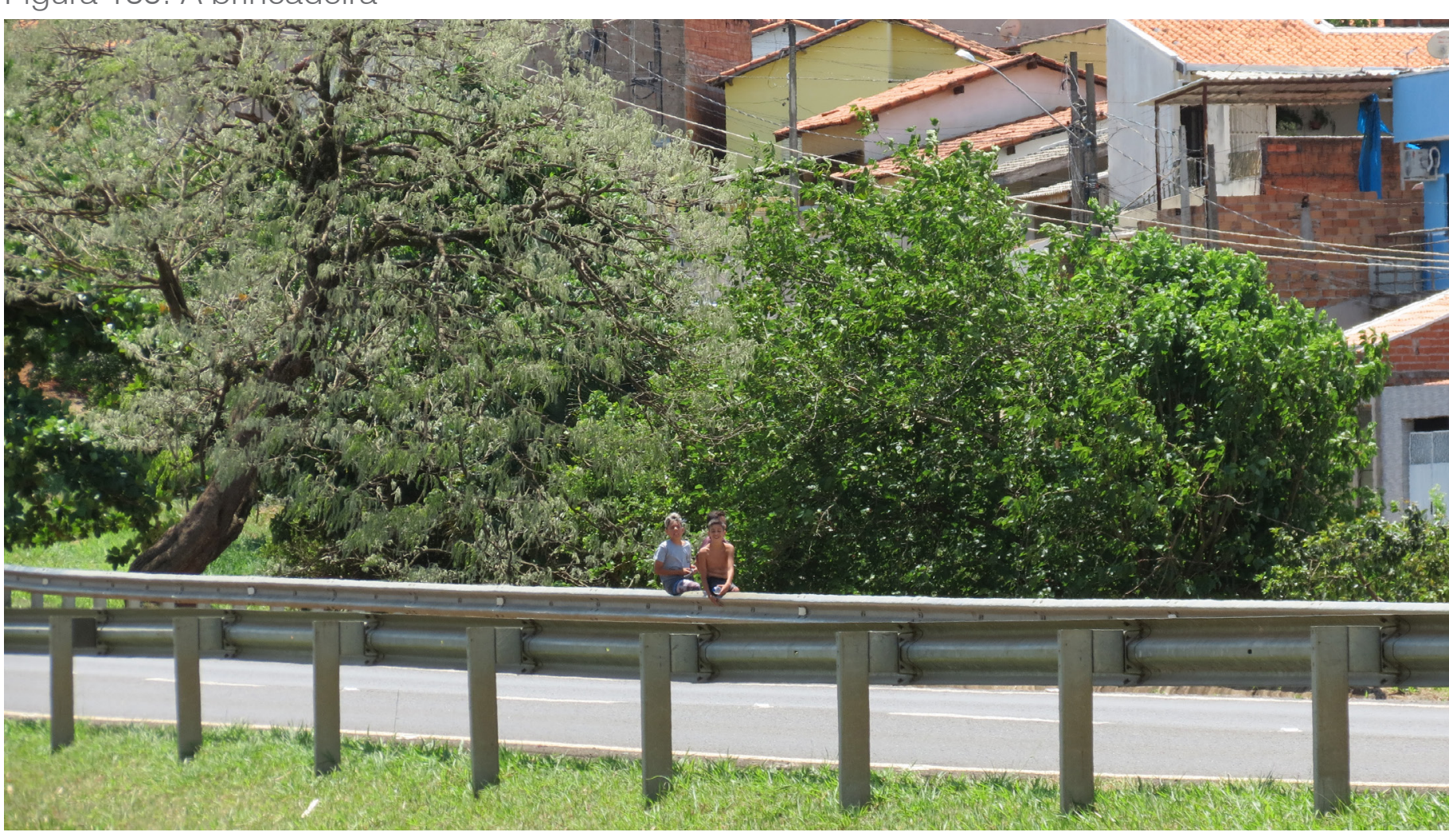

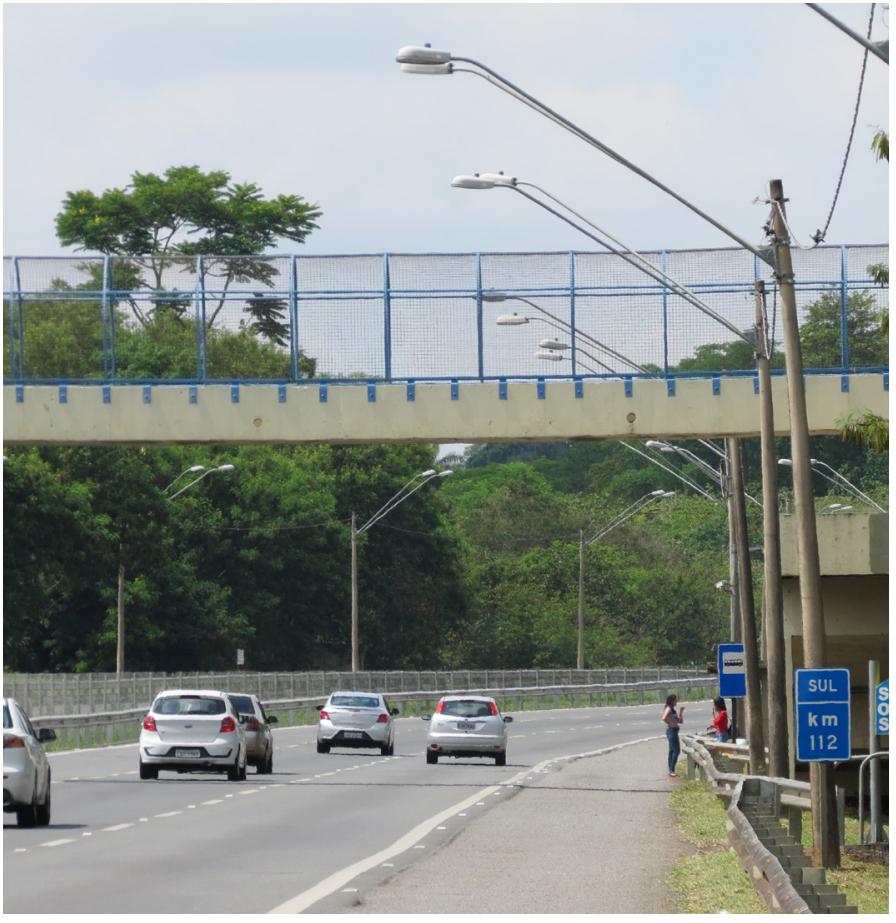

Figura 136: O bate papo

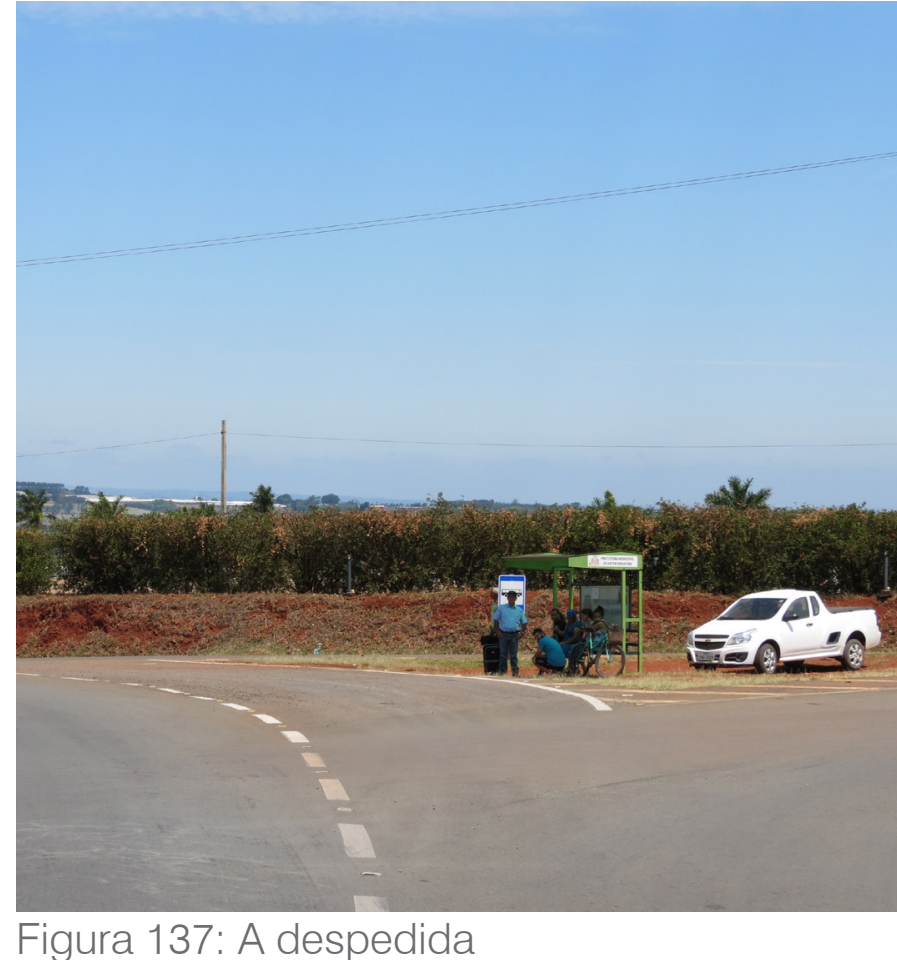


toda a família se deslocou até o ponto de ônibus para a despedida, visto que estão em sete pessoas. Além disso, a bicicleta revela que essas pessoas habitam área próxima à rodovia, ou a estrada vicinal de Cosmópolis, em distância suficiente para o deslocamento por bicicleta até o local.

Vale lembrar que as cidades menores do Vetor 3 dependem de Campinas para as viagens maiores, seja pelos ônibus do terminal rodoviário ou pelo Aeroporto de Viracopos. Mas o que cabe destacar aqui, é que o ponto de ônibus se tornou um espaço familiar, de despedida e de reunião, e não parte apenas da viagem, da relação com os meios de transporte. A transescalaridade da metrópole pode ser, assim, percebida nesta imagem pelo conjunto das dinâmicas locais, de confraternização da família, e da dinâmica global, da viagem a ser realizada, em longa distância, que se desenvolvem sobre o mesmo lugar.

Mas não é apenas pela questão física que as escalas se relacionam nos espaços metropolitanos. Na Figura 138 é possível ver, junto com os trabalhadores que estão presentes ali, um anúncio de "internet rural" em uma das placas. A vida pública da população que habita as áreas de dispersão urbana também acontece pelos meios de comunicação. Ou seja, ao contrário do imaginário que se tem do habitante das áreas rurais isolado das dinâmicas regionais e globais, deve ser superado da mesma forma que deve ser superada a ideia de que a vida pública não tem lugar nos espaços da mobilidade metropolitana.

Essa imagem, ao mesmo tempo que mostra a possibilidade de conexão da população rural com o restante da região metropolitana pela comunicação, mostra que os lugares da vida pública nessas áreas são improvisados, como é possível perceber pelo banco onde o homem está sentado e onde está localizado. O acesso à uma via de terra, quando as pessoas se encontram, ou param para descansar, vira uma praça. Essa situação explicita o que Queiroga (2012) chama de "pracialidade", definido a partir do reconhecimento de que as ações que caracterizavam as praças públicas, sejam elas convívio, encontro e manifestações públicas, não se estabelecem nestes lugares de forma exclusiva, mas podem se desenvolve

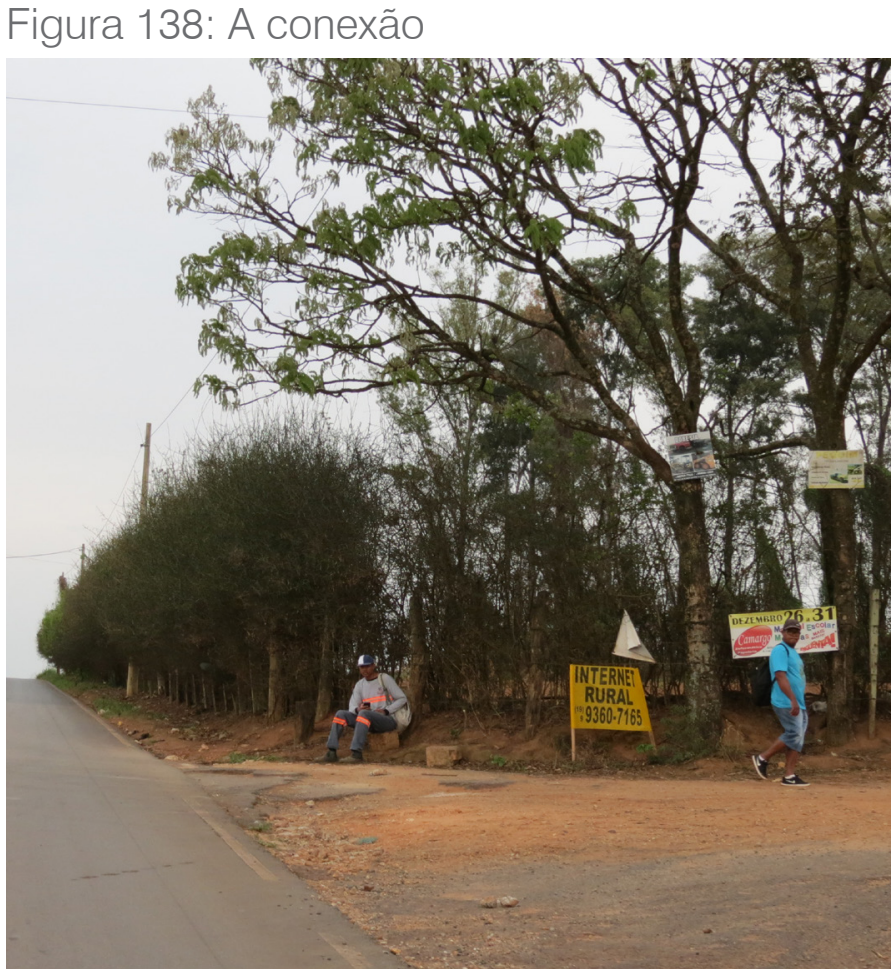

Figura 139: A praça

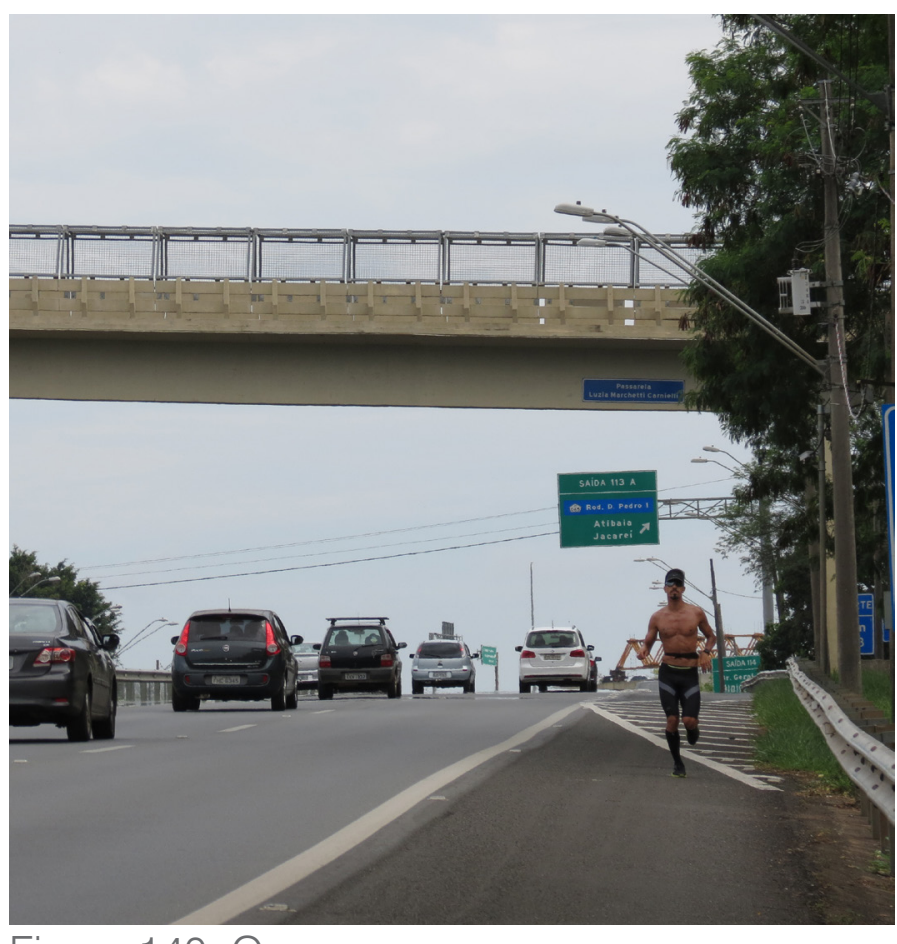

Figura 140: O parque

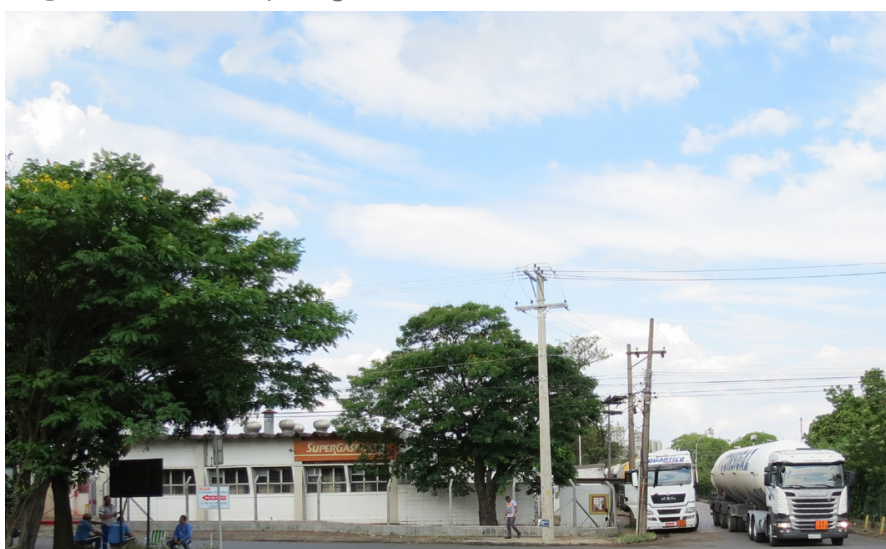

the
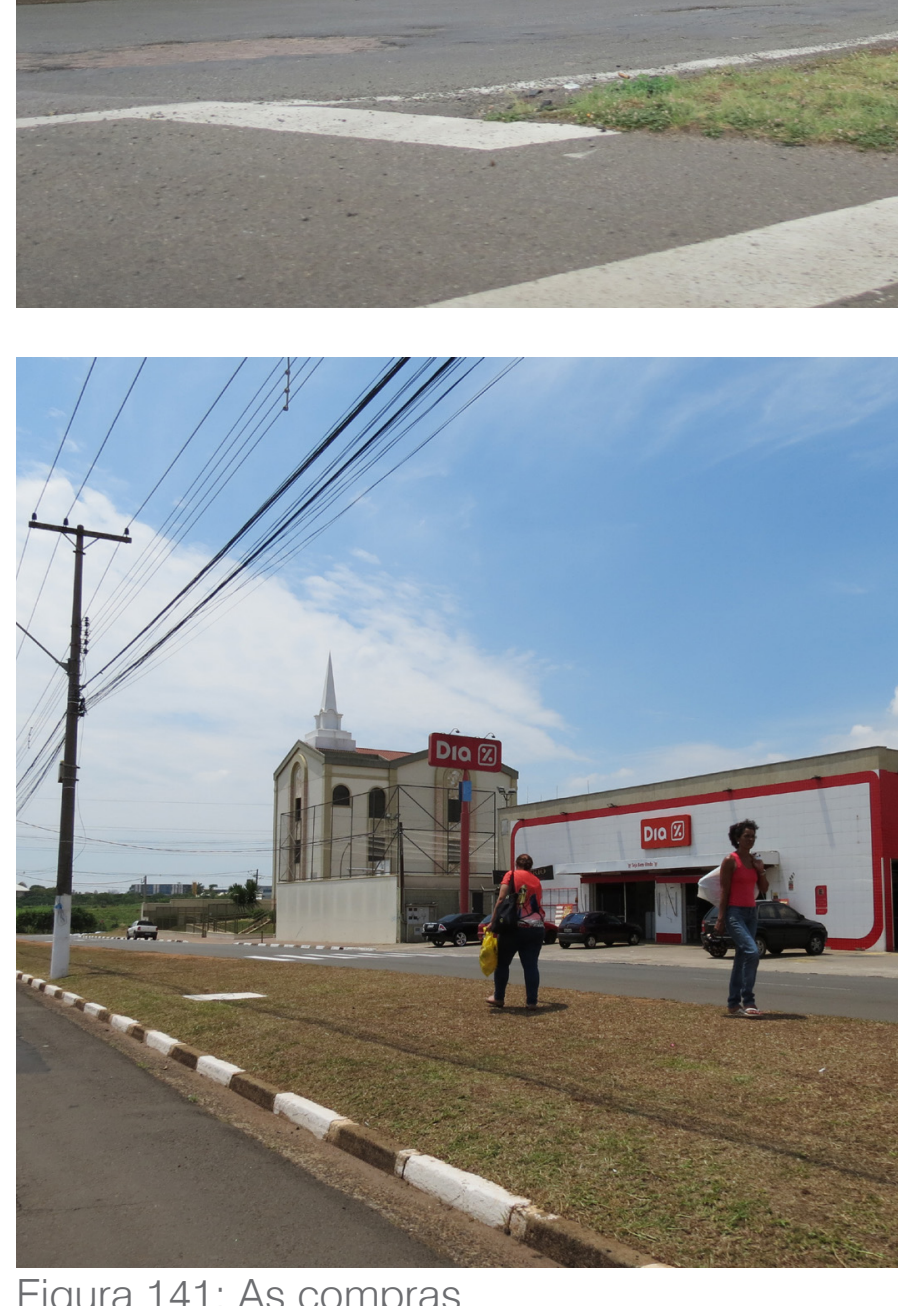

Figura 141: As compras 
nos mais diferentes contextos urbanos, e metropolitanos, como é o caso aqui, onde sejam propícias as manifestações da vida pública.

Essa mesma lógica pode ser aplicada à Figura 139. Ela mostra uma roda de conversa composta por trabalhadores das indústrias, que podem ser observadas ao fundo. Eles estão sentados em cadeiras de plástico colocadas sob a sombra de uma árvore, em local gramado. A cena que poderia acontecer em qualquer praça, está localizada em uma área remanescente do sistema viário, em via marginal com saída direta para a rodovia SP-332

Mas não é só a praça que encontra lugar no sistema viário metropolitano. A Figura 140 mostra um homem praticando corrida no acostamento da rodovia SP-332, como se estivesse em uma rua ou em um parque. Seu trajeto estava localizado em trecho entre Campinas e Paulínia e o circuito da corrida compreendia os dois lados da rodovia, com passagem pela passarela. É importante notar que não existe no local nenhuma estrutura com exceção da própria passarela, para o deslocamento a pé, nem por motivos de lazer, nem por outros motivos cotidianos, como a ida ao trabalho

E essa condição pode ser observada não apenas nas vias macro metropolitanas, nas rodovias. Nas vias metropolitanas secundárias, que possuem maior relação com os núcleos urbanos consolidados, a falta de infraestrutura para a circulação dos pedestres também é uma realidade. A Figura 141 mostra duas mulheres que foram às compras se deslocando pela via, no canteiro central, sem pavimentação. Importante notar a presença de um grande mercado e de uma igreja ao fundo da imagem, além de áreas livres de ocupação. Esses equipamentos, ainda que sejam de grande atração de pessoas, têm formas e implantações que se relacionam muito mais com a dinâmica dos transportes motorizados que da mobilidade a pé

Ainda assim, é importante ressaltar que a presença dessas mulheres, ainda que estejam em deslocamento, configuram a permanência nestas

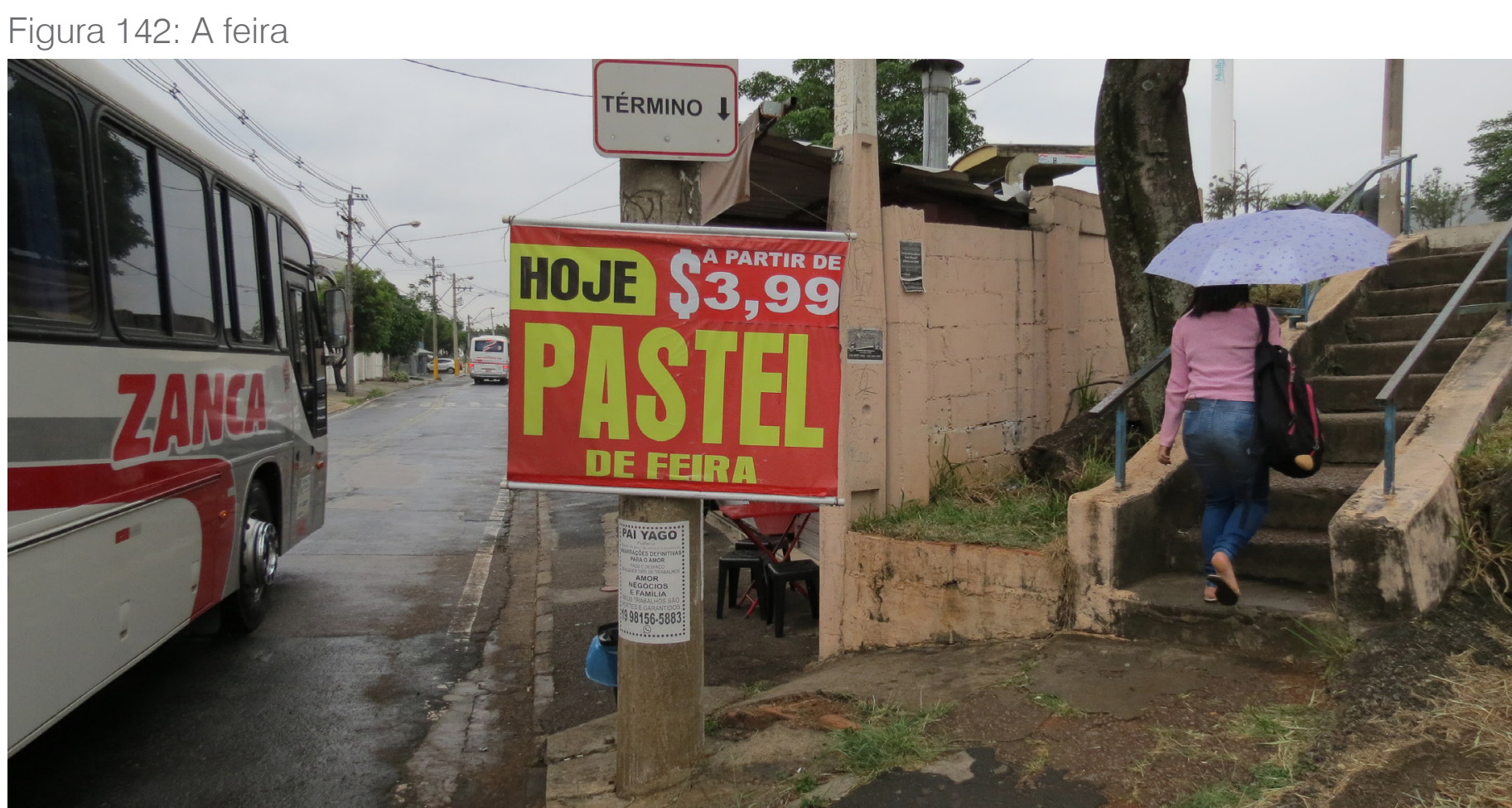

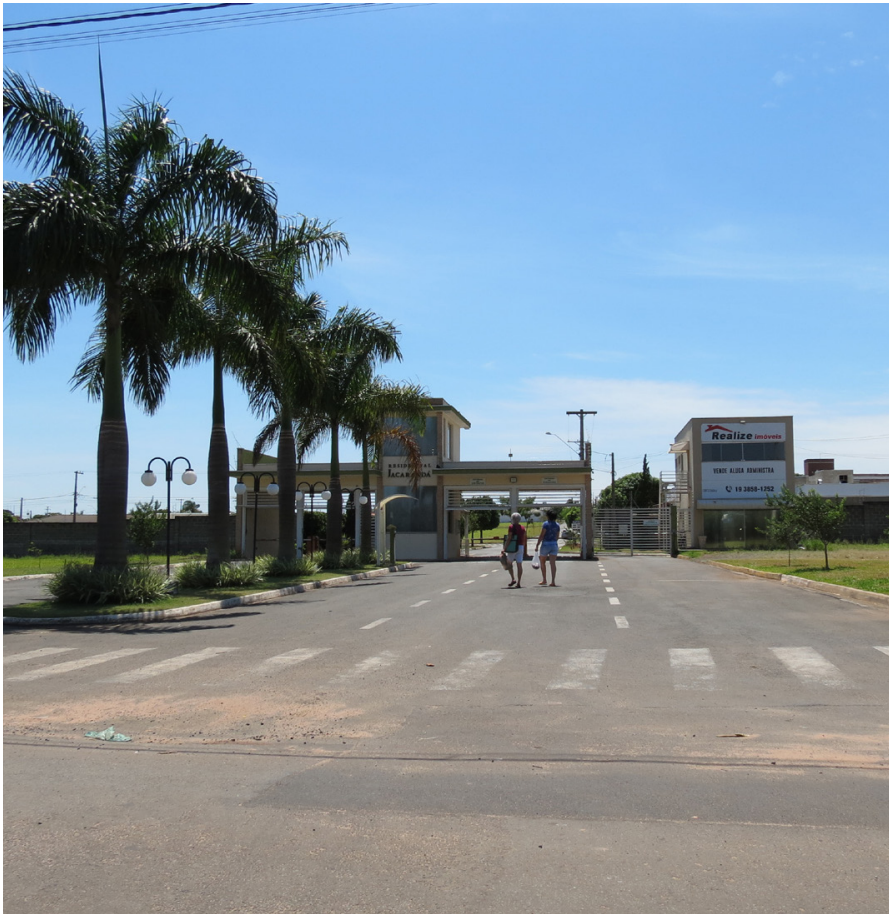

Figura 143: O passeio

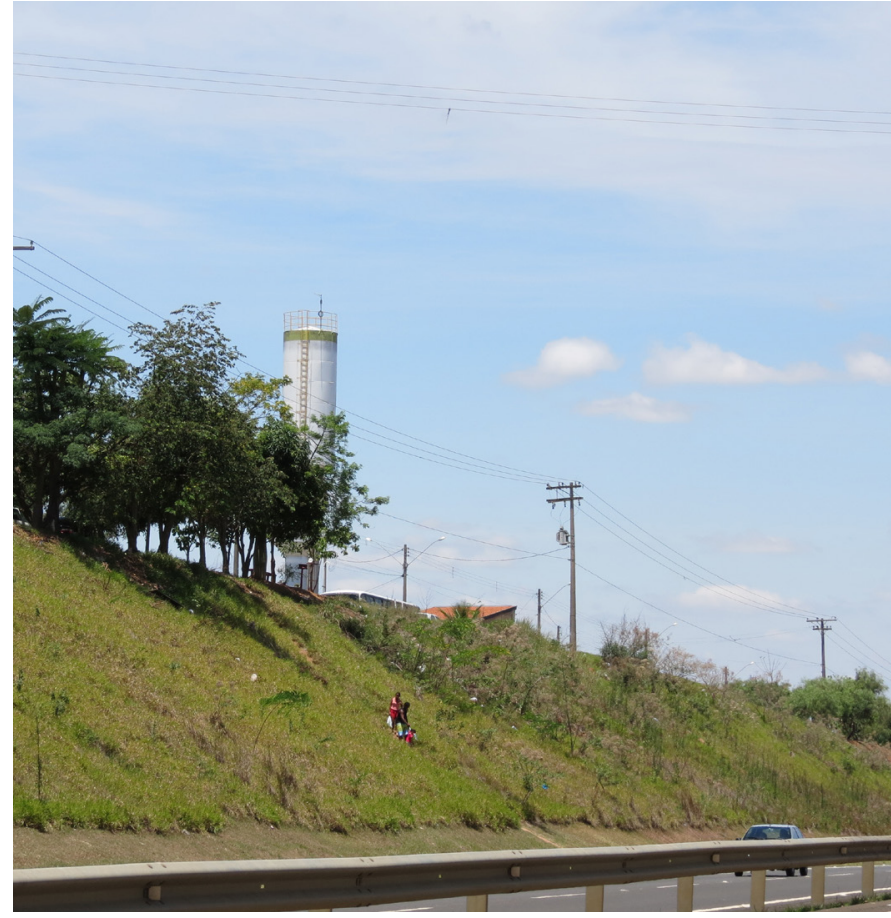

Figura 144: O caminho 
áreas, principalmente pelo contraste entre velocidades presentes no local. O que para o automóvel é apenas o canteiro central de separação de vias, para elas é a possibilidade de ocupação do espaço e de acesso às compras.

O comércio, que tem grande potencial de atração e concentração de pessoas também ocorre em locais inesperados da metrópole. Na Figura 142, uma barraca de pastel, típica das feiras urbanas, foi instalada próxima ao ponto de ônibus da SP-332, em via marginal que dá acesso a diversas indústrias na área. Importante notar que ainda que essas atividades aconteçam ali e que reúnam diversas pessoas, os espaços para os pedestres são escassos e mal construídos. A escada é pequena e a calçada é estreita, enquanto a via marginal por onde circulam os ônibus fretados é larga e bem conservada. A existência da pastelaria mais do que reunir pessoas, ou criar oportunidades de convívio e encontros, é a prova de que o lugar é frequentado diariamente por tantas pessoas que sustentam a atividade naquele lugar.

Ainda que estrutura para que a vida pública aconteça nas áreas de dispersão urbana e nas vias metropolitanas seja praticamente inexistente, como foi apontado anteriormente, as dinâmicas da população não deixam de existir. A Figura 143 mostra o passeio de duas moradoras de um condomínio em Engenheiro Coelho. Ainda que o condomínio seja a representação da segregação e da vida apenas entre iguais, é possível notar que muitas pessoas se utilizam dos espaços externos aos muros como lugar de passeio. Na imagem, as mulheres utilizam o espaço destinado ao automóvel para caminhar. Conforme foi observado no local, elas haviam ido até um pequeno mercado, próximo ao condomínio, no qual se encontraram com as outras pessoas da vizinhança. Ou seja, ainda que não exista espaço adequado para essas atividades e dinâmicas, visto que a forma de construir e habitar o condomínio não as considera como possíveis ou necessárias, elas acontecem

A vida pública e os encontros não apenas ocorrem nos locais onde falta infraestrutura, mas também nos locais em que não se espera que seja possível. A Figura 144 mostra uma família descendo um talude da rodovia SP-332, para atravessá-la. Eles estão saindo de um loteamento residencial, em área urbana dispersa, em direção à outra área de ocupação. Se não fosse por este trajeto, teriam que caminhar até a extremidade da cidade para atravessar a rodovia por uma passarela, ou então caminhar até um viaduto de automóveis, em outra extremidade. As distâncias a serem percorridas são inviáveis a pé, o que demonstra que estes espaços são construídos para os transportes motorizados, desconsiderando a existência de vida pública nos espaços da mobilidade metropolitana.

O reconhecimento da presença dessas dinâmicas no sistema viário metropolitano permite certa aproximação com o cenário urbano. Ainda que essas vias sejam desenhadas e tratadas considerando seu papel na economia global, é importante compreender que parte da população que por ela circula cotidianamente possui dinâmicas locais que encontram lugar no sistema viário metropolitano, apesar de ele ser adverso a estas atividades e à permanência das pessoas.

Na definição sobre as ruas e as especificidades dos projetos e políticas para elas, Gonçalves (2020) elaborou um quadro teórico que aborda as questões e desafios sobre este tema, apresentado a seguir. O quadro (Figura 145) é composto por quatro grandes grupos, pelos quais são apresentados os fatores necessários para a definição de uma rua.

O primeiro grupo considera que a rua é sempre lugar de permanência e mobilidade, passagem e acesso. A ausência de algum desses fatores pode tornar a rua desequilibrada. O segundo grupo mostra sob quais qualidades a mobilidade, a permanência, a passagem e o acesso devem ser analisados. São eles: modais, velocidade, usos e atividades. Essas qualidades definem como podem ser as dinâmicas de cada rua e, também, as formas potenciais de apropriação do espaço.

O terceiro grupo indica duas questões essenciais que determinam as ruas, sua natureza humana, que compreende questões econômicas, sociais e políticas, e sua natureza física, que inclui logística, infraestrutura e ambiental. 
Figura 145: Quadro teórico

\begin{tabular}{|c|c|c|}
\hline \multicolumn{3}{|c|}{ HUMANAS } \\
\hline REGRAS & 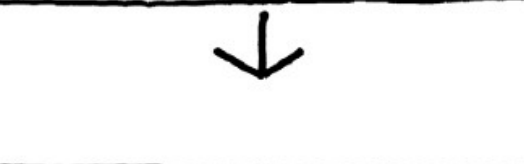 & $K_{\text {PACTOS }}$ \\
\hline$\frac{V_{\text {MODARS }}}{}$ & 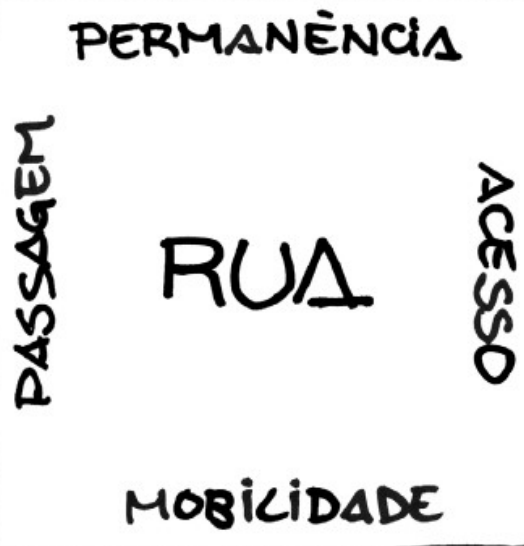 & $\prod_{\text {ATIVIDADES }}^{\text {USOS }}$ \\
\hline $\begin{array}{r}\text { DESENHO } \\
71\end{array}$ & $\uparrow$ & $K^{\text {GESTAOO }}$ \\
\hline LOGISTKCAS & $\begin{array}{l}\text { INTRAESTRUTURAS } \\
\text { FISICAS }\end{array}$ & AMBIENTALS \\
\hline
\end{tabular}

Fonte: Gonçalves, 2020
Essas características se relacionam com o contexto de inserção da rua no sistema, ao mesmo tempo que considera o seu cotidiano e as dinâmicas que nela acontecem ou são passíveis de acontecer. Já o quarto grupo se refere à atuação dos diversos atores sobre o espaço, pela negociação de pactos para a rua, a definição de suas regras, seu desenho e sua gestão.

A análise de todos esses fatores permite conhecer de fato a rua sobre a qual se pretende atuar, reconhecendo suas potencialidades e vocação, ou suas fragilidades. Segundo Gonçalves (2020, p.366)

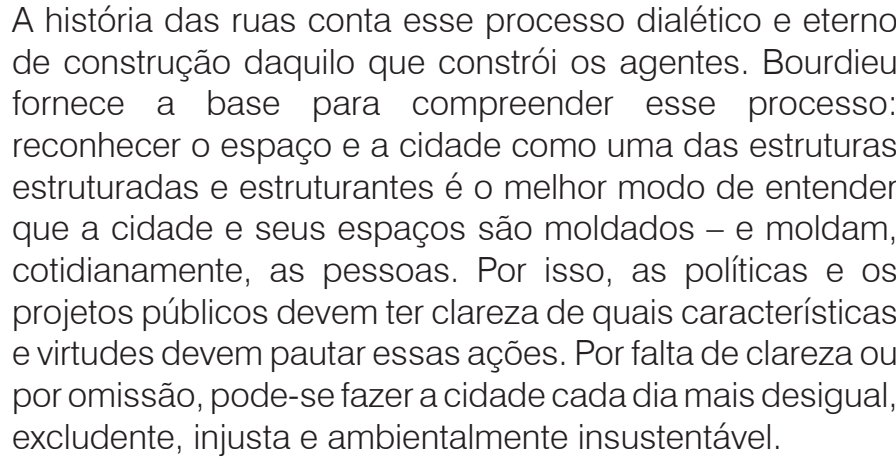

Da mesma forma que as ruas podem ser compreendidas nas suas diversas condições, sendo a forma de atuar sobre elas definida por essa apreensão do seu significado, as vias metropolitanas também devem ser compreendidas na sua complexidade.

A seguir, serão transpostos os elementos apresentados anteriormente, em cada um dos quatro grupos, para as vias metropolitanas que compõem o Vetor 3 da RMC. Desta forma, pretende-se expor quais são as condições sobre as quais o modo de vida metropolitano se organiza, na realização da vida pública

O primeiro aspecto a ser considerado é a "mobilidade". Essa condição é função primordial das vias metropolitanas, que permitem que a mobilidade aconteça nas mais diferentes escalas e pelos mais diversos motivos. Da mesma forma, está a "passagem", que nas vias metropolitanas é considerada pelos órgãos de gestão como a sua principal função. As formas de classificação das vias, tanto de nível de serviço, quanto do CTB ou do SIVIM, demonstram essa condição, visto que instituem que, 
principalmente as vias metropolitanas, que possuem relações em maior escala, não podem ser prejudicadas com a mistura com outras dinâmicas ou velocidades. No entanto, embora os veículos dominem o cenário e os espaços, os outros modos de transporte, os pedestres e ciclistas que por ali circulam diariamente, ainda que não tenham espaços próprios, persistem e disputam os mesmos espaços.

Na categoria "acesso", é possível reconhecer, na caracterização do Capítulo 3, que nas vias metropolitanas os acessos são, na maior parte das vezes, distintos do cenário urbano. Além de alterações nas suas formas, compostas por dispositivos de transição ou vias marginais, as distâncias entre acessos também devem ser consideradas. A densidade de ocupação das áreas de estudo são, geralmente, mais baixas que as das ruas, do espaço intraurbano e, por isso, os acessos estão mais distantes.

Sobre a "permanência", foi demonstrado anteriormente que, ainda que ocorra de forma escassa ou em lugares inesperados, existe vida pública nas vias metropolitanas, que estabelecem relações de vizinhança e comunidade, ainda que não existam espaços específicos para essas dinâmicas.

Do primeiro grupo, portanto, pode-se dizer que existem todos os elementos, no entanto, estão em brutal desequilíbrio, visto que prevalecem a mobilidade e a passagem como fatores principais, com maior incidência nas vias metropolitanas. Os acessos e a permanência estão presentes, mas de forma pouco explícita no território. A dispersão urbana é um dos principais fatores dessa condição, visto que os espaços entre manchas são mais extensos que o espaço urbano, tornando as atividades menos densas, menos concentradas.

Do segundo grupo, que avalia a qualidade das ruas, o primeiro item é a "velocidade". No caso das ruas intraurbanas, este tema é polêmico pela questão da segurança viária dos pedestres que dividem os espaços das ruas com os automóveis. Importante notar que, assim como indica Gonçalves (2020), está em processo de transição o pensamento de que as ruas são feitas para os automóveis, que são, na realidade "os intrusos recém-chegados". Nessas novas abordagens, os pedestres retomam o que thes é de direito, na qualificação das ruas e na definição das suas velocidades.

No caso das vias metropolitanas, que também são compostas e tratadas como rodovias, a velocidade ainda é compreendida como fator essencial na sua conformação e funcionamento. Se a função principal desses elementos é a mobilidade e a passagem, dadas as suas importâncias enquanto elementos estruturadores das dinâmicas regionais, a mais alta velocidade de circulação, ainda que segura, de veículos transportando pessoas ou cargas deve ser priorizada ao máximo. Qualquer interrupção que possa tornar a via ineficiente ou mais lenta prejudica toda a estrutura econômica que define a região metropolitana.

No entanto, como foi demonstrado, essas vias também acomodam atividades de velocidades menores, como é o caso dos pedestres e ciclistas que por ali circulam. Essa mistura de velocidades é um tema não trabalhado na construção das vias metropolitanas, apesar de na realidade já conviverem, de forma desequilibrada.

Outra qualidade da via que deve ser observada são os "modais". Nas vias metropolitanas, também como visto no capítulo anterior, os modais são diversificados, presentes nas suas mais diferentes formas, ainda que nem todos possuam espaço específico para sua circulação. No caso do Vetor 3, é importante destacar não apenas a questão da mobilidade ativa como já apontado, mas o espaço do transporte coletivo público, que se utiliza da mesma infraestrutura dos automóveis e realizando suas paradas em lugares muitas vezes inapropriados e pouco seguros para os usuários.

Propostas que reivindicam que as ruas sejam completas, acomodando igualmente todos os modais ativos ou não, tem sido feitas para as ruas das cidades. Para as vias metropolitanas, no entanto, ao invés de desconsiderar ou proibir, deveriam considerar e valorizar ciclistas, pedestres e o transporte público. 
Em relação aos "usos" lindeiros às vias, pode-se dizer que são semelhantes nas vias metropolitanas e nas ruas, nos espaços intraurbanos. Os usos residenciais, comerciais, de serviços, industriais e até mesmo rurais estão presentes em ambos os cenários e atraem pessoas nas duas situações. É preciso dizer, no entanto, que apesar de os usos serem similares, sua localização no espaço é fundamental para a sua caracterização. As distâncias entre eles e a articulação entre os usos podem alterar de forma significativa a compreensão da via na qual estão inseridos, uma vez que não basta existirem diversos usos por toda a rodovia, mas eles precisam estar combinados de forma a contribuir para a vitalidade da via.

O último elemento de qualificação são as "atividades". No caso das vias metropolitanas, as atividades que acontecem no espaço livre das vias geralmente são cotidianas, impulsionadas pela ocupação do seu entorno, como, por exemplo, o encontro entre pessoas e o descanso nos espaços remanescentes do viário que são atrelados às indústrias. Como demonstrou o estudo, as vias metropolitanas apresentam atividades similares às ruas em contexto urbano, como conversas entre vizinhos, práticas esportivas, crianças brincando ou empinando pipas.

Mesmo manifestações políticas, apesar de mais escassas que nas ruas, acontecem eventualmente nas vias metropolitanas, colaborando na sua definição como espaços de vida pública. Exemplo disso foi a manifestação contra o pedágio da SP-332 ${ }^{1}$, instalado na cidade de Cosmópolis. Um grupo de manifestantes fechou a rodovia em ambos os lados em protesto contra a tarifa, que incide sobre os deslocamentos metropolitanos, que jà se demonstraram imprescindíveis no modo de vida dessa população.

Sobre esse segundo grupo, existe evidente desequilíbrio entre a velocidade praticada pelos veículos e os usos e atividades que ocorrem ao longo das vias. Esse desequilíbrio acontece porque as vias não são construídas de forma a abrigar todos os grupos que dela se utilizam.

Disponível em: https://nogueirense.com.br/manifesto-em-cosmopolis-contrapedagio-interdita-rodovia-sp-332/ Acesso em 15 jan. 2020
Sobre o terceiro grupo, que trata das condições humanas e físicas da via, pode-se dizer que as vias metropolitanas, principalmente as rodovias, são, assim como as ruas, determinadas pelas questões "humanas". No entanto, existe um desequilíbrio entre os fatores econômicos, sociais e políticos, uma vez que nas rodovias, o que tem maior potência são as questões econômicas, que têm como consequências a segregação e a desigualdade dos espaços metropolitanos. Ainda que o espaço de vida das pessoas aconteça sobre essas vias, sua presença é sobreposta pela função pretendida para essas vias, que é a conexão com as dinâmicas regionais e globais

Já em relação às questões "físicas", é possível observar que as vias metropolitanas possuem infraestrutura em abundância, principalmente para que a logística aconteça, dado que o sistema viário é eficiente e articulado. No entanto, percebe-se que há um desequilíbrio na disponibilidade de infraestrutura, já que não considera todas as relações e necessidades das vias, excluindo ou inibindo intencionalmente todas a mobilidade ativa.

Neste descompasso, é possível dizer que o que afasta as rodovias (vias metropolitanas) das ruas, no contexto da RMC, talvez seja, principalmente, o fato de o projeto de vias ser rígido, imutável e os veículos serem privilegiados na estruturação da região metropolitana. A pesquisa Origem-Destino de 2011 mostra a imensa importância do automóvel como principal meio de transporte, mas é preciso reconhecer que as dinâmicas já existentes não se restringem a ele. A pendularidade diversificada, de múltiplos destinos, e a dispersão urbana, características da RMC, são fatores que precisam ser considerados nos planos e projetos para a RMC, uma vez que mostram que o cotidiano da população, o modo de vida metropolitano tem muito mais complexidade do que o movimento pendular da metrópole industrial.

Diante deste cenário, é preciso considerar as questões relativas ao quarto grupo, que trata dos pactos, regras, desenho e gestão das vias. Uma vez que existe um desequilíbrio claro nas características das vias metropolitanas e que, ainda assim, existe um movimento claro de ocupação desse território por uma população que nele não é bem-vinda, é necessário que os pactos 
que se estabelecem sobre o sistema viário metropolitano sejam realizados, uma vez que as condições atuais destas vias não são suficientes para compreender toda a complexidade de dinâmicas que ali acontecem, nem todos os grupos que ali convivem.

Assim, é possível que as regras e lógicas de gestão das vias e suas bordas sejam alteradas e, consequentemente, que o desenho urbano passe a contemplar todas as condicionantes, questões, usos, atividades e usuários já presentes nessas vias. E só assim será possível que a gestão dessas vias aconteça de forma democrática e inclusiva, assim como da região metropolitana como um todo, considerando os modos de vida metropolitanos

A busca por essa compreensão da metrópole passa, portanto, pelo entendimento do seu sistema viário estruturador e das relações que nele acontecem. Ainda que as vias metropolitanas sejam consideradas rodovias ou estradas, a manifestação da vida pública em seu território exige outras classificações. Ao mesmo tempo, não podem ser consideradas ruas, visto que possuem divergências conceituais importantes, seja pela sua inserção em um território de ocupação dispersa, seja pela transescalaridade das suas dinâmicas. Assim, a questão que se coloca diante desse cenário é: O que são, afinal, as vias metropolitanas?

Mas essa busca não se restringe à compreensão do sistema viário em si Assim como aponta Marandola, em trabalho que muito contribuiu para a compreensão das questões aqui tratadas, existe um esforço para o conhecimento da metrópole de forma mais abrangente.

Estamos "em busca do lugar", num esforço de reuni experiências e conhecimentos numa perspectiva que visa a descrever como as pessoas vivem e experienciam metrópole, e como a metrópole vive nas pessoas. Esta é uma forma de tentar conhecer a heterogeneidade, visando a construção de pontes e diálogos, tanto entre os cientistas, quanto entre os lugares, os espaços, os itinerários, as pessoas e os "pedaços" que compõem a metrópole. (MELLO et al., 2004. p.20)
Mais do que a via metropolitana, portanto, vale questionar o que são os espaços nos quais estas vias estão inseridas. A presença da vida pública nestes espaços revela a existência de variados modos de vida metropolitanos que precisam ser considerados no planejamento e no projeto da região metropolitana como um todo. A consideração de um único modo de vida metropolitano confirma a brutal desigualdade no acesso à cidadania plena por boa parte da população residente, usuária e trabalhadora do Vetor 3.

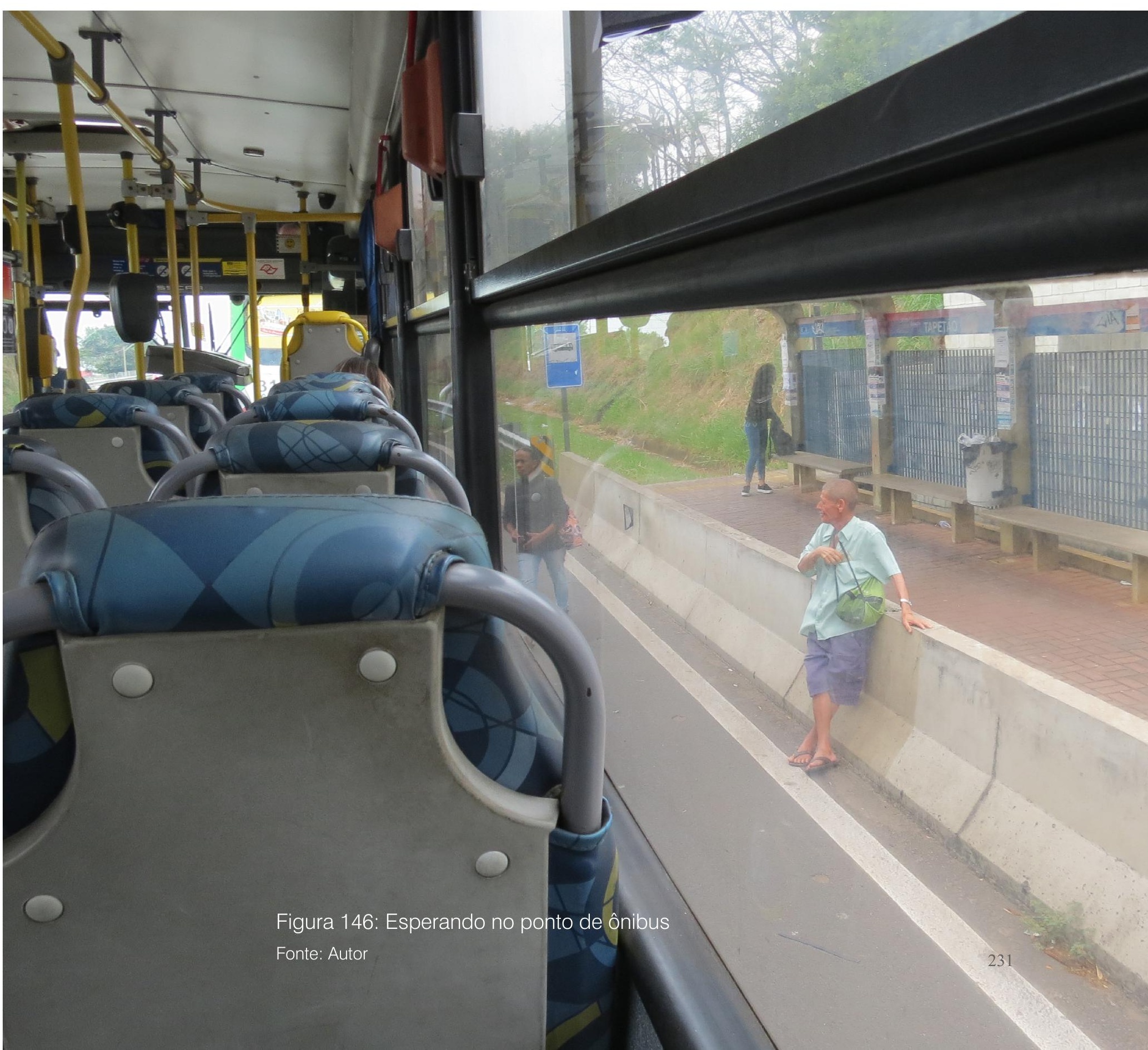




\section{REFERÊNCIAS}

BAENINGER, Rosana Aparecida. Espaço e tempo em Campinas Migrantes e a expansão do polo industrial paulista. 1992. 132 f. Dissertação (Mestrado) - Curso de Sociologia, Instituto de Filosofia e Ciências Humanas, Universidade Estadual de Campinas, Campinas, 1992. Disponível em: http://www.repositorio.unicamp.br/handle/REPOSIP/279107 Acesso em: 04 mar. 2018.

BAENINGER, Rosana Aparecida. A população em movimento. In: FONSECA, Rinaldo B.; DAVANZO, Áurea M. Q.; NEGREIROS, Rovena M. C.. Livro verde: desafios para a gestão da Região Metropolitana de Campinas. Campinas: UNICAMPIIE, 2002. p. 97-134.

BERNARDINI, Sidney Piochi. Regulação às avessas? Uma análise sobre a legislação urbanística instituída nos municípios da Região Metropolitana de Campinas entre 1970 e 2006. Cadernos Metrópole, [s.I.], v. 19, n. 39, p.609-634, ago. 2017. FapUNIFESP (SciELO). DOI: http://dx.doi org/10.1590/2236-9996.2017-3911.

BRASIL. Código de Trânsito Brasileiro: e Legislação Complementar em Vigor. Brasilia: Denatran, 2008. 708 p.

CAIADO, Maria Célia Silva; PIRES, Maria Conceição Silvério. Campinas Metropolitana: transformações na estrutura urbana atual e desafios futuros. In: CUNHA, José Marcos Pinto da. Novas Metrópoles Paulistas População, vulnerabiliade e segregação. Campinas: Nepo/unicamp, 2006. Cap. 10. p. 275-304. 
CAMPINAS. FECAMP - Fundação Economia de Campinas. Secretaria dos Transportes Metropolitanos (STM). Plano Integrado de Transportes Urbanos 2015 (PITU 2015). Campinas, 2006. Disponível em: <http:// uww.stm.sp.gov.br/>. Acesso em: 20 jun. 2019.

CAMPINAS. FUNDAP, Secretaria de Planejamento e Gestão. Plano Estratégico de Desenvolvimento para a Região Metropolitana de Campinas. Campinas, 2010. $259 p$

CENTRO DE ESTUDOS DE DESENVOLVIMENTO ECONÔMICO - CEDE/ IE UNICAMP (Campinas). A Reestruturação Econômico-Espacial e o Futuro da Região Metropolitana de Campinas: Prognósticos, Tendências e Cenários. São Paulo. EMPLASA. Plano e Desenvolvimento Integrado (PDUI) da Região Metropolitana de Campinas, 2018. 212 p. Relatório 3.

COELHO, Leonardo Loyolla. Dispersão, fragmentação e paisagem relações entre dinâmicas naturais e urbanas no vetor oeste da Região Metropolitana de São Paulo. 2015. 300 f. Tese (Doutorado) - Curso de Arquitetura, Faculdade de Arquitetura e Urbanismo, Universidade de São Paulo, Sâo Paulo, 2015

CUNHA, José Marcos Pinto da et al. Expansão metropolitana, mobilidade espacial e segregação nos anos 90: o caso da RM de Campinas. In: CUNHA, José Marcos Pinto da. Novas Metrópoles Paulistas: População vulnerabiliade e segregação. Campinas: Nepo/unicamp, 2006. Cap. 12. p. 337-363.

CUNHA, José Marcos Pinto da; JAKOB, Alberto Augusto Eichman. Análise e diagnóstico sociodemográfico da Região Metropolitana de Campinas. São Paulo. EMPLASA. Plano e Desenvolvimento Integrado (PDUI) da Região Metropolitana de Campinas, 2018a. 97 p. Produto 2.
CUNHA, José Marcos Pinto da; JAKOB, Alberto Augusto Eichman. Cenários prospectivos: uma análise sociodemográfica da Região Metropolitana de Campinas, 2017-2030. In: CAMPINAS. EMPLASA. Plano e Desenvolvimento Integrado (PDUI) da Região Metropolitana de Campinas, 2018b. 44 p. Produto 3.

DAVANZO, Aurea M. Q.; FONSECA, Rinaldo B.; NEGREIROS, Rovena M. C. (Org.). Livro verde: desafios para a gestão da Região Metropolitana de Campinas. Campinas: Unicamp, 2002. 498 p.

EMPRESA METROPOLITANA DE TRANSPORTES URBANOS (EMTU) (São Paulo). Secretaria dos Transportes Metropolitanos. SIVIM 2015. São Paulo, 2006. 140 f. Disponível em: <http://www.emtu.sp.gov.br/ftp/manual_sivim. pdf $>$. Acesso em: 12 jun. 2019

EMPRESA PAULISTA DE PLANEJAMENTO METROPOLITANO SA (EMPLASA). Secretaria dos Transportes Metropolitanos (STM). Governo do Estado de São Paulo. Pesquisa Origem-Destino 2003 da Região Metropolitana de Campinas. São Paulo, 2003

EMPRESA PAULISTA DE PLANEJAMENTO METROPOLITANO SA (EMPLASA). Secretaria dos Transportes Metropolitanos (STM). Governo do Estado de São Paulo. Pesquisa Origem-Destino 2011 da Região Metropolitana de Campinas. São Paulo, 2012.

EMPRESA PAULISTA DE PLANEJAMENTO METROPOLITANO SA (EMPLASA) (São Paulo). Secretaria da Casa Civil do Estado de São Paulo Caderno Preliminar de Propostas. São Paulo: PDUI/RMC, 2018a. 310 p. Relatório 4. Disponível em: <https://www.pdui.sp.gov.br/rmc/>. Acesso em: 12 jun. 2019.

EMPRESA PAULISTA DE PLANEJAMENTO METROPOLITANO SA (EMPLASA) (São Paulo). Secretaria da Casa Civil do Estado de São Paulo Diagnóstico Final dos Problemas Metropolitanos. São Paulo: PDUI/RMC 2018b. 213 p. Relatório 3. Disponível em: <https://www.pdui.sp.gov.br/ rmc/>. Acesso em: 12 jun. 2019. 
EMPRESA PAULISTA DE PLANEJAMENTO METROPOLITANO SA

(EMPLASA) (São Paulo). Secretaria de Estado de Economia e Planejamento.

Relatório de Andamento do Projeto Diagnóstico dos Acidentes de

Trânsito com Vítimas e Relatório Final. São Paulo, 2009. 369 p.

GONÇALVES, Fábio Mariz. Rua, o lugar da vida pública: conceitos especificidades e desafios. 2020. 387 f. Tese (Doutorado) - Curso de Arquitetura e Urbanismo, Faculdade de Arquitetura e Urbanismo, Universidade de São Paulo, São Paulo, 2020.

GONÇALVES, RenatadeP;;BAENINGER, RosanaA. Novas espacialidades no processo de urbanização: a Região Metropolitana de Campinas. 2000. XII Encontro Nacional de Estudos Populacionais. Disponível em: $<$ www.abep.nepo.unicamp.br/docs/anais/pdf/2000/Todos/migt11_3. pdf > . Acesso em: 30 jul. 2019

HAESBAERT, Rogério. O mito da desterritorialização: do "fim dos territórios" à multiterritorialidade. 2. ed. Rio de Janeiro: Bertrand Brasil, 2004

LIMA JR., Orlando Fontes. Aspectos logísticos na Região Metropolitana de Campinas. Cargo News, Campinas, n. 120, p.37-41, 2011. Disponível em $<$ http://www.fec.unicamp.br/ lalt/files/cargo_news/Edicao_120.pdf > Acesso em: 10 nov. 2019

MARANDOLAJr., Eduardo. Habitar em Risco: Mobilidade eVulnerabilidade na experiência metropolitana. 2008. 266 f. Tese (Doutorado) - Curso de Geografia, Universidade Estadual de Campinas, Campinas, 2008

MARANDOLA Jr., Eduardo; GUEDES, Gilvan R.; SILVA, Robson B. da. Perfis de mobilidade nas regiões metropolitanas do interior de São Paulo. Papeles de Población, Toluca, México, v. 16, n. 66, p.177-226, 2010.

MELLO, Leonardo de F., PIRES, Maria C. S., OJIMA, Ricardo, MARANDOLA JR., Eduardo. A busca do lugar: mobilidade e riscos no espaço metropolitano de Campinas. In: Seminário Questão ambiental urbana: experiências e perspectivas, 2004, Brasília. Anais. Brasília: Neur, 2004. p. 1-25.
MIRANDA, Zoraide Amarante Itapura de. A incorporação de áreas rurais as cidades: um estudo de caso sobre Campinas, SP. 2002. 307 f. Dissertação (Mestrado) - Curso de Economia Aplicada, Universidade Estadual de Campinas, Sao Paulo, 2002

NASCIMENTO, Ederson. As desigualdades socioespaciais urbanas numa metrópole interiorana: uma análise da Região Metropolitana de Campinas (SP) a partir de indicadores de exclusão/inclusão social. 2013 243 f. Tese (Doutorado) - Curso de Geografia, Instituto de Geociências, Universidade Estadual de Campinas, Campinas, 2013

NASCIMENTO, Ederson. Região Metropolitana de Campinas (SP): Cinco décadas de expansão urbana. Boletim Campineiro de Geografia Campinas, v. 6, n. 1, p.67-91, 2016.

PASQUOTTO, Geise Brizottietal. TransportePúblico da Região Metropolitana de Campinas. In: SIMPÓSIO BRASILEIRO ONLINE DE GESTÃO URBANA 2., 2018, Brasil. Anais, 2018. v. 1, p. 458 - 472. Disponível em: <http:// portalcampinasinovadora.com.br/wp-content/uploads/2019/01/50_Artigocompleto-em-evento_2018_II-SIBOGU.pdf > . Acesso em: 17 nov. 2019.

PIRES, Maria Conceição Silvério. Morar na metrópole: expansão urbana e mercado imobiliário na Região Metropolitana de Campinas. 2007. 178 f. Tese (Doutorado) - Curso de Geografia, Instituto de Geociências, Universidade Estadual de Campinas, Campinas, 2007

QUEIROGA, Eugenio Fernandes. Dimensões Públicas do Espaço Contemporâneo: resistências e transformações de territórios, paisagens e lugares urbanos brasileiros.. São Paulo Sp: Tese(livre Docência) - Fauusp, 2012 
QUEIROGA, Eugenio Fernandes; BENFATTI, Denio Munia. Entre o nó e a rede, dialéticas espaciais contemporâneas: o caso da metrópole de Campinas diante da megalópole do Sudeste do Brasil. Revista Brasileira de Estudos Urbanos e Regionais, [s.I.], v. 9, n. 1, p.41-52, 31 maio 2007. Revista Brasileira de Estudos Urbanos e Regionais (RBEUR). http://dx.doi. org/10.22296/2317-1529.2007v9n1p41.

REIS, Nestor Goulart. Notas sobre urbanização dispersa e novas formas de tecido urbano. São Paulo: Via das Artes, 2006. 201 p

SANTOS, Milton (Org.). A natureza do Espaço: Técnica e Tempo. Razão e Emoção. 2. ed. São Paulo: Editora da Universidade de São Paulo, 2006. $259 \mathrm{p}$.

SANTOS, Milton. A urbanização Brasileira. 2. ed. São Paulo: Hucitec, 1993.

Setti, José Reynaldo. Highway Capacity Manual ou Manual de Capacidade Viária? Anais do $6^{\circ}$ Congresso Brasileiro de Rodovias e Concessões - CBR\&C 2009, Florianópolis, SC.

SOBREIRA, Daniel Pessini. A metrópole e seus deslocamentos populacionais cotidianos: O caso do deslocamento pendular na Região Metropolitana de Campinas. 2007. 98 f. Dissertação (Mestrado) - Curso de Demografia, Departamento de Demografia do Instituto de Filosofia e Ciências Humanas, Universidade Estadual de Campinas, Campinas, 2007.

TAVARES, Jeferson Cristiano. Planejamento Regional no Estado de São Paulo: Polos, Eixos e a Região dos Vetores Produtivos. Revista Brasileira de Estudos Brasileiros Regionais, São Carlos, v. 20, n. 2, p.344-367, ago. 2018 .

TRB (2000) Highway Capacity Manual, Transportation Research Board National Research Council, Washington, D.C., EUA. Disponível em: http:// www.trb.org/Publications/hcm6e.aspx. Acesso em: 15 out. 2019.
VILLAÇA, Flávio. Espaço Intra-urbano no Brasil. 2 edição São Paulo: Studio Nobel: Fapesp, 2001. 373 p.

YUASSA, Vanessa Naomi. Impacto na hierarquia viária orientada para o automóvel no nível de serviços de modos não motorizados. 2008 202 f. Dissertação (Mestrado) - Curso de Engenharia Civil, Escola de Engenharia de São Carlos, Universidade de São Paulo, São Carlos, 2008. 
